UNIVERSIDADE DE SÃO PAULO

INSTITUTO DE BIOCIÊNCIAS

JOÃO PAULO DI MONACO DURBANO

Investigação de concepções de alunos de ciências biológicas do IB/USP acerca da

Natureza da Ciência 


\section{Investigação de concepções de alunos de ciências biológicas do IB/USP acerca da Natureza da Ciência}

Dissertação de Mestrado do Programa de PósGraduação em Ciências Biológicas (Biologia/Genética) do Instituto de Biociências da Universidade de São Paulo, área de concentração Estratégias de Ensino e Aprendizado em Biologia, sob orientação da Profa. Dra. Maria Elice Brzezinski Prestes. 
Nome: João Paulo Di Monaco Durbano

Título: Investigação de concepções de alunos de ciências biológicas do IB/USP acerca da Natureza da Ciência

Dissertação de Mestrado do Programa de Pós-

Graduação em Ciências Biológicas (Biologia/Genética) do Instituto de Biociências da Universidade de São Paulo, área de concentração Estratégias de Ensino e Aprendizado em Biologia, sob orientação da Profa. Dra. Maria Elice Brzezinski Prestes.

Banca realizada em:

Banca Examinadora 
À minha espasa e ass meus pais, com amor, admiraçãa e gratidãa par toda compreensãa, carinha, presenca e incansável apoia aa longa do periada de elabaraçãa deste trabalho. 


\section{Agradecimentos}

Agradeço à minha esposa Ana e aos meus pais, as pessoas que mais amo, que sempre me apoiaram em todos os momentos com amor e carinho, são presenças indissociáveis da minha vida e fontes de motivação e inspiração em tudo o que faço.

Aos meus irmãos Pedro Henrique e Carlos Eduardo por tudo que aprendi com vocês, mesmo que não saibam disso.

À Maria Elice, não somente pela orientação nesta dissertação, como também pelos ensinamentos, carinho e dedicação ao longo dos últimos anos. Declaro minha admiração pela profissional dedicada e pela orientação que me deu, estando sempre presente e, ao mesmo tempo, prezando pela minha autonomia, uma mãezona.

A toda minha família, especialmente aos meus primos Edson Renato, Luciana Durbano, Júlia dos Santos e Lucas Durbano, pelo carinho, atenção, parceria e pelo apoio que me deram durante esses últimos anos.

Aos meus amigos, e colegas de pesquisa do grupo Seminários de História da Biologia no Ensino: Eduardo de Carvalho, Fabrício Bittencourt, Tatiana Tavares, Alan Dantas, José Monte Sião, Marcelo Gilge, Gerda Maisa Jensen, Rosa Andrea de Souza, Miler Pereira e Luciana Nogueira pela paciência, críticas e sugestões à pesquisa e pelos bons momentos que passamos juntos.

Ao Prof. Dr. Rui Murieta pelos conselhos, críticas e pelas sugestões ao aprimoramento metodológico da parte empírica deste trabalho, assim como aos demais membros da banca de qualificação, Profa. Dra. Eliana Dessen e Profa. Dra. Suzana Ursi.

Ao Prof. Dr. Paulo Sano pelas oportunidades e ensinamentos;

À Profa. Dra. Jesuina Pacca e ao Prof. Dr. Hamilton Haddad que ministraram disciplinas que foram importantíssimas para o desenvolvimento da pesquisa.

À Profa. Dra. Regina Celia Mingroni Netto e à Deisy Santos de Morais pela atenção a ajuda, todas as vezes que necessitei saber informações sobre $o$ programa de Pós-Graduação. 
Aos pareceristas de eventos e revistas, que deram sugestões e criticaram os trabalhos enviados, e, dessa forma, foram importantíssimos para o direcionamento da pesquisa.

À Capes pelo auxílio que possibilitou dedicação à pesquisa.

$A$ todos os meus amigos que direta ou indiretamente me apoiaram e que estiveram presentes em muitas etapas da construção não apenas deste trabalho, mas de tudo que sou hoje. 
A imaginacãa é mais impartante da que a canhecimenta.

Albert Einstein 


\section{RESUMO}

Esta pesquisa objetivou levantar concepções de estudantes de Ciências Biológicas sobre a Natureza da Ciência (NdC). Para isso foram utilizados os questionários VNOS-C, desenvolvido por Norman Lederman, Fouad Abd-ElKhalick, Randy Bell e Reneé S. Schwartz, em 2002, e o questionário VOSE, desenvolvido por Sufen Chen, em 2006. Os dois questionários foram aplicados em alunos ingressantes do Curso de Ciências Biológicas do Instituto de Biociências da Universidade de São Paulo em duas etapas, no início e final do primeiro semestre letivo. A fim de complementar os dados fornecidos a partir da aplicação dos questionários VNOS-C e VOSE, foi realizada uma triangulação de metodológica e de dados, onde buscamos: a partir do Questionário Sociocultural e de Opinião Sobre a Importância da NdC, traçar o perfil sociocultural e de opinião dos alunos a respeito das questões investigadas, e, a partir de entrevistas semiestruturadas com professores dos alunos investigados, conhecer possíveis abordagens, em sala de aula, sobre questões da NdC. Para a análise escolhemos alguns aspectos da NdC a saber: a criatividade e imaginação na construção do conhecimento científico, a inserção da ciência na cultura, o papel das teorias na construção do conhecimento científico, a diferença entre leis e teorias científicas e o caráter provisório do conhecimento científico. No questionário de opinião aplicado ao final do semestre os alunos declararam ter lembrado de alguns desses aspectos, que teriam sido abordados nas disciplinas cursadas. Os professores, durante as entrevistas, também declararam ter trabalhado alguns aspectos da $\mathrm{NdC}$ em sala de aula. Os resultados dos questionários VNOS-C e VOSE mostraram que foi possível observar mudanças nas respostas dos alunos apenas para alguns dos aspectos investigados. Acreditamos que a pesquisa fornece alguns elementos que podem alertar para a necessidade de que sejam desenvolvidas abordagens e temáticas explícitas de ensino sobre a ciência.

Palavras-chave: Natureza da Ciência, questionários VNOS-C e VOSE, concepções de estudantes sobre ciência. 


\begin{abstract}
The objective of this research was to raise conceptions about Nature of Science (NOS) from Biological Sciences students. For this purpouse we utilized the VNOS-C questionnaire, developed by Norman Lederman, Fouad Abd-ElKhalick, Randy Bell and Renee S. Schwartz, in 2002, and VOSE questionnaire, developed by Chen Sufen in 2006. These questionnaires were applied to freshman students of at the University of São Paulo School of Biological Sciences in two stages, at the beginning and at the end of the first semester. To complement the data provided from the VNOS-C and VOSE questionnaires, we performed a methodological and data triangulation, where we seek, from a Sociocultural and Opinative About the Importance of NOS Questionnaire, to make a student' profile about sociocultural and opinative related to the issues investigated; and from semi-structured interviews with these students' teachers, to achieve possible approaches issues of NOS, for the classroom. For the analysis we chose some aspects of NOS namely: creativity and imagination in the construction of scientific knowledge, the inclusion of science in culture, the role of theories in the construction of scientific knowledge, the difference between scientific theories and laws and the provisional nature of knowledge scientific. In the opinion questionnaire applied to the end of the semester students reported having remembered some of these aspects, which would have been covered in the courses taken. Teachers, during interviews, also claimed to have worked some aspects of the NOS in the classroom. The results of the VNOS-C and VOSE questionnaires showed that it was possible to observe changes in students' answers to only some of the aspects investigated. We believe this research provides some evidence that could warn about the need of the development of explicit teaching thematics and approaches about science.
\end{abstract}

Keywords: Nature of Science, VNOS-C and VOSE questionnaires, conceptions of students about science. 


\section{LISTA DE TABELAS}

Tabela 1 - Quadro representativo da organização das transcrições

Tabela 2 - Aspectos da NdC investigados e as questões dos questionários VNOS-C e VOSE utilizadas

Tabela 3 - Idade média e desvio-padrão das idades dos alunos

Tabela 4 - Nível de formação e participação na renda familiar dos alunos investigados

Tabela 5 - Tempos de resposta

Tabela 6 - Quantidade de alunos que lembraram das questões durante o semestre

Tabela 7 - Aspectos da NdC que foram lembrados pelos alunos

Tabela 8 - Análise quantitativa das respostas à questão 8 do questionário sociocultural

Tabela 9 - Análise qualitativa das respostas à questão 8 do questionário sociocultural

Tabela 10 - Dimensões e categorias obtidas a partir das respostas à pergunta número 10 do VNOS-C na primeira etapa de aplicação do questionário

Tabela 11 - Dimensões e categorias obtidas a partir das respostas à pergunta número 10 do VNOS-C na segunda etapa de aplicação do questionário

Tabela 12 - Ranking médio das respostas de cada um dos itens da questão 3 do VOSE

Tabela 13 - Dimensões e categorias obtidas a partir das respostas à pergunta número 11 do VNOS-C na primeira etapa de aplicação do questionário

Tabela 14 - Dimensões e categorias obtidas a partir das respostas à pergunta número 11 do VNOS-C na segunda etapa de aplicação do questionário

Tabela 15 - Ranking médio das respostas de cada um dos itens da questão 2 do VOSE

Tabela 16 - Dimensões e categorias obtidas a partir das respostas à pergunta número 9 do VNOS-C na primeira etapa de 
aplicação do questionário

Tabela 17 - Dimensões e categorias obtidas a partir das respostas à pergunta número 9 do VNOS-C na segunda etapa de aplicação do questionário

Tabela 18 - Ranking Médio das respostas aos itens 8A, 8C, 15D, $15 \mathrm{E}, 15 \mathrm{H}, 15 \mathrm{I}$ do VOSE

Tabela 19 - Dimensões e categorias obtidas a partir das respostas à pergunta número 6 do VNOS-C na primeira etapa de 68 aplicação do questionário

Tabela 20 - Dimensões e categorias obtidas a partir das respostas à pergunta número 6 do VNOS-C na segunda etapa de aplicação do questionário

Tabela 21 - Ranking médio das respostas de cada um dos itens da questão 7 do VOSE

Tabela 22 - Categorias obtidas a partir das respostas dos alunos à pergunta número 7 do VNOS-C na primeira etapa de aplicação do questionário

Tabela 23 - Categorias obtidas a partir das respostas dos alunos à pergunta número 7 do VNOS-C na segunda etapa de aplicação do questionário

Tabela 24 - Ranking médio das respostas de cada um dos itens da questão 4 do VOSE 


\section{SUMÁRIO}

Banca Examinadora i

Dedicatória ii

Agradecimentos iii

Epígrafe v v v v vas

Resumo vi

Abstract vii

Lista de tabelas viii

Sumário $\quad x$

INTRODUÇÃO

1 A NATUREZA DA CIÊNCIA NO ENSINO 6

1.1 Delimitando a concepção de NdC no ensino 7

1.2 Concepções de ciência da filosofia da ciência do século 14
$X X$

1.3 Instrumentos de coleta de dados para investigação de noções de estudantes sobre $\mathrm{NdC}$

2 PLANEJAMENTO DA PESQUISA

2.1 O contexto da pesquisa: o curso de Ciências Biológicas do IB-USP

2.1.1 Amostra 29

2.2 Triangulação 31

2.2.1 Triangulação de dados 32

2.2.1.1 Alunos 32

2.1.1.2 Professores $\quad 32$

2.2.2 Triangulação metodológica 33

2.2.2.1 Questionário Sociocultural e de Opinião Sobre a Importância da NdC

2.2.2.2 Entrevistas

2.2.2.3 Questionários para coleta de dados acerca da NdC: VNOS-C e VOSE

2.3.1 Análise do questionário Sociocultural e de Opinião Sobre a Importância da NdC

2.3.2 Análise das entrevistas com os professores

2.3.3 Análise dos questionários para coleta de dados 
acerca da NdC: VNOS-C e VOSE

2.3.4 Parâmetros teóricos para análise das respostas $\quad 40$

3 RESULTADOS E DISCUSSÃO

3.1 Aplicação dos questionários: perfil dos participantes e 44 tempos de resposta

3.2 Opinião dos alunos sobre as questões da pesquisa $\quad 46$

3.3 Entrevistas semiestruturada com professores 49

3.4 Investigação das respostas dos alunos - questionários VNOS-C e VOSE

3.4.1 A Criatividade e imaginação na construção do conhecimento científico

3.4.2 O conhecimento científico está inserido na cultura

3.4.3 O conhecimento científico é determinado por teorias

3.4.4 Leis e teorias científicas

3.4.5 O conhecimento científico é provisório 73

4 CONCLUSÕES

REFERÊNCIAS BIBLIOGRÁFICAS 83

ANEXOS 90

Anexo 1: Termo de Consentimento Livre e Esclarecido $\quad 91$

Anexo 2: Conteúdos descritos nas ementas das disciplinas $\quad 92$

Anexo 3: Questionário Sociocultural e de Opinião Sobre a Importância da NdC

94

Anexo 4: Transcrição das entrevistas com os professores $\quad 95$

Anexo 5: Questionário VNOS-C 146

Anexo 6: Questionário VOSE $\quad 149$

Anexo 7: Transcrição das respostas dos alunos - 156 questionário VNOS-C

Anexo 8: Tabulação das respostas dos alunos - questionário VOSE 


\section{INTRODUÇÃO}

Mesmo que a Filosofia da Ciência, ao longo do século XX, apresente divergências importantes sobre o modo como compreendemos a construção do conhecimento científico, as discussões sobre as características da ciência dizem respeito a particularidades filosóficas que podem ser deixadas em segundo plano quando se tem em conta o contexto do ensino de ciências. No âmbito do ensino, algumas características menos polêmicas da ciência parecem ser suficientes para auxiliar a compreensão da racionalidade científica e o modo pelo qual o conhecimento científico é produzido.

Essas características passaram a ser traduzidas pela literatura de ensino de ciências das duas últimas décadas pela expressão "Natureza da Ciência" (NdC). Nesse âmbito, este construto "Natureza da Ciência" tem sido usado para referir-se não a ciência em sentido amplo, mas, mais especificamente, às características do conhecimento científico e ao modo pelo qual ele é produzido (Grotzer, Miller, Lincoln, 2012, p. 41).

Proporcionar ao aluno uma compreensão de como o conhecimento científico é construído envolve uma discussão histórica e contextualizada. Essa discussão auxilia na compreensão da complexidade da construção dos conhecimentos científicos e sua problematização, a fim de tornar os estudantes mais conscientes do mundo em que vivem e aptos a compreendê-lo (Scheid, Ferrari, Delizoicov, 2007, p. 158).

Discutir a racionalidade científica nas aulas de ciências não é uma novidade. No século XIX, figuras centrais da filosofia e da própria investigação científica já anunciavam os benefícios da introdução da filosofia e da história da ciência nos programas e currículos de ciência. Entre outros, essa proposta foi defendida por William Whewell (1794-1866), Thomas Huxley (1825-1895) e Ernst Mach (1838-1916). No início do século XX, a importância dessa abordagem para estudantes de ciências foi reforçada (Lederman, 2007, p. 831). Apareceu, por exemplo, em artigo de John Dewey (1859-1952) com o título "Science as subject-matter and as method" (Ciência como tema e como método), publicado na Science, em 1910. Entre as décadas de 1940 e 1970, outros trabalhos retomaram o tema, como o artigo de Joseph Schwab, "The 
nature of scientific knowledge as related to liberal education" (A natureza do conhecimento científico e sua relação com a educação liberal), de 1949, capítulos de Gerald Holton intitulados "Science, science teaching and rationality" (Ciência, educação científica e racionalidade), de 1975, e "On the educational philosophy of the Project physics course" (Sobre a filosofia educacional do projeto curso de física), de 1978, entre outros (Matthews, 2012, p. 3).

Nas últimas três décadas, no entanto, a abordagem em sala de aula de aspectos que ultrapassam os produtos da ciência e explicitam aspectos metacientíficos foi tornada norteadora não apenas da prática docente reflexiva (Oki, 2008, p. 70), como fomentou o crescimento de uma linha de pesquisa própria em cursos de pós-graduação de ensino de ciências, no Brasil e no exterior. Diversos autores contribuíram para isso, dentre os quais podem ser citados alguns mais expoentes tais como Derek Hodson, Richard Duschl e Michael Mattews (Matthews, 2012, p. 3). Este último é o líder do grupo mais representativo da área, The International History, Philosophy and Science Teaching Group, que desde 1989 organiza conferências bianuais gerais, alternadas com encontros regionais ou temáticos, como $01^{\text {st }}$ Latin American Conference of the International History, Philosophy, and Science Teaching Group (IHPST-LA), em Maresias, São Paulo, de 12 a 14 de agosto de 2010 (Silva \& Prestes, 2012). O grupo está associado ao periódico Science \& Education responsável pelo fortalecimento dessa tradição de pesquisa.

No Brasil, entre os pioneiros a discutir o uso da história e filosofia da ciência no ensino estão Mario Schemberg (na física), Antonio Brito da Cunha (na biologia), Leopoldo Nachbin (na matemática) e Simão Mathias (na Química). Nos anos 1970 e 1980, alguns autores iniciaram a produção de material didático contendo aspectos históricos e filosóficos, tais como Amélia Império Hamburger, João Zanetic, Ernest Hamburger, Alberto Vilani (Martins, Prestes e Silva, no prelo).

$\mathrm{Na}$ área de ensino de biologia, Myriam Krasilchik coordenou, nos anos de 1970, uma coleção de kits didáticos de experimentos, chamada "Os cientistas", pautados sobre os grandes personagens da história da ciência. Além de seu interesse em promover o uso da história e da filosofia no ensino de biologia, Krasilchik foi a principal responsável pelo estabelecimento da área 
de pesquisa em nosso país. Promoveu por cerca de 20 anos os eventos Encontro Perspectivas do Ensino de Biologia (EPEB) na Faculdade de Educação da USP, que deram origem à criação da Sociedade Brasileira para o Ensino de Biologia (SBEnBio) e seus encontros nacionais e regionais. Nesses eventos ocorreu um crescente interesse pelo desenvolvimento de linhas de pesquisa que vinculam a história e filosofia da biologia ao ensino dessa disciplina.

Nos anos 1990, começou a se formar no país uma comunidade de pesquisadores voltados especialmente a essa interface, dentre os quais podese mencionar Lilian Al-Chueyr Pereira Martins (1998), Nelio Bizzo (Bizzo; ElHani, 2004) e Charbel El-Hani (2004). Em 2006, foi criada a Associação Brasileira de Filosofia e História da Biologia que também promove o uso de episódios da história e da filosofia da biologia por meio de artigos de pesquisa e traduções de fontes primárias divulgados em suas publicações, o Boletim de História e Filosofia da Biologia e o periódico Filosofia e História da Biologia. A publicação de traduções de trechos de obras importantes da história da biologia objetiva a disponibilização de um acervo de material instrucional para ser usado por professores da escola básica e superior.

Em sintonia com essa tendência, que vem sendo designada mais recentemente como ensino contextual das ciências, foi implementado em 2007 - Projeto Pedagógico do curso de Ciências Biológicas do Instituto de Biociências da Universidade de São Paulo (IB-USP). A estrutura curricular planejada e estabelecida por esse projeto visa a "formação sólida, ampla e histórica dos conceitos, princípios e teorias da Biologia", associada à preocupação de abordar os conhecimentos biológicos de modo não dissociado "das questões sociais, políticas, econômicas e culturais" (IB-USP, 2007, p. 1). $O$ documento explicita ainda entre os objetivos gerais do curso o de formar um aluno possa estabelecer relações entre ciência, tecnologia e sociedade e atender ao mercado de trabalho com visão ética e humanista ( $I d$.).

Embora não sejam sempre retomados e valorizados como deveriam, os projetos políticos pedagógicos de cada unidade escolar são balizas que deveriam nortear todo o sistema de avaliação de seus cursos. Como orienta Luckesi: 
O ponto de partida para atuar com avaliação é saber o que se quer com a ação pedagógica. A concepção pedagógica guia todas as ações do educador. O ponto de partida é saber aonde desejamos chegar em termos da formação do educando. Afinal, que resultados desejamos? Ou seja, precisamos definir com clareza o que queremos, a fim de produzir, acompanhar (investigar, e interferir, se necessário) para chegar aos resultados almejados. O Projeto-Político-Pedagógico configura tanto a direção da prática educativa como os critérios da avaliação. Oferece a direção para a ação pedagógica e, ao mesmo tempo, é guia e critério para a avaliação. (Luckesi, 2011, p. 27)

O Projeto Pedagógico do curso de Ciências Biológicas do Instituto de Biociências da Universidade de São Paulo (IB-USP) tem a preocupação de capacitar o graduando a desenvolver ações estratégicas, diagnosticar e resolver problemas, elaborar e executar projetos relacionados à sua área de formação (IB-USP, 2011). Um dos fatores necessários para essa formação nas Ciências Biológicas envolve o conhecimento sobre a NdC.

Tendo em vista o breve histórico que contextualiza o surgimento de projetos pedagógicos como esse, a presente pesquisa teve o objetivo de investigar as concepções de Natureza da Ciência dos estudantes do curso de graduação em Ciências Biológicas do IB-USP, antes e depois de cursarem o primeiro semestre letivo. A questão de pesquisa era buscar avaliar se as disciplinas do primeiro semestre promovem alterações nas concepções dos alunos sobre a Natureza da Ciência. Os resultados obtidos podem fornecer subsídios para o planejamento de ações educativas que levem a otimizar o ensino contextualizado da ciência, conforme preconizado no Projeto Pedagógico do curso de Ciências Biológicas do IB/USP.

Esta dissertação divide-se em quatro capítulos. O capítulo 1 corresponde à contextualização do estudo, em que são retomadas justificativas que apontam a sua relevância. No primeiro momento, são discutidas as características da ciência apontadas na literatura especializada como sendo as de maior relevância a serem tratadas no ensino. Em seguida, são sumarizadas as discussões da filosofia da ciência ao longo do século XX, indicando algumas dentre as principais vertentes que definem o conhecimento científico. Esse referencial teórico serviu de base ao planejamento da pesquisa e norteou a 
análise dos resultados obtidos. No terceiro momento do capítulo 1, é apresentada uma discussão sobre os questionários propostos na literatura de ensino de ciências para o levantamento de concepções de Natureza da Ciência entre estudantes dos diversos níveis de ensino, de professores em formação e em serviço, indicando os critérios de escolha dos instrumentos adotados na presente pesquisa.

O capítulo 2 apresenta os procedimentos da pesquisa baseados em triangulação de dados e triangulação metodológica, conforme proposto por Norman Denzin (1988, p. 319). A triangulação de dados refere-se à utilização de duas fontes de dados, neste caso, os professores das disciplinas do primeiro semestre do curso e os alunos matriculados. A triangulação metodológica caracteriza-se pela coleta de dados por meio de diferentes instrumentos de pesquisa.

Neste trabalho, foram utilizados três instrumentos para coletar dados junto aos alunos. Dois deles para investigação de concepções sobre a NdC: 0 questionário VNOS-C, desenvolvido por Norman Lederman, Fouad Abd-ElKhalick, Randy Bell e Reneé S. Schwartz, em 2002 e o questionário VOSE, desenvolvido por Sufen Chen, em 2006. O terceiro instrumento foi desenvolvido nesta pesquisa e serviu para levantar dados socioculturais dos alunos. Para a coleta de dados junto aos professores optou-se pela realização de entrevistas semiestruturadas.

O capítulo 3 da dissertação apresenta os resultados e as discussões geradas a partir da análise dos questionários aplicados junto aos alunos e das entrevistas realizadas com os professores.

Por fim, o capítulo 4 apresenta as conclusões do estudo, estabelecidas a partir das triangulações realizadas, além de ponderações sobre pesquisas futuras na área. Após as referências bibliográficas, estão presentes anexos referentes à documentação utilizada na pesquisa. 


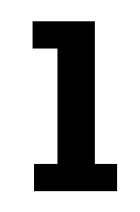

NATUREZA DA CIÊNCIA NO ENSINO 


\subsection{Delimitando a concepção de NdC no ensino}

O ensino de ciências deve proporcionar ao estudante uma atitude reflexiva e crítica, de forma que o aluno conheça, não apenas os conteúdos científicos, mas também seus pressupostos, sua validade e influências contextuais (Forato, 2009). Esse conhecimento contextualizado da ciência, partindo de uma discussão sobre a construção do conhecimento científico e sua relação com a sociedade e a cultura, proporciona um conhecimento mais amplo dos conteúdos e processos da ciência (Reis, 2004, p. 6).

Uma aprendizagem da ciência acompanhada por uma aprendizagem sobre a ciência é item priorizado atualmente entre pesquisadores da área da educação científica. O modelo preconizado hoje para a formação em ciências leva em conta que, quando chamados a opinar a respeito das diversas questões cotidianas que envolvem a ciência, os estudantes e futuros cidadãos necessitam compreender a natureza do saber científico (Santos, 2004, p. 83). Esse interesse, em formar com vistas a um conhecimento contextualizado da ciência, está relacionado ao que afirmam David Reid e Derek Hodson (1993) quando dizem que uma educação dirigida para uma cultura científica básica deve dar atenção à melhora no tratamento das questões filosóficas, históricas e sociais, questões relacionadas à natureza do desenvolvimento e conhecimento científico.

A literatura de ensino de ciências vem discutindo variadas justificativas para a exploração de NdC no ensino: a necessidade de manipulação e de entendimento da tecnologia; a compreensão da ciência como produto cultural; o sucesso no aprendizado de conteúdos da ciência; a satisfação em estudar a ciência, entre outros (Ferreira, 2009). Talvez a forma mais concisa de atender a questão do por que o entendimento sobre a NdC é importante, é retomar os cinco argumentos fornecidos por Rosalind Driver, John Leach, Robin Millar e Philip Scott (1996), destacados também por Lederman (2007). Segundo Driver e seus colaboradores, o entendimento sobre $\mathrm{NdC}$ é necessário segundo as perspectivas:

- Utilitarista: para a ciência fazer sentido e para habilitar ao gerenciamento dos objetos e processos tecnológicos na vida cotidiana. 
- Democrática: para a tomada de decisões esclarecidas sobre questões sócio científicas.

- Cultural: para apreciar o valor da ciência como parte da cultura contemporânea.

- Moral: para desenvolver uma compreensão das normas da comunidade científica que incorporam os compromissos morais que são de interesse geral e valor para a sociedade.

- Econômica: para qualificar os cientistas a fim de manterem e desenvolverem o processo industrial, do qual a prosperidade nacional depende. (Driver, Leach, Millar e Scott, 1996, p. 23)

Essas são algumas das justificativas apresentadas na literatura para que os professores de ciências ocupem suas aulas não apenas com os conteúdos científicos, mas também com conteúdos metacientíficos - mesmo havendo divergências no âmbito da História, Filosofia e Sociologia da Ciência em relação à própria definição do construto NdC (Alters, 1997) e do próprio entendimento de o que é ciência. Na seção seguinte deste capítulo, apresentaremos um breve apanhado dessas divergências ao longo do século XX. Porém, a ausência de uma única definição não deve causar surpresa, considerando-se o caráter complexo e dinâmico que caracteriza a atividade científica (Acevedo e col., 2005).

Nesta pesquisa adotamos a perspectiva defendida por Lederman (2007) de que no âmbito do ensino as divergências epistêmicas sobre o que vem a ser a ciência e o que deveria compor os principais aspectos da NdC são menos relevantes do que para os filósofos da ciência. Acreditamos que as divergências podem ceder lugar à adoção de um conjunto de características mais consensualmente aceitas e assumidas mediante um posicionamento político sobre o que esperamos e preconizamos para o ensino de ciências.

A discussão mais interessante e promissora nos estudos recentes sobre $\mathrm{NdC}$ tem-se centrado exatamente em quais características sobre a ciência são as mais adequadas e devem ser privilegiadas no currículo de ciências no Ensino Básico e Superior (Paraskevopoulou e Koliopoulos, 2011, p. 944).

Em um de seus artigos, Fouad Abd-El-Khalick e Norman Lederman (2000) apresentam um breve histórico das mudanças que caracterizaram a 
definição do construto $\mathrm{NdC}$ ao longo do século XX. Segundo os autores, na primeira metade do século, a visão de ciência era praticamente equivalente à compreensão de "método científico" e, nos anos 1960, era permeada ainda por grande ênfase nas etapas da investigação científica, como a observação, o levantamento de hipóteses, o planejamento de experimentos e a inferência e interpretação de dados.

$\mathrm{Na}$ década de 1970, as discussões migraram para outro foco de interesse, conforme ilustrado em documentos como "Center of Unified Science Education at Ohio State University" (Centro de Educação Científica Unificada da Universidade do Estado de Ohio). A ciência é caracterizada ali como provisória ou sujeita a mudanças, pública, replicável, que reflete tentativas humanas de explicar a natureza, que possui seu próprio conjunto de regras e valores e que possui um forte componente empírico, ou seja, que é baseada e/ou derivada de observações do mundo natural (Adb-El-Khalick; Lederman, 2000, p. 667).

Na década de 1980, nova mudança ocorre e fatores psicológicos (como o papel da criatividade humana na ciência) e sociológicos (como a estrutura e dinâmica das relações interpessoais nas organizações científicas) começaram a aparecer nas definições da NdC.

Em 1990, o "California Department of Education" (Departamento de Educação da Califórnia) enfatizou o papel norteador que as teorias desempenham nas atividades científicas, ressaltando que os cientistas realizam suas investigações a partir de referenciais teóricos determinados (Adb-El-Khalick e Lederman, 2000, p. 668).

Documentos oficiais de ensino nos Estados Unidos, também refletiram essas preocupações, como o "Science for All Americans" (Ciência para todos os americanos), de 1990. Encontra-se ali que a ciência não pode fornecer respostas a todas as perguntas; envolve a imaginação e invenções de explicações, apesar de a investigação científica seguir procedimentos lógicos e ter base empírica. Em 1996, o "National Science Education Standards" (Padrões para a Educação Científica Nacional) enfatizou a natureza histórica, experimental, empírica, lógica e bem fundamentada das afirmações científicas. Esse documento destacou também os valores do ceticismo e da comunicação 
aberta, bem como a interação entre as crenças pessoais, sociais e culturais na geração de conhecimento científico (Adb-El-Khalick e Lederman, 2000, p. 668).

Essas discussões sobre o que foi tomado, historicamente, como núcleo central das discussões da NdC no ensino foram acompanhadas de uma problematização mais específica sobre quais aspectos da ciência são acessíveis aos estudantes e relevantes à sua formação científica. Algumas iniciativas ocorreram no sentido de identificar quais aspectos da ciência eram mais consensualmente aceitos como importantes. McComas, Almazroa e Clough relacionaram alguns desses aspectos, tais como: o conhecimento científico tem um caráter provisório; o conhecimento científico se baseia fortemente, mas não totalmente, na observação, em evidências experimentais, em argumentos racionais e no ceticismo; cientistas precisam manter seus registros, para revisão e replicabilidade; observações são guiadas por teorias; cientistas são criativos; leis e teorias possuem diferentes papéis na ciência; não existe um método único de se fazer ciência; a ciência é uma dentre outras formas de explicação do mundo; a ciência é parte de tradições culturais e sociais e pessoas provenientes de diferentes culturas contribuem para a ciência; ideias científicas são afetadas pelo contexto histórico e social; novos conhecimentos devem ser comunicados clara e abertamente; a história da ciência revela o caráter provisório do conhecimento científico; a ciência impacta a tecnologia e vice-versa (McComas, Almazroa e Clough, 1998, p. 513).

Outro estudo, realizado por Sue Collins e colaboradores (2001), buscou quais "ideias-sobre-ciências" (do inglês, ideas-about-science) devem ser ensinadas nos currículos de ciência. A pesquisa foi realizada a partir de opiniões de um grupo de especialistas em educação em ciências, cientistas, filósofos, historiadores e sociólogos da ciência. A partir da análise das respostas emergiram nove temas que poderiam ser incluidos no currículo de ciências, tais como: métodos científicos e testes (os experimentos servem para testar ideias); criatividade (a ciência, assim como outras atividades humanas, envolve imaginação e criatividade); desenvolvimento histórico do conhecimento científico (os alunos devem compreender a história da ciência para desenvolver uma compreensão adequada do conhecimento científico); ciência e questionamento (a ciência como um processo contínuo de procurar respostas que, então, geram novas questões); diversidade do pensamento científico (não 
há um método científico); análise e interpretação dos dados; ciência e certeza (o conhecimento científico atual está sujeito a alterações frente a novas evidências ou novas interpretações); hipótese e previsão (os cientistas desenvolvem hipóteses e previsões sobre fenômenos naturais); cooperação e colaboração no desenvolvimento do conhecimento científico (a ciência como uma atividade coletiva) (Collins e col., 2001).

Norman Lederman, autor de um dos instrumentos de coleta de dados desta pesquisa, o VNOS-C, também buscou identificar e definir os aspectos da $\mathrm{NdC}$ interessantes a serem trabalhados no ensino $(2002,2007)$. O seu trabalho estabeleceu um programa de pesquisa sobre $\mathrm{NdC}$ que foi muito influente nas pesquisas realizadas sobre o tema nos últimos anos. O programa de Lederman baseou-se em sete elementos que transcrevemos abaixo, conforme a formulação mais recente do autor (2007), aos quais acrescentamos títulos que julgamos indicarem sinteticamente cada aspecto. Assim, segundo Lederman, são os seguintes sete aspectos da $\mathrm{NdC}$ a serem trabalhados no ensino de ciências:

\section{- Observação e inferência ou a natureza empírica da ciência-}

Observações são afirmações descritivas sobre um fenômeno natural que são "diretamente" acessíveis aos sentidos (ou extensões dos sentidos) [...]. Inferências, por outro lado, vão além dos sentidos. [...] Um cientista pode inferir modelos ou mecanismos que explicam observações de fenômenos complexos (por exemplo, teoria evolutiva (Lederman, 2007, p. 833).

- Leis e teorias científicas - Leis e teorias são tipos diferentes de conhecimento, e um não se transforma em outro. Leis são afirmações ou descrições das relações entre fenômenos observados. [...] Teorias são explicações inferidas para fenômenos observáveis (Lederman, 2007, p. 833).

\section{- Criatividade e imaginação na construção do conhecimento} científico - Embora o conhecimento científico seja, ao menos parcialmente, baseado em ou derivado de observações do mundo natural (isto é, empírico), ele envolve, contudo, imaginação e criatividade humana. A ciência, ao contrário da crença comum, não é uma atividade totalmente sem vida, racional e ordenada. A ciência 
envolve a invenção de explicações, e isso requer grande dose de criatividade dos cientistas. Este aspecto da ciência, juntamente com sua natureza inferencial, implica que os conceitos científicos, tais como átomos, buracos negros e espécie, são modelos teóricos funcionais em vez de cópias confiáveis da realidade (Lederman, 2007, p. 834).

- O conhecimento científico é determinado por teoria - Os compromissos, crenças, conhecimentos prévios, treinamento, experiências e expectativas dos cientistas influenciam o seu trabalho. Todos esses fatores formam um estado mental que afeta o modo pelo qual conduzem suas investigações, o que eles observam (e o que não observam) e como eles dão sentido ou interpretam suas observações. É este estado mental ou esta individualidade (às vezes coletiva) que diz respeito ao papel da subjetividade na produção do conhecimento científico [...] (Lederman, 2007, p. 834).

- O conhecimento científico está inserido na cultura Compreensão de que a ciência é um empreendimento humano praticado no contexto mais amplo da cultura e seus praticantes (cientistas) são produto dessa cultura. Segue-se que a ciência afeta e é afetada pelos vários elementos e esferas intelectuais da cultura em que está inserida. Esses elementos incluem, mas não se limitam a, estrutura social, estruturas de poder, política, fatores socioeconômicos, filosofia e religião [...] (Lederman, 2007, p. 834).

- O conhecimento científico é provisório - Como consequência dos itens anteriores, a compreensão de que a ciência nunca é absoluta ou certa. Esse conhecimento, incluindo "fatos", teorias e leis, é sujeito a mudança. As afirmações científicas mudam na medida em que novas evidências, obtidas por meio de avanços na teoria e tecnologia, são confrontadas com as teorias e leis existentes, ou na medida em que antigas evidências são reinterpretadas à luz de novos avanços teóricos ou mudanças de direção de programas de pesquisa estabelecidos (Lederman, 2007, p. 834).

- Distinção entre NdC e investigação científica - É importante notar que as pessoas muitas vezes confundem a $\mathrm{NdC}$ com os processos ou 
investigação científica. Investigações científicas são atividades relacionadas com a coleta, análise de dados e elaboração de conclusões. Por outro lado a NdC refere-se aos fundamentos epistemológicos das atividades da ciência e as características do conhecimento resultante (Lederman, 2007, p. 835).

Como visto nesta seção, diversos pesquisadores buscam definir aspectos da ciência que seriam interessantes para o ensino. Porém também há críticas com relação à esse tipo de iniciativa. Gürol Irzik e Robert Nola (2011) argumentam que definições como essas levam muitos educadores a adotarem uma visão consensual sobre a $\mathrm{NdC}$ que não corresponde à realidade e que isso levaria ao ensino apenas as características da ciência que fizessem parte desse falso consenso. Alguns pesquisadores, como Douglas Allchin, 2010, questionam a validade desses testes por acreditar que eles não são capazes de revelar habilidades do pensamento crítico e analítico dos alunos, fundamental para a alfabetização científica (Allchin, 2010, p. 22). Outra crítica ainda é a da adoção desses elementos como "um mantra, um catecismo, como uma nova coisa a ser aprendida" (Matthews, 2012, p. 11).

Ora, quanto a esta última crítica, é importante considerar que esses aspectos não foram propostos como pontos de chegada, mas de início da busca por uma leitura e análise crítica da ciência. Além disso, ponderamos, em acordo com Matthews, que as listas de características da ciência, ainda que nunca definitivas ou completas, mostram-se úteis ao professor de ciências e efetivamente contribuíram por colocar NdC na sala de aula (Matthews, 2012, p. 11). Não sendo epistemólogo, o professor pode servir-se das discussões anunciadas por esses itens para refletir sobre a ciência que leciona e incorporar tais reflexões na sua prática docente. Na medida em que compreenda que nenhuma lista se pretende exaustiva ou completa, pode acessar diferentes itens de uma ou de outra lista conforme atenda melhor aos objetivos metacientíficos que estabelece em cada uma de suas ações pedagógicas ${ }^{1}$.

\footnotetext{
${ }^{1}$ Michael Matthews propõe o que prefere chamar de Aspectos da Ciência (AdC), (Features of Science, FOS), e relaciona nada menos que 18 itens que poderiam ser trabalhados no ensino. Além dos 7 indicados por Lederman, acrescenta 8) experimentação, 9) idealização, 10) modelos, 11) valores e temas sócio-econômicos, 12) matematização, 13) tecnologia, 14)
} 
No caso de Norman Lederman e seus colaboradores, os sete elementos balizaram a criação de diferentes instrumentos de pesquisa para avaliar as percepções de alunos e professores sobre NdC (os questionários VNOS que detalharemos na seção final deste capítulo). A rápida difusão alcançada por esses questionários na pesquisa em ensino também ilustra 0 anseio da comunidade por meios de avaliação de aprendizagem de NdC.

Antes de seguirmos à apresentação dos instrumentos de pesquisa que foram utilizados nesta pesquisa para investigar a concepção dos estudantes sobre a NdC, vamos vistoriar rapidamente as concepções filosóficas que serviram de substrato ao construto NdC discutido nesta seção. Quais discussões definiram o que compreendemos atualmente sobre o conhecimento científico e sua construção?

O próximo tópico apresenta algumas das posições da filosofia da ciência que auxiliaram na compreensão atual que temos sobre o que envolve a construção do conhecimento científico. Queremos destacar que somos conscientes de que as vertentes epistemológicas que serão apresentadas não fazem parte de um estudo detalhado, mas de um esboço que ao mesmo tempo que procura indicar origens filosóficas do construto $\mathrm{NdC}$ no ensino, será de auxílio para a análise dos resultados obtidos nesta dissertação, conforme apresentação retomada e sumarizada na seção 2.3.3.

\subsection{Concepções de ciência da filosofia da ciência do século XX}

Nas origens das ciências modernas, no século XVII, desenvolveram-se posições filosóficas que tentavam caracterizar a "estrutura do conhecimento" e as vias de acesso a ele, se por meio da razão ou da experiência. Embora o tema tenha origem na Antiguidade grega, o "problema do conhecimento" tornou-se um dos temas centrais do empreendimento filosófico dos modernos, originando a consolidação de uma disciplina específica, a Teoria do Conhecimento ou Epistemologia. 
Desenvolveram-se duas grandes correntes de pensamento que explicavam a via de acesso ao conhecimento. Uma delas foi a empirista, baseada no raciocínio indutivo. De acordo com a concepção empirista, o conhecimento científico sobre o mundo deriva de maneira rigorosa de dados de experiência obtidos por observação e experimentos (Chalmers, 2009, p. 23). Nessa perspectiva, as observações e experimentos permitem estabelecer induções que oferecem a definição do objeto, suas propriedades e suas leis de funcionamento. São, portanto, procedimentos que não apenas verificam e confirmam conceitos, mas os produzem. Daí a necessidade de estabelecer métodos experimentais rigorosos, pois deles dependia a formulação da teoria (Zaterka, 2004).

Assim, Francis Bacon (1561-1626), Galileu Galilei (1564-1642) e Isaac Newton (1642-1727) propunham que para compreender a natureza era necessário consultar a própria natureza. Note-se, contudo, que Galileu insistia no uso da experiência e da observação, mas concebidas não como meras compilações de dados sensíveis e, sim, como fornecedoras de dados que precisavam ser tratados teoricamente pela razão matemática (Zaterka, 2004). Em outras palavras, é preciso não confundir a posição empirista com um descaso à teoria ${ }^{2}$. Com Galileu, a base para a compreensão dos fenômenos é a quantidade e a geometrização do espaço, que passa a ser considerado como homogêneo e mensurável, isto é, objeto de tratamento matemático (Id.).

Esse mundo matemático e geométrico foi retomado por René Descartes (1596-1650). Contudo, para o filósofo francês, o mundo matemático é o mundo das ideias claras e distintas, únicas capazes de fornecer um conhecimento evidente e certo. Descartes pretendia que a matemática poderia ser aplicada não apenas à física, mas a todos os domínios do saber. Essa corrente, ainda que originária na Antiguidade grega, desenvolveu-se no século XVII e foi chamada racionalista, pois destacava a importância que a razão e os conceitos criados pela mente exercem no processo de formação e fundamentação do

\footnotetext{
${ }^{2}$ Luciana Zaterka chama a atenção para a simplificação excessiva que os manuais de história de filosofia da ciência produzem ao realçar a dicotomia entre racionalistas e empiristas. Essa simplificação deixa de lado o fato de que os pensadores do século XVII são todos, em certo sentido, racionalistas e que diferem quanto ao lugar que atribuem à experiência e à razão (a concepção racionalista é hipotético-dedutiva e a concepção empirista é hipotético-indutiva). De qualquer modo, racionalismo e empirismo possuem o mesmo pressuposto de que 0 conhecimento científico é uma explicação e uma representação verdadeira da própria realidade, tal como ela é em si mesma. (Zaterka, 2004).
} 
conhecimento científico. Para Descartes, a filosofia e a ciência são conhecimentos racionais dedutivos e demonstrativos, tais como a matemática. Por essas características, são conhecimentos que "provam" a verdade necessária e universal de seus enunciados. Nessa concepção, o conhecimento científico é uma representação intelectual universal, necessária e verdadeira das coisas representadas, e corresponde à própria realidade. As experiências científicas, na sua maioria, são realizadas apenas para verificar e confirmar as demonstrações teóricas e não para produzir o conhecimento do objeto, pois este é conhecido exclusivamente pelo pensamento (Zaterka, 2004).

De forma geral, foi o empirismo e sua base indutivista que prevaleceram nas ciências modernas desde o final do século XVII. O modo indutivista de conceber a ciência acabou por ressaltar ou criar uma equivalência entre "ciência" e "método científico". Contudo, o que ocorreu foi uma redução do que seriam os métodos das ciências a uma mera sequência de etapas do processo investigativo, iniciado pela observação e seguido por elaboração de hipótese, verificação da hipótese por meio de experimentos, comprovação ou não da hipótese e generalização indutiva para elaboração do conhecimento objetivo (Harres, 2000, p. 39-40).

Essa atitude foi designada "verificacionista", isto é, aquela que considera a verificação, por meio de experiências, o critério que valida as hipóteses científicas. Dessa forma, a tarefa do cientista seria a de verificar as teorias científicas. O mecanismo de como proceder uma tal verificação seria por indução, no qual a repetição sistemática e rigorosamente controlada dos experimentos, levaria a uma generalização, o que é chamado de empirismoindutivista (Medeiros e Bezerra, 2000, p. 110).

A conjunção destas duas posturas, empirismo-indutivista e verificacionista, caracterizam aquilo que diversos autores chamam hoje de indutivismo ingênuo (Medeiros e Bezerra, 2000, p. 110). Alan Chalmers (2009) acredita que esse indutivismo ingênuo está impregnado também na crença popular atual sobre o que é a ciência. Chalmers resume a forma como esse tipo de indutivismo concebe a formação do conhecimento científico com as seguintes palavras: 
De acordo com o indutivista ingênuo, a ciência começa com a observação. O observador científico deve ter órgãos sensitivos normais e inalterados e deve registrar fielmente o que puder ver, ouvir, etc. em relação ao que está observando, e deve fazê-lo sem preconceitos. Afirmações a respeito do estado do mundo, ou de alguma parte dele, podem ser justificadas ou estabelecidas como verdadeiras de maneira direta pelo uso dos sentidos do observador não preconceituoso. As afirmações a que se chega (vou chamálas de proposições de observação) foram então a base a partir da qual as leis e teorias que constituem o conhecimento científico devem ser derivadas. (Chalmers, 2009, p. 23)

No século $X X$, essas concepções passaram por diversas transformações. Uma delas deu origem ao denominada positivismo lógico, que surgiu no período entre guerras, quando a filosofia da ciência emergia como uma disciplina própria. Essa profissionalização da filosofia da ciência é atribuída a movimento de 1929 que se denominou Círculo de Viena (Lorenzano, 2004, p. 19). O Círculo de Viena foi formado por um grupo de estudiosos, organizados informalmente, que se reuniam para discutir os fundamentos da ciência. O grupo concebia o positivismo lógico como uma combinação entre os métodos da lógica e da matemática (componente do racionalismo), as ideias empiristas (o conhecimento se funda na evidência fornecida pela observação) e um ideal positivista (enfatizando a demarcação entre ciência e metafísica). Duas características marcantes do positivismo lógico são: hipóteses científicas em geral não podem ser completamente verificadas, mas somente confirmadas até um certo grau; e a concepção de unidade da ciência, no sentido de que todos os ramos da ciência devem compartilhar do mesmo método, o método científico (Pessoa Jr., 1993, p. 2).

A partir de ideias geradas a partir do positivismo lógico, Karl Popper (1902-1994) enfatizou que a ciência não procura verificar sentenças básicas, mas procura falseá-las. A concepção de Popper, chamada de falseacionismo foi apresentada no livro $A$ Lógica da Pesquisa Científica, de 1935, no qual pretendeu fundar uma epistemologia não-indutivista da ciência. Essa epistemologia baseia-se em três ideias: a rejeição à indução, o falseacionismo e a concepção da teoria cientifica como aproximação da verdade. Para Popper, 
toda tentativa de conferir feição lógica à indução está fadada ao fracasso (Costa, 2012, p. 21).

Dessa forma, as teorias científicas seriam hipóteses a partir das quais é possível deduzir enunciados comprováveis mediante a observação, e, se observações experimentais adequadas para esses enunciados revelarem-se falsas, a hipótese é refutada. Se uma hipótese superar o esforço de ser refutada, poderia ser aceita, ao menos em caráter provisório e assim nenhuma teoria poderia ser estabelecida de forma definitiva. Para Popper, tentar refutar uma hipótese, ou verificar sua falsificabilidade, apresenta-se como um critério de demarcação para as teorias científicas (e não a verificabilidade, como propõem os indutivistas) (Andrade, 2008, p. 25).

Uma crítica à forma de Popper compreender a construção do conhecimento científico é com relação à refutação das teorias, alegando que a falsificabilidade é falível, portanto inconclusiva, já que seus testes envolvem experimentos e observações que são impregnados por teorias. Da mesma forma que a base empírica não fornece total segurança para "comprovar" uma teoria, ela também não será segura o suficiente para falseá-la (Andrade, 2008, p.26).

A partir dos anos sessenta, do século $X X$, e que foi dominante nos anos setenta e início dos anos oitenta, do mesmo século, houve um direcionamento para uma perspectiva histórica na filosofia da ciência, que marcou o desenvolvimento posterior da reflexão metacientífica no ensino. Aumentou a importância dos estudos históricos e sociais, o problema da carga teórica que as observações continham, e o problema das noções de progresso. Nessa nova fase da filosofia da ciência se destacaram filósofos como Paul Feyerabend (1924-1994), Thomas S. Kuhn (1922-1996) e Imre Lakatos (19221974) (Lorenzano, 2004, p. 21).

Talvez um dos maiores marcos da Filosofia da Ciência do século XX foi a abordagem histórica que Thomas Kuhn deu à ciência, apresentada em seu livro A estrutura das Revoluções Científicas, de 1962. Para Kuhn, a ciência é entendida como uma atividade que se dá ao longo do tempo e que em cada época histórica apresenta peculiaridades e características próprias. Assim, deveriam ser considerados os aspectos históricos que rodeiam a atividade científica, e não só os empíricos. Para Kuhn, a ciência evolui de modo a 
aproximar-se da verdade, e essa aproximação é feita pela substituição de teorias, ou como denomina Kuhn, por meio de revoluções científicas, nas quais um paradigma é substituído por outro (Kuhn [1962], 2009). Para Kuhn, os paradigmas são "realizações científicas universalmente reconhecidas que, durante algum tempo, fornecem problemas e soluções modelares para uma comunidade de praticantes de uma ciência" (Kuhn [1962], 2009, p. 13).

Por sua vez, o húngaro Imre Lakatos apresentou uma "metateoria" (teoria sobre a teoria) que embora incorpore algumas ideias de Kuhn, difere dele em diversos pontos e assimila uma versão do falseacionismo de Popper (Pessoa Jr., 1993, p. 5). Imre Lakatos em seu livro A Metodologia dos Programas de Investigação Científica, de 1977, descreveu a ciência como um "programa de pesquisa". Para Lakatos um programa de pesquisa é uma estrutura que fornece orientação para a pesquisa futura. Para ser considerado um programa científico deve possuir um grau de coerência que envolva o mapeamento de um programa definido para a pesquisa futura e deve levar à descoberta de fenômenos novos (Chalmers, 2009, p.112-116). Para ele, todos os programas possuem um núcleo que lhes confere unidade. Este núcleo é associado a uma heurística que determina dois tipos de regras metodológicas: uma que diz os caminhos de pesquisa que devemos evitar, a heurística negativa, e outra que diz a forma como prosseguir, a heurística positiva. 0 heurística negativa proíbe refutar o núcleo, para o qual deve haver um cinturão protetor de hipóteses auxiliares ou complementares que podem ser modificadas. A heurística positiva sugere como modificar e desenvolver esta parte modificável, refutável, do programa de pesquisa (Díez e Moulines, 1999, p. 318-319). Assim, o desenvolvimento da ciência para Lakatos não ocorre pelas revoluções ou mudanças de paradigma descritos por Kuhn, mas pela superação de um programa de pesquisa por outro que explica tudo que o outro programa esclarece e ainda mais.

Merece destaque a preocupação de Lakatos, assim como de Kuhn, em incorporar a história para fundamentar sua filosofia e explicar como a historiografia da ciência deve aprender com a filosofia da ciência e vice-versa. Lakatos dizia que: "A filosofia da ciência sem história da ciência é vazia; a história da ciência sem a filosofia da ciência é cega" (Lakatos, 1970, p. 91). 
Paul Karl Feyerabend sustentou que a ciência normal, na qual há a predominância de um único paradigma, é um mito que não tem respaldo metodológico nem histórico. Assim, a ciência progrediria a partir da interação de teorias que tentam se desenvolver e simultaneamente se confrontam com outras teorias e dessa forma tudo o que possa facilitar o desenvolvimento de novas teorias seria recomendável (Villani, 2001, p. 171). Em síntese, Feyerabend defende um pluralismo metodológico, onde o critério é o tudo vale.

Após um período marcado pela preocupação histórica houve um crescimento de abordagens sociológicas, afirmando que a sociologia seria capaz de explicar que o conhecimento científico é produto de influências essencialmente sociais e que fatores de ordem cultural e que interesses sociais possuiriam papel proeminente na aceitação ou rejeição dos resultados da ciência (Shinn e Ragouet, 2008, p. 59-60). O ponto de partida da sociologia da ciência foi a retomada da discussão sobre a sociologia do conhecimento, baseada nos resultados da história da ciência e da filosofia da ciência (Pessoa Jr., 1993, p. 7-8) ${ }^{3}$.

Para finalizar, é importante fazer um paralelo dessas concepções com o que aparece nos manuais de ensino de ciências e biologia da educação básica. Em geral, eles expressam somente a correspondência direta entre método científico e as etapas empregadas na investigação científica, afirmando que existe um único método na ciência caracterizado pela observação, hipótese, experiência, resultados, interpretação e conclusão (Dourado e Sequeira, 2002). Vimos na breve discussão acima que essas etapas traduzem uma concepção indutivista da ciência que ignora que há métodos diversos nas ciências (o experimental, o comparativo, o descritivo), e que hoje se considera que a atividade de investigação é composta por uma multiplicidade de sequências possíveis. A sequência padrão indutivista não passa de uma reconstrução linear do processo de investigação científica que é realizada à posteriori, depois de o investigador já ter encontrado resposta para suas interrogações (Giordan, 1999).

\footnotetext{
${ }^{3}$ Temos ciência de que outras epistemologias foram desenvolvidas nas últimas décadas, causando impactos importantes, tais como as de Larry Laudan, Stephen Toulmin, Humberto Maturana, Mario Bunge e lan Hacking. No entanto, consideramos que, para os propósitos desta dissertação, as ideias mencionadas acima são suficientes para balizar a análise dos dados obtidos em nossa pesquisa. Em outras palavras, consideramos que são aquelas as principais concepções ilustradas nos instrumentos de pesquisa aqui utilizados.
} 
Apesar das grandes alterações ocorridas nas concepções epistemológicas de ciência ao longo do século XX, os projetos curriculares mais marcantes para o ensino de ciências mantiveram a perspectiva indutivista. Isso ocorreu, para citar um exemplo da área da biologia, no Biological Science Curriculum Studies (BSCS), que foi traduzido e adaptado como material instrucional para os estudantes brasileiros nos anos 1970. Essas ideias estão tão presentes nos livros didáticos até hoje, que não apenas foram interiorizadas pelos professores de ciências como estão expressas em muitos currículos de ciências (Hodson, 1988) e em algumas práticas educacionais (Praia, 1999).

Tendo essas concepções como pano de fundo das discussões sobre a Natureza da Ciência, podemos seguir, agora, à apresentação e discussão dos diferentes instrumentos planejados nos últimos anos para coletar dados sobre tais concepções entre estudantes e professores.

\subsection{Instrumentos de coleta de dados para investigação de noções sobre NdC}

Frente a importância de se preocupar com o ensino da NdC precisamos também nos atermos à métodos que permitam investigar o conhecimento dos alunos sobre esses conteúdos epistemológicos. Esse é o objetivo de diversas pesquisas nas últimas décadas e, por isso, diversas ferramentas têm sido desenvolvidas e utilizadas na condução de pesquisas relacionadas ao levantamento das noções acerca de NdC para diferentes públicos.

O principal propósito da avaliação educacional é o de diagnosticar. Uma das inquietações dos educadores consiste em se inteirarem do alcance da aprendizagem atingida por cada estudante que está sob sua responsabilidade. Para investigar se o educando está alcançando as metas traçadas para seu ensino é necessário que façamos diagnósticos do processo educativo (Goring, 1981, p.12). Uma das formas de realizar esse diagnostico é por meio da utilização de questionários.

Diversos questionários têm sido desenvolvidos nas últimas décadas e utilizados na condução de pesquisas relacionadas ao levantamento das noções 
acerca de NdC para diferentes públicos. Inicialmente, a maioria das pesquisas adotavam metodologias quantitativas. Um dos primeiros trabalhos com 0 objetivo de, elaborar um instrumento para identificar concepções de estudantes acerca da NdC foi o de Leland Wilson, em 1954. A partir desse trabalho, diferentes instrumentos de coleta de dados se seguiram, como o Science Process Inventory, desenvolvido por Wayne Welch, em 1967; o Test on Understanding Science, por William Cooley e Leopold Klopfer, em 1961; o Nature of Science Scale, de Mekritt Kimball, em 1967-68; e o Nature of Scientific Knowledge Scale, desenvolvido por Peter Rubba, em 1977.

Após o final dos anos 1980, os estudos sobre a NdC deixaram de ser exclusivamente quantitativos e passaram a focalizar aspectos qualitativos, que é o que prevalece atualmente (Harres, 1999, p. 197-198). Por isso, os questionários passaram a ser compostos por questões abertas, como é o caso do que foi desenvolvido por Norman Lederman e Molly O’Malley, em 1990, e foi intitulado questionário VNOS, sigla em inglês de Views on Nature of Science (Visões da Natureza da Ciência). Posteriormente, foram desenvolvidos vários tipos de VNOS, conforme o público a que se destina, oferecendo variações e melhorias em relação ao original.

Um deles, o VNOS-A, também desenvolvido por Lederman e O'Malley em 1990, é composto de sete questões e voltado para alunos do ensino médio. Este questionário foi projetado para ser usado em conjunto com entrevistas, e cada uma das sete questões incide sobre cada um dos sete aspectos da NdC que Lederman considera relevantes no ensino, conforme expostos na seção 1 deste capítulo.

Os outros questionários são VNOS-B, VNOS-C, VNOS-D e VNOS-E. O VNOS-B foi desenvolvido para avaliar o conhecimento de professores de ciências do ensino médio. É um questionário longo, que exige mais tempo para ser respondido. Os VNOS-D e VNOS-E são facilmente administrados em menos de uma hora, sendo o primeiro criado para ser administrado a professores do ensino fundamental e o segundo para alunos muito novos, podendo inclusive ser utilizado com alunos que não sabem ler ou escrever; representa, portanto, a primeira proposta de avaliação de NdC para um público do ensino fundamental e da pré-escola (Lederman, 2007). 
O VNOS-C destina-se a avaliar uma série de aspectos relacionados às concepções dos professores do ensino fundamental e médio, sobre a $\mathrm{NdC}$ de uma forma relativamente simples e, por ser um dos questionários adotados nesta pesquisa será apresentado com mais detalhes no capítulo 2 .

Como exemplo de questionário que leva a análise quantitativa, composto de questões com respostas de múltipla escolha, podemos citar o VOST (sigla do inglês Views on Science-Technology-Society; em português: Visões de Ciência-Tecnologia-Sociedade), elaborado por Aikenhead e Ryan (1992). Esse questionário constitui-se de 114 itens e busca investigar concepções de alunos sobre tópicos da ciência, tecnologia e sociedade.

O questionário COCTS (sigla a partir do espanhol Cuestionario de Opiniones sobre Ciencia, Tecnología y Sociedad) é outro que utiliza questões de múltipla escolha para investigar crenças sobre ciência, tecnologia e sociedade. Ele é composto de cem questões, desenvolvidas a partir de respostas anteriores, coletadas a partir de questões abertas e entrevistas. Segundo os autores, o questionário produzido dessa forma tem o objetivo de evitar que as concepções de ciência dos autores estejam implícitas no questionário (Manassero, Vázquez, Acevedo, 2003). Outro exemplo de questionário que utiliza itens de múltipla escolha, seguindo escala de Likert, é o VOSE (sigla do inglês Views on Science and Education Questionnaire) que por ser uma das ferramentas, junto com o VNOS-C, adotadas nesta pesquisa será abordado com mais detalhes no capítulo 2 .

O questionário UNOS (Understanding of the Nature of Science Scale) também é baseado na escala de Likert, só que utiliza uma escala de 4 pontos de concordância. Esse questionário contém 27 itens e busca investigar três aspectos da $\mathrm{NdC}$, que são: se o conhecimento científico atual é provisório e sujeito a mudanças; se cientistas que investigam um mesmo fenômeno natural, terão as mesmas conclusões; e se as atitudes e interesses do público em geral influencia os cientistas (Lin, 1996).

Um exemplo de questionário que é composto por questões fechadas, mas que os alunos devem responder seguindo um escore de 0 a $10 \mathrm{em}$ grau de concordância é o questionário CESC (Concepções de Estudantes Sobre a Natureza das Ciências). O CESC, desenvolvido por Eraldo J. M. Tavares, Charbel Niño El-Hani e Pedro Rocha, em 2006, busca obter informações a 
respeito de nove temas epistemológicos. O questionário foi planejado para ser aplicado junto a estudantes de graduação em Ciências Biológicas e contêm questões com conteúdos de ciências afins, como a Química e a Geologia, além das Ciências Biológicas.

Há também instrumentos quali-quantitativos, isto é, que possuem questões abertas e fechadas, como o questionário SUSSI, (sigla em inglês de Student Understanding of Science and Scientific Inquiry; em português: Compreensão dos Estudantes sobre Ciência e Investigação Científica), desenvolvido por Ling L. Liang e colaboradores em 2006. Esse questionário foi aplicado junto a alunos do ensino básico e superior, por professores de disciplinas científicas nos Estados Unidos, China e Turquia. A combinação de análise quantitativa e qualitativa permitiu, segundo os autores, aumentar a sensibilidade do instrumento a fim de detectar influências culturais (Liang e col, 2006, p. 22).

Em um de seus artigos, Lederman (1992) revisa mais de vinte trabalhos relacionados apenas com investigações acerca das concepções de $\mathrm{NdC}$ de estudantes. Identifica, junto aos questionários já validados pela literatura, outras ferramentas para obtenção de dados qualitativos, tais como debates em pequenos grupos, entrevistas, revisões de planos de aula, observações de salas de aula e de professores e mapas conceituais.

Ferramentas como as apresentadas nunca estarão prontas e, como a própria ciência, estão sujeitas a melhorias e alterações. Mesmo sabendo das críticas que já foram mencionadas na seção 1.1, insistimos em que elas não deixam de ser úteis por ser um meio de garantir a introdução da discussão sobre NdC no ensino.

A respeito da validade de medições educativas, Paul Goring defende que "não se deve dizer simplesmente que uma medição é ou não válida, porque a validade das medições educativas nunca é absoluta, mas relativa, e nenhuma das medições que o educador aplica aos seus alunos é completamente válida" (Goring, 1981, p. 19). Assim, cabe descobrirmos se os resultados da investigação por meio destes questionários são úteis para melhorarmos o ensino de $\mathrm{NdC}$. Acreditamos que devemos continuar a desenvolver métodos que permitam investigar o desenvolvimento estudantil para melhorar o ensino: 
O diagnóstico do desenvolvimento ou modificações dos comportamentos estudantis deve ter como fim indicar o valor das experiências de aprendizagem, com vista a efetuar as devidas modificações no futuro programa de ensino (Goring, 1981, p. 13).

Em que pesem as dificuldades da utilização dos questionários, e as limitações de cada um, nesta pesquisa partiu-se do pressuposto de que eles fornecem pistas para o professor e pesquisador sobre o modo pelo qual os estudantes concebem a ciência. Utilizados para a realização de sondagens de concepções prévias, possibilitam o desenvolvimento de estratégias de ensino mais efetivas e contextualizadas para o ensino de NdC concomitantemente ao ensino do conteúdo científico. Aplicados ao final de uma intervenção didática, podem fornecer dados para uma avaliação de modo a balizar o trabalho futuro, e orientar o desenvolvimento de concepções mais complexas da $\mathrm{NdC}$ entre os alunos, como é almejado pela educação em ciências na atualidade.

O breve levantamento acima indica que há várias formas de se pesquisar as visões dos estudantes acerca da Natureza da Ciência. O que deve ser feito é avaliar qual ferramenta é mais adequada para cada público: alunos de diferentes níveis de ensino, professores em exercício, professores em formação, pesquisadores de Ensino de Ciências, pesquisadores de áreas científicas. Uma ferramenta que levante concepções de NdC deve também ser adequada a objetivos e delimitação própria de cada pesquisa, como, por exemplo, quais os aspectos da NdC se pretende estudar. Para isso devem ser realizados testes e, por vezes, modificações nos instrumentos a fim de adequálos à objetivos de pesquisa e/ou de ensino específicos.

Pesquisas, como esta, que se preocupam em coletar dados para uma avaliação do ensino sobre a NdC podem trazer dados significativos para a utilização desses instrumentos por professores de ciências; para o aperfeiçoamento desses instrumentos; e para o desenvolvimento de outros instrumentos. Também poderemos realizar comparações com outras pesquisas realizadas sobre concepções da NdC. Assim será possível detectarmos as carências e potencialidades do ensino de NdC, não só no curso de Ciências Biológicas da USP mas também de outros cursos de ciências. 
Pesquisas empíricas sobre as concepções dos estudantes nos fornecem subsídios para detectarmos as carências e potencialidades no ensino de ciências para que possamos repensar a forma como está sendo ensinada a ciência atualmente. As pesquisas sobre o entendimento da $\mathrm{NdC}$, tornam-se elementos vitais no desenvolvimento de um conhecimento mais completo do conteúdo pedagógico para o ensino da ciência. Se o objetivo da formação de professores de ciências é preparar os professores para ensinar para a alfabetização científica, a instrução sobre a NdC deve ser uma parte integrante da formação de professores (Eick, 2000).

Nesse contexto este trabalho realiza uma análise do desenvolvimento da concepção dos alunos que cursaram o primeiro semestre letivo do Curso de Ciências Biológicas do Instituto de Biociências da Universidade de São Paulo, sobre a Natureza da Ciência ( $\mathrm{NdC}$ ), a partir da utilização de dois questionários disponíveis na literatura, VNOS-C e VOSE, que serão detalhados a seguir. 


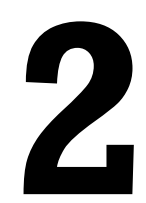

PLANEJAMENTO DA PESQUISA 
O objetivo deste capítulo é apresentar o percurso metodológico seguido na investigação.

A presente pesquisa pode ser definida como um estudo de caso focado nos alunos que ingressaram no curso de Ciências Biológicas do Instituto de Biociências da Universidade de São Paulo, no ano de 2010. Sobre estudos de caso Sturman diz:

Estudo de caso é um termo genérico para a pesquisa de um indivíduo, um grupo ou um fenômeno. Enquanto que as técnicas usadas nessa pesquisa podem variar e incluir tanto enfoques qualitativos como quantitativos, a característica que mais distingue o estudo de caso é a crença de que os sistemas humanos desenvolvem uma completude e integração, isto é, não são simplesmente um conjunto de partes ou de traços. Por conseguinte, o estudo de caso encaixa em uma tradição holística de pesquisa segundo a qual as características de uma parte são determinadas grandemente pelo todo ao qual pertence (Sturman, 1988, p. 61).

Por se tratar de uma pesquisa que envolve seres humanos, devemos nos manter preocupados com relação aos possíveis efeitos desta intervenção sobre o(s) sujeito(s), preservando-os fisicamente, subjetivamente $\mathrm{e}$ socialmente. Pensando nisso e para estarmos de acordo com a Resolução 196/96 do Ministério da Saúde em relação às pesquisas com seres humanos (BRASIL, 1996), foi desenvolvido e aplicado um Termo de Consentimento Livre e Esclarecido junto às pessoas pesquisadas (Anexo 1).

A fim de não influenciar as atitudes de professores e alunos, não houve participação deste pesquisador em nenhuma das disciplinas oferecidas aos alunos, durante o período que esta pesquisa buscou investigar. Um dos motivos que motivaram a escolha deste distanciamento foi para evitar que os professores trabalhassem os temas pesquisados devido ao fato de 0 pesquisador estar em sala de aula. Assim como Bogdan e Biklen (2006), acreditamos que o envolvimento no ambiente da pesquisa também dificultaria o distanciamento necessário para a realização de uma análise imparcial dos dados. Pessoas intimamente envolvidas possuem dificuldade em distanciar-se, quer de preocupações pessoais, quer do conhecimento prévio que possuem das situações. 


\subsection{O contexto da pesquisa: o curso de Ciências Biológicas do IB-USP}

A pesquisa foi desenvolvida no contexto do Curso de Graduação em Ciências Biológicas do Instituto de Biociências da Universidade de São Paulo (IB-USP). Esse contexto foi escolhido devido ao curso possuir um Projeto Pedagógico que nos parece em sintonia com a tendência de um ensino contextual de ciência, conforme mencionado na Introdução desta dissertação. Um dos fatores necessários para essa formação nas Ciências Biológicas envolve, portanto, conhecimentos sobre a $\mathrm{NdC}$.

\subsubsection{Amostra}

A amostra foi composta por alunos ingressantes, matriculados no primeiro semestre letivo do Curso de Graduação em Ciências Biológicas do IBUSP no ano de 2010 e professores das disciplinas desse primeiro semestre letivo.

A amostra foi escolhida devido a particularidades encontradas na grade curricular do primeiro semestre do curso e nas características das disciplinas oferecidas aos alunos ingressantes, disponíveis no Manual da graduação 2010 do Curso de Ciências Biológicas.

O total de disciplinas sugeridas para o primeiro semestre do curso são: Genética, Filosofia das Ciências Biológicas, Princípios de Sistemática e Biogeografia; Fauna, Flora e Ambiente; Diversidade Biológica e Filogenia; Antropologia: Biologia e Cultura; e Noções de Estatística. Dentre essas disciplinas, nós consideramos que algumas são mais particularmente relevantes para a construção de percepções aprofundadas acerca da Natureza da Ciência entre os alunos. Trata-se de Genética; Filosofia das Ciências Biológicas; Antropologia: Biologia e Cultura; Fauna, Flora e Ambiente; e Diversidade Biológica e Filogenia (as ementas dessas disciplinas estão no Anexo 2).

Essas cinco disciplinas nos aparecem como mais diretamente relacionadas a discussões sobre a $\mathrm{NdC}$ porque suas ementas indicam 
abordagens mais ou menos explícitas sobre a construção do conhecimento científico.

A disciplina de Genética aborda todo o seu conteúdo científico segundo uma perspectiva histórica. Essa opção configura o que Matthews denominou abordagem integrada (integrated approach) do uso da História da Ciência no ensino, em contraposição à abordagem inclusiva (add-on approach) (Matthews, 1994, p. 70). Segundo Matthews, a abordagem inclusiva caracteriza-se pela utilização de episódios históricos específicos dentro de um curso de ciência padrão, não histórico. Por sua vez, a abordagem integrada caracteriza-se por situar a perspectiva histórica como linha condutora de todo o conteúdo científico a ser trabalhado em um determinado curso com os estudantes (Prestes e Caldeira, 2009, p. 7).

De fato, o programa da disciplina Genética está baseado em um texto que traz uma abordagem integrada da História da Biologia no ensino, escrito por John A. Moore em 1986, intitulado "Science as a way of knowing" (Ciência como uma forma de conhecimento). Esse texto foi traduzido e adaptado por professores do Departamento de Genética e Biologia Evolutiva da USP ${ }^{4}$ e vem sendo utilizado como material didático nas aulas da Genética desde 1995.

A disciplina Filosofia das Ciências Biológicas aborda questões intrínsecas da $\mathrm{NdC}$, por exemplo: como se alcança, como se estabelece e como muda o conhecimento científico; características que distinguem a investigação científica de outros tipos de investigação e conhecimento; que condições devem ser satisfeitas para uma explicação científica ser aceitável; predisposições dos cientistas e avaliação das teorias científicas; a ciência como uma forma de conhecimento; teorias, indução e dedução, entre outros.

A disciplina Fauna, Flora e Ambiente enfatiza uma abordagem que supera as delimitações das subáreas da Biologia e promove diversas oportunidades de discussões metacientíficas, tais como a da articulação entre Ciência, Tecnologia e Sociedade.

Podemos observar na ementa da disciplina Antropologia da Ciência que ela também traz diversos aspectos epistemológicos como, por exemplo, uma discussão sobre o pensamento positivista.

\footnotetext{
${ }^{4}$ IB-USP, 2009, tradução feita por Almeida, E.J.C.; Amabis, J.M.; Benozzati, M.L.; BitnerMathé, B.C.; Dessen, E.M.; Menck, C.F.M.; Mori, L.; Vilela, C.R. e Yassuda, Y.Y.
} 
A disciplina Diversidade Biológica e Filogenia aborda questões sobre a história das classificações dos seres vivos.

Além dos indicativos das ementas das disciplinas do primeiro semestre, outro fator importante na escolha da aplicação da pesquisa junto a esses alunos foi o interesse em conhecer as noções sobre ciência que trazem do Ensino Médio e começam a transformar no início da formação superior numa das diversas áreas da ciência, no caso, as Ciências Biológicas.

\subsection{Triangulação}

A triangulação tem sido compreendida como a adoção de múltiplas percepções, a fim de clarear o significado de determinada observação ou interpretação alcançada por uma ou mais fontes de dados e para ampliar a compreensão das diferentes formas pelas quais o fenômeno é percebido (Mafezzolli e Boehs, 2008, p. 104), configurando-se como uma estratégia importante para alcançar a credibilidade (Sturman, 1988, p.65). Yin (2005, p.126) considera que a questão da validade e da confiabilidade de um estudo de caso se resolve, em parte, pela triangulação efetuada através da utilização de múltiplas fontes de evidência que convergem para o mesmo conjunto de fatos, fenômenos ou estudos de realidade.

De acordo com a classificação de Denzin (1988, p. 319), utilizamos nessa pesquisa duas formas de triangulação:

- triangulação de dados que envolve tempo, espaço e pessoas diferentes;

- triangulação metodológica, que se caracteriza por envolver o uso de mais de um método e poder consistir em estratégias intra métodos ou entre métodos.

Nesta pesquisa a triangulação de dados envolveu dois grupos de pessoas: alunos e professores. Já a triangulação metodológica envolveu a utilização de diferentes estratégias metodológicas, expressas em quatro instrumentos diferentes: um Questionário Sociocultural e de Opinião Sobre a Importância da NdC, o questionário VNOS-C e o questionário VOSE, ambos 
para coleta de dados sobre a concepção de $\mathrm{NdC}$, e entrevistas semiestruturadas.

\subsubsection{Triangulação de dados}

\subsubsection{Alunos}

Nossa intenção foi a de realizar uma pesquisa com todos os alunos matriculados no primeiro semestre de 2010 do curso de Ciências Biológicas da USP, porém, para estudo comparativo entre as duas fases de aplicação do questionário, foram analisados apenas os alunos que realizaram as duas etapas de aplicação dos questionários. As duas etapas de aplicação dos questionários (início e fim do semestre) geraram:

- Dezessete (17) alunos responderam o questionário VNOS-C, totalizando trinta e quatro (34) questionários nas duas etapas;

- Vinte e oito (28) alunos responderam o questionário VOSE, totalizando cinquenta e seis (56) questionários respondidos nas duas etapas.

\subsubsection{Professores}

Foram entrevistados cinco professores de disciplinas disponíveis no primeiro semestre do curso de Ciências Biológicas do IB-USP. Para seleção dos professores foram enviados emails para dois professores, definidos aleatoriamente, de cada uma das disciplinas do primeiro semestre letivo do curso de Ciências Biológicas disponibilizadas pelo IB-USP.

Os professores entrevistados foram aqueles que responderam o email, mostrando a intenção de participar da pesquisa. Apenas um dos professores que respondeu o email não foi entrevistado, isso ocorreu devido a incompatibilidade de datas para a entrevista entre 0 pesquisador e entrevistado. 


\subsubsection{Triangulação metodológica}

\subsubsection{Questionário sociocultural e de opinião}

Foi elaborado e aplicado o Questionário Sociocultural e de Opinião Sobre a Importância da NdC (Anexo 3) com os alunos. Esse questionário foi aplicado apenas na segunda etapa de aplicação dos questionários, no final do primeiro semestre letivo. A partir dele tivemos o objetivo de caracterizar o perfil dos alunos investigados e também buscarmos a opinião dos alunos a respeito dos aspectos investigados.

O perfil dos alunos investigados foi traçado a partir da investigação do sexo, idade, algumas características da formação escolar e participação na renda familiar.

Com relação à opinião dos alunos com relação à importância da $\mathrm{NdC}$ o objetivo foi 0 de saber se os alunos pensaram nas perguntas durante 0 semestre e se os conteúdos abordados nos questionários VNOS-C e VOSE seriam ou não relevantes para o ensino deles. Com essa investigação buscamos saber se há interesse dos alunos com relação às questões investigadas ou mesmo se eles perceberam, durante as disciplinas, alguma menção dos professores com relação às questões investigadas. Isso foi investigado pelas questões sete e oito do Questionário Sociocultural e de Opinião Sobre a Importância da NdC.

\subsubsection{Entrevistas}

As entrevistas semiestruturadas com os professores foram direcionadas de forma a investigar:

- se o professor concordava que a abordagem de questões sobre a NdC é importante durante a formação dos biólogos e em que estágio da formação do aluno seria mais interessante que fosse trabalhada. Para saber a opinião dos professores sobre essa questão foi apresentado e discutido, de forma breve, quais os aspectos da $\mathrm{NdC}$ relacionados pelo Norman Lederman; 
- se algum dos aspectos da NdC foram trabalhados ao longo da disciplina por ele ministrada e se foram trabalhados de forma implícita ou explícita;

- se o professor lembrava de algum momento da disciplina no qual aspectos da NdC foram trabalhados;

- se houve, na disciplina, alguma avaliação que buscasse saber se aspectos da NdC foram apreendidos pelos alunos ou mesmo se o professor conseguiu perceber algum aprendizado sobre conteúdos metacientíficos.

Todas as entrevistas foram integralmente transcritas e estão apresentadas no Anexo 4.

Com o objetivo de facilitar a apresentação dos dados obtidos nas entrevistas, as transcrições das entrevistas receberam códigos de referência. Os códigos de referência são compostos por letras e números, respectivamente para o nome do professor e para o trecho da entrevista. Dessa forma, os professores entrevistados e as referentes letras que serviram de código foram: Dra. Mariana Cabral de Oliveira - $\underline{A}$; Dr. Luis Eduardo Soares Netto - B]; Dr. Paulo Takeo Sano - $\underline{\text {; }}$; Dr. Carlos Ribeiro Vilela - ㅁ; Dr. Rui Sergio Sereni Murrieta - E.

As transcrições das entrevistas foram organizadas em tabelas, conforme a Tabela 1: 


\begin{tabular}{|l|l|l|}
\hline \multicolumn{1}{|c|}{ Turno } & \multicolumn{1}{|c|}{ Tempo } & \multicolumn{1}{c|}{ Fala } \\
\hline Para melhor localização dos & Tempo decorrido & Buscamos \\
trechos analisados, as falas & desde o início do & transcrever as \\
dos professores foram & arquivo transcrito. & falas fielmente. \\
divididas em turnos. Cada & Possibilita termos & As ocorrências \\
turno possui um código de & ideia do tempo & não verbais \\
referência, que é composto & despendido nos & estão entre \\
da letra que representa o & diálogos. Os & parênteses. \\
professor e um número que & tempos estão & \\
indica o trecho da entrevista. & marcados em: & \\
& minutos e & \\
& segundos & \\
\hline
\end{tabular}

Tabela 1 - Quadro representativo da organização das transcrições.

2.2.2.3 Questionários para coleta de dados acerca da NdC: VNOS-C e VOSE

Os questionários VNOS-C e VOSE foram aplicados nos períodos noturno e integral e em duas etapas, no início e no final do semestre letivo. Cerca de metade da turma, selecionada aleatoriamente, respondeu ao VNOSC e a outra metade ao VOSE, repetindo-se o mesmo questionário para os mesmos alunos no final do semestre (primeira e segunda etapas).

O questionário VNOS-C (do inglês, Views of the Nature of Science, Form C; Visões da Natureza da Ciência - Modelo C), elaborado e validado por Norman Lederman e colaboradores (2002), foi utilizado nesta pesquisa a partir da tradução e adaptação realizada por Charbel Niño El-Hani, 2004 (Anexo 5). Esse questionário contém 11 questões dissertativas (questões abertas). Foi desenvolvido para professores do ensino fundamental e médio, o que consideramos constituir-se uma ferramenta adequada para ser utilizada junto à formação de futuros professores da área científica. Além disso, é um questionário elaborado e validado por pesquisadores com ampla experiência em investigações sobre o tema. Por já ter sido aplicado em pesquisa realizada no Brasil, seriam permitidas correlações com os resultados encontrados no 
presente estudo, dentro de um contexto de diversas similaridades (estudantes brasileiros, de ensino superior, de cursos de Ciências Biológicas, de Universidades públicas).

O questionário VOSE (do inglês, Views on Science and Education Questionnaire; Questionário de Noções sobre Ciência e Educação) foi desenvolvido por Sufen Chen, em 2006, traduzido do inglês para o português pelo autor desta pesquisa (Anexo 6). É constituído de 15 questões fechadas, divididas em 85 itens, elaboradas segundo escala de Likert. A escolha da ferramenta VOSE se deu justamente pelo fato de utilizar a escala Likert que pode ser facilmente administrada e compreendida pelos alunos (Malhotra, 2006, p. 265). Também escolhemos esse questionário por ser um instrumento de coleta de dados quantitativos, que serviriam de comparação aos dados qualitativos obtidos a partir do VNOS-C.

Para facilitar a identificação das respostas, nas duas etapas, e manter 0 sigilo da identidade dos alunos, foram atribuídos números de identificação para cada aluno. Os alunos que responderam o VNOS-C receberam números de identificação de 1 a 17. Já os alunos que responderam o VOSE, receberam números de identificação de 18 a 45 . Todas as respostas investigadas dos alunos, tanto do questionário VNOS-C quando do VOSE, estão nos Anexos 7 e 8 , respectivamente.

Estamos cientes das potencialidades e limitações que cada um dos métodos utilizados pelos questionários para coletar os dados. Randy Bell (2003, p. 355), por exemplo, afirma que questões abertas dão mais liberdade para os respondentes expressarem suas próprias visões do empreendimento científico e também ajudam a evitar a imposição da visão dos pesquisadores. Contudo, questionários com questões fechadas permitem que um maior número de questões seja aplicado em um só questionário, já que, geralmente, exigem menos esforço para serem respondidos e o processo de tabulação ser mais simples (Gil, 1999, p. 131). Devido a essas diferenças de características é que escolhemos os dois métodos como ferramentas para realizar a coleta de dados.

Também nos preocupamos em coletar dados sobre os tempos de resposta de cada questionário por acreditarmos ser necessário o conhecimento 
aproximado dessa variável na hora de os professores planejarem a sua aplicação.

\subsection{Análise}

\subsubsection{Análise do Questionário Sociocultural e de Opinião Sobre a Importância da NdC}

Foi realizada a análise quantitativa das questões que buscaram caracterizar o perfil dos alunos investigados, a partir do cálculo da média e desvio-padrão das idades e cálculo das porcentagens dos alunos com relação à formação escolar e participação da renda familiar.

Com relação à opinião dos alunos sobre os aspectos investigados foi realizada tanto uma análise quantitativa quanto uma análise qualitativa. A análise quantitativa pretendeu saber quantos alunos lembraram das questões pesquisadas ao longo do semestre, quais questões envolvidas na pesquisa foram lembradas e quantificar o percentual de alunos que declarou considerar importante o conhecimento das questões investigadas nessa pesquisa para um biólogo.

A análise qualitativa foi realizada a partir das respostas dadas à questão 8 do Questionário Sociocultural e de Opinião Sobre a Importância da NdC na qual buscamos criar categorias de análise que buscassem apresentar os argumentos dos alunos utilizados para justificar a importância de se conhecer as questões investigadas nos questionários VNOS-C e VOSE.

\subsubsection{Análise das entrevistas com os professores}

As entrevistas semiestruturadas, por serem desprovidas de roteiros estritos de investigação, foram úteis para fornecer informações das possíveis influências que os alunos tiveram, ao longo do semestre, em sala de aula, a respeito de aspectos da $\mathrm{NdC}$. Para que a investigação com os professores auxiliasse na elucidação do foco da pesquisa, buscamos identificar trechos das 
entrevistas que apresentassem as preocupações, intenções e possíveis abordagens dos professores com o ensino de questões metacientíficas e relacioná-las com a análise das respostas fornecidas pelos alunos.

\subsubsection{Análise dos questionários para coleta de dados acerca da} NdC: VNOS-C e VOSE

As diferenças de opinião sobre quais aspectos da $\mathrm{NdC}$ devem ser abordados no ensino de ciências, conforme apareceram neste trabalho, devem-se, a nosso ver, aos diferentes interesses de pesquisa e/ou prática de ensino. Com esse pressuposto, esta pesquisa não pretendeu valorar os dois questionários analisados quanto aos aspectos de $\mathrm{NdC}$ que contemplam, mas utilizar os questionários para investigar as respostas dos alunos referentes aos seguintes aspectos da NdC: leis e teorias cientificas, criatividade e imaginação na construção do conhecimento científico, o conhecimento científico é determinado por teorias, a ciência está inserida na cultura, e o conhecimento científico é provisório. Dessa forma, fizemos uma seleção das questões apresentadas pelos dois questionários, com o objetivo de centralizar a investigação das respostas sobre os aspectos da $\mathrm{NdC}$ relacionados acima. Os aspectos da $\mathrm{NdC}$ e as respectivas questões investigadas foram as da Tabela 2:

\begin{tabular}{|c|c|c|}
\hline $\begin{array}{l}\text { Aspectos da Natureza da Ciência } \\
\text { investigados }\end{array}$ & $\begin{array}{l}\text { Questões } \\
\text { - VNOS-C }\end{array}$ & $\begin{array}{c}\text { Questões e Itens - } \\
\text { VOSE }\end{array}$ \\
\hline Leis e teorias cientificas & 6 & 7A, 7B, 7C, 7D \\
\hline $\begin{array}{l}\text { A criatividade e imaginação na } \\
\text { construção do conhecimento } \\
\text { científico }\end{array}$ & 10 & $3 \mathrm{~A}, 3 \mathrm{~B}, 3 \mathrm{C}, 3 \mathrm{D}, 3 \mathrm{E}$ \\
\hline $\begin{array}{l}\text { O conhecimento científico é } \\
\text { determinado por teorias }\end{array}$ & 9 & $\begin{array}{c}8 \mathrm{~A}, 8 \mathrm{C}, 15 \mathrm{D}, 15 \mathrm{E} \\
15 \mathrm{H} \mathrm{E} \mathrm{15I}\end{array}$ \\
\hline $\begin{array}{l}\text { O conhecimento científico está } \\
\text { inserido na cultura }\end{array}$ & 11 & $2 \mathrm{~A}, 2 \mathrm{~B}, 2 \mathrm{C}, 2 \mathrm{D}$ \\
\hline $\begin{array}{l}\text { O conhecimento científico é } \\
\text { provisório }\end{array}$ & 7 & $4 \mathrm{~A}, 4 \mathrm{~B}, 4 \mathrm{C}$ \\
\hline
\end{tabular}

Tabela 2 - Aspectos da NdC investigados e as questões dos questionários VNOS-C e VOSE utilizadas. 
A análise das respostas fornecidas ao questionário VNOS-C foi realizada a partir da categorização das respostas. O critério de categorização escolhido para a investigação das respostas dos alunos foi o semântico, conforme descrito por Bardin. No critério de categorização semântico são criadas categorias temáticas, isto significa que, todas as respostas que estiverem relacionadas a um determinado tema serão agrupadas em uma determinada categoria (Bardin, 2011, p. 147).

Para realizar essa investigação semântica selecionamos a unidade de registro, que é o segmento do conteúdo considerado a unidade base, de acordo com o tema. Segundo Bardin o tema é:

A unidade de significação que se liberta naturalmente de um texto analisado segundo certos critérios relativos à teoria que serve de guia à leitura. $\mathrm{O}$ texto pode ser recortado em ideias constituintes, em enunciados e em proposições portadores de significações isoláveis. (Bardin, 2011, p. 135)

A definição das unidades de registro ocorreu a partir de uma ou mais dimensões ${ }^{5}$, o que permitiu ampliar a análise.

Após a definição das unidades de registro foram elaboradas as categorias, que foram construídas a priori ou a posteriori. As categorias a priori foram obtidas diretamente da questão do VNOS-C e as categorias construídas a posteriori, foram obtidas a partir das próprias respostas dos alunos.

Com as respostas dos alunos analisadas separadamente para cada etapa de aplicação do questionário foi possível realizar a comparação entre as duas etapas.

Para investigar a opinião dos alunos, obtidas a partir da ferramenta VOSE, foi estabelecido o Ranking Médio (RM) das respostas, para cada uns dos itens do questionário (Malhotra, 2006, p. 265-267; Oliveira, 2005). Como o questionário utilizou uma escala Likert de 5 pontos para mensurar o grau de concordância dos alunos, para cada um dos itens do questionário, o RM pode variar entre 1, menor grau de concordância e 5, maior grau de concordância. Quando um determinado item recebeu um valor do RM menor que 3 quer dizer

\footnotetext{
${ }^{5}$ Como exemplo, as respostas de uma determinada questão puderam ser investigadas sob a dimensão "quando" - quando queremos investigar o momento de determinado fenômeno, ou pela dimensão "para que" - quando queremos investigar a finalidade de determinado fenômeno ocorrer.
} 
que os alunos não concordaram com o enunciado do item e, para valores maiores que 3 , foi considerado que os alunos concordaram com o enunciado. O valor exatamente 3 foi considerado como indiferente. Assim observamos a mudança do RM entre as duas etapas de aplicação do questionário para analisar o grau de concordância dos alunos.

\subsubsection{Parâmetros teóricos para análise das respostas}

Com o objetivo de servir de base teórica para a investigação realizada por nós, não utilizamos apenas as definições utilizadas por Lederman para os aspectos investigados nessa pesquisa. A partir de posições de alguns filósofos, como os discutidos na seção 1.2 do capítulo 1, bem como de alguns educadores buscamos identificar quais são concepções dos alunos. Para isso, elaboramos a síntese que se segue.

Com relação às leis e teorias científicas - elas são produtos da ciência, igualmente maduros e formas únicas de conhecimento científico. Compreender as distinções e relações entre leis e teorias é essencial para boa compreensão e avaliação do trabalho do cientista (McComas, 2003, p.2).

No que diz respeito às teorias científicas Cibelle Silva e Roberto Martins (2003) dizem que não são induções, mas sim hipóteses que vão necessariamente além das observações e elas não podem ser provadas. Em outras palavras, teorias seriam explicações inferidas para fenômenos observáveis (Lederman, 2007, p. 833). Feyerabend (1977) ainda completa que a proliferação de teorias é benéfica para a ciência, ao passo que a uniformidade Ihe debilita o poder crítico.

Com relação às leis cientificas, elas são afirmações ou descrições das relações entre fenômenos observados (Lederman, 2007, p. 833). A lei científica é uma generalização, uma regularidade que se aplica universalmente e são elaboradas (alguns diriam "descobertas") a partir de fatos e explicam e prevêem ocorrências individuais (Carey, 1994; Carnap, 1966; Mayr apud McComas, 2003, p. 4).

São diversas as discussões filosóficas a respeito de leis e teorias científicas e, por isso, para os nossos objetivos, não esperávamos um conhecimento aprofundado dos alunos sobre leis e teorias. Consideramos em 
nossa análise avaliar se os alunos possuem alguma compreensão de que leis e teorias cientificas: não são verdades absolutas; são formas diferentes de conhecimento; não há uma hierarquia entre elas; e que uma não se transforma na outra devido ao acúmulo de evidências (Horner e Rubba 1979).

Sobre o aspecto a criatividade e imaginação na construção do conhecimento científico - a ciência envolve a invenção de explicações, e isso requer grande dose de criatividade dos cientistas (Lederman, 2007, p. 834). Sobre esse aspecto da NdC, buscamos investigar principalmente se os alunos aceitavam ou não haver participação da criatividade e imaginação na construção do conhecimento científico.

Com relação ao conhecimento científico ser determinado por teorias - embora a ciência dependa da evidência, as atividades científicas são orientadas por teorias e os cientistas realizam as suas investigações a partir de referenciais teóricos determinados. Entre outras coisas, esse referencial é formado pelos conhecimentos prévios estabelecidos pela comunidade científica, treinamento, experiências e pela própria escolha entre as teorias que orientam o trabalho do cientista (Adb-El-Khalick e Lederman, 2000, p. 668). É essa influência, a de que os cientistas realizam pesquisas orientados pelos conhecimentos prévios e a partir de um referencial que procuramos investigar se os alunos apresentam.

Para o conhecimento científico estar inserido na cultura observamos que os conceitos são construções que foram inventadas e impostas sobre os fenômenos para interpretá-los e explicá-los e, muitas vezes são resultado de grandes esforços intelectuais. Dessa forma o conhecimento científico é construído e comunicado através da cultura e das instituições sociais da ciência (Driver e col., 1999, p. 32). Por se tratar de uma construção humana a ciência resulta de uma prática cujo desenvolvimento se faz por meio de processos sociais e racionais, tratando-se claramente de um fato cultural (Canavarro, 1999). É essa compreensão, a de que a ciência é uma construção humana e que se desenvolve dentro de uma cultura que esperamos dos alunos.

Sobre o aspecto o conhecimento científico é provisório - Popper diz:

A ciência não é um sistema de declarações certas e bem estabelecidas; nem é ela um sistema que avança para um estado final. Nossa ciência não 
é conhecimento (episteme) ela nunca pode pretender haver atingido a verdade, nem mesmo um substituto para ela, como a probabilidade" (Popper, 2005, p. 278).

Apesar das críticas existentes com relação à compreensão que Popper apresentou de ciência, esperamos que os alunos estejam de acordo quando ele, e outros pensadores, afirmam que a ciência é um sistema que avança e que ela nunca pode pretender atingir a verdade.

Com a utilização das ferramentas e procedimentos de análise adotados para cada questionário não tivemos a intenção de classificar os alunos (Goring, 1981, p.14) como tendo um maior ou menor conhecimento sobre a NdC, mas de realizar um diagnóstico desse conhecimento.

A seguir apresentaremos a análise das respostas dos alunos referentes aos aspectos da $\mathrm{NdC}$ abordados no dois questionários e as relações com as respostas fornecidas no Questionário Sociocultural e de Opinião Sobre a Importância da NdC e nas entrevistas com os professores.

Para cada um dos aspectos da NdC serão apresentadas duas tabelas, referentes a cada uma das etapas de aplicação do questionário, obtidas a partir das respostas do questionário VNOS-C seguida de discussão sobre os resultados. Posteriormente apresentaremos uma tabela contendo o RM obtido a partir dos resultados das respostas dadas ao questionário VOSE, nas duas etapas, e posterior discussão dos resultados. Ao final de cada tópico finalizamos com uma síntese que irá comparar as respostas obtidas nos dois questionários e demais considerações. 


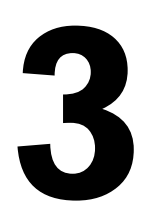

RESULTADOS E DISCUSSÃO 


\subsection{Aplicação dos questionários: perfil dos participantes e tempos de resposta}

A idade média dos alunos foi de 19,6 anos. Na Tabela 3 abaixo, apresentamos as idades médias e desvios-padrão obtidos entre homens e mulheres.

\begin{tabular}{|cccc|}
\hline & Homens & Mulheres & Geral \\
\hline Idade média & 19,95 & 19,3 & 19,6 \\
\hline Desvio-padrão & 4 & 1,99 & 3,01 \\
\hline
\end{tabular}

Tabela 3 - Idade média e desvio-padrão das idades dos alunos.

A partir da investigação que fizemos, quanto à formação e participação na renda familiar, obtivemos os seguintes dados da Tabela 4:

\begin{tabular}{|c|c|c|c|c|}
\hline & HOMENS & MULHERES & TOTAL & $\%$ \\
\hline \multicolumn{5}{|l|}{ Formação } \\
\hline Fez ou faz outro curso superior & 1 & 2 & 3 & $(7 \%)^{*}$ \\
\hline Não fez outro curso superior & 19 & 23 & 42 & $(93 \%)$ \\
\hline E. Fundamental - Escola Pública & 3 & 4 & 7 & $(15 \%)$ \\
\hline E. Fundamental - Escola Particular & 17 & 21 & 38 & (84\%) \\
\hline E. Médio - Escola Pública & 1 & 8 & 9 & $(20 \%)$ \\
\hline E. Médio - Escola Particular & 19 & 17 & 36 & $(80 \%)$ \\
\hline \multicolumn{5}{|l|}{ Participação na renda familiar } \\
\hline $\begin{array}{l}\text { Não trabalha e recebe ajuda } \\
\text { financeira da família. }\end{array}$ & 18 & 23 & 41 & (91\%) \\
\hline $\begin{array}{l}\text { Trabalha e recebe ajuda financeira } \\
\text { da família. }\end{array}$ & 1 & 1 & 2 & $(4,5 \%)$ \\
\hline $\begin{array}{l}\text { Trabalha e contribui parcialmente } \\
\text { para o sustento da família. }\end{array}$ & 0 & 1 & 1 & $(2,25 \%)$ \\
\hline $\begin{array}{l}\text { Trabalha e é responsável pelo } \\
\text { sustento da família. }\end{array}$ & 1 & 0 & 1 & $(2,25 \%)$ \\
\hline
\end{tabular}

* - Porcentagem aproximada

Tabela 4 - Nível de formação e participação na renda familiar dos alunos investigados. 
Observamos que a maioria dos alunos investigados (93\%) não cursavam ou cursaram, até o momento da pesquisa, outro curso superior. O interesse em investigar isso era saber se as concepções dos alunos poderiam conter influências de outros cursos de graduação. Ainda com relação à formação, observamos que a grande maioria dos alunos teve sua formação no Ensino Fundamental e Médio em escolas particulares, o que já indica uma seleção, realizada pelo vestibular, no perfil dos alunos que investigamos.

Com relação à participação na renda familiar também observamos a seleção de alunos, com $91 \%$ dos alunos sem trabalhar e recebendo auxilio financeiro da família. Observando o perfil dos alunos, percebemos que o grupo investigado é um grupo formado por alunos que tiveram acesso a condições de ensino privilegiadas, quando comparadas ao padrão de ensino brasileiro e que, provavelmente, podem se dedicar, de forma exclusiva, ao curso de Ciências Biológicas.

Quanto ao tempo de duração do primeiro e do último aluno a devolver o questionário respondido, em cada uma das etapas, construímos a Tabela 5:

\begin{tabular}{|c|c|c|}
\hline \multicolumn{3}{|c|}{ VOSE } \\
\hline & $\begin{array}{c}\text { PRIMEIRA } \\
\text { ETAPA }\end{array}$ & $\begin{array}{c}\text { SEGUNDA } \\
\text { ETAPA }\end{array}$ \\
\hline Primeiro a entregar & $18 \mathrm{~min}$ & $9 \mathrm{~min}$ \\
\hline Último a entregar & $43 \mathrm{~min}$ & $49 \mathrm{~min}$ \\
\hline & VNOS-C \\
\hline Primeiro a entregar & $\begin{array}{c}\text { PRIMEIRA } \\
\text { ETAPA }\end{array}$ & $\begin{array}{c}\text { SEGUNDA } \\
\text { ETAPA }\end{array}$ \\
\hline Último a entregar & 20 min & 19 min \\
\hline
\end{tabular}

Tabela 5 - Tempos de resposta.

Observamos, nas duas etapas de aplicação do questionário, que o VOSE foi entregue com um menor tempo de resposta do que o VNOS-C, havendo uma diferença mais acentuada na segunda etapa. Com exceção desse menor tempo do VOSE na segunda etapa, não foram observadas diferenças significativas entre o menor e maior tempo de duração de resposta dos dois questionários. 
Os tempos de resposta registrados nesta pesquisa para o VOSE, diferiram do que obteve Sufen Chen (2006). A pesquisadora registrou que os participantes demoraram aproximadamente 15 minutos para responder 0 questionário, contrastando com os nossos tempos de $18 \min$ a $43 \min \left(1^{a}\right.$ etapa) e $9 \min$ a $49 \min$ (2 $2^{a}$ etapa). Quanto ao tempo máximo, é preciso salientar que o questionário VOSE foi respondido de forma mais rápida que o VNOS-C, considerando-se a totalidade dos respondentes, pois a maior parte dos questionários foi entregue antes da metade do tempo proposto (aproximadamente 25 minutos).

Nas duas etapas o tempo mínimo registrado nesta pesquisa para aplicação do VNOS-C também contrastou com o registrado por Norman Lederman para o mesmo questionário. Na pesquisa de Lederman, foram gastos entre 45-60 minutos para que os alunos respondessem ao questionário (Lederman, 2002, p. 511), em contraste aos nossos 19 min e 50 min. Contudo, considerando a totalidade dos respondentes, o VNOS-C demandou mais tempo para sua aplicação com relação ao VOSE, pois grande parte dos alunos entregou seus questionários faltando poucos minutos para o final da atividade (prevista para 50 minutos, como mencionado anteriormente).

\subsection{Opinião dos alunos sobre as questões da pesquisa}

A partir da análise quantitativa da opinião dos alunos a respeito de terem lembrado das questões envolvidas na pesquisa, questão 7 do Questionário Sociocultural e de Opinião Sobre a Importância da NdC, foi obtida a Tabela 6, abaixo:

\begin{tabular}{|lcccccc|}
\hline & & & Homens & Mulheres & Total & $\%$ \\
\hline \multirow{2}{*}{$\begin{array}{l}\text { Lembrou das questões } \\
\text { ao longo do semestre }\end{array}$} & SIM & 6 & 6 & 12 & $27 \%$ \\
\cline { 2 - 7 } & NÃO & 10 & 15 & 25 & $55 \%$ \\
\cline { 2 - 7 } & NÃO RESP. & 4 & 4 & 8 & $18 \%$ \\
\hline
\end{tabular}

Tabela 6 - Quantidade de alunos que lembraram das questões durante 0 semestre. 
Observamos que a maior parte dos alunos (55\%) declarou não ter lembrado das questões ao longo do semestre. De certa forma, esse resultado era esperado já que as questões dos questionários VNOS-C e VOSE não são conteúdos explícitos das disciplinas. Acreditamos que a não participação deste pesquisador nas disciplinas do primeiro semestre auxiliou para a maioria dos alunos não pensarem nas questões durante o semestre. Essa decisão planejada permitiu que aplicássemos o questionário na segunda etapa sem que os alunos estivessem intencionalmente preparados para responder às questões, o que poderia interferir nos objetivos da investigação.

A partir dos doze alunos que responderam terem lembrado as questões ao longo do semestre e deram exemplos do que lembraram, realizamos também a análise qualitativa, o que gerou a Tabela 7 abaixo:

\begin{tabular}{|cc|}
\hline Tópicos da ciência lembrados & $\begin{array}{c}\text { Número } \\
\text { de alunos }\end{array}$ \\
\hline Definição de leis, teorias e hipóteses & 5 \\
\hline Ética nas ciências & 3 \\
\hline Influência sociocultural & 3 \\
\hline Conceito de ciência & 2 \\
\hline Método científico & 2 \\
\hline Influência dos paradigmas nas linhas & 1 \\
\hline de pesquisa & 1 \\
\hline Criatividade e imaginação na ciência & 1 \\
\hline Conceito de espécie & 1 \\
\hline Evolução de conceitos & 1 \\
\hline
\end{tabular}

Tabela 7 - Aspectos da NdC que foram lembrados pelos alunos.

Observamos que um grande número das questões relacionadas à ciência, e que foram investigadas nos questionários, foram lembradas por alguns alunos ao longo do semestre. 
Três alunos declararam ter se lembrado da questão sobre ética nas ciências. Um dos alunos disse: "Sim. Perguntas referentes a valores morais e éticos". Essa questão da ciência não foi abordada em nenhum dos questionários, mas foi trabalhada de forma explícita pelo professor Rui Murieta, na disciplina Filosofia das Ciências Biológicas. Sobre a abordagem do conteúdo ética em sala de aula o professor Rui disse (turno E8):

Uma novidade dos últimos dois anos, que é o foco, duas aulas que nós temos, sobre ética, que foi uma demanda dos alunos. Os alunos tinham esse problema na cabeça e achavam interessante ter, pelo menos uma aula sobre ética e... ética na biologia especificamente.

Mesmo muitos alunos afirmando não ter lembrado das questões ao longo do semestre, um aluno declarou que durante as aulas essas questões foram abordadas, dizendo: "No curso mesmo foram abordados vários desses temas como a construção do conhecimento, conceitos de teoria, lei,etc."

A Tabela 8 apresenta a análise quantitativa que fizemos à pergunta 8 do Questionário Sociocultural e de Opinião Sobre a Importância da NdC. Nela observamos que a maior parte dos alunos, $76 \%$, considerou importante que essas questões sejam conhecidas pelos biólogos.

\begin{tabular}{|c|c|c|c|c|c|}
\hline & & Homens & Mulheres & Total & $\%$ \\
\hline \multirow{3}{*}{$\begin{array}{l}\text { Considera importante o } \\
\text { conhecimento das } \\
\text { questões para um }\end{array}$} & SIM & 14 & 20 & 34 & $76 \%$ \\
\hline & NÃO & 1 & 0 & 1 & $2 \%$ \\
\hline & NÃO RESP. & 5 & 5 & 10 & $22 \%$ \\
\hline
\end{tabular}

Tabela 8 - Análise quantitativa das respostas à questão 8 do questionário sociocultural.

Também realizamos uma análise qualitativa das respostas dos alunos que declararam ser importante que um biólogo conheça as questões investigadas. A partir das respostas foram criadas categorias, o que gerou a Tabela 9, abaixo: 


\begin{tabular}{|lc||}
\hline \multicolumn{1}{|c|}{ Consideram importante } & $\begin{array}{c}\text { Número de } \\
\text { alunos }\end{array}$ \\
\hline Para estar atualizado e compreender melhor a ciência. & 7 \\
\hline Para a profissão do biólogo. & 6 \\
\hline Porque confere maior credibilidade às decisões do biólogo. & 5 \\
\hline Para esclarecer à população acontecimentos científicos. & 5 \\
\hline Para refletir sobre si e o que está fazendo. & 5 \\
\hline Para compreender como funciona e avança a ciência. & 4 \\
\hline Porque são essenciais para ética científica. & 3 \\
\hline Para o biólogo ter noção de seu papel na sociedade. & 1 \\
\hline
\end{tabular}

Tabela 9 - Análise qualitativa das respostas à questão 8 do questionário sociocultural.

Observamos que parte das categorias obtidas estão de acordo com os apontamentos levantados por Rosalind Driver e colaboradores (1996, p. 23) sobre a importância de se aprender sobre a NdC, apresentados no tópico 1.2 da dissertação.

\subsection{Entrevista semiestruturada com professores}

Juntamente com o Questionário Sociocultural e de Opinião Sobre a Importância da $\mathrm{NdC}$, as entrevistas semiestruturadas com os professores foram realizadas como parte da triangulação e a partir delas observamos que os professores entrevistados declararam que suas disciplinas se preocuparam em trabalhar questões sobre a ciência, seja de forma implícita ou explícita. Essa influência pode ter sido provocada por professores, envolvidos nas disciplinas, que são envolvidos ou tem contato com pesquisas em ensino de ciências ou com filosofia das ciências. Dentre os professores que não foram entrevistados, mas que foram lembrados nas entrevistas estão: a professora Dra. Sônia Godoy Bueno Carvalho Lopes, da disciplina Diversidade Biológica e Filogenia e o professor Dr. José Mariano Amabis, que participou do planejamento inicial da disciplina de Genética e ainda ministra a aula inicial da disciplina. A professora 
Mariana Oliveira ao falar sobre uma aula da professora Sônia Lopes, declarou a preocupação em apresentar a ciência de forma historicamente construída e a ciência como um conhecimento provisório e em constante desenvolvimento (Turno A6):

A Sônia dá uma aula que vai desde Aristóteles, passa por todo... como que o conhecimento da diversidade era organizado, passa por toda aquela história da criação dos reinos, todos os modelos que foram feitos e como eles evoluíram até os cinco reinos e depois a gente introduz o que a gente está usando como uma classificação atual. Que é baseada em árvore filogenética, então como eles veem, a grande maioria deles, ainda vem da escola... a gente dá esse assunto no início do primeiro semestre. Ainda vem da escola com esse negócio de reino muito arraigado, né, reino vegetal, reino animal. A gente, para não chocá-lo já fala: olha tudo isso aqui você quer, e nós vamos usar isso aqui, a gente põe todo um contexto histórico. Então tem uma aula que acho que é uma das primeiras aulas que a gente coloca esse contexto histórico.

Já o professor Luis Netto destacou a influência que teve o professor Mariano Amabis na elaboração da disciplina Genética em se preocupar em transmitir como o conhecimento científico foi gerado (Turno B24):

Acho que essa ideia de mostrar como o conceito é gerado, como aqueles conceitos, que hoje a gente assume, no momento atual é aceito, como é que eles foram gerados, num dado momento, num dado contexto. Eu acho isso importantíssimo. Que mostra de novo que não existe uma verdade absoluta, que isso pode ser mudado... Eu acho que a disciplina de genética... muito por influência do professor Mariano e essa preocupação de mostrar um pouco como que o conhecimento é gerado.

Ainda com relação à preocupação das disciplinas em trabalhar a construção de conhecimento científico de forma historicamente construída, o professor Luis Netto também destacou (Turno B10):

Se a gente pegar na biologia, na genética, a quantidade de informação que é gerada é monumental. Então é muito difícil você querer acompanhar, né. O mais importante é querer entender um pouco como o conhecimento é gerado, o contexto, o momento histórico que é gerado... Acho que tem toda 
uma ideia de estudar um pouco a genética num contexto histórico que é dado na disciplina... Todos os conceitos que a gente vai abordar: padrão de herança, dominância e recessividade... a gente está abordando de uma forma histórica que traz como o conhecimento é gerado.

O interesse da disciplina Genética em trabalhar o conhecimento historicamente construído já era conhecido por nós devido a utilização do livro do John Moore, Science as a Way of Knowing. O professor Carlos Vilela também relatou essa preocupação (Turno D4):

O principio norteador da nossa disciplina é a construção do conhecimento científico né, que é o projeto do Moore, Science as a Way of Knowing, agente analisa a parte de genética é literalmente aquele texto traduzido... Então a nossa ideia é essa, mostrar para os alunos a evolução do conhecimento científico.

A disciplina Diversidade Biológica e Filogenia também destacou a preocupação de apresentar que o conhecimento anterior não era errado, apenas que era o aceito na época e que se desenvolveu ao longo da história. Com relação aos aspectos da $\mathrm{NdC}$ relacionados por Lederman, diríamos que seria uma forma de apresentar aos alunos que o conhecimento científico é provisório e em constante desenvolvimento. Sobre isso a professora Mariana Oliveira diz (Turno A6 e Turno A10):

A gente sempre tenta colocar no contexto histórico de que a ferramenta que eles tinham naquela época permitiu eles chegarem até aquele ponto. Então isso é uma coisa que a gente sempre trabalhou muito no curso... Como todo esse processo de classificação mais atual ainda tá muito fluido, ainda tá mudando, a gente sempre coloca que ele deve avaliar tudo muito criticamente. $O$ fato de estar no livro não significa que daqui dois meses não vá estar tudo diferente. Então que eles têm que ter uma postura muito crítica em relação à bibliografia e poder ficar atentos a essa questão de mudança do conhecimento.

Sobre a definição de leis e teorias científicas o professor Rui Murieta relatou a dificuldade que os alunos apresentam, dizendo (Turno E20): 
A distinção de leis e teorias a... o conceito de teoria, principalmente é pensado e é utilizado de uma forma absolutamente vulgar né, que você utiliza no cotidiano. As pessoas confundem hipótese com teoria e especulação com teoria. Elas não entendem que a teoria já é um momento avançado do processo metodológico científico.

Também observamos uma preocupação em trabalhar questões sobre a ciência de forma explícita. Como exemplo, o professor Rui Murieta discute, em sala de aula questões sobre empirismo e racionalismo (Turno E6):

É uma discussão que é bem orientada para isso. Principalmente a primeira parte... a segunda parte também, mas a primeira parte onde você da um... faz uma tomada geral do... cenário, principalmente pré-moderno... e moderno, falando de empirismo e racionalismo.

Trabalhar o contexto científico de forma explícita, de forma a envolver o aluno em uma cultura científica e apresentar a influência social, cultural e histórica também é um dos objetivos da disciplina Fauna, Flora e Ambiente, e pôde ser observado na declaração do professor Paulo Sano (Turno C2):

A disciplina... tem essa intenção, é uma questão de intencionalidade mesmo, de prover essa introdução ao universo da cultura científica, vamos chamar assim... alguns elementos que agente procura trabalhar, primeiro, a ciência ela é produzida, uma produção humana. Como produção humana ela tá sujeita a um contexto social, cultural e histórico.

Como podemos observar, os professores declararam ter trabalhado, em sala de aula, alguns dos aspectos da NdC investigados. Dentre as questões sobre a ciência lembrados pelos professores destaco: a ciência como uma forma de conhecimento historicamente construído; a ciência como um conhecimento provisório e em constante desenvolvimento; a ciência imersa em um contexto sociocultural; e a definição de leis e teorias científicas.

A declaração dos professores está de acordo com o apresentado na seção anterior (3.2 Opinião dos alunos sobre as questões da pesquisa). Nessa seção, apresentamos que diversos alunos lembraram, ao longo do semestre, de questões como: distinção entre leis e teorias e a influência sociocultural na ciência. As questões que surgem são: Porque será que os alunos não 
percebam ou lembraram de outros aspectos da NdC que os professores disseram ter trabalhado em sala de aula? Será que os alunos incorporaram, de alguma forma, esses e outros aspectos da $\mathrm{NdC}$, mesmo sem perceberem isso? A segunda questão foi uma das preocupações levantas pelos próprios professores. A professora Mariana Oliveira mostrou se preocupar com a dificuldade em saber o quanto os alunos assimilaram os conteúdos trabalhados (Turno A48):

A gente sabe que a gente trabalha, mas a gente não sabe o quanto isso passa para os alunos, né? O que realmente eles percebem disso aqui! A gente fala muito! A gente fala claramente todas estas questões, uma coisa explícita mesmo, não é uma coisa que está implícita. A gente realmente fala estas questões e tudo. Questões da avaliação crítica do conhecimento... que tem interpretação... para a gente seria interessante saber se realmente está passando para eles, se eles tem esta percepção. Minha curiosidade maior seria essa.

Outra preocupação, desta vez levantada pelo professor Luis Netto foi a de trabalhar o ensino de forma intuitiva, sem uma base científica, e o interesse em trabalhar cientificamente o ensino. No turno B57 da entrevista ele diz:

A gente não tem certeza se está fazendo certo ou não tá, o que tem que melhorar. Acho importante esse tipo de... na área... a gente faz muitas coisas intuitivamente né, a verdade é essa... Trabalhar do modo científico também a parte de ensino. Não ficar tanto no eu acho. A gente faz muito isso.

Essas preocupações devem ser levadas em conta quando nos preocupamos em investir no Ensino de Ciências. As ferramentas de investigação sobre a NdC podem servir como recursos a serem utilizados para os professores elaborarem disciplinas que se preocupem com um ensino contextualizado, obtendo informações sobre os conhecimentos científicos prévios dos alunos e sobre os conhecimentos adquiridos pelos alunos após as disciplinas.

Com relação à preocupação de estar transmitindo o conhecimento de forma contextualizada e que traga aspectos da $\mathrm{NdC}$, acreditamos que a 
presença de professores envolvidos com pesquisas e metodologias de Ensino de Ciências,como nas diversas disciplinas investigadas, auxilie nessa questão.

Apresentamos, na seção seguinte, as respostas dos alunos aos questionários VNOS-C e VOSE, procurando estabelecer algumas relações entre as entrevistas com os professores e as mudanças das respostas dos alunos.

\subsection{Investigação das respostas dos alunos - questionários VNOS-C e VOSE}

\subsubsection{A criatividade e imaginação na construção do conhecimento científico}

Segundo o referencial do capítulo 1 e da seção 2.3.4, sobre este aspecto da NdC, buscamos investigar principalmente se os alunos aceitavam ou não haver participação da criatividade e imaginação na construção do conhecimento científico. O tema participação da imaginação e criatividade na ciência é abordado,de forma explícita, na questão 10 do VNOS-C e na questão 3 do VOSE.

A análise das respostas obtidas na questão 10 do VNOS-C gerou as Tabelas 10 e 11 referentes, respectivamente, à primeira e à segunda etapa da pesquisa. Apenas 16 alunos responderam a essa questão nas duas etapas, o aluno de número 17 não consta na tabela por ter respondido a apenas uma etapa. 


\begin{tabular}{|l|c|c|c|c|c|}
\hline \multicolumn{1}{|c|}{ Para que? } & $\begin{array}{c}\text { Interpretar } \\
\text { os dados }\end{array}$ & $\begin{array}{c}\text { Elaborar } \\
\text { teorias e } \\
\text { leis }\end{array}$ & $\begin{array}{c}\text { Explicar } \\
\text { quando não } \\
\text { acham } \\
\text { respostas }\end{array}$ & $\begin{array}{c}\text { Discutir a } \\
\text { realização } \\
\text { da coleta de } \\
\text { dados }\end{array}$ & $\begin{array}{c}\text { Nenhuma } \\
\text { referência } \\
\text { ao motivo } \\
\text { do uso }\end{array}$ \\
\hline $\begin{array}{l}\text { Projeto e } \\
\text { planejamento }\end{array}$ & $2^{*}, 13$ & $\begin{array}{c}6,10,14, \\
16\end{array}$ & & 1 & 15 \\
\hline Coleta de dados & 2,9 & $3,4,10$ & & & 5 \\
\hline $\begin{array}{l}\text { Após coleta de } \\
\text { dados }\end{array}$ & & 8 & & & 11 \\
\hline Todos os estágios & & 12 & 7 & & \\
\hline Não diz quando & & 3 & & & \\
\hline \hline
\end{tabular}

* numeração referente ao número atribuído ao aluno.

Tabela 10 - Dimensões e categorias obtidas a partir das respostas à pergunta número 10 do VNOS-C na primeira etapa de aplicação do questionário.

\begin{tabular}{|l|c|c|c|c|c|}
\hline Para que? & $\begin{array}{c}\text { Interpretar } \\
\text { os dados }\end{array}$ & $\begin{array}{c}\text { Elaborar } \\
\text { teorias e } \\
\text { leis }\end{array}$ & $\begin{array}{c}\text { Explicar } \\
\text { quando não } \\
\text { acham } \\
\text { respostas }\end{array}$ & $\begin{array}{c}\text { Discutir a } \\
\text { realização } \\
\text { da coleta de } \\
\text { dados }\end{array}$ & $\begin{array}{c}\text { Nenhuma } \\
\text { referência } \\
\text { ao motivo } \\
\text { do uso }\end{array}$ \\
\hline $\begin{array}{l}\text { Projeto e } \\
\text { planejamento }\end{array}$ & $3^{*}$ & 14 & & & 11,16 \\
\hline $\begin{array}{l}\text { Coleta de dados } \\
\text { Após coleta de } \\
\text { dados }\end{array}$ & $2,10,15$ & 5,8 & & & 4 \\
\hline Todos os estágios & 13 & 1 & & 13 & 6 \\
\hline Não diz quando & 9 & 7 & & & 12 \\
\hline
\end{tabular}

* numeração referente ao número atribuído ao aluno.

Tabela 11 - Dimensões e categorias obtidas a partir das respostas à pergunta número 10 do VNOS-C na segunda etapa de aplicação do questionário.

As tabelas foram construídas a partir de categorias a priori, derivadas diretamente da questão, que menciona diferentes momentos da pesquisa científica em que a imaginação e criatividade poderiam ser utilizadas pelo cientista. Trata-se da dimensão "quando?" que inserimos na $1^{\underline{a}}$ coluna à esquerda das tabelas 10 e 11.

Também foram incorporadas categorias novas, elaboradas a posteriori, ou seja, a partir das próprias respostas dos alunos. Como se trata de uma questão aberta, muitas respostas abordaram a finalidade do uso da imaginação 
e criatividade pelos cientistas, para essa análise foi criada a dimensão "Para que?" discriminada na primeira linha das tabelas 10 e 11.

As duas tabelas mostram que, na dimensão que denominamos "Quando?", os resultados apontaram que a maioria das respostas atribuiu a participação da criatividade e imaginação na produção científica nas fases de projeto e planejamento e após a coleta de dados. Como exemplo de resposta que se encaixa nessas duas categorias tomamos a do aluno 10 que disse na primeira etapa: "Sim, durante o projeto e planejamento e após a coleta de dados... a criação de situações e hipóteses que englobem os dados coletados requer um pouco de imaginação". Apenas na primeira etapa surgiram respostas que atribuíram a participação da criatividade durante a fase de coleta de dados, já na segunda etapa mais alunos disseram que ocorriam em todos os estágios. Na segunda etapa, serve de exemplo para a categoria "todos os estágios" a resposta do aluno 13, que disse: "Sim. Os cientistas utilizam criatividade em todos os estágios já que é preciso decidir como será a coleta de dados e depois, como explicar os resultados".

Quando observamos os resultados segundo outro ponto de vista, na dimensão que denominamos "Para quê?"- isto é, para quê os cientistas utilizam a imaginação e criatividade? - podemos observar que, na primeira etapa, grande parte dos alunos disse que serve para elaborar teorias e leis. $O$ aluno, na primeira etapa, teve sua resposta categorizada como "elaborar teorias e leis": "Os cientistas utilizam criatividade e imaginação no projeto, para que eles possam formular sua teoria ou lei, indo mais a fundo em coisas que outras pessoas não pensaram". Já na segunda etapa houve um aumento de alunos que tiveram suas respostas na categoria "interpretar os dados". Como exemplo temos a resposta do aluno 9, na segunda etapa: "Sim, os cientistas utilizam imaginação na hora de interpretar e ligar as evidências".

Observamos uma pequena mudança nas respostas, quando comparadas as duas etapas de respostas do VNOS-C. Em nenhuma etapa eles disseram não haver participação da imaginação e criatividade na ciência. Também observamos uma diminuição no número de alunos que passaram a creditar um papel à criatividade, principalmente, para elaborar teorias e leis.

A partir da análise da questão 3 do VOSE, que procura saber se, para os alunos, os cientistas utilizam a imaginação durante a investigação científica, 
obtivemos a Tabela 12, que traz os cálculos dos RM dos itens dessa questão nas duas etapas de aplicação do questionário.

\begin{tabular}{|c|c|c|c|c|c|c|c|}
\hline \multirow{2}{*}{ QUESTÕES } & \multirow{2}{*}{ FASE } & \multicolumn{5}{|c|}{ FREQUÊNCIA DE ALUNOS } & \multirow{2}{*}{$\mathbf{R M}$} \\
\hline & & DT & DP & $\mathbf{I}$ & CP & CT & \\
\hline \multirow{2}{*}{$\begin{array}{l}\text { 3A. Sim, a imaginação é a } \\
\text { principal fonte de inovação. }\end{array}$} & $1^{\circ}$ & 2 & 4 & 3 & 15 & 4 & 3,53 \\
\hline & $2^{\circ}$ & 0 & 7 & 2 & 15 & 4 & 3,57 \\
\hline \multirow{2}{*}{$\begin{array}{l}\text { 3B. Sim, os cientistas usam um } \\
\text { pouco da sua imaginação na } \\
\text { investigação científica. }\end{array}$} & $1^{\circ}$ & 0 & 0 & 1 & 16 & 11 & 4,35 \\
\hline & $2^{\circ}$ & 0 & 1 & 1 & 10 & 16 & 4,46 \\
\hline \multirow{2}{*}{$\begin{array}{l}\text { 3C. Não, a imaginação não é } \\
\text { coerente com os princípios } \\
\text { lógicos da ciência. }\end{array}$} & $1^{\circ}$ & 12 & 11 & 3 & 2 & 0 & 1,82 \\
\hline & $2^{\circ}$ & 14 & 12 & 1 & 1 & 0 & 1,60 \\
\hline \multirow{2}{*}{$\begin{array}{l}\text { 3D. Não, a imaginação pode se } \\
\text { tornar um meio para um cientista } \\
\text { provar seu ponto de vista a todo } \\
\text { custo. }\end{array}$} & $1^{\circ}$ & 5 & 12 & 4 & 6 & 1 & 2,5 \\
\hline & $2^{\circ}$ & 6 & 8 & 7 & 6 & 1 & 2,57 \\
\hline \multirow{2}{*}{$\begin{array}{l}\text { 3E. Não, a imaginação não tem } \\
\text { confiabilidade. }\end{array}$} & $1^{\circ}$ & 8 & 8 & 8 & 4 & 0 & 2,28 \\
\hline & $2^{\circ}$ & 11 & 12 & 1 & 4 & 0 & 1,92 \\
\hline
\end{tabular}

Tabela 12 - Ranking médio das respostas de cada um dos itens da questão 3 do VOSE.

Analisando o RM dos cinco itens nas duas etapas, percebemos que, com relação à concordância ou não dos enunciados, não houve mudanças. $\mathrm{Na}$ primeira fase os alunos já concordavam que há participação da imaginação e criatividade na ciência. Isso pode ser observado nos RM dos itens $3 A$ e 3B, que apresentam RM acima de 3. Comparando as etapas de aplicação do questionário, nesses dois itens houve um aumento do $\mathrm{RM}$, consequentemente um aumento no grau de concordância. Já com relação aos itens que não 
atribuíam a participação da criatividade e imaginação na ciência (itens 3C, 3D e 3E) observamos diminuição do RM nos itens 3C e 3E o que caracteriza uma maior discordância a essas afirmações. No item 3D observamos pequeno aumento do RM, mas seguido também de um maior número de alunos incertos com essa afirmação.

Apesar de diferenças quanto ao momento da pesquisa e ao motivo de utilizarem criatividade e imaginação, no VNOS-C todos os alunos consideraram haver participação desse aspecto na ciência. Por sua vez, na resposta ao VOSE, observamos a manutenção da opinião, porém o RM dos itens que defendiam a participação da criatividade e imaginação na ciência aumentou e o RM de dois dos itens (3C e 3E) que não aceitavam essa participação diminuiu.

Não foi possível realizar qualquer relação entre as respostas dos alunos e dados obtidos a partir das entrevistas com os professores. Sobre esse aspecto da NdC o professor Rui Murieta afirma estimular a utilização da criatividade e imaginação em sala de aula a partir da utilização de análises de filmes. Sobre isso ele disse (turno E24):

Como eu não posso, na Antropologia, dar grandes etnografias para eles lerem, eu faço, nitidamente, eles fazerem uma análise antropológica de grandes filmes. Com uma narrativa, ai vem o estímulo da criatividade, o estímulo... o estranhamento intelectual.

\subsubsection{O conhecimento científico está inserido na cultura}

A partir da análise das respostas à questão 11 do VNOS-C, as Tabelas 13 e 14 foram construídas. O aluno 17 não respondeu essa questão na primeira fase de aplicação do questionário, por isso, para essa questão, sua resposta não foi considerada na segunda fase. Segundo o referencial do

capítulo 1 e da seção 2.3.4, buscávamos que os alunos possuíssem a compreensão que a ciência é uma construção humana e que se desenvolve dentro de uma cultura. 


\begin{tabular}{||l|c|c|c|c|c||}
\hline Porque & $\begin{array}{c}\text { é uma } \\
\text { construção } \\
\text { humana e } \\
\text { tem } \\
\text { interesses } \\
\text { humanos }\end{array}$ & $\begin{array}{c}\text { analisa } \\
\text { fenômenos } \\
\text { naturais e } \\
\text { dados }\end{array}$ & $\begin{array}{c}\text { exige a } \\
\text { interpretação } \\
\text { de dados }\end{array}$ & $\begin{array}{c}\text { por } \\
\text { causa } \\
\text { do } \\
\text { acesso }\end{array}$ & $\begin{array}{c}\text { Não } \\
\text { argumenta }\end{array}$ \\
\hline é universal & $1,3,4,5,12$ & & 7,15 & 13 \\
\hline $\begin{array}{l}\text { reflete } \\
\text { valores }\end{array}$ & $2,8,9,10$ & & 11 & 6 & 14 \\
\hline $\begin{array}{l}\text { refletia } \\
\text { valores, } \\
\text { mas agora } \\
\text { é universal }\end{array}$ & & & & 16 & \\
\hline
\end{tabular}

Tabela 13 - Dimensões e categorias obtidas a partir das respostas à pergunta número 11 do VNOS-C na primeira etapa de aplicação do questionário.

\begin{tabular}{||l|c|c|c|c|c||}
\hline Porque & $\begin{array}{c}\text { é uma } \\
\text { construção } \\
\text { humana e } \\
\text { tem } \\
\text { interesses } \\
\text { humanos }\end{array}$ & $\begin{array}{c}\text { analisa } \\
\text { fenômenos } \\
\text { naturais e } \\
\text { dados }\end{array}$ & $\begin{array}{c}\text { exige a } \\
\text { interpretação } \\
\text { de dados }\end{array}$ & $\begin{array}{c}\text { por } \\
\text { causa } \\
\text { do } \\
\text { acesso }\end{array}$ & $\begin{array}{c}\text { Não } \\
\text { argumenta }\end{array}$ \\
\hline é universal & $1,12,16$ & & 1 & 7 \\
\hline $\begin{array}{l}\text { reflete } \\
\text { valores }\end{array}$ & $\begin{array}{c}2,3,5,6,8, \\
9,10,11, \\
13,14\end{array}$ & 15 & & & \\
\hline $\begin{array}{l}\text { refletia } \\
\text { valores, } \\
\text { mas agora } \\
\text { é universal }\end{array}$ & & & & & 4 \\
\hline
\end{tabular}

Tabela 14 - Dimensões e categorias obtidas a partir das respostas à pergunta número 11 do VNOS-C na segunda etapa de aplicação do questionário.

A partir das Tabelas 13 e 14 apresentadas, observamos as dimensões "a ciência" e "porque". Na dimensão "a ciência" foram elaboradas duas categorias que permitiram dividir as respostas entre os que tinham uma posição de que a ciência é universal, isso é, se ela não é afetada por valores socioculturais, ou os que adotaram uma posição de que a ciência reflete valores socioculturais. Uma nova categoria dessa dimensão foi obtida a 
posteriori, já que alguns alunos responderam que a ciência antigamente refletia valores socioculturais, mas acreditam que atualmente a ciência seja universal.

$\mathrm{Na}$ dimensão "porque" todas as categorias foram construídas a posteriori. Nessa dimensão buscamos averiguar o argumento utilizado pelo aluno para defender sua resposta. A categoria "é uma construção humana e tem interesses humanos" foi obtida a partir de respostas exclusivamente dadas para aqueles que acreditavam na ciência sendo influenciada por valores socioculturais. Um exemplo de resposta dada, que se encaixa nessa categoria é a do aluno 10, na primeira etapa: "A ciência, como todo o resto do mundo, não é imparcial. Ela é feita pelos homens que possuem diferentes características e formações individuais, que farão parte da construção de suas hipóteses e teorias".

Em contra partida, a categoria "analisa fenômenos naturais e dados" foi obtida apenas de respostas que defendiam que a ciência é universal. Os alunos 1 e 12 se encaixaram nessa categoria nas duas etapas do questionário. O aluno 1 na segunda fase respondeu: "A ciência não está impregnada de valores culturais pois as conclusões de um cientista válidas para todo 0 planeta".

Como podemos observar, a categoria "exige a interpretação de dados" só surgiu devido a resposta do aluno 11 na primeira etapa. Ele respondeu: "a) Porque a ciência exige interpretações de dados". Pelo fato de ele ter colocado "a)" para iniciar sua resposta acreditamos que ele tenha respondido ao item a da questão 11 do VNOS-C, que era exclusivo para aqueles que acreditavam que a ciência reflete valores socioculturais.

Acreditamos que a categoria "por causa do acesso" surgiu devido a um equívoco dos alunos quanto ao termo universal. Esses alunos atribuíram ao termo universal o significado de que a ciência possa ser ou não acessível a todos. Os alunos 7 e 15 da primeira etapa e 0 aluno 1 da segunda etapa afirmaram que a ciência deve estar disponível a todos. Como exemplo o aluno 15 na primeira etapa respondeu: "Acredito que a ciência deveria ser algo universal, todos os países em todo mundo deve ter acesso aos mesmos dados e conhecimentos". O aluno 6 , na primeira etapa, adotou uma postura de que a ciência não está disponível para todos. A resposta desse aluno foi: "A ciência reflete valores sociais e culturais porque ela é muito pouco acessível". 
Alguns alunos não argumentaram o motivo da sua posição e por isso se encaixaram na categoria "não argumenta".

Observamos uma mudança nas respostas, quando comparadas as duas etapas de respostas do VNOS-C. Um maior número de alunos passa a se encaixar nas categorias que defendem que a ciência é influenciada pelo contexto sociocultural.

A partir da análise da questão 2 do VOSE, que questiona se as investigações científicas são influenciadas por valores socioculturais, elaboramos a Tabela 15, que são os cálculos dos RM dos itens dessa questão nas duas etapas de aplicação do questionário.

\begin{tabular}{|c|c|c|c|c|c|c|c|}
\hline \multirow{2}{*}{ QUESTÕES } & \multirow{2}{*}{ FASE } & \multicolumn{5}{|c|}{ FREQUÊNCIA DE ALUNOS } & \multirow{2}{*}{$\mathbf{R M}$} \\
\hline & & DT & DP & I & CP & CT & \\
\hline \multirow{2}{*}{$\begin{array}{l}\text { 2A. Sim, valores socioculturais } \\
\text { influenciam a direção e os } \\
\text { tópicos } \\
\text { científica. }\end{array}$} & $1^{\circ}$ & 2 & 2 & 1 & 14 & 9 & 3,92 \\
\hline & $2^{\circ}$ & 0 & 2 & 1 & 9 & 16 & 4,4 \\
\hline \multirow{2}{*}{$\begin{array}{l}\text { 2B. Sim, porque os cientistas } \\
\text { que realizam investigações } \\
\text { científicas são influenciados por } \\
\text { valores socioculturais. }\end{array}$} & $1^{\circ}$ & 2 & 3 & 1 & 14 & 8 & 3,82 \\
\hline & $2^{\circ}$ & 1 & 3 & 3 & 9 & 12 & 4 \\
\hline \multirow{2}{*}{$\begin{array}{l}\text { 2C. Não, cientistas com boa } \\
\text { formação permanecerão isentos } \\
\text { de valores quando realizarem } \\
\text { suas pesquisas. }\end{array}$} & $1^{\circ}$ & 8 & 9 & 6 & 5 & 0 & 2,28 \\
\hline & $2^{\circ}$ & 14 & 7 & 0 & 6 & 1 & 2,03 \\
\hline \multirow{2}{*}{$\begin{array}{l}\text { 2D. Não, porque a ciência requer } \\
\text { objetividade, o que é contrário à } \\
\text { subjetividade dos valores } \\
\text { socioculturais. }\end{array}$} & $1^{\circ}$ & 5 & 8 & 4 & 8 & 3 & 2,85 \\
\hline & $2^{\circ}$ & 7 & 8 & 1 & 10 & 2 & 2,71 \\
\hline
\end{tabular}

Tabela 15 - Ranking médio das respostas de cada um dos itens da questão 2 do VOSE.

A análise do RM dos quatro itens, nas duas etapas, permite perceber que os alunos mantiveram a opinião com relação aos enunciados. Mesmo assim houve um aumento do RM nos itens $2 \mathrm{~A}$ e 2B e diminuição do RM nos itens $2 \mathrm{C}$ e $2 \mathrm{D}$. 
Se observarmos o número de respostas no item $2 \mathrm{~A}$ veremos que passou de 9 para 16 o número de alunos que concordam totalmente que "valores socioculturais influenciam a direção e os tópicos de investigação científica".

$\mathrm{O}$ contrário acontece com o item $2 \mathrm{C}$, que afirma que "cientistas com boa formação permanecerão isentos de valores quando realizarem suas pesquisas". Na segunda fase, $50 \%$ dos alunos discordaram totalmente dessa afirmação.

Como pode ser observado na seção 3.3, onde estão descritas as entrevistas com os professores, o professor Paulo Sano destacou a preocupação intencional de enfatizar, em sala de aula, que a ciência, por ser uma produção humana, está sujeita a um contexto social, cultural e histórico. Essa ênfase pode ter proporcionado a lembrança declarada pelos três alunos sobre esse aspecto da $\mathrm{NdC}$, ao responderem à questão 7 do questionários sociocultural e de opinião sobre a importância da NdC.

Para esse aspecto um maior número de alunos adotou uma posição a favor de uma influência sociocultural na ciência. Com o questionário VNOS-C observamos, na segunda etapa, que mais alunos declararam que a ciência reflete valores socioculturais e é uma construção humana. A análise das respostas ao questionário VOSE também permitiu observar essa mudança. O aumento do RM nos itens que afirmam haver participação de influências socioculturais na ciência e uma diminuição do RM nos itens que defendem que a influência sociocultural não faz parte da ciência, apontam para uma maior aceitação da influência de fatores socioculturais na ciência, pelos alunos.

\subsubsection{O conhecimento científico é determinado por teorias}

Com base no referencial do capítulo 1 e da seção 2.3.4, para esse aspecto da $\mathrm{NdC}$, buscamos investigar se os alunos reconheciam a influência dos conhecimentos prévios e a escolha de teorias, pelos cientístas, na construção do conhecimento científico. Para isso utilizamos a questão 9 do VNOS-C e os itens 8A, 8C, 15D, 15E, 15H E 15I do VOSE.

Nas Tabelas 16 e 17 podemos observar as categorias criadas a partir das respostas dos alunos à questão 9 do VNOS-C, na primeira e segunda etapas, respectivamente. 


\begin{tabular}{||l|c|c||}
\hline \multicolumn{1}{|c|}{ Pesquisadores analisam } & \multicolumn{1}{|c|}{$\begin{array}{c}\text { dados } \\
\text { A construção do } \\
\text { conhecimento é influenciada } \\
\text { pelo(a) }\end{array}$} & $\begin{array}{c}\text { dados } \\
\text { diferentes ou } \\
\text { insuficientes }\end{array}$ \\
\hline $\begin{array}{l}\text { formação de cada } \\
\text { pesquisador }\end{array}$ & 13 & \\
\hline $\begin{array}{l}\text { pensamento e/ou } \\
\text { interpretação de cada } \\
\text { pesquisador }\end{array}$ & $\begin{array}{c}1,2,4,7, \\
8,11,15, \\
17\end{array}$ & \\
$\begin{array}{l}\text { fato dos dados observados } \\
\text { terem ocorrido há muito } \\
\text { tempo }\end{array}$ & $6,9,14$ & \\
\hline $\begin{array}{l}\text { foco do pesquisador } \\
\text { Não faz referência }\end{array}$ & $3,10,12$ & 5,16 \\
\hline
\end{tabular}

Tabela 16 - Dimensões e categorias obtidas a partir das respostas à pergunta número 9 do VNOS-C na primeira etapa de aplicação do questionário.

\begin{tabular}{||l|c|c||}
\hline \multicolumn{1}{|c|}{$\begin{array}{c}\text { Pesquisadores analisam } \\
\text { A construção do } \\
\text { conhecimento é influenciada } \\
\text { pelo(a) }\end{array}$} & $\begin{array}{c}\text { mesmos } \\
\text { dados }\end{array}$ & $\begin{array}{c}\text { dados } \\
\text { diferentes ou } \\
\text { insuficientes }\end{array}$ \\
$\begin{array}{l}\text { formação de cada } \\
\text { pesquisador }\end{array}$ & $1,2,3,14$ & \\
\hline $\begin{array}{l}\text { pensamento e/ou } \\
\text { interpretação de cada } \\
\text { pesquisador }\end{array}$ & $\begin{array}{c}3,7,9,11, \\
15\end{array}$ & \\
\hline $\begin{array}{l}\text { fato dos dados observados } \\
\text { terem ocorrido há muito } \\
\text { tempo }\end{array}$ & $6,8,16$ & \\
\hline $\begin{array}{l}\text { foco do pesquisador } \\
\text { Não faz referência }\end{array}$ & 3,4 & $5,12,13$, \\
\hline
\end{tabular}

Tabela 17 - Dimensões e categorias obtidas a partir das respostas à pergunta número 9 do VNOS-C na segunda etapa de aplicação do questionário. 
$\mathrm{Na}$ questão 9 do VNOS-C todas as categorias foram elaboradas a posteriori. As duas dimensões criadas para análise das respostas foram: "pesquisadores analisam" e "a construção do conhecimento depende". A dimensão "pesquisadores analisam" surgiu devido a alguns alunos declararem que os pesquisadores poderiam ter analisado os mesmos dados ou dados diferentes ou insuficientes para chegarem às suas conclusões. Essas respostas apareceram mesmo constando na pergunta do VNOS-C, em negrito, que os grupos de pesquisadores utilizaram o mesmo conjunto de dados. Os alunos que não fizeram nenhuma referência aos dados analisados pelos pesquisadores foram considerados como tendo entendido a informação contida na pergunta. A dimensão "a construção do conhecimento é influenciada" traz as justificativas dos alunos para a forma como os cientistas obtiveram diferentes conclusões para o fenômeno relatado na questão.

A categoria "não faz referência" foi construída a partir de respostas que não deixavam clara a participação ou não de influências pessoais na ciência.

A categoria "pelo fato dos dados observados terem ocorrido há muito tempo" foram obtidas a partir de respostas que atribuíram à falta de dados o fato dos pesquisadores chegarem a diferentes conclusões. Consideramos que os alunos que se encaixaram nessas categorias adotaram uma posição na qual os conhecimentos científicos prévios e escolhas do pesquisador não influenciam na elaboração das teorias. Como exemplo de resposta que se encaixa na categoria "dados diferentes ou insuficientes", temos a resposta do aluno 5, na primeira etapa: "Conclusões diferentes são formuladas quando os dados são insuficientes para se comprovar definitivamente uma teoria".

Observamos, na primeira fase, que muitos alunos declararam que a ciência é subjetiva por causa "do pensamento e/ou interpretação de cada pesquisador". Esse número diminui na segunda etapa, porém continuou sendo a categoria com maior número de respostas. Já, na segunda etapa, um maior número de alunos afirma ser a subjetividade influenciada pela "formação de cada pesquisador" ou pelo "foco do pesquisador". A resposta do aluno 2, na segunda etapa, serve de exemplo para a categoria "formação de cada pesquisador": "A mesma informação pode ser interpretada de diferentes modos, uma vez que a pesquisa é realizada por seres humanos com diferentes metodologias de observação e visões de mundo". Como exemplo de resposta 
da categoria "foco do pesquisador" temos o aluno 4, na segunda etapa, que declarou: "Análises diferentes de evidências iguais podem gerar teorias diferentes uma vez que cada grupo pode ter se focado em um aspecto diferente".

O aluno 3, na segunda etapa, se encaixou em três categorias (formação, interpretação e foco do pesquisador). Esse aluno afirmou: "A formulação de diferentes hipóteses podem ocorrer para cientistas com uma base de formação diferente bem como um nível de imaginação díspare. Além disso, podem considerar qualitativamente diferentes evidências, ou seja, dar mais valor a uma do que outra".

Com relação ao VOSE, o aspecto "o conhecimento científico é determinado por teorias" foi analisado por meio dos itens 8A, 8C, 15D, 15E, $15 \mathrm{H}$ e $15 \mathrm{l}$ por tratarem de maneira mais direta esse aspecto.

Os itens $8 \mathrm{~A}$ e $8 \mathrm{C}$ buscam saber a opinião dos alunos com relação à influência de crenças pessoais nas observações dos cientistas. A questão 8 é a seguinte: "As observações dos cientistas são influenciadas pelas crenças pessoais (por exemplo, experiências pessoais, as pressuposições); portanto, eles não podem fazer as mesmas observações para o mesmo experimento". 0 item 8A possui uma afirmação que aceita a influência das crenças pessoais dos cientistas em suas observações. No item 8C a afirmação apresenta uma posição na qual os valores pessoais são deixados de lado devido à formação científica.

Nos itens da questão 15 do VOSE os alunos opinaram com qual ponto de vista, da perspectiva da $\mathrm{NdC}$, entre os pesquisadores $\mathrm{A}$ e $\mathrm{B}$ do texto apresentado, eles concordam. A questão 15 é: "Do ponto de vista da natureza da ciência, qual forma de pensar, entre os pesquisadores $A$ e $B$, você concorda?". O item 15D é uma afirmação que concorda com o pesquisador $A$, o item 15E concorda com o pesquisador $\mathrm{B}$, o item $15 \mathrm{H}$ concorda com ambos $\mathrm{e}$ o item 15I discorda de ambos os pesquisadores. abaixo:

A partir das respostas dos alunos e calculo do RM foi obtida a Tabela 18, 


\begin{tabular}{|c|c|c|c|c|c|c|c|}
\hline \multirow{2}{*}{ QUESTÕES } & \multirow{2}{*}{ FASE } & \multicolumn{5}{|c|}{$\begin{array}{c}\text { FREQUÊNCIA DE } \\
\text { ALUNOS }\end{array}$} & \multirow{2}{*}{$\mathbf{R M}$} \\
\hline & & DT & DP & I & CP & CT & \\
\hline \multirow{2}{*}{$\begin{array}{l}\text { 8A. As observações serão } \\
\text { diferentes, porque crenças } \\
\text { diferentes levam a diferentes } \\
\text { expectativas que influenciam a } \\
\text { observação. }\end{array}$} & $1^{\circ}$ & 4 & 6 & 2 & 14 & 2 & 3,14 \\
\hline & $2^{\circ}$ & 5 & 8 & 2 & 12 & 1 & 2,85 \\
\hline \multirow{2}{*}{$\begin{array}{l}\text { 8C. As observações serão as } \\
\text { mesmas, porque através da } \\
\text { formação científica os cientistas } \\
\text { podem abandonar os valores } \\
\text { pessoais para realizar } \\
\text { observações objetivas. }\end{array}$} & $1^{\circ}$ & 5 & 7 & 3 & 12 & 1 & 2,89 \\
\hline & $2^{\circ}$ & 5 & 5 & 2 & 16 & 0 & 3,03 \\
\hline \multirow{2}{*}{$\begin{array}{l}\text { 15D. A - Respeitar a diversidade } \\
\text { entre os seres humanos. }\end{array}$} & $1^{\circ}$ & 0 & 1 & 1 & 5 & 21 & 4,64 \\
\hline & $2^{\circ}$ & 0 & 0 & 1 & 5 & 22 & 4,75 \\
\hline \multirow{2}{*}{$\begin{array}{l}\text { 15E. B }- \text { A investigação } \\
\text { científica } \\
\text { completamente independente da } \\
\text { crença pessoal. }\end{array}$} & $1^{\circ}$ & 5 & 17 & 3 & 3 & 0 & 2,14 \\
\hline & $2^{\circ}$ & 8 & 6 & 4 & 7 & 3 & 2,67 \\
\hline \multirow{2}{*}{$\begin{array}{l}\text { 15H. Ambos, desde que tenham } \\
\text { espírito científico r serão } \\
\text { influenciados por valores } \\
\text { pessoais. }\end{array}$} & $1^{\circ}$ & 0 & 4 & 3 & 17 & 4 & 3,75 \\
\hline & $2^{\circ}$ & 1 & 3 & 3 & 14 & 7 & 3,82 \\
\hline \multirow{2}{*}{$\begin{array}{l}\text { 15l. Nenhum, ninguém é objetivo } \\
\text { o suficiente a ponto de não ser } \\
\text { influenciado por suas crenças e } \\
\text { valores pessoais. }\end{array}$} & $1^{\circ}$ & 0 & 6 & 2 & 11 & 9 & 3,82 \\
\hline & $2^{\circ}$ & 1 & 3 & 3 & 7 & 14 & 4,07 \\
\hline
\end{tabular}

Tabela 18 - Ranking Médio das respostas aos itens 8A, 8C, 15D, 15E, 15H, 15I do VOSE.

A afirmação que introduz a questão 8 do VOSE diz que os cientistas são influenciados pelas crenças pessoais. Acreditávamos que essa afirmação poderia ter influenciado as respostas dos alunos. Porém observamos, quando comparadas as duas etapas, que os alunos passaram a adotar uma posição em que as crenças pessoais possuem uma menor influência nas observações. Isso pode ser observado pela diminuição do RM no item 8A, em que os alunos passaram a discordar da afirmação de que crenças diferentes provocam observações diferentes. Também podemos observar essa mudança no item 
8C, no qual os alunos passaram a concordar com a afirmação de que os cientistas, através da formação científica, podem abandonar os valores pessoais para realizar uma observação objetiva.

Já para os itens 15D e 15E, os alunos concordaram, nas duas etapas, com o pesquisador A (RM maior que 3), que possui uma posição em que os fatores pessoais influenciam a pesquisa, e discordaram do pesquisador $B$ (RM menor que 3), o qual afirma que a crença pessoal não deve interferir na pesquisa científica. Para esses itens os alunos adotaram uma postura de que as crenças pessoais fazem parte da ciência.

Os dois itens finais $15 \mathrm{H}$ e $15 \mathrm{l}$ apresentaram RM acima de 3 e aumentaram na segunda etapa. Mesmo sendo o item $15 \mathrm{H}$ de concordância com os dois pesquisadores e o item 151 apresentando uma posição de discordância com a postura dos dois pesquisadores, essas questões não se contrapõem. Os argumentos que defendem essas duas afirmações são a favor de uma postura em que a crença pessoal faz parte da ciência.

Quando comparados os RM das duas etapas observamos uma incoerência nas respostas, já que nos itens $8 \mathrm{~A}$ e $8 \mathrm{C}$ os alunos passaram a adotar uma opinião contrária à influência de valores pessoais na ciência e nos itens 15D,15E, 15H, e $15 \mathrm{I}$ os alunos deram respostas aceitando as influências pessoais na construção do conhecimento científico. Durante as entrevistas os professores não destacaram terem trabalhado de uma forma explícita o aspecto de que a ciência é determinada por teorias. Observamos que as respostas dos alunos, obtidas por meio dos dois questionários, corroboram essa informação proveniente das entrevistas dos professores. Como apresentado na análise acima, não percebemos mudanças significativas de opinião dos alunos quando comparadas as duas etapas de aplicação dos questionários.

\subsubsection{Leis e teorias científicas}

No questionário VNOS-C o tema leis e teorias científicas é investigado, de forma direta, na questão 6 . Essa questão busca saber se o aluno acredita na existência de diferenças entre leis e teorias científicas. Já o questionário VOSE investiga sobre a diferença entre leis e teorias científicas na questão 7 . Segundo o referencial do capítulo 1 e da seção 2.3.4, buscamos investigar se 
os alunos reconheciam que leis e teorias científicas: não são verdades absolutas; são formas diferentes de conhecimento; não há uma hierarquia entre elas; e que uma não se transforma na outra devido ao acúmulo de evidências

A análise das respostas à questão 6 do VNOS-C foi realizada a partir de duas dimensões. Em uma das dimensões, que denominamos "leis e teorias são" as respostas dos alunos foram colocadas nas categorias "diferentes" ou "iguais". Nela buscamos diferenciar as respostas em dois grupos: os que acreditam que leis e teorias são formas de conhecimento iguais e os que acreditam que são formas de pensamento diferentes. A partir da segunda dimensão, obtida a posteriori, obtivemos seis categorias e foi denominada "argumentaram que", onde analisamos o argumento dos alunos para defender suas opiniões. Seguem abaixo as Tabelas 19 e 20 produzidas a partir da análise das respostas dos alunos nas duas etapas:

\begin{tabular}{|c|c|c|}
\hline $\begin{array}{l}\text { Leis e teorias são } \\
\text { Argumentaram que }\end{array}$ & Diferentes & Iguais \\
\hline $\begin{array}{l}\text { 1- As leis são comprovadas e } \\
\text { também mais confiáveis e/ou } \\
\text { aceitas que as teorias }\end{array}$ & $\begin{array}{c}1,2,3,4,6 \\
7,8,9,10 \\
11,12,13 \\
14,16\end{array}$ & \\
\hline $\begin{array}{l}\text { 2- As teorias se transformam em } \\
\text { leis após vários estudos e } \\
\text { experiências }\end{array}$ & 15 & \\
\hline $\begin{array}{l}\text { 3- Teorias são mais universais e } \\
\text { as leis mais específicas }\end{array}$ & & \\
\hline $\begin{array}{l}\text { 4- As leis se aplicam a um } \\
\text { número maior de eventos }\end{array}$ & & \\
\hline $\begin{array}{l}\text { 5- As leis possibilitam a criação } \\
\text { de teorias }\end{array}$ & 5 & \\
\hline $\begin{array}{l}\text { 6- As leis e teorias podem ser } \\
\text { refutadas }\end{array}$ & & 17 \\
\hline
\end{tabular}

Tabela 19 - Dimensões e categorias obtidas a partir das respostas à pergunta número 6 do VNOS-C na primeira etapa de aplicação do questionário. 


\begin{tabular}{|c|c|c|}
\hline $\begin{array}{l}\text { Leis e teorias são } \\
\text { Argumentaram que }\end{array}$ & Diferentes & Iguais \\
\hline $\begin{array}{l}\text { 1- As leis são comprovadas e } \\
\text { também mais confiáveis e/ou } \\
\text { aceitas que as teorias }\end{array}$ & $\begin{array}{c}1,3,4,6,9 \\
11,12,16\end{array}$ & \\
\hline $\begin{array}{l}\text { 2- As teorias se transformam em } \\
\text { leis após vários estudos e } \\
\text { experiências }\end{array}$ & 15 & \\
\hline $\begin{array}{l}\text { 3- Teorias são mais universais e } \\
\text { as leis mais específicas }\end{array}$ & $2,7,13$ & \\
\hline $\begin{array}{l}\text { 4- As leis se aplicam a um } \\
\text { número maior de eventos }\end{array}$ & 14,17 & \\
\hline $\begin{array}{l}\text { 5- As leis possibilitam a criação } \\
\text { de teorias }\end{array}$ & 8 & \\
\hline $\begin{array}{l}\text { 6- As leis e teorias podem ser } \\
\text { refutadas }\end{array}$ & 5,10 & \\
\hline
\end{tabular}

Tabela 20 - Dimensões e categorias obtidas a partir das respostas à pergunta número 6 do VNOS-C na segunda etapa de aplicação do questionário.

Com relação à dimensão "leis e teorias são", observamos que apenas o aluno 17, na primeira etapa, respondeu que leis e teorias são formas de pensamento iguais. Todas as outras respostas dos alunos se encaixaram na categoria "diferentes". Esperávamos que os alunos concordassem que leis e teorias são formas de pensamento diferentes, porém observamos que parte dos alunos teve suas respostas colocadas na categoria "diferente" devido a atribuição de uma hierarquia entre essas duas formas de conhecimento. Essa hierarquia não é aceita, segundo os referenciais teóricos que discutimos no capítulo 1, e só pode ser observado a partir das categorias obtidas por meio da dimensão "argumentam que".

As categorias criadas a partir das respostas dos alunos, para a dimensão "argumentaram que", referentes às duas etapas de aplicação dos questionários, nos permitiram observar que grande parte dos alunos adotou uma posição que se encaixa na categoria "as leis são comprovadas e também mais confiáveis e/ou aceitas que as teorias". Já na segunda etapa, um menor número de alunos se encaixou nesta categoria. As respostas que se encaixam nessa categoria não estão de acordo com os referenciais teóricos aqui discutidos, já que os alunos distinguem as leis como uma forma de 
pensamento comprovada. Como exemplo de resposta dessa categoria temos a resposta do aluno 2, na primeira etapa, que diz: "a teoria não foi totalmente comprovada, enquanto a lei científica foi".

Apenas o aluno 15, nas duas etapas de aplicação do questionário, declarou que as teorias se transformam em leis após vários estudos e experiências. Na primeira etapa, esse aluno disse: "lei científica é uma teoria que conseguiu ser comprovada através de experimentos". Esta forma de pensar também não está de acordo com a epistemologia atual.

As respostas da segunda etapa ainda proporcionaram a criação de duas categorias. Numa delas, as respostas de dois alunos foram categorizadas como: "leis se aplicam a um número maior de eventos". Nessa categoria destacamos a resposta do aluno 17, que afirmou: "uma lei é mais ampla, costuma explicar mais elementos que uma teoria e, por essa razão, uma lei pode surgir de um conjunto de teorias". Na outra categoria "teorias são mais universais e as leis mais específicas", que apareceu apenas na segunda etapa, as respostas de três alunos se encaixaram. Como exemplo de resposta dessa categoria, temos a do aluno 2, na segunda etapa: "enquanto uma lei descreve um padrão considerado pontual [...] uma teoria descreve alguns padrões que são considerados universais". Com base nas respostas que se encaixaram nessas duas categorias, observamos existir certa hierarquia no modo pelo qual os alunos concebem leis e teorias. Isso está em desacordo com a literatura discutida no capítulo 1 e na seção 2.3.4, em que leis são afirmações ou descrições das relações entre fenômenos observados, enquanto teorias são explicações inferidas para fenômenos observáveis.

A partir das respostas do aluno 5, na primeira etapa, e do aluno 8, na segunda etapa, foi possível criar a categoria "as leis possibilitam a criação de teorias", que consideramos estar em desacordo com os referenciais utilizados (uma não se transforma na outra devido ao acumulo de evidências). O aluno 5, na primeira etapa, declarou: "as leis científicas regem o funcionamento de uma ciência, possibilitando a criação de teorias científicas".

O aluno 17 na primeira etapa e os alunos 5 e 10 ainda declararam que as leis e teorias podem ser refutadas. As respostas destes alunos estão de acordo com nossos referenciais teóricos que afirmam, que as leis científicas não são verdades absolutas (McComas, 1998). 
Quando comparadas as duas etapas observamos que na segunda etapa muitos alunos mudaram suas respostas, assumindo posições diferentes. Quase todos os alunos declararam que leis e teorias são formas de conhecimento diferentes. Mesmo assim, na segunda etapa, muitos alunos ainda declararam que as leis possuem mais credibilidade do que as teorias.

No questionário VOSE é a questão 7 que investiga a opinião dos alunos sobre a diferença entre leis e teorias. A questão 7 do VOSE é uma afirmação e diz: "Em comparação com as leis, as teorias têm menos evidências para apoiálas". A partir do cálculo do RM obtido a partir das respostas foi possível construir a Tabela 21 abaixo.

\begin{tabular}{|c|c|c|c|c|c|c|c|}
\hline \multirow{2}{*}{ QUESTÕES } & \multirow{2}{*}{ FASE } & \multicolumn{5}{|c|}{ FREQUÊNCIA DE ALUNOS } & \multirow{2}{*}{$\mathbf{R M}$} \\
\hline & & DT & DP & $\mathbf{I}$ & CP & CT & \\
\hline \multirow{2}{*}{$\begin{array}{l}\text { 7A. Sim, as teorias não são tão } \\
\text { definidas como as leis. }\end{array}$} & $1^{\circ}$ & 4 & 3 & 3 & 10 & 8 & 3,53 \\
\hline & $2^{\circ}$ & 5 & 4 & 1 & 12 & 6 & 3,35 \\
\hline \multirow{2}{*}{$\begin{array}{l}\text { 7B. Sim, se uma teoria resiste a } \\
\text { muitos testes ela acabará por se } \\
\text { tornar uma lei; portanto, uma lei } \\
\text { tem mais evidências que a } \\
\text { fundamentam. }\end{array}$} & $1^{\circ}$ & 3 & 2 & 4 & 10 & 9 & 3,71 \\
\hline & $2^{\circ}$ & 2 & 4 & 6 & 9 & 7 & 3,53 \\
\hline \multirow{2}{*}{$\begin{array}{l}\text { 7C. Não exatamente; algumas } \\
\text { teorias têm mais evidências que } \\
\text { as fundamentam do que } \\
\text { algumas leis. }\end{array}$} & $1^{\circ}$ & 2 & 7 & 10 & 6 & 3 & 3,03 \\
\hline & $2^{\circ}$ & 2 & 6 & 6 & 11 & 3 & 3,25 \\
\hline \multirow{2}{*}{$\begin{array}{l}\text { 7D. Não, teorias e leis são } \\
\text { diferentes tipos de ideias. Elas } \\
\text { não podem ser comparadas. }\end{array}$} & $1^{\circ}$ & 10 & 8 & 5 & 4 & 1 & 2,21 \\
\hline & $2^{\circ}$ & 5 & 5 & 11 & 3 & 4 & 2,85 \\
\hline
\end{tabular}

Tabela 21 - Ranking médio das respostas de cada um dos itens da questão 7 do VOSE.

Nessa questão, que busca saber se os alunos acreditam que teorias possuem menos evidências que leis para apoiá-las, não observamos mudanças quanto à concordância dos alunos. Porém a diminuição dos RM nos 
itens 7A e 7B aponta para uma diminuição na crença de que existe uma hierarquia entre teorias e leis. Já o RM do item 7C aumentou, o que aponta que mais alunos mostraram concordar que algumas teorias podem ter mais evidências que as leis. O RM do item 7D também aumentou e isso aponta para que os alunos concordam mais com a afirmação de que teorias e leis são diferentes tipos de ideias.

Quando comparadas as duas etapas, os alunos que responderam o VOSE continuam discordando da posição epistemológica de que teorias e leis são diferentes tipos de conhecimento, mas o aumento do RM aponta para um maior número de alunos aceitando essa afirmação.

A maioria das respostas, tanto dos alunos que responderam o VNOS-C quanto os que responderam o VOSE, no momento da pesquisa, não está de acordo com o que é aceito atualmente na filosofia das ciências. A partir das respostas é possível observar, por exemplo, que grande parte dos alunos acredita em uma hierarquia entre leis e teorias científicas. Também observamos, como McComas (2003), que muitos ainda acreditam erroneamente que as teorias se transformam em leis como se fosse um processo de maturação. Este tipo de pensamento pode levar ao equívoco de que as leis são mais importantes do que as teorias. A falta de atenção para a distinção entre termos compromete a aprendizagem do aluno sobre o modo como o conhecimento científico é construído (McComas, 2003).

Mesmo sendo observado pelo professor Rui Murieta que a falta de compreensão por parte dos alunos de que a teoria já é um momento avançado do processo científico, e não uma hipótese ou especulação (turno E20, explicitado no tópico 3.3 da dissertação), os professores não declararam ter trabalhado esse aspecto da NdC em sala de aula. Por não ter sido trabalhado em sala de aula de forma explícita não era de se esperar que houvesse mudanças na posição epistemológica por parte dos alunos. Porém é estranho observar que esse aspecto da $\mathrm{NdC}$ foi o mais lembrado pelos alunos ao longo do semestre. Cinco alunos declararam ter lembrado sobre a definição de leis, teorias e também hipóteses.

Ernst Mayr também observou que a maior parte dos alunos de biologia possui dificuldades para diferenciar lei e teoria e acredita que esse resultado seja decorrente de que as teorias nas ciências biológicas sejam principalmente 
baseadas em conceitos, os quais possuem um papel muito maior que o das leis na formação de teorias biológicas. Para ele, as maiores contribuições para a formação de uma nova teoria biológica vêm da descoberta de novos fatos, a partir de observações e do desenvolvimento de novos conceitos (Mayr, 2008, p. 94-96).

\subsubsection{O conhecimento científico é provisório}

Sobre esse aspecto da $\mathrm{NdC}$, analisamos as respostas referentes à questão 7 do VNOS-C e as respostas referentes à questão 4 do VOSE. A nossa expectativa, segundo o referencial do capítulo 1 e da seção 2.3.4, era de que os alunos apenas concordassem que a ciência está em constante mudança é não é uma forma de conhecimento definitivo.

A análise das respostas ao VNOS-C foi realizada a partir de duas dimensões, obtidas a priori. Foi obtida a dimensão "mudam porque", na qual buscamos as justificativas dos alunos para mudança de teorias, e a outra dimensão "aprendemos para" surgiu a partir do item b2, para a qual buscamos categorizar as repostas dos alunos com base nos argumentos utilizados para justificar a necessidade de aprendermos as teorias. Abaixo estão apresentadas as Tabelas 22 e 23 geradas.

\begin{tabular}{|c|c|c|c|}
\hline $\begin{array}{l}\text { Mudam porque } \\
\text { Aprendemos para }\end{array}$ & $\begin{array}{l}\text { métodos de } \\
\text { investigação e } \\
\text { as tecnologias } \\
\text { mudam } \\
\text { permitindo } \\
\text { mudanças }\end{array}$ & \begin{tabular}{|lr|}
\multicolumn{3}{|l|}{ teorias mudam ou podem } \\
mudar à medida que \\
novas & evidências, \\
interpretações $r$ & e \\
conhecimentos surgem, \\
assim a ciência de \\
desenvolve
\end{tabular} & $\begin{array}{l}0 \quad \text { homem } \\
\text { muda } \quad \text { e } \\
\text { assim novas } \\
\text { ideias } \\
\text { surgem }\end{array}$ \\
\hline $\begin{array}{l}\text { Compreender e } \\
\text { aperfeiçoar a ciência, } \\
\text { interpretando melhor } \\
\text { o que conhecemos }\end{array}$ & $1,4,11,17$ & $3,5,6,8,9,10,13,16,17$ & 2,12 \\
\hline $\begin{array}{l}\text { compreender os } \\
\text { processos } \\
\text { abordados por ela }\end{array}$ & 14,15 & 7 & \\
\hline $\begin{array}{l}\text { encontrar um } \\
\text { caminho para que ela } \\
\text { se torne uma lei }\end{array}$ & & & \\
\hline Não respondeu & & & \\
\hline
\end{tabular}

Tabela 22 - Categorias obtidas a partir das respostas dos alunos à pergunta número 7 do VNOS-C na primeira etapa de aplicação do questionário. 


\begin{tabular}{|c|c|c|c|}
\hline Mudam porque & $\begin{array}{l}\text { métodos de } \\
\text { investigação e } \\
\text { as tecnologias } \\
\text { mudam } \\
\text { permitindo } \\
\text { mudanças }\end{array}$ & $\begin{array}{l}\text { teorias mudam ou } \\
\text { podem mudar à medida } \\
\text { que novas evidências, } \\
\text { interpretações a } \\
\text { conhecimentos surgem, } \\
\text { assim a ciência de } \\
\text { desenvolve }\end{array}$ & $\begin{array}{l}\text { 0 homem } \\
\text { muda r e } \\
\text { assim novas } \\
\text { ideias } \\
\text { surgem }\end{array}$ \\
\hline $\begin{array}{l}\text { Compreender e } \\
\text { aperfeiçoar a ciência, } \\
\text { interpretando melhor } \\
\text { o que conhecemos }\end{array}$ & $4,3,13,15,17$ & 16 & $5,6,8,14,11$ \\
\hline $\begin{array}{l}\text { compreender os } \\
\text { processos } \\
\text { abordados por ela }\end{array}$ & & & 10 \\
\hline $\begin{array}{l}\text { encontrar um } \\
\text { caminho para que ela } \\
\text { se torne uma lei }\end{array}$ & 12 & & \\
\hline Não respondeu & 1 & & $2,7,9$ \\
\hline
\end{tabular}

Tabela 23 - Categorias obtidas a partir das respostas dos alunos à pergunta número 7 do VNOS-C na segunda etapa de aplicação do questionário.

Para a dimensão "mudam porque" foram produzidas três categorias. A diferença entre as categorias está na ênfase que os alunos deram aos motivos das mudanças. Em uma das categorias os alunos enfatizaram os métodos de investigação e a tecnologia. Como exemplo desta categoria há a resposta do aluno 15, na primeira etapa: "As teorias mudam com o tempo graças ao aperfeiçoamento de técnicas e experimentos". Em outra categoria os alunos enfatizaram $o$ surgimento de novas evidências, interpretações e conhecimentos. Um exemplo desta categoria é a resposta do aluno 6, na primeira etapa: "As teorias mudam a partir do momento em que novos conhecimentos são adquiridos, com isso, as teorias são aprimoradas". $\mathrm{Na}$ última das categorias obtidas para a dimensão "mudam porque" os alunos enfatizaram que o homem muda e assim novas ideias surgem. A resposta do aluno 2, na primeira etapa serve de exemplo para esta categoria: "As teorias mudam porque o homem muda e novas ideias surgem a cada minuto".

Podemos observar que na primeira etapa do questionário a maior parte dos alunos se encaixou na categoria que enfatiza novas evidências, interpretações e conhecimentos. Já a categoria que relaciona a mudança das teorias à uma mudança de pensamento humano foi a categoria menos relacionada. O inverso ocorreu na segunda etapa. 
Na dimensão "aprendemos para" a maioria dos alunos, nas duas etapas, tiveram suas respostas agrupadas na categoria "para compreender e aperfeiçoar a ciência, interpretando melhor o que conhecemos". Essa posição dos alunos está de acordo com os referenciais teóricos que seguimos, onde a ciência é provisória e está em constante desenvolvimento.

Não observamos respostas dadas ao questionário VNOS-C onde os alunos adotassem uma posição que as teorias não mudam.

No questionário VOSE, o aspecto da NdC o conhecimento científico é provisório, é introduzido com a seguinte afirmação na questão 4: "Mesmo que as investigações científicas sejam realizadas corretamente, a teoria proposta ainda pode ser contestada no futuro". Os resultados da análise das respostas podem ser observados na Tabela 24 , abaixo.

\begin{tabular}{|c|c|c|c|c|c|c|c|}
\hline \multirow{2}{*}{ QUESTÕES } & \multirow{2}{*}{ FASE } & \multicolumn{5}{|c|}{ FREQUÊNCIA DE ALUNOS } & \multirow{2}{*}{$\mathbf{R M}$} \\
\hline & & DT & DP & I & CP & CT & \\
\hline \multirow{2}{*}{$\begin{array}{l}\text { 4A. A investigação científica } \\
\text { enfrentará } \\
\text { revolucionária, e a teoria antiga } \\
\text { será substituída. }\end{array}$} & $1^{\circ}$ & 4 & 4 & 5 & 15 & 0 & 3,10 \\
\hline & $2^{\circ}$ & 1 & 2 & 6 & 15 & 4 & 3,67 \\
\hline \multirow{2}{*}{$\begin{array}{l}\text { 4B. Avanços científicos não } \\
\text { podem ser feitos em um curto } \\
\text { espaço de tempo. Acontecem por } \\
\text { meio de um processo cumulativo, } \\
\text { portanto, a velha teoria é } \\
\text { preservada. }\end{array}$} & $1^{\circ}$ & 7 & 11 & 0 & 8 & 2 & 2,53 \\
\hline & $2^{\circ}$ & 5 & 10 & 1 & 11 & 1 & 2,75 \\
\hline \multirow{2}{*}{$\begin{array}{l}\text { 4C. Com o acúmulo de dados de } \\
\text { pesquisa e de informação, a } \\
\text { teoria irá evoluir de forma mais } \\
\text { precisa e completa, não sendo } \\
\text { contestada. }\end{array}$} & $1^{\circ}$ & 3 & 10 & 3 & 10 & 2 & 2,92 \\
\hline & $2^{\circ}$ & 3 & 8 & 2 & 14 & 1 & 3,07 \\
\hline
\end{tabular}

Tabela 24 - Ranking médio das respostas de cada um dos itens da questão 4 do VOSE.

Observamos que nenhum dos itens disponíveis no questionário traz uma opção para os alunos discordarem do desenvolvimento do conhecimento científico. Os itens 4A e 4B buscam investigar a forma como ocorre 0 desenvolvimento do conhecimento científico. A partir do aumento do RM no 
item 4A, observamos, nas duas etapas, que os alunos concordam com a afirmação que as teorias mudam de forma revolucionária, quando teorias antigas são substituídas por teorias novas. Já para o item 4B, o qual apresenta um enunciado a favor de um desenvolvimento cumulativo, o RM menor do que 3 aponta que os alunos discordaram dessa afirmação.

Para o item 4C, que busca investigar se os alunos concordam que a teoria irá evoluir até não ser mais contestada, observamos uma mudança na concordância, quando comparadas as duas etapas. Na primeira etapa os alunos adotaram uma posição de discordância do item $4 \mathrm{C}$ e na segunda etapa eles passaram a concordar com a afirmação. Essa mudança não está de acordo com os referenciais teóricos sumarizados por nós, isto é, não está de acordo com a ideia de que teorias podem ser substituídas por outras, conforme a ciência se desenvolve.

Assim, essa mudança de opinião, não esperada, no item $4 \mathrm{C}$ do VOSE não corresponde às respostas ao mesmo item no questionário VNOS-C, no qual não houve respostas que afirmavam que a ciência é um conhecimento final. Segundo depoimento do professor Luis Netto, esse aspecto da NdC foi trabalhado em sala de aula, mas as respostas dos questionários apresentam inconsistência. Esta inconsistência só poderia ser elucidada mediante entrevista com os alunos, procurando determinar se a inconsistência se deve a interpretação do enunciado ou a algum outro aspecto. Contudo, a delimitação da pesquisa para os prazos do mestrado levou a não incluir essa outra fonte de dados. 


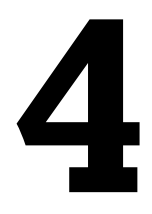

CONCLUSÕES 
Consideramos que as ferramentas analisadas permitiram coletar dados significativos sobre as concepções dos estudantes acerca da $\mathrm{NdC}$ e que permitiram observar mudanças, pelo menos para alguns dos aspectos investigados, durante o semestre letivo. Tais mudanças nos parecem no mínimo interessantes especialmente pelo fato de os questionários não terem sido objeto de discussão nas disciplinas do curso, de modo a excluir tendências nas respostas dos alunos induzidas pelos professores. Esse não conhecimento sobre os temas dos questionários à luz dos resultados obtidos aumenta a evidência de que o tratamento sobre as ciências nas suas disciplinas surtiu algum efeito entre os alunos (considerando-se, claro, que é possível também que as concepções dos alunos também sofreram alterações decorrentes de outras fontes, externas às disciplinas cursadas no IB-USP, como cursos em outros lugares, leituras espontâneas etc.).

Os alunos atribuíram participação da criatividade e imaginação no processo de construção do conhecimento científico no início e no final do semestre, embora tenham alterado as justificativas e a identificação das etapas da pesquisa científica nas quais há a participação da criatividade e imaginação. No final do curso, aumentou o número de alunos que passou a creditar a influência de valores socioculturais na ciência, bem como a considerar que a ciência é uma construção humana.

Com relação à ciência ser determinada por teorias e refletir crenças pessoais, não foi possível percebermos mudanças observáveis, quando investigamos as respostas dos grupos de alunos. Vimos que, tanto no início quanto no final do semestre letivo, os alunos que responderam o VNOS-C tiveram uma opinião de que as crenças pessoais influenciam o trabalho do cientista. Já os alunos que responderam o VOSE, passaram a adotar uma opinião contrária à influência de valores pessoais na ciência, quando responderam aos itens da questão 8 e, aceitaram que as influências pessoais interferem na construção do conhecimento científico quando responderam aos itens da questão 15.

Outro aspecto da NdC no qual não percebemos diferenças entre as etapas, no sentido dos alunos apresentarem uma visão epistêmica mais elaborada e de acordo com os referenciais teóricos sumarizados por nós no capítulo 1 e na seção 2.3.4, foi o aspecto da ciência o qual afirma que o 
conhecimento científico é provisório. Houve até mesmo uma inconsistência nas respostas, pois a maioria dos alunos que respondeu ao VNOS-C não atribuiu, em nenhuma das etapas, que a ciência é uma forma de conhecimento pronto, os alunos que responderam o VOSE concordaram com a afirmação de que a ciência chegará a um ponto em que não será mais contestada.

Também não foram observadas diferenças durante o semestre com relação à concepção dos alunos sobre leis e teorias científicas serem formas diferentes de conhecimento, o que está em sintonia com os referenciais teóricos que adotamos. No entanto, de forma geral, nas duas etapas os alunos atribuíram certa hierarquia entre leis e teorias científicas, em que as leis seriam formas de conhecimento melhores. Com destaque para esse aspecto da $\mathrm{NdC}$, sobre o qual há muita discussão no âmbito da própria filosofia da ciência, é importante que professores de ciências tenham cuidado em fornecer definições precisas e completas sobre os conceitos de lei e teoria. No caso específico de professores de biologia há ainda a preocupação de que os alunos percebam as peculiaridades encontradas para estes conceitos nas ciências biológicas.

Quando analisamos de forma geral todos os aspectos investigados, consideramos que as ferramentas analisadas permitiram coletar dados significativos sobre as concepções dos estudantes sobre a Natureza da Ciência e que permitiram observar algumas mudanças ao longo do semestre letivo. As mudanças apresentadas nos pareceram no mínimo interessantes, especialmente pelo fato de os aspectos investigados, vale novamente ressaltar, não terem sido objeto de discussão nas disciplinas do curso, de modo a excluir tendências nas respostas dos alunos induzidas pelos professores.

Com relação ao questionário VNOS-C é possível realizar comparações dos nossos resultados com os resultados de duas pesquisas, também desenvolvidas no Brasil e para alunos de graduação. Uma delas é apresentada no artigo do Elder Teixeira, Olival Freire Jr. E Charbel El-Hani (2009) e a outra apresentada no artigo do Charbel El-Hani, Eraldo Tavares e Pedro Rocha (2004). Em semelhança com os dados encontrados por nós, esses pesquisadores concluíram que houve, de um modo geral, um amadurecimento no concepção dos estudantes que participaram da pesquisa, quando comparadas a primeira e segunda fases. Porém há uma diferença fundamental entre esses estudos e o presente trabalho, pois neles foram realizados, entre o 
pré e pós-testes, cursos enfocando explicitamente conteúdos epistemológicos, tendo em conta as dimensões histórica e filosófica da atividade científica.

Com relação ao VOSE, não foram encontradas pesquisas desenvolvidas no Brasil que tivessem utilizado o questionário para que pudéssemos realizar qualquer tipo de comparação.

Como era de se esperar, as questões abertas do VNOS-C possibilitaram que os alunos expressassem livremente suas concepções. Com relação às questões fechadas do VOSE, elas permitiram a aplicação de um número maior de questões, facilitaram o processo de tabulação e possibilitaram aos alunos refletir sobre características da ciência que poderiam ser desconhecidas, até então, para eles. Porém, como era previsto, as questões fechadas do VOSE limitaram a análise das concepções dos alunos.

Para os dois questionários é possível também que a ordem das posições sobre a NdC apresentadas nas questões possa ter influenciado as respostas dos alunos. Na maioria das questões dos dois questionários, os itens que apresentam a concepção sobre a NdC atualmente aceita aparecem primeiro. De qualquer forma, serão sempre necessárias revisões e modificações, como por exemplo, a realizada por Angélica Porra, Nilva Sales e Cibelle Silva (2011) para o VNOS-C.

O referencial metodológico de Laurence Bardin utilizado para analisar os resultados do VNOS-C, a partir da criação de dimensões, que por sua vez permitiram criar categorias a partir de perspectivas diferentes, trouxe um maior detalhamento na investigação das respostas, o que proporcionou uma análise mais criteriosa. No caso do VOSE, o cálculo do Ranking Médio, auxiliou na percepção da opinião do grupo de alunos e se mostrou ser um método prático e informativo que pode ser facilmente utilizado por outros. Essa simplicidade, ligada, claro, à eficiência, foi o critério para a escolha desse método e se mostrou produtivo após a utilização.

O Questionário Sociocultural e de Opinião Sobre a Importância da NdC possibilitou termos uma visão do perfil e observarmos o interesse dos alunos quanto às questões investigadas. Muitos alunos declararam não ter lembrado das questões ao longo do semestre, mas a maioria considerou importante o conhecimento sobre as questões investigadas. Seria interessante uma investigação semelhante no início das disciplinas, a fim de tentar detectar quais 
aspectos da ciência os alunos se interessam, podendo assim fornecer subsídios para o desenvolvimento de estratégias e conteúdos que as contemplem no ensino.

A partir das entrevistas, observamos a preocupação dos professores em trabalhar questões sobre a NdC e assim contextualizar o ensino, seja de forma implícita ou explícita. Isso mostra que de alguma maneira os professores são sensíveis a questões discutidas no âmbito das pesquisas sobre ensino de ciências, história das ciências e filosofia das ciências.

A triangulação utilizada foi importante para atingirmos os objetivos propostos, auxiliando na ampliação da coleta e da análise dos dados.

As diferenças de opinião sobre quais aspectos da $\mathrm{NdC}$ devem ser abordados no ensino de ciências, como os sete itens de Lederman (2007) e as discussões apresentadas no capítulo 1, são justificadas, a nosso ver, mediante os diferentes interesses de pesquisa e/ou práticas de ensino. Esta pesquisa trouxe algumas evidências que corroboram a ideia de que tais itens são úteis para investigar como ocorre o ensino de questões metacientíficas, conforme encontrado nas percepções dos alunos que cursaram o primeiro semestre letivo do curso de Ciências Biológicas do IB-USP.

A nossa verificação do tempo necessário à aplicação dos questionários permitiu observar que é possível utilizar qualquer um dos questionários no tempo previsto de 50 minutos. Desse modo, qualquer um dos dois questionários pode ser aplicado tanto em aula do Ensino Superior, como também em aulas do Ensino Médio, que em geral possuem esse tempo de duração nas escolas brasileiras.

Não tivemos a pretensão de que os questionários e, acreditamos, nenhuma outra ferramenta de coleta de dados utilizada de forma isolada, fosse capaz de coletar exaustivamente o que os alunos compreendem por ciência e tudo que a envolve. Limitações das ferramentas e ou da análise dos resultados obtidos por determinado instrumento não impedem, contudo, que eles sejam utilizados. Acreditamos que esses questionários foram úteis, e podem servir em futuras pesquisas, como guias para estudos que tenham como objetivo o conhecimento de concepções de determinado público alvo sobre a $\mathrm{NdC}$. Os instrumentos também podem ser adequados aos objetivos e delimitações de cada pesquisa. 
Perante as dificuldades discutidas na literatura sobre a introdução de questões metacientíficas no ensino, acreditamos que a introdução de questões sobre a ciência no ensino auxiliariam alcançar os objetivos do Projeto Pedagógico do curso de Ciências Biológicas do IB/USP.

A aplicação de questionários, como os aqui utilizados, para a realização de sondagens de concepções prévias pode auxiliar o professor a adotar estratégias de ensino que sejam capazes de promover um ensino direcionado às questões sobre ciência. Aplicados ao final de uma intervenção didática, podem fornecer dados de modo a balizar trabalhos futuros. Discussões sobre os conceitos que os alunos possuem sobre a NdC são importantes para elaboração e aplicação de métodos de ensino, como por exemplo, na utilização de abordagem baseadas em problemas, transposições didáticas, utilização de experimentos históricos, entre outros métodos. 


\section{Referências Bibliográficas}

ABD-EL-KHALICK, Fouad; LEDERMAN, Norman G. Improving science Teachers' conceptions of nature of science: a critical review of the literature. International Journal of Science Education, v. 22, n. 7, p. 665-701, 2000.

ACEVEDO, José Antonio; VÁZQUEZ, A.; PAIXÃO, M. F.; ACEVEDO, P.; OLIVA, J. M.; MANASSERO, M. A. Mitos da didática das ciências acerca dos motivos para incluir a Natureza da Ciência no Ensino das Ciências. Ciência \& Educação, Bauru, v. 11, n. 1, p. 1-15, 2005.

AIKENHEAD, Glen S.; RYAN, Alan G. The development of a New Instrument: "Views on science-technology-Society" (VOSTS). Science Education, v. 76, n. 5, p. 477-491, 1992.

ALLCHIN, Douglas. Evaluating knowledge of the Nature of (Whole) Science. In: Anais da 8th International Conference for the History of Science in Science Education. Maresias, 2010.

ALTERS, Brian J. Whose Nature of Science? Journal of Research in Science Teaching, v. 34, n. 1, p. 39-55, 1997.

ANDRADE, Clarissa Souza de. Concepções de alunos do Curso de Pedagogia da UFRN acerca da natureza da ciência: subsídios à formação de professores. Natal, 2008. Dissertação (Mestrado em Educação) - Universidade Federal do Rio Grande do Norte.

BARDIN, Laurence. Análise de conteúdo. Trad. Luís Antero Reto e Augusto Pinheiro. Lisboa: Edições 70, 2011.

BIZZO, Nelio; EL-HANI, Charbel N. O arranjo curricular do ensino de evolução e as relações entre os trabalhos de Charles Darwin e Gregor Mendel. Filosofia e História da Biologia, v. 4, p. 235-257, 2004.

BOGDAN, Robert; BIKLEN, Sari. Investigação qualitativa em educação: uma introdução à teoria e aos métodos. Porto: Editora Porto, 2006.

BRASIL. CONSELHO NACIONAL DE SAÚDE. Diretrizes e normas regulamentadoras de pesquisas envolvendo seres humanos. Resolução $\mathrm{n}^{\circ}$ 196, de 10 de outubro de 1996. Brasília: CNS, 1996.

CANAVARRO, José M. Ciência e sociedade. Coimbra: Quarteto, 1999.

CHALMERS, Alan F. O que é ciência afinal? Trad. Raul Fiker. $7^{\circ}$ reimp. São Paulo: Brasiliense, 2009

EICK, Charles J. Inquiry, Nature of Science, and evolution: the need for a more complex pedagogical content knowledge in science teaching. Eletronic Journal 
of Science Education, v. 4, n. 3, 2000. Disponível em: <http://wolfweb.unr.edu/homepage/crowther/ejse/eick.html>. Acesso em: 25 jan. 2010.

CHEN, Sufen. Development of an instrument to assess views on Nature of Science and attitudes toward teaching science. Science Education, v. 90, n. 5, p. 803-819, 2006.

COLLINS, Sue; OSBORNE, Jonathan; RATCLIFFE, Mary; MILLAR, Robin; DUSCHL, Rick. What 'ideas-about-science' should be taught in school science? A Delphi study of the expert community. Annual Conference of the American Educational Research Association. Seattle, 2001.

COOLEY, William W.; KLOPFER, Leopold E. Test on understanding science. Princeton, NJ: Educational Testing Service, 1961.

COSTA, Cláudio F. Falseacionismo e anti-indutivismo popperianos. Theoria Revista Eletrônica de Filosofia, Pouso Alegre, v. 4, n. 9, p. 17-24, 2012.

DENZIN, Norman K. Triangulation in educational research. Pp. 511-513, in: KEEVES, J. P. (ed). Educational research, methodology, and measurement: an international handbook. Oxford: Pergamon Press, 1988.

DOURADO, Luís; SEQUEIRA, Manuel. Uma análise da relação entre os conceitos de método científico e de investigação. Pp. 1-9, in: $X X$ Encuentros de Didáctica de las Ciencias Experimentales. Atas electrónicas, 2002. Acesso em 10/09/2012, <http://apice.webs.ull.es/pdf/351-076.pdf>

DRIVER, Rosalind; LEACH, John; MILLAR, Robin; SCOTT, Philip. Young peoples's images of science. Lancaster: Open University Press, 1996.

DRIVER, Rosalind; ASOKO, H.; LEACH, John; MORTIMER, Eduardo; SCOTT, Philip. Construindo conhecimento científico na sala de aula. Química Nova na Escola, n. 9, p. 31-40, 1999.

EL-HANI, Charbel N.; TAVARES, Eraldo J. M.; ROCHA, Pedro L. B. Concepções epistemológicas de estudantes de biologia e sua transformação por uma proposta explícita de ensino sobre História e Filosofia das Ciências. Investigações em Ensino de Ciências, v. 9, n. 3, p. 265-313, 2004.

FERREIRA, Juliana M. H. Contribuições da história das (pseudo) ciências para a abordagem da Natureza da Ciência: um estudo de caso. VII Encontro Nacional de Pesquisas em Educação em Ciências. Florianópolis, 2009.

FEYERABEND, Paul. Contra o método. Trad. de Octanny S. da Mota e Leônidas Hegenberg. Rio de Janeiro: Francisco Alves, 1977.

FORATO, Thaís C. de M. A natureza da ciência como saber escolar: um estudo de caso a partir da história da luz. Tese (Doutorado em Educação) - Faculdade de Educação, Universidade de São Paulo. São Paulo, 2009. 
GIL, Antônio Carlos. Métodos e técnicas de pesquisa social. São Paulo: Editora Atlas, 1999.

GIL-PÉREZ, Daniel; MONTORO, Isabel F.; ALÍS, Jaime C.; CACHAPUZ, António; PRAIA, João. Para uma imagem não deformada do trabalho científico. Ciência \& Educação, v. 7, n. 2, p. 125-153, 2001.

GIORDAN, A. Une didactique pour les sciences expérimentales: Paris: Belin, 1999.

GORING, Paul A. Manual de medições e avaliação do rendimento escolar. Coimbra: Livraria Almedina, 1981.

GROTZER, Tina A.; MILLER, Rebecca B.; LINCOLN, Rebecca A. Perceptual, Attentional, and Cognitive Heuristics That Interact with the Nature of Science to Complicate Public Understanding of Science. In: KHINE, Myint S. (ed.). Advances in Nature of Science research: concepts and methodologies. Dordrecht: Springer, 2012.

HARRES, João B. S. Uma revisão de pesquisas nas concepções de professores sobre a natureza da ciência e suas implicações para o ensino. Investigações em Ensino de Ciências, v. 4, n. 3, p. 197-211, 1999.

HODSON, D. Filosofia de la ciencia y educacion cientifica. Pp. 5-21, in: PORLÁN, R.; GARCÍA, J. E.; CAÑAL, P. (Orgs.). Constructivismo y enseñanza de las ciencias. Sevilha: Díada, 1988.

HORNER, J.K.; RUBBA, P. A. The laws are mature theories fable. The Science Teacher, v. 46, n. 2, p. 31,1979.

IB-USP. Genética: BIO-203 (Apostila). São Paulo: Instituto de Biociências da Universidade de São Paulo, 2009.

IB-USP. Projeto Pedagógico: Ciências Biológicas. São Paulo: Instituto de Biociências da Universidade de São Paulo, 2007.

IRZIK, Gürol; NOLA, Robert. A family resemblance approach to the Nature of Science for science education. Science \& Education, v. 20, p. 591-607, 2011.

KIMBALL, Mekritt E. Understanding the nature of science: Acomparison of scientists and science teachers. Journal of Research in Science Teaching, v. 5, p. $110-120,1967-68$.

KUHN, Thomas S. A estrutura das revoluções científicas. Trad. Beatriz Vianna Boeira e Nelson Boeira. São Paulo: Perspectiva, 2009.

LAKATOS, Imre. History of science and its rational reconstructions. Proceedings of the Biennial Meeting of the Philosophy of Science Association, 1970. 
LEDERMAN, Norman. G. Student's and teacher's conceptions of the nature of science: a review of the research. Journal of Research in Science Teaching, v. 29, n. 4, p. 331-359, 1992.

Nature of Science: Past, Present, and Future. Pp. 831-880, in: ABELL, Sandra K.; LEDERMAN, Norman G. (Ed.). Handbook of research on science education. New Jersey: Lawrence Erlbaum Associates, 2007.

LEDERMAN, Norman G.; ABD-EL-KHALICK, Fouad; BELL, Randy; SCHWARTZ, Reneé S. Views of Nature of Science questionnaire: toward valid and meaningful assessment of learners' conceptions of Nature of Science. Journal of Research in Science Teaching, v. 39, n. 6, p. 497-521, 2002.

LEDERMAN, Norman G.; O'MALLEY, Molly. Students' perceptions of tentativeness in science: development, use, and sources of change. Science Education, v. 74, n. 2, p. 225-239, 1990.

LIANG, Ling L.; CHEN, Sufen; CHEN, Xian; KAYA, Osman N.; ADAMS, April D.; MACKLIN, Monica; EBENEZER, Jazlin. Student understanding of science and scientific inquiry (SUSSI): revision and further validation of an assessment instrument. Annual Conference of the National Association for Research in Science Teaching. San Francisco, 2006.

LIN Chen-Yung. The Development and Validation of the Understanding of the Nature of Science Scale. Chinese Journal of Science Education, v. 4, n. 1, 1996.

LORENZANO, Pablo. Filosofía de la ciencia. Buenos Aires: Universidad Nacional de Quilmes, 2004.

LUCKESI, Cipriano C. Avaliação da Aprendizagem: componente do ato pedagógico. São Paulo: Cortez, 2011.

MAFFEZZOLLI, Eliane C. F.; BOEHS, Carlos G. E. Uma reflexão sobre o estudo de caso como método de pesquisa. Revista da FAE, v.11, n.1, p. 95110, 2008.

MALHOTRA, Naresh. Pesquisa de marketing: uma orientação aplicada. Porto Alegre: Bookman, 2006.

MANASSERO, M. A.; VÁZQUEZ, A.; ACEVEDO, J. A. Cuestionario de Opiniones sobre Ciencia, Tecnología y Sociedad (COCTS). Princeton, Educational Testing Service, 2003.

MARTINS, Lilian Al-Chueyr P. A História da Ciência e o ensino de Biologia. Ciência \& Ensino, v. 5, p. 18-21, 1998. 
MARTINS, Roberto de A.; PRESTES, Maria Elice B.; SILVA, Cibelle C. History and philosophy of science in science education, in Brazil. In: MATTHEWS, Michael R. (ed.) History, Philosophy and Science Teaching Handbook. Dordrecht: Springer, no prelo.

MATTHEWS, Michael R. Science teaching: the role of history and philosophy of science. New York: Routledge, 1994.

Changing the focus: from Nature of Science (NOS) to Features of Science (FOS). In: KHINE, Myint S. (ed.). Advances in Nature of Science research: concepts and methodologies. Dordrecht: Springer, 2012.

MAYR, Ernst. Isto é biologia: a ciência do mundo vivo. Trad. Cláudio Angelo. São Paulo: Companhia das Letras, 2008.

McCOMAS, W. F. A textbook case of the Nature of Science: laws and theories in the science of Biology. International Journal of Science and Mathematics Education, v. 1, n. 2, p. 141-155, 2003.

McCOMAS, William F., CLOUGH, M., \& ALMAZORA, H. The Nature of Science in Science Education: an introduction. Science \& Education, v. 7, n. 6, p. 511532, 1998.

MCMULLIN, E. Scientific controversy and its termination. In: ENGELHARDT Jr.; TRISTAM H.; CAPLAN, A. L. Scientific Controversy: Case studies in the resolution and closure of disputes in Science and technology. Cambridge: Cambridge University Press, 1987.

MEDEIROS, A.; BEZERRA FILHO, S. A natureza da ciência e a instrumentação para o ensino de física. Ciência \& Educação, v. 6, n. 2, p. 107$117,2000$.

OKI, Maria da Conceição M. O ensino de História da Química:contribuindo para a compreensão da Natureza da Ciência. Ciência \& Educação, v.14, n. 1, p. 6788, 2008.

OLIVEIRA, Luciel Henrique de. Exemplo de cálculo de Ranking Médio para Likert. Apostila de curso de Metodologia Científica e Técnicas de Pesquisa em Administração. Mestrado em Administração e Desenvolvimento Organizacional. Faculdade Cenecista de Varginha. Varginha, 2005.

PARASKEVOPOULOU, Eleni; KOLIOPOULOS, Dimitris. Teaching the Nature of Science through the Millikan-Ehrenhaft dispute. Science \& Education, v. 20, n. 10, p. 943-960, 2011.

PESSOA JR., Osvaldo. Filosofia \& Sociologia da Ciência. Aula ministrada na disciplina de HG-022, Epistemologia das Ciências Sociais, do curso de Ciências Sociais da Unicamp, a convite da Professora Doutora Fátima Évora. Campinas, 1993. Disponível em: <http://www.fflch.usp.br/df/opessoa/Soc1.pdf> 
POPPER, Karl. The logic of scientific discovery. London e New York: Routledge, 2005.

PORRA, Angélica C.; SALES, Nilva L. L.; SILVA, Cibelle C. Concepções de natureza da ciência: adaptação de um instrumento para aplicação em alunos de licenciatura de universidades públicas brasileiras. V Encontro Regional Sul de Ensino de Biologia e IV Simpósio Latino Americano e Caribenho de Educação em Ciências do International Council of Associations for Science Education. Campinas, 2011.

PRAIA J. F. O trabalho laboratorial no ensino das ciências: contributos para uma reflexão de referência epistemológica. Pp. 55-75, in: Portugal. Conselho Nacional de Educação, Ministério da Educação. Ensino experimental e construção de saberes. Lisboa: Ministério da Educação, 1999.

PRESTES, Maria Elice B.; CALDEIRA, Ana. Maria. A. Introdução: a importância da história da ciência na educação científica. Filosofia e História da Biologia, v. 4, p. 1-16, 2009.

REID, David V.; HODSON, Derek. Ciência para todos en secundaria. Madrid: Narcea, 1993.

REIS, Pedro G. R. Controvérsias sócio-científicas: discutir ou não discutir? Percursos de aprendizagem na disciplina de Ciências da Terra e da Vida. Lisboa, 2004. Tese. (Doutorado em Educação) - Departamento de Educação, Faculdade de Ciências, Universidade de Lisboa.

RUBBA, Peter A. The development, field testing and validation of an instrument to assess secondary school students' understanding of the nature of scientific knowledge. Dissertations Abstracts International, 1977.

SANTOS, Maria Eduarda N. V. M. Educação pela ciência e educação sobre ciência nos manuais escolares. II Encontro Iberoamericano sobre Investigação Básica em Educação em Ciências. Burgos, 2004.

SCHEID, Neusa M. J.; FERRARI, Nadir; DELIVOICOV, Demétrio. Concepções sobre a Natureza da Ciência num curso de Ciências Biológicas: imagens que dificultam a educação científica. Investigações em Ensino de Ciências v. 12, n. 2, p. 151-181, 2007.

SILVA, Cibelle C.; MARTINS, Roberto de A. A teoria das cores de Newton: um exemplo do uso da História da Ciência em sala de aula. Ciência \& Educação, v. 9, n. 1, p. 53-65, 2003.

SILVA, Cibelle C.; PRESTES, Maria Elice B. (Guest Editors). Special Issue: First IHPST Latin American Regional Conference: Select Contributions. Science \& Education, v. 21, n. 5, p. 603-766, 2012. 
SHINN, Terry; RAGOUET, Pascal. Controvérsias sobre a ciência: por uma sociologia transversalista da atividade científica. Trad. Pablo Rubén Mariconda e Sylvia Gemignani Garcia. São Paulo: Editora 34, 2008.

STURMAN, A. Case study methods. Pp. ?-?, in: KEEVES, J. P. (ed). Educational research, methodology, and measurement: an international handbook. Oxford: Pergamon Press,1988.

TAVARES, Eraldo J. M. Evolução das Concepções de Alunos de Ciências Biológicas da UFBA Sobre a Natureza da Ciência: Influências da Iniciação Científica, das Disciplinas de Conteúdo Específico e de Uma Disciplina de História e Filosofia das Ciências. Dissertação (Mestrado em Ensino, Filosofia e História das Ciências). Universidade Federal da Bahia e Universidade Estadual de Feira de Santana. Salvador, 2006.

TEIXEIRA, Elder Sales; FREIRE JR, Olival; EL-HANI, Charbel Niño. A influência de uma abordagem contextual sobre as concepções acerca da natureza da ciência de estudantes de física. Ciência \& Educação, v. 15, n. 3, p. 529-556, 2009.

WELCH, Wayne W. Science process inventory. Cambridge, MA: Harvard University Press, 1967.

WILSON, Leland. A study of opinions related to the nature of science and its purpose in society. Science Education, v. 38, n. 2, p. 159-164, 1954.

YIN, Robert K. Estudos de caso: planejamento e métodos. Porto Alegre: Bookman, 2005.

ZATERKA, Luciana. Filosofia experimental na Inglaterra do século XVII: Francis Bacon e Robert Boyle. São Paulo: Humanitas, 2004. 
Anexos 


\section{ANEXO 1: Termo de Consentimento Livre e Esclarecido}

\section{Termo de Consentimento Livre e Esclarecido}

Concordo em participar, como voluntário(a), de uma pesquisa que será realizada pelo biólogo João Paulo Di Monaco Durbano RG 44216921-8, mestrando do programa de pós-graduação em Ciências Biológicas (Biologia Genética) da Universidade de São Paulo.

Esta pesquisa tem a finalidade de investigar a percepção que os estudantes de graduação do curso de Ciências Biológicas da Universidade de São Paulo têm sobre a Natureza da Ciência.

Para isso, será feita uma pesquisa com o uso de questionários padronizados onde os participantes irão responder às questões de acordo com seus conhecimentos. A duração aproximada desta sessão será de 40 minutos, tomando o cuidado de agendar um horário que não prejudique as atividades acadêmicas do aluno.

Esta atividade não é obrigatória e, caso não queira participar, isso em nada afetará o tratamento que você recebe nesta instituição.

Ao decidir aceitar participar deste estudo, tomei conhecimento de que:

- Caso não me sinta à vontade com alguma questão da sessão, estou ciente de que posso deixar de respondê-la, sem que isso implique em qualquer prejuízo.

- Estou livre para desistir da participação em qualquer momento desta pesquisa.

- Sei que as informações que eu fornecerei poderão, mais tarde, serem utilizadas para trabalhos científicos e, que fui informado que a minha identificação será mantida sob sigilo.

- Não há nenhum risco significativo para mim em participar deste estudo.

- A minha participação neste estudo é inteiramente voluntária, não tendo sofrido nenhuma forma de pressão para isso.

- Não haverão despesas por minha parte.

$\mathrm{Eu}$, Considerando as observações acima:

a minha participação neste trabalho poderá abrir um espaço para que eu expresse minhas opiniões e percepções sobre o assunto pesquisado, que poderão ser úteis para um maior conhecimento sobre o tema e para a expansão de estudos nesta área.

E caso tiver que contatar o pesquisador João Paulo Di Monaco Durbano e/ou sua orientadora Profa. Dra. Maria Elice Brzezinski Prestes, para qualquer tipo de explicação, sei o endereço que devo recorrer, sendo este: Rua do Matão, 277, sala $317 \mathrm{~A}$

Cidade Universitária, CEP: 05508-090 - São Paulo, SP - Brasil, e-mails: joaodurbano@gmail.com e eprestes@ib.usp.br.

Eu recebi uma cópia deste termo e a possibilidade de lê-lo.

São Paulo, de de 2010.

Assinatura do voluntário

Assinatura do Pesquisador

Responsável 


\section{ANEXO 2: CONTEÚDOS DESCRITOS NAS EMENTAS DAS DISCIPLINAS}

\section{- Genética:}

Teórico: Hereditariedade pré-mendeliana e a natureza da ciência. O trabalho de Mendel. Probabilidade e teste de hipótese genética (X2). Herança quantitativa. Interação gênica e pleiotropia. Teoria cromossômica da herança. Herança ligada ao sexo. Compensação de dose. Alelos múltiplos. Ligação gênica, permutação, recombinação e mapeamento cromossômico. Determinação do sexo. Mutações. Genes letais. Teoria um gene - uma enzima. Prático: Experimento com Drosophila melanogaster envolvendo a determinação dos padrões de herança de quatro mutações e mapeamento cromossômico. Elaboração de um manuscrito simulado sobre o experimento realizado. Meiose: simulação com massa de modelar, recombinação e não-disjunção. Análise de metáfases mitóticas e cariótipos.

\section{- Filosofia das Ciências Biológicas}

1 - Introdução a Filosofia das Ciências; 2 - Limites e pressupostos da investigação, do conhecimento e da compreensão científica nas Ciências Biológicas; 3 - O papel das entidades teóricas nas Ciências Biológicas; 4 - O conceito de ser vivo; 5 - Evolução cultural.

\section{- Antropologia: Biologia e Cultura}

1. A gênese do pensamento antropológico: evolucionismo, colonialismo e a hegemonia do pensamento positivista. 2. A construção do conceito de cultura (Marx, Durkheim e Weber) 3. A construção do conceito de cultura (Funcionalismo e Historicismo). 4. O método etnográfico: a construção do outro primitivo. 5. Estrutura social e parentesco. 6. O conceito de adaptação na Antropologia. 7. Evolução social e materialismo. 8. Simbolismo e a construção do significado: o estruturalismo. 9. Simbolismo e a construção do significado: a hermenêutica. 10. O fim da grande narrativa nas ciências sociais. 11. Da sociobiologia à psicologia evolucionista: ainda há espaço para grandes narrativas? 12. Teoria social e abordagens alternativas: fenomenologia e teoria da prática. 13. A seleção natural e a mente humana: o adaptativo e o arbitrário. 


\section{- Fauna, Flora e Ambiente}

Conteúdo: 1. Atividades dos biólogos. 2. Detecção dos principais fatores do ambiente físico e antropogênicos; elementos do clima; solo; poluentes; alterações. Algumas técnicas básicas para análise desses fatores. 3 . Reconhecimento de indivíduos, populações e comunidades. Noções de espécies, ecossistemas, biomas e biosfera. 4. Reconhecimento de interações biológicas. 5. Obtenção de dados em estudos da fauna, flora e vegetação. Subsídios para o reconhecimento dos grandes grupos de organismos; adaptações ao meio; formas de vida; ciclos de vida. 6. Fundamentos metodológicos de coleta, preservação e caracterização. 7. Observação das variações na biodiversidade, em diferentes habitats. 


\section{Anexo 3: Questionário Sociocultural e de Opinião Sobre a Importância da NdC}

Nome:

1. Sexo: M ( ) F ( ) 2. Idade:

3. Você já fez ou está fazendo outro curso superior?

Não ( )

Sim ( ) Concluído: Sim ( ) Não ( )

Qual?

Onde?

4. Onde você cursou a maior parte do Ensino Fundamental?

( ) Escola Particular ( ) Escola Pública

5. Onde você cursou a maior parte do Ensino Médio?

( ) Escola Particular ( ) Escola Pública

6. Qual a sua participação na renda familiar?

( ) Não trabalha e recebe ajuda financeira da família.

( ) Trabalha e recebe ajuda financeira da família.

( ) Trabalha e não recebe ajuda financeira da família.

( ) Trabalha e contribui parcialmente para o sustento da família.

( ) Trabalha e é responsável pelo sustento da família.

7. Ao longo do semestre, você lembrou e/ou refletiu sobre alguma das questões do questionário respondido no início do curso? Quais?

$\operatorname{Sim}($ ) Não ( )

8. Você considera importante um biólogo conhecer as questões abordadas? Explique. 


\section{Anexo 4: Transcrição das entrevistas com os professores}

Transcrição da entrevista com a professora Dra. Mariana Cabral de Oliveira

\begin{tabular}{|l|l|l|}
\hline Turno & Tempo & \multicolumn{1}{|c|}{ Fala } \\
\hline A1 & $00: 00$ & Eu: Posso começar? \\
\hline A2 & $00: 01$ & Mariana: Pode! \\
\hline A3 & $00: 10$ & $\begin{array}{l}\text { Eu: Está sendo gravado, a senhora disse que não } \\
\text { tem problema nenhum. Então a gente vai focar } \\
\text { referente aos alunos e disciplina que a senhora deu. } \\
\text { Diversidade... }\end{array}$ \\
\hline A5 & $00: 29$ & $\begin{array}{l}\text { Mariana: No ano passado fui eu, a professora Sônia } \\
\text { Lopes. }\end{array}$ \\
\hline A6:36 & $\begin{array}{l}\text { Eu: Isso! Eu peguei o nome de todo mundo lá na } \\
\text { secretaria. Porque, às vezes muda. Às vezes têm o } \\
\text { nome de todo mundo, mas os quatro deram aula. } \\
\text { Primeira pergunta, eu queria que a senhora discutisse } \\
\text { sobre o chamado ensino contextual de ciências. Entre } \\
\text { outros pesquisadores da área, o educador Norman } \\
\text { Lederman, que é uma das minhas referências, propõe } \\
\text { que o ensino contextual seja feito por meio de } \\
\text { abordagens, durante as aulas, de questões } \\
\text { metacientíficas, tais como essas que eu vou te } \\
\text { mostrar agora... Ele propõe, e outros pesquisadores, } \\
\text { mas ele fez essa relação e que o ensino contextual } \\
\text { deve, durante as aulas, abordar questões como: a } \\
\text { diferença entre observação e inferência, a distinção } \\
\text { entre leis e teorias, a imaginação e criatividade } \\
\text { fazendo parte da ciência, o conhecimento científico é } \\
\text { determinado por teorias, a ciência sofre influência } \\
\text { cultural, nunca é absoluto ou certo, o conhecimento } \\
\text { científico e a distinção entre Natureza da Ciência e a } \\
\text { investigação científica. } \\
\text { Ai eu pergunto para a senhora se esses aspectos } \\
\text { devam ser trabalhados em sala de aula? }\end{array}$ \\
\hline $\begin{array}{l}\text { Mariana: Eu concordo e a gente trabalha. A maioria } \\
\text { destes aspectos a gente trabalha no curso. A prof. } \\
\text { Sônia dá uma aula que vai... como a gente passa por }\end{array}$ \\
\hline
\end{tabular}




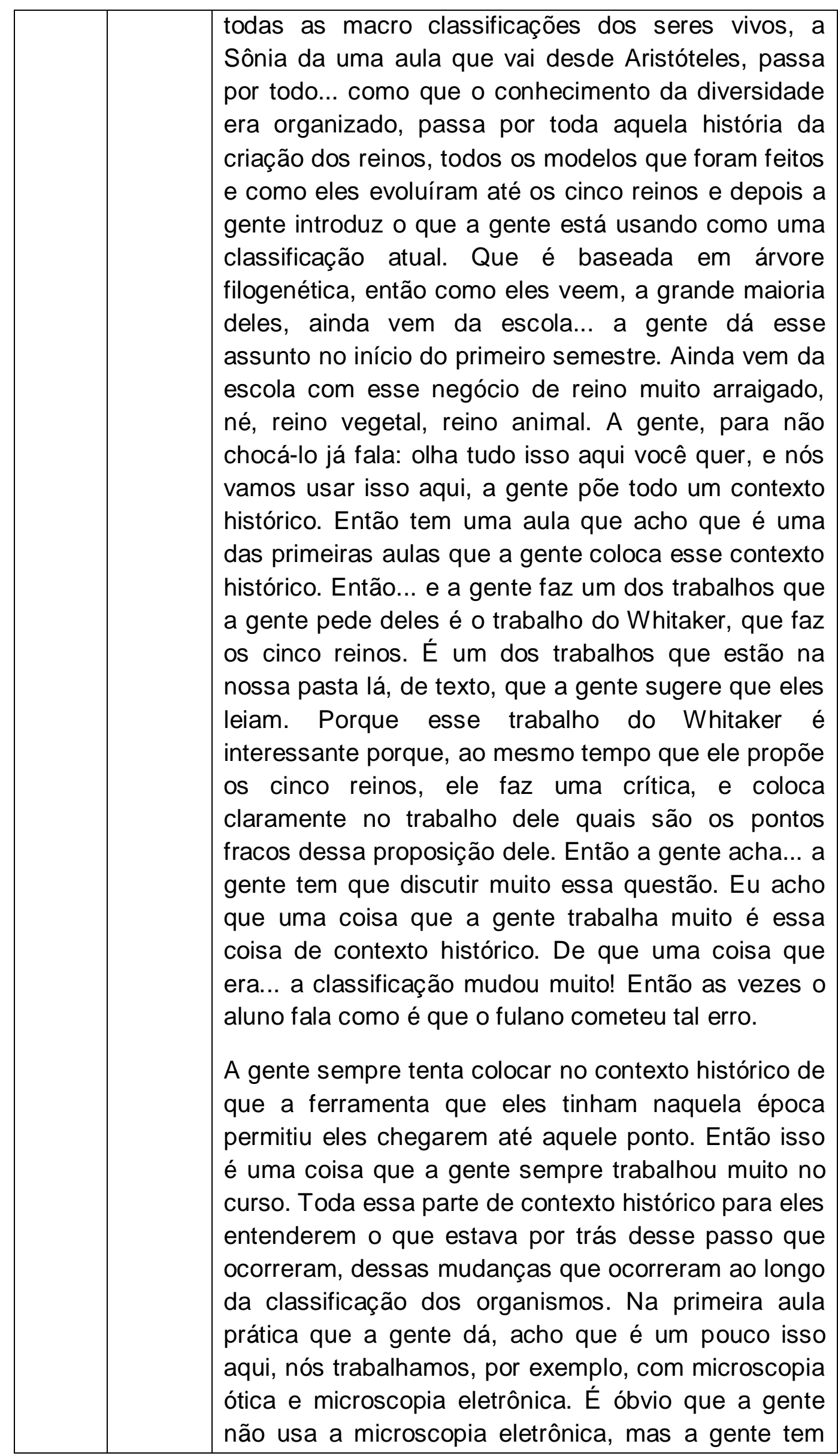




\begin{tabular}{|c|c|c|}
\hline & & $\begin{array}{l}\text { um material que eles tão observando no microscópio } \\
\text { óptico e eles têm esse mesmo material... um material } \\
\text { muito próximo que eles tem, a fotografia, nós } \\
\text { entregamos uma espécie de uma ficha com a } \\
\text { fotografia de uma microscopia eletrônica. Então eles } \\
\text { têm que tentarem ver o que eles conseguem ver } \\
\text { numa microscopia ótica e o que eles não conseguem } \\
\text { ver, e qual é o detalhamento que eles têm na } \\
\text { microscopia eletrônica e como poder interpretar essa } \\
\text { microscopia eletrônica que é muito diferente do que } \\
\text { eles veem no microscópio. então a gente tenta sim } \\
\text { fazer isso ao longo do curso. }\end{array}$ \\
\hline A7 & $05: 50$ & Eu: Isso. \\
\hline A8 & 05:51 & $\begin{array}{l}\text { Mariana: Uma coisa que a gente sempre fala que } \\
\text { também é um curso particular porque ele não tem um } \\
\text { livro texto. Como a gente trabalha com grupos que } \\
\text { tradicionalmente são estudados na botânica e outros } \\
\text { grupos que tradicionalmente são estudados na } \\
\text { zoologia, nós acabamos usando diferentes livros. } \\
\text { Livros da área de botânica, livros da área de zoologia. } \\
\text { No começo a gente também teve um pouco essa } \\
\text { dificuldade, por que os termos são diferentes a } \\
\text { terminologia é diferente e a gente, os professores } \\
\text { tivemos que ajustar a linguagem que nós da botânica } \\
\text { tínhamos um nome, a zoologia tinha outro nome. Até } \\
\text { os grupos tem nomes diferentes na zoologia e na } \\
\text { botânica. } \\
\text { Tem grupos que têm linhagens fotossintetizantes e } \\
\text { não fotossintetizantes, então a ideia do curso surgiu } \\
\text { um pouco disso, porque eles iam, uma parte do grupo } \\
\text { na zoologia e uma parte do grupo na botânica. Eu } \\
\text { sempre achei isso um completo disparate, não faz } \\
\text { sentido isso. } \\
\text { A ideia desse curso surgiu um pouco disso de tentar } \\
\text { dar um contexto mais... }\end{array}$ \\
\hline A9 & 06:59 & Eu: Geral. \\
\hline A10 & 07:00 & $\begin{array}{l}\text { Mariana: ... geral e filogenético para aquele grupo. } \\
\text { Sem tentar dividir fotossintetizantes de não } \\
\text { fotossintetizantes. Como a gente usa livros diferentes, } \\
\text { linguagens diferentes a gente fala logo de início para }\end{array}$ \\
\hline
\end{tabular}




\begin{tabular}{|c|c|c|}
\hline & & $\begin{array}{l}\text { eles que existem divergências entre as bibliografias e } \\
\text { que eles têm que aprender a olhar aquilo } \\
\text { criticamente. Então é... isso a gente sempre coloca } \\
\text { para eles desde o início e a gente sugere que eles } \\
\text { consultem diferentes fontes.Como todo esse processo } \\
\text { de classificação mais atual ainda tá muito fluido, ainda } \\
\text { tá mudando, a gente sempre coloca que ele deve } \\
\text { avaliar tudo muito criticamente. O fato de estar no } \\
\text { livro não significa que daqui dois meses não vá estar } \\
\text { tudo diferente. Então que eles têm que ter uma } \\
\text { postura muito crítica em relação à bibliografia e poder } \\
\text { ficar atentos a essa questão de mudança do } \\
\text { conhecimento. Com isso a gente trabalha bem no } \\
\text { curso, acho que todos esses pontos ai... têm alguns } \\
\text { portfólios... }\end{array}$ \\
\hline A11 & 08:08 & $\begin{array}{l}\text { Eu: De qualquer forma eles são todos muito } \\
\text { enraizados. Ė difícil até separar e durante as aulas é } \\
\text { mais difícil ainda. Eu queria só uma pergunta que não } \\
\text { está aqui. Desde quando há essa disciplina? A } \\
\text { senhora sabe? }\end{array}$ \\
\hline A12 & $08: 22$ & $\begin{array}{l}\text { Mariana: Ela foi... está no quinto ano. Ela entrou no } \\
\text { currículo novo logo no primeiro ano. É... }\end{array}$ \\
\hline A13 & $08: 35$ & Eu: Acho que faz uns 3 anos? \\
\hline A14 & $08: 37$ & $\begin{array}{l}\text { Mariana: Acho que já tem turma formada. } 2007 \ldots \\
\text { 2008. Ela começou em 2007. Nós demos o quinto } \\
\text { ano esse ano. }\end{array}$ \\
\hline A15 & $08: 55$ & $\begin{array}{l}\text { Eu: A segunda pergunta a senhora quase já } \\
\text { respondeu. Em que estágio da formação do biólogo } \\
\text { seria importante introduzir estes aspectos? }\end{array}$ \\
\hline A16 & 09:04 & $\begin{array}{l}\text { Mariana: Eu acho que desde cedo. Quanto antes } \\
\text { melhor. É o que a gente faz... a gente pega entrando } \\
\text { né. }\end{array}$ \\
\hline A17 & $09: 12$ & $\begin{array}{l}\text { Eu: É um dos meus interesses o que eles trouxeram } \\
\text { do ensino médio. É que eu não posso acompanhar } \\
\text { até eles saírem ou um número maior de turmas. }\end{array}$ \\
\hline A18 & $09: 27$ & $\begin{array}{l}\text { Mariana: Até se você quiser... agora no início do ano } \\
\text { que vem, se você quiser assistir aula é legal. Deve } \\
\text { ser início de março. Na primeira semana. Começa }\end{array}$ \\
\hline
\end{tabular}




\begin{tabular}{|c|c|c|}
\hline & & $\begin{array}{l}\text { normalmente na última semana de fevereiro, dia } 27 \text {. } \\
\text { Nessa primeira semana a gente não dá aula. A gente } \\
\text { começa na primeira semana de março. }\end{array}$ \\
\hline A19 & $10: 01$ & $\begin{array}{l}\text { Eu: Certo, eu entro em contato com a senhora. } \\
\text { Segunda pergunta só para a gente seguir o padrão } \\
\text { aqui. A senhora diria que tais questões são } \\
\text { trabalhadas na sua disciplina. Isso já foi respondido, } \\
\text { né. De maneira implícita ou explícita? }\end{array}$ \\
\hline A20 & $10: 15$ & Mariana: Explícita! \\
\hline A21 & $10: 16$ & $\begin{array}{l}\text { Eu: Explícito né! Também já foi respondido. Dos sete } \\
\text { aspectos que foram trabalhados aí, a senhora já falou } \\
\text { que provavelmente quais foram trabalhados e } \\
\text { considera que todos tenham sido, né. Em que } \\
\text { momentos? A senhora lembra... teve esse momento } \\
\text { inicial das primeiras aulas... }\end{array}$ \\
\hline A22 & $10: 40$ & $\begin{array}{l}\text { Mariana: A gente trabalha isso ao longo de todo o } \\
\text { curso na verdade. Com essa aula da Sônia a gente } \\
\text { deixa bem claro, com essas duas primeiras aulas, a } \\
\text { gente deixa bem claro essa questão que eles vão } \\
\text { encontrar bibliografias discrepantes, não só questão } \\
\text { de terminologia, mas eles vão encontrar informação } \\
\text { que é diferente, que é conflitante, entre um e outro. } \\
\text { Como a gente usa vários livros de texto e não tem um } \\
\text { único manual e nós não temos apostila. A gente logo } \\
\text { de início coloca isso ai. Da dificuldade que eles vão } \\
\text { ter, certas informações, que eles vão ter uma } \\
\text { avaliação crítica e todo esse contexto histórico é } \\
\text { colocado logo de início. Mas ao longo de todo o curso } \\
\text { a gente trabalha coisas diferentes. A gente está } \\
\text { sempre falando de plano. Olha, fulano disse isso, } \\
\text { ciclano disse aquilo. Então quem está certo a gente } \\
\text { ainda não sabe. Então a gente tenta ao longo de } \\
\text { todo o conteúdo, a gente vai recolocando isso. }\end{array}$ \\
\hline A23 & $12: 00$ & $\begin{array}{l}\text { Eu: É... durante as avaliações, estas questões } \\
\text { também são questionadas, exige-se alguma coisa do } \\
\text { aluno que ele escreva, disserte, apresente. Como } \\
\text { avaliação? Como processo avaliativo? }\end{array}$ \\
\hline A24 & $12: 17$ & $\begin{array}{l}\text { Mariana: Certamente a primeira que a gente acaba } \\
\text { colocando um pouco essa parte, que a gente tem } \\
\text { essa parte mais histórica no início. Na segunda e na }\end{array}$ \\
\hline
\end{tabular}




\begin{tabular}{|c|c|c|}
\hline & & $\begin{array}{l}\text { terceira talvez menos. Também acho que sim porque } \\
\text { normalmente a gente tenta não ser muito pontual... } \\
\text { colocar um pedaço de um texto, uma frase, ou } \\
\text { alguma informação que eles tem que elaborar em } \\
\text { cima daquilo. }\end{array}$ \\
\hline A25 & $12: 49$ & Eu: Ah... claro! \\
\hline A26 & $12: 49$ & $\begin{array}{l}\text { Mariana: Então a gente acaba trabalhando um pouco } \\
\text { disso dentro de todas essas questões a gente tem... }\end{array}$ \\
\hline A27 & $13: 00$ & $\begin{array}{l}\text { Eu: Os quatro professores estão presentes durante } \\
\text { todo o curso? É modulado? }\end{array}$ \\
\hline A28 & 13:05 & $\begin{array}{l}\text { Mariana: Não é... Nós quatro estamos presentes } \\
\text { praticamente em todas as aulas, especialmente na } \\
\text { aula prática. Na teórica nem sempre a gente está os } \\
\text { quatro presentes. E, às vezes tem um congresso, tem } \\
\text { uma reunião então varia um pouco. De modo geral a } \\
\text { participação é ao longo de todo o curso e a gente não } \\
\text { tem um módulo onde um entra dá aula e vai embora. } \\
\text { O aluno tem contato com os quatro professores ao } \\
\text { longo de todo o curso. A Sônia um pouco menos } \\
\text { porque no ano passado ela teve várias viagens. Mas } \\
\text { de um modo geral é... No ano passado foi um ano } \\
\text { particular porque ela teve várias atividades fora. } \\
\text { Normalmente ela também fica presente quase que o } \\
\text { tempo todo. Porque justamente nas práticas a gente } \\
\text { tem é... muitos desses grupos tem por exemplo: } \\
\text { fotossintetizantes não-fotossintetizantes é importante } \\
\text { que tenha... Agora a gente tá bem mais afiados com } \\
\text { os materiais, mas no começo era muito importante } \\
\text { que tivesse alguém da botânica e alguém da zoo para } \\
\text { dar aula. Aparecem coisas que a gente não tá } \\
\text { acostumada. }\end{array}$ \\
\hline A29 & $14: 20$ & Eu: A gente acaba se especializando muito... \\
\hline A30 & $14: 21$ & Mariana: É. Exatamente... \\
\hline A31 & $14: 23$ & Eu: Eu acho estas disciplinas ótimas para isso... \\
\hline A32 & $14: 25$ & $\begin{array}{l}\text { Mariana: E como a gente reparou, as respostas são } \\
\text { muito boas, enfim... a gente trabalha todos os grupos, } \\
\text { a gente tem um material muito rico, a gente tem um } \\
\text { prática muito rica. Muitas vezes esse material vem do }\end{array}$ \\
\hline
\end{tabular}




\begin{tabular}{|c|c|c|}
\hline & & $\begin{array}{l}\text { campo. Então às vezes não é pouco e eles têm muito } \\
\text { interesse em saber. O que é isso? Qual a diferença? } \\
\text { Por isso que é bom ter três ou quatro professores na } \\
\text { sala para a gente poder suprir, porque, cada um fica } \\
\text { olhando um pouco. Tem coisa que eu fico olho e falo: } \\
\text { Não faço a menor ideia! Chama o Fábio, ai o Fábio } \\
\text { olha, às vezes ele olha com mais cuidado. O que é } \\
\text { verde chama a Mariana. Então é assim... a gente na } \\
\text { prática é importante que tenha pelo menos dois ou } \\
\text { três professores para não ter esse problema... Não } \\
\text { um problema, mas uma riqueza de material que as } \\
\text { vezes vem. }\end{array}$ \\
\hline A33 & $15: 20$ & $\begin{array}{l}\text { Eu: O que a senhora disse que esse conteúdo é... } \\
\text { principalmente na primeira avaliação e nas outras são } \\
\text { permeadas, a senhora lembra do aproveitamento dos } \\
\text { alunos, da participação dos alunos, um } \\
\text { desenvolvimento, alguma coisa assim... }\end{array}$ \\
\hline A34 & $15: 40$ & Mariana: Você diz na prova? \\
\hline A35 & $15: 41$ & $\begin{array}{l}\text { Eu: Na prova e, se lembrar, de algum episódio é } \\
\text { interessante... }\end{array}$ \\
\hline A36 & $15: 47$ & $\begin{array}{l}\text { Mariana: Eu acho assim... de um modo geral eles vão } \\
\text { bem na disciplina. Eu acho que a gente ajustou um } \\
\text { pouco o conteúdo. No primeiro ano foi muito pesado. } \\
\text { A tendência é você querer dar todo o conteúdo que } \\
\text { você dava antes, só que no fundo a gente tava } \\
\text { juntando o conteúdo de duas disciplinas diferentes } \\
\text { que é Criptógamas e Invertebrados I. Ai realmente, no } \\
\text { primeiro ano, a gente pesou um pouco a mão, a gente } \\
\text { sentiu que ficou muito pesada a disciplina e com o } \\
\text { tempo a gente foi ajustando o conteúdo. } \\
\text { Acho que a maioria deles vai bem, tem um } \\
\text { aproveitamento bom e tem mais facilidade de } \\
\text { responder estas perguntas onde ele tem que } \\
\text { interpretar mais do que uma coisa decoreba. Porque } \\
\text { decoreba é uma coisa que você sabe ou não sabe. } \\
\text { Então... }\end{array}$ \\
\hline A37 & $16: 42$ & $\begin{array}{l}\text { Eu: Exatamente... e mais específico durante... é que } \\
\text { é difícil por causa desta distância de tempo } \\
\text { principalmente... com relação a essas questões, } \\
\text { alguma discussão que tenha havido por parte dos }\end{array}$ \\
\hline
\end{tabular}




\begin{tabular}{|c|c|c|}
\hline & & alunos em sala de aula? \\
\hline A38 & $16: 56$ & $\begin{array}{l}\text { Mariana: Eles perguntam... é bem sintomático } \\
\text { assim... diurno eles perguntam muito menos, são } \\
\text { mais tímidos e fechados, mas eles vão melhor na } \\
\text { prova. O noturno é o contrário. Eles perguntam } \\
\text { muito... e ai o rendimento da prova é um pouco } \\
\text { menor. Eu não sei o motivo disso, mas é uma coisa } \\
\text { que a gente costuma... é... se você for pegar a média } \\
\text { de notas normalmente é isso... o diurno ter um } \\
\text { rendimento um pouco melhor nas provas, mas eles } \\
\text { interagem menos principalmente no começo. No } \\
\text { começo eles são um túmulo, não abrem a boca para } \\
\text { nada. E o noturno não! É bem mais participativo. }\end{array}$ \\
\hline A39 & $17: 54$ & Eu: Eu peguei o perfil deles de idade, trabalho... \\
\hline A40 & $17: 57$ & $\begin{array}{l}\text { Mariana: A gente sabe que o pessoal do noturno é } \\
\text { mais velho... trabalha. }\end{array}$ \\
\hline A41 & $17: 59$ & Eu: É um pouco mais velho e poucos trabalham. \\
\hline A42 & 18:04 & Mariana: Mais alguns trabalham! \\
\hline A43 & 18:05 & $\begin{array}{l}\text { Eu: Uns } 4 \text { ou } 5 \text { nessa turma que eu peguei, que } \\
\text { trabalham e são responsáveis pela renda total da } \\
\text { família. }\end{array}$ \\
\hline A44 & $18: 18$ & $\begin{array}{l}\text { Mariana: A impressão que a gente tem é que eles } \\
\text { são um pouquinho mais velhos. }\end{array}$ \\
\hline A45 & $18: 22$ & Eu: É um pouquinho mais velhos. \\
\hline A46 & $18: 22$ & $\begin{array}{l}\text { Mariana: E, por causa disso acho que também ficam } \\
\text { menos tímidos de perguntar. Inclusive este ano a } \\
\text { turma do noturno, tinha dia que era difícil dar aula } \\
\text { para eles de tanto que eles perguntavam. Achava } \\
\text { que não ia conseguir acabar a aula, porque... assim, } \\
\text { eles tem muito interesse e como... a gente tem trazido } \\
\text { para o curso um conhecimento de ponta. Então é } \\
\text { comum a gente buscar trabalho que saiu há um mês. } \\
\text { Porque é uma área que está, realmente, muito fluida } \\
\text { esta parte de classificação de grandes filos, de } \\
\text { grandes grupos, tem muita coisa que está sendo } \\
\text { descoberta e descrita agora e, as vezes, a gente } \\
\text { muda, de um ano para o outro, muda a classificação } \\
\text { em função destas complicações, então eles têm muita }\end{array}$ \\
\hline
\end{tabular}




\begin{tabular}{|c|c|c|}
\hline & & $\begin{array}{l}\text { curiosidade por causa disso, eu acho! E ai eles } \\
\text { acabam perguntando bastante. }\end{array}$ \\
\hline A47 & 19:19 & $\begin{array}{l}\text { Eu: Era basicamente isso! Para finalizar, queria saber } \\
\text { se a senhora tem o interesse de perguntar alguma } \\
\text { coisa, do processo de avaliação... }\end{array}$ \\
\hline A48 & 19:28 & $\begin{array}{l}\text { Mariana: Eu acho que seria interessante para a } \\
\text { gente, por exemplo, estas questões aqui. A gente } \\
\text { sabe que a gente trabalha, mas a gente não sabe o } \\
\text { quanto isso passa para os alunos, né? O que } \\
\text { realmente eles percebem disso aqui! A gente fala } \\
\text { muito! A gente fala claramente todas estas questões, } \\
\text { uma coisa explícita mesmo, não é uma coisa que está } \\
\text { implícita. A gente realmente fala estas questões e } \\
\text { tudo. Questões da avaliação crítica do } \\
\text { conhecimento... que tem interpretação... para a gente } \\
\text { seria interessante saber se realmente está passando } \\
\text { para eles, se eles tem esta percepção. Minha } \\
\text { curiosidade maior seria essa. Se você pudesse dar } \\
\text { um feedback para a gente. Seria bem legal! }\end{array}$ \\
\hline A49 & $20: 18$ & $\begin{array}{l}\text { Eu: Como eu já analisei... estou em processo de } \\
\text { análise dos resultados dos alunos... }\end{array}$ \\
\hline A50 & $20: 23$ & Mariana: Você tá fazendo com vários cursos ou não? \\
\hline A51 & $20: 25$ & Eu: Não! Só na biologia e só com essa turma. \\
\hline A52 & $20: 29$ & $\begin{array}{l}\text { Mariana: Sim, mas você pegou todos os cursos que } \\
\text { eles tiveram, as disciplinas ou pegou só uma? }\end{array}$ \\
\hline A53 & $20: 36$ & $\begin{array}{l}\text { Eu: Agora que eu estou pegando os professores de } \\
\text { todas as disciplinas. Eu fiz a entrevista com eles no } \\
\text { primeiro dia de aula, antes deles terem uma aula com } \\
\text { o Amabis e com a Maria Elice que iam tratar um } \\
\text { pouco desses assuntos. O Amabis de método } \\
\text { científico também e no final do primeiro semestre. }\end{array}$ \\
\hline A54 & $20: 44$ & $\begin{array}{l}\text { Mariana: Eu acho que isso é uma característica dos } \\
\text { professores da USP. Porque todos nós somos } \\
\text { pesquisadores, sente isso diariamente. Porque as } \\
\text { verdades não são absolutas a gente tá careca de } \\
\text { saber. Então, realmente a gente passa isso que você } \\
\text { falou. }\end{array}$ \\
\hline
\end{tabular}




\begin{tabular}{|c|c|c|}
\hline A55 & $21: 03$ & $\begin{array}{l}\text { Eu: E passa sem perceber, porque é o nosso } \\
\text { cotidiano né, então acaba passando sem perceber. }\end{array}$ \\
\hline A56 & $21: 13$ & $\begin{array}{l}\text { Mariana: O crivo do vestibular, ele realmente } \\
\text { funciona, porque nos pegamos alunos muito bons. }\end{array}$ \\
\hline A57 & $21: 20$ & Eu: São muito bons mesmo. \\
\hline A58 & $21: 21$ & Mariana: E em épocas diferentes! \\
\hline A59 & $21: 23$ & $\begin{array}{l}\text { Eu: Essa é uma das coisas que eu estou levantando } \\
\text { e vou ressaltar, que não são quaisquer alunos. É um } \\
\text { nível bem elevado, gente do Brasil todo, no nosso } \\
\text { caso não, mas sempre vem alguma pessoa de fora só } \\
\text { para isso. E é isso que estou encontrando com os } \\
\text { alunos da gente. Não como professor deles, mas fui } \\
\text { monitor... }\end{array}$ \\
\hline A60 & $21: 54$ & $\begin{array}{l}\text { Mariana: No começo do ano que vem, possivelmente } \\
\text { essas aulas são dadas nas duas primeiras semanas } \\
\text { de março, e se você quiser ter uma idéia melhor... }\end{array}$ \\
\hline A61 & $22: 09$ & Eu: Quero sim! \\
\hline
\end{tabular}

Transcrição da entrevista com o professor Dr. Luis Eduardo Soares Netto

\begin{tabular}{|l|l|l|}
\hline Turno & Tempo & \multicolumn{1}{c|}{ Fala } \\
\hline B1 & 00:00 & $\begin{array}{l}\text { Eu: Vão ser quatro perguntas... que eu te mandei não } \\
\text { é? E alguma coisa que venha a surgir para saber } \\
\text { mais o que aconteceu nas aulas. Porque a pesquisa } \\
\text { que eu estou fazendo é o que mudou na concepção } \\
\text { dos alunos sobre ciências, sobre o que eles } \\
\text { entendem sobre ciência. E os que eu pesquisei foram } \\
\text { do primeiro semestre que o senhor foi professor. }\end{array}$ \\
$\begin{array}{l}\text { A primeira pergunta. Eu queria que o senhor } \\
\text { discutisse brevemente sobre o ensino contextual de } \\
\text { ciências. Entre vários pesquisadores na área, } \\
\text { propõem que o ensino contextual de ciências } \\
\text { trabalhe, entre outras coisas, questões relacionadas a } \\
\text { isso daqui que eu vou apresentar para o senhor. } \\
\text { Brevemente... que os alunos compreendam a } \\
\text { diferença entre observação e inferência, compreenda } \\
\text { a distinção entre leis e teorias, que os alunos }\end{array}$ \\
\hline
\end{tabular}




\begin{tabular}{|c|c|c|}
\hline & & $\begin{array}{l}\text { entendam que a imaginação e criatividade também } \\
\text { fazem parte da ciência, que o conhecimento científico } \\
\text { é determinado por teorias, não é uma verdade } \\
\text { absoluta. Posso virar... }\end{array}$ \\
\hline B2 & 02:05 & Luis: Hum, hum ... \\
\hline B3 & 02:06 & $\begin{array}{l}\text { Eu: ....sofre influência cultural, e a gente encontra } \\
\text { muitas pessoas e muitos alunos acreditando que não } \\
\text { sofre influencia nenhuma, que o conhecimento } \\
\text { científico nunca é absoluto e a distinção entre a } \\
\text { Natureza da Ciência, que é tudo isso que envolve a } \\
\text { ciência, todos esses fatores que permeiam o } \\
\text { conhecimento científico e a investigação científica. } \\
\text { Pode até ficar com esse papel para acompanhar... } \\
\text { Dentre esses aspectos ai, o senhor lembra de alguma } \\
\text { coisa que vocês trabalharam durante as aulas, } \\
\text { alguma abordagem, como... Eu assisti à primeira aula } \\
\text { de vocês que a Maria Elice, que é minha orientadora } \\
\text { deu uma aula, o Amabis também, sobre... }\end{array}$ \\
\hline B4 & 02:51 & Luis: Métodos científicos! \\
\hline B5 & 02:52 & Eu: É! \\
\hline B6 & 02:57 & $\begin{array}{l}\text { Luis: É então... não sei se você chegou a ter o } \\
\text { material da disciplina. }\end{array}$ \\
\hline B7 & 03:02 & Eu: Peguei. \\
\hline B8 & 03:03 & Luis: Ele é todo baseado no... \\
\hline B9 & 03:09 & Eu: No livro do John Moore. \\
\hline B10 & 03:10 & $\begin{array}{l}\text { Luis: Exatamente. Ali a filosofia é... cada vez é mais } \\
\text { difícil você... se a gente pegar na biologia, na } \\
\text { genética, a quantidade de informação que é gerada é } \\
\text { monumental. Então é muito difícil você querer } \\
\text { acompanhar, né. O mais importante é querer } \\
\text { entender um pouco como o conhecimento é gerado, o } \\
\text { contexto... o momento histórico que é gerado, cultural } \\
\text { e... acho que está muito dentro disso mesmo, quer } \\
\text { dizer, acho que tem toda uma ideia de estudar um } \\
\text { pouco a genética num contexto histórico que é dado } \\
\text { na disciplina. A gente vai seguindo... todos os } \\
\text { conceitos que a gente vai abordar: padrão de } \\
\text { herança, dominância e recessividade, tudo que está... }\end{array}$ \\
\hline
\end{tabular}




\begin{tabular}{|c|c|c|}
\hline & & $\begin{array}{l}\text { a gente está abordando de uma forma histórica que } \\
\text { traz como o conhecimento é gerado, que é uma coisa } \\
\text { que a gente pode usar em outros momentos da } \\
\text { carreira dos alunos. }\end{array}$ \\
\hline B11 & 04:32 & Eu: Foi uma das disciplinas... \\
\hline B12 & 04:34 & $\begin{array}{l}\text { Luis: Isso é uma coisa que tá claramente... até eu } \\
\text { quando entrei. Eu quando entrei já... que foi adaptado } \\
\text { pela Lyria, pelo Carlos, pelo professor Mariano, né, } \\
\text { tudo isso eles que fizeram e na verdade foi } \\
\text { começando tudo. }\end{array}$ \\
\hline B13 & 04:56 & $\begin{array}{l}\text { Eu: E o senhor entrou, faz quanto tempo, nessa } \\
\text { disciplina? }\end{array}$ \\
\hline B14 & 05:01 & $\begin{array}{l}\text { Luis: É então... o que aconteceu foi o seguinte. } \\
\text { Quando eu entrei foi em noventa e oito. Essa } \\
\text { disciplina era uma disciplina de... oito créditos. } \\
\text { Porque era outra estrutura curricular... e a partir de } \\
\text { dois mil e sete houve uma remodelação para uma } \\
\text { nova estrutura onde você tem o núcleo básico e o } \\
\text { núcleo avançado. Ai a Genética, para poder se } \\
\text { adaptar ao núcleo básico foi reduzida de oito para } \\
\text { quatro créditos. Teve uma readaptação ai! Eu } \\
\text { comecei em noventa e oito mais assistindo e comecei } \\
\text { a dar aula mesmo em noventa e nove. Eu já estou a } \\
\text { um bom tempo ai.... }\end{array}$ \\
\hline B15 & 05:44 & Eu: É um bom tempo... \\
\hline B16 & $05: 45$ & $\begin{array}{l}\text { Luis: E na verdade existe uma... interação muito } \\
\text { forte, já chegou a ser até mais forte, entre a Genética } \\
\text { e a Biologia molecular. Na verdade a disciplina } \\
\text { genética tratada mais uma genética clássica. Ela vai } \\
\text { até o momento do... da descoberta de modos de } \\
\text { adição gênica. A partir da descoberta da estrutura do } \\
\text { DNA já é Biologia Molecular. No fundo é uma } \\
\text { genética também. }\end{array}$ \\
\hline B17 & $06: 24$ & Eu: No segundo semestre? \\
\hline B18 & $06: 25$ & $\begin{array}{l}\text { Luis: No terceiro semestre. } O \text { ideal é que fosse no } \\
\text { segundo, mas enfim, acabou que foi no terceiro. }\end{array}$ \\
\hline B19 & $06: 31$ & Eu: É bom para o aluno pegar um pouco mais de \\
\hline
\end{tabular}




\begin{tabular}{|c|c|c|}
\hline & & experiência... \\
\hline B20 & $06: 36$ & Luis: $E^{E} .$. não se discute muito. \\
\hline B21 & 06:41 & $\begin{array}{l}\text { Eu: Então é isso... Então uma outra pergunta que } \\
\text { seria complementar... o senhor concorda ou não que } \\
\text { esse tipo de abordagem, esse tipo de preocupação, } \\
\text { com esse contexto metacientífico, que envolve a } \\
\text { ciência, esteja presente na formação? }\end{array}$ \\
\hline B22 & 07:00 & $\begin{array}{l}\text { Luis: É fundamental... fundamental... deve ter, eu } \\
\text { acho. }\end{array}$ \\
\hline B23 & 07:04 & Eu: Em que momento? \\
\hline B24 & 07:07 & $\begin{array}{l}\text { Luis: Eu não sei... quer dizer... acho que em todo } \\
\text { momento a gente deve estar, a toda hora, } \\
\text { apresentando o conceito em relação a forma como } \\
\text { eles foram gerados. Eu não sei se você sabe se você } \\
\text { tem que seguir a cronologia de um jeito tão... como a } \\
\text { própria Genética segue, eu não sei se isso é ideal. } \\
\text { Isso não é unânime, isso é uma opinião... eu penso } \\
\text { assim. Eventualmente você pode não seguir uma } \\
\text { cronologia, mas mostrar que você pode achar que a... } \\
\text { a sequência de conceitos a serem apresentados não } \\
\text { necessariamente coincida com a cronologia. E... mas } \\
\text { de qualquer jeito você pode mostrar em cada } \\
\text { momento como os conceitos foram sendo gerados, } \\
\text { mesmo que isso não seja linear cronologicamente. } \\
\text { Eu gosto muito do livro do Griffiths, por exemplo. Eu } \\
\text { acho que o Griffiths tem uma abordagem muito legal } \\
\text { que eu acho que é bem legal para várias disciplinas } \\
\text { que a gente, do departamento, oferece. Acho que } \\
\text { essa ideia de mostrar como o conceito é gerado, } \\
\text { como aqueles conceitos, que hoje a gente assume, } \\
\text { no momento atual é aceito, como é que eles foram } \\
\text { gerados, num dado momento, num dado contexto. Eu } \\
\text { acho isso importantíssimo. Que mostra de novo que } \\
\text { não existe uma verdade absoluta, que isso pode ser } \\
\text { mudado, que isso é uma... que é uma verdade até } \\
\text { que alguém tem... um pouco do Thomas Kuhn né... } \\
\text { Que eu acho que a disciplina de genética... muito por } \\
\text { influência do professor Mariano e essa preocupação } \\
\text { de mostrar um pouco como que o conhecimento é } \\
\text { gerado... Thomas Kuhn é... Popper, todas essas }\end{array}$ \\
\hline
\end{tabular}




\begin{tabular}{|c|c|c|}
\hline & & $\begin{array}{l}\text { ideias são introduzidas né? } \\
\text { O começo basicamente é na Genética que tem essa } \\
\text { preocupação. Eu acho que tem aquela disciplina no } \\
\text { interunidades, agora eu não sei... também acho que } \\
\text { menciona um pouco. }\end{array}$ \\
\hline B25 & 09:20 & Eu: IEB? \\
\hline B26 & 09:21 & Luis: Não é fauna e flora? \\
\hline B27 & 09:22 & Eu: Fauna e flora também trabalha um pouco. \\
\hline B28 & 09:24 & $\begin{array}{l}\text { Luis: Acho que trabalha um pouco. E... então na } \\
\text { verdade eu acho importante que eles mostrem } \\
\text { mesmo que você não diga claramente quem é o } \\
\text { filósofo, mas deixa claro que não é uma verdade } \\
\text { absoluta, porque no fundo é o jeito de fazer. O cara } \\
\text { achar que aquilo é uma verdade, não vai fazer } \\
\text { ciência, não consegue fazer nada. Parece que é } \\
\text { imutável, que as coisas são imutáveis. }\end{array}$ \\
\hline B29 & 09:52 & $\begin{array}{l}\text { Eu: Então... só para seguir uma ordem, aqui que eu } \\
\text { estabeleci. Então, o senhor diria que estas questões } \\
\text { são trabalhadas ao longo da disciplina? Isso já foi } \\
\text { respondido! De maneira implícita ou explícita? }\end{array}$ \\
\hline B30 & 10:11 & $\begin{array}{l}\text { Luis: Explícita! Até nas apostilas né, que os alunos } \\
\text { leem é muito claro isso... faz parte do próprio texto } \\
\text { base da disciplina né. Está totalmente dentro. }\end{array}$ \\
\hline B31 & $10: 33$ & Eu: O texto do Moore é bem explícito mesmo. \\
\hline B32 & $10: 43$ & $\begin{array}{l}\text { Luis: Tem umas coisas que eu, até conversando com } \\
\text { o Mariano... até eu acho que, as vezes eu acho } \\
\text { que... essa é uma das coisas que eu não consegui } \\
\text { ainda... é... você lê um pouco o texto do Moore, ele é } \\
\text { ótimo, mas ele tem algumas coisas que as vezes ele } \\
\text { toma partido de algum lado né... Você pega um } \\
\text { exemplo, tem um dado momento, quando tem, por } \\
\text { exemplo, os mendelistas e os biometristas né. Ele } \\
\text { coloca os biometristas como os vilões da história. Os } \\
\text { dois lados da histórias, o lado bom e o lado ruim, isso } \\
\text { é uma coisa meio... sempre uma coisa... um lado é o } \\
\text { certo e o outro o errado. Mas enfim, a gente sabe que } \\
\text { não é assim né... na realidade é mais complexa né. } \\
\text { Quer dizer... então acho que não devia tomar partido }\end{array}$ \\
\hline
\end{tabular}




\begin{tabular}{|c|c|c|}
\hline & & $\begin{array}{l}\text { né. Muitas vezes parece que tá tomando partido e } \\
\text { parece que um lado tá agindo cientificamente e o } \\
\text { outro não tá. Isso não me parece muito bom, porque, } \\
\text { você tá dentro de uma visão científica de história da } \\
\text { ciência, não tentar tomar partido, tentar... isso até } \\
\text { como a Maria Elice tava comparando, ela colocou até } \\
\text { essa falta, colocou um artigo de como a gente não } \\
\text { tem tempo na verdade de discutir um pouco isso... } \\
\text { talvez fazer uma adaptação, talvez. Na apostila tinha } \\
\text { algumas coisas estereotipadas né, de... de.... mas mas } \\
\text { não era isso que eu estava querendo lembrar, mas } \\
\text { tudo bem, depois se eu lembrar eu falo. }\end{array}$ \\
\hline B33 & $12: 59$ & $\begin{array}{l}\text { Eu: } \mathrm{E} \text { isso acaba influenciando no que o aluno vai } \\
\text { compreendendo, na concepção do aluno. }\end{array}$ \\
\hline B34 & 13:05 & $\begin{array}{l}\text { Luis: É! Fica subjetivo e não fica uma coisa objetiva } \\
\text { né. Até você pensar na história da ciência como uma } \\
\text { ciência em si né, tem que tratar com os fatos e tomar } \\
\text { cuidado com o que é interpretação dos fatos e o que } \\
\text { é fato mesmo. Não tem jeito também. Você tem que } \\
\text { se policiar com isso. Na apostila tem momentos que } \\
\text { são muito fortes. Você vê claramente... esse é o } \\
\text { momento na hora que você... claro é esse conflito de } \\
\text { dois grupos, os biometristas e os mendelistas, fica } \\
\text { muito claro isso. }\end{array}$ \\
\hline B35 & $13: 52$ & $\begin{array}{l}\text { Eu: E quanto as avaliações? Se houve alguma } \\
\text { modificação do ano passado para cá, eu queria que o } \\
\text { senhor se lembrasse do ano passado. Nas } \\
\text { avaliações, houve essa... vocês tinham a intenção de } \\
\text { avaliar esse tipo de concepção, se os alunos } \\
\text { aprenderam ou não. }\end{array}$ \\
\hline B36 & $14: 16$ & $\begin{array}{l}\text { Luis: Então, não era... na avaliação a gente tenta... } \\
\text { tem a preocupação com os conceitos específicos de } \\
\text { genética. Então, padrão de herança, conceito de gene } \\
\text { alelo, primeira e segunda lei de Mendel, quer dizer } \\
\text { todos esses conceitos básicos de genética, na } \\
\text { verdade, a gente tem a preocupação de saber. A } \\
\text { forma como isso é aprendido é que a gente segue um } \\
\text { pouco essa ideia toda. No fundo, na verdade, o que é } \\
\text { avaliado são os conceitos de genética e não tanto } \\
\text { isso. Embora em alguns momentos da avaliação, na } \\
\text { primeira prova, tem uma pergunta muito clara }\end{array}$ \\
\hline
\end{tabular}




\begin{tabular}{|c|c|c|}
\hline & & $\begin{array}{l}\text { tratando também o conceito entre teoria, lei... } \\
\text { dedução, indução isso tá muito... isso é perguntado... } \\
\text { mas é... numa prova de... os conceitos são } \\
\text { explicitamente, não sei se eu estou sabendo o que é } \\
\text { explícito e implícito (risos), mas são claramente... } \\
\text { diretamente. }\end{array}$ \\
\hline B37 & $15: 30$ & $\begin{array}{l}\text { Eu: Diretamente perguntado... implícito está subjetivo } \\
\text { ali... }\end{array}$ \\
\hline B38 & $15: 34$ & $\begin{array}{l}\text { Luis: Então explicitamente, realmente tá numa } \\
\text { questão da primeira prova, que são seis questões. As } \\
\text { outras são basicamente conceitos genéticos, mas a } \\
\text { gente tenta usar muito do raciocínio que foi usado } \\
\text { pelo cientista quando ele descobriu (risos) aquele } \\
\text { conceito. }\end{array}$ \\
\hline B39 & $15: 58$ & Eu: Claro. \\
\hline B40 & $15: 59$ & $\begin{array}{l}\text { Luis: Não é só uma memorização dos conceitos, mas } \\
\text { uma coisa mais, dentro do possível de um raciocínio. }\end{array}$ \\
\hline B41 & $16: 10$ & $\begin{array}{l}\text { Eu: Basicamente era só isso. Se o senhor quiser me } \\
\text { perguntar alguma coisa para finalizar aqui... se o } \\
\text { senhor tem alguma dúvida. }\end{array}$ \\
\hline B45 & $16: 19$ & $\begin{array}{l}\text { Luis: Na verdade é curioso, você vez uma avaliação } \\
\text { dos alunos né... depois né... }\end{array}$ \\
\hline B46 & $16: 23$ & $\begin{array}{l}\text { Eu: É então... é o meu foco de pesquisa. Só que ai, } \\
\text { durante o processo todo, que eu estava começando } \\
\text { lá... Falaram: Não! Faça uma entrevista com os } \\
\text { professores, que não é o seu objetivo, mas eles vão... } \\
\text { com a informação deles você vai ter mais subsídios } \\
\text { para ver onde houveram essas mudanças, se } \\
\text { houveram. Alguma disciplina que talvez tenha pesado } \\
\text { mais ou menos para isso. }\end{array}$ \\
\hline B47 & $16: 57$ & Luis: É parte do processo! \\
\hline B48 & 17:04 & $\begin{array}{l}\text { Eu: Para então tentar ver o que os alunos, aqui da } \\
\text { biologia que estão iniciando, estão formando essa } \\
\text { concepção, tentando compreender um pouco a } \\
\text { ciência. Não só... }\end{array}$ \\
\hline B49 & $17: 38$ & Luis: Mas mudou algum dos conceitos deles, não \\
\hline
\end{tabular}




\begin{tabular}{|c|c|c|}
\hline & & mudou nada? \\
\hline B50 & $17: 53$ & $\begin{array}{l}\text { Eu: Alguns resultados que outros pesquisadores } \\
\text { tiveram, com outros... outras, outros alunos de pós- } \\
\text { graduação, de ensino médio, eles encontraram } \\
\text { poucas mudanças. Eu encontrei, considero que } \\
\text { tenha encontrado mudanças consideráveis, pelo } \\
\text { menos. Só que também, tem... o nosso aluno, aqui da } \\
\text { USP, já é um aluno muito selecionado. Já passaram } \\
\text { por um teste muito grande, que é a FUVEST. Então é } \\
\text { tudo isso que eu estou tentando ver. Eu gostei muito } \\
\text { dos resultados que tiveram nesse um semestre. }\end{array}$ \\
\hline B51 & 18:27 & $\begin{array}{l}\text { Luis: A sua avaliação é de conceitos relacionados a } \\
\text { esse tipo de coisa, não a conceitos específicos? }\end{array}$ \\
\hline B52 & $18: 33$ & $\begin{array}{l}\text { Eu: Não! Não conceitos de cada disciplina. Técnicos! } \\
\text { É mais sobre metaciência. Que é discutir sobre a } \\
\text { ciência e tudo que a envolve. }\end{array}$ \\
\hline B53 & $18: 46$ & $\begin{array}{l}\text { Luis: O processo científico mesmo né. Hipótese, } \\
\text { teoria... eles usam teoria como hipótese né! }\end{array}$ \\
\hline B54 & $18: 54$ & $\begin{array}{l}\text { Eu: É! Então é tudo isso que eu to querendo } \\
\text { investigar! É claro que é um grupo pequeno de } \\
\text { alunos, é uma pequena amostra... mas, para tentar } \\
\text { detectar onde a gente pode melhorar ou o que pode } \\
\text { ser potencializado, pode ser utilizado... }\end{array}$ \\
\hline B55 & 19:18 & Luis: Pô legal! João né? \\
\hline B56 & 19:19 & Eu: João, isso! \\
\hline B57 & 19:22 & $\begin{array}{l}\text { Luis: Acho que era mais isso! Fiquei curioso. (risos) } \\
\text { A gente não tem certeza se está fazendo certo ou não } \\
\text { tá, o que tem que melhorar. Acho importante esse } \\
\text { tipo de... na área... a gente faz muitas coisas } \\
\text { intuitivamente né, a verdade é essa. Quando a gente } \\
\text { é contratado, a gente é selecionado por todo um } \\
\text { passado na pesquisa né. Na parte de ensino é uma } \\
\text { coisa que a gente vai... a gente faz muito } \\
\text { intuitivamente e... e eu acho que cada vez mais é } \\
\text { muito um problema de geração... eu sinto um pouco } \\
\text { isso. Acho que a gente tem que olhar um pouco, } \\
\text { pensar um pouco mais se está agindo corretamente } \\
\text { ou não. Tá mudando muito rápido também, os meios }\end{array}$ \\
\hline
\end{tabular}




\begin{tabular}{|c|c|c|}
\hline & & $\begin{array}{l}\text { de comunicação de mídia, de... Realmente acho que, } \\
\text { que... talvez modernizar um pouco mais, talvez a } \\
\text { forma, não sei. Na verdade são preocupações que } \\
\text { não tem resposta. Também acho que esse tipo de } \\
\text { abordagem é importante. Trabalhar do modo } \\
\text { científico também a parte de ensino. Não ficar tanto } \\
\text { no eu acho. A gente faz muito isso. }\end{array}$ \\
\hline B58 & $20: 49$ & $\begin{array}{l}\text { Eu: Essa preocupação já é muito importante. Uma } \\
\text { hora a gente vai atrás, numa coisinha aqui. }\end{array}$ \\
\hline B59 & $20: 57$ & $\begin{array}{l}\text { Luis: O duro é que a gente faz muita... a organização } \\
\text { do sistema é duro porque a gente faz muita coisa e } \\
\text { acaba não fazendo nada muito bem. A gente tem que } \\
\text { fazer pesquisa, ensino, administrar e a gente faz um } \\
\text { monte de coisa e é difícil fazer tudo bem feito. Eu vejo } \\
\text { muito alguns colegas de fora, o da Espanha então, o } \\
\text { cara é contratado mais, principalmente, para dar aula. } \\
\text { Eu não acho muito boa essa visão total, mas um } \\
\text { pouco... é difícil a pessoa... é muita coisa, realmente } \\
\text { o que a gente tem que fazer aqui... }\end{array}$ \\
\hline B60 & $21: 45$ & Eu: São habilidades diferentes... \\
\hline B61 & $21: 47$ & $\begin{array}{l}\text { Luis: É! Eu acho que eles se integram muito, ensino } \\
\text { e pesquisa, acho importantíssimo... falando de ciência } \\
\text { e tudo, o aluno ter aula com um cientista, eu acho } \\
\text { importante. A vivência é uma coisa importante né... e } \\
\text { eu acho importante. Não adianta o cara ser um cara } \\
\text { super brilhante e... e ai conciliar essas coisas não é } \\
\text { trivial as vezes. A carga de coisas que a gente faz... } \\
\text { (risos) }\end{array}$ \\
\hline B62 & $22: 23$ & Eu: Bom é isso! Mais alguma coisa? \\
\hline B63 & $22: 28$ & Luis: Não! \\
\hline
\end{tabular}

Transcrição da entrevista com o professor Dr. Paulo Takeo Sano

\begin{tabular}{|l|l|l|}
\hline Turno & Tempo & \multicolumn{2}{|c|}{ Fala } \\
\hline C1 & $00: 00$ & $\begin{array}{l}\text { Eu: Queria que o senhor discutisse brevemente } \\
\text { sobre o chamado ensino contextual de ciências. } \\
\text { Entre outros pesquisadores, uma das minhas } \\
\text { referências, o Norman Lederman, propõe que o }\end{array}$ \\
\hline
\end{tabular}




\begin{tabular}{|c|c|c|}
\hline & & $\begin{array}{l}\text { ensino contextual seja feito por meio de abordagem } \\
\text { em sala de aula, dessas questões metacientíficas. } \\
\text { Tais como os sete aspectos da Natureza da Ciência } \\
\text { (que apresentei impresso) que seriam importantes } \\
\text { para serem trabalhados no ensino. Eu queria saber } \\
\text { se durante as aulas o senhor trabalhou, ou os outros } \\
\text { professores trabalharam, se preocuparam em } \\
\text { promover debates, discussões dessas características } \\
\text { da ciência. }\end{array}$ \\
\hline $\mathrm{C} 2$ & 02:50 & $\begin{array}{l}\text { Paulo: Tá! Assim... vou ter que contextualizar um } \\
\text { pouco para você entender qual o espírito da } \\
\text { disciplina para você entender um pouquinho. } \\
\text { Inicialmente, "Fauna, Flora e Ambiente" surgiu como } \\
\text { uma disciplina com a expectativa de agru... de } \\
\text { promover um... uma visão integrada e integradora } \\
\text { dos elementos fauna, flora e ambiente os elementos } \\
\text { naturais né. Nisso eu estou falando que agente vai } \\
\text { trabalhar com o macro universo. O objeto de trabalho } \\
\text { da disciplina é sempre do individuo para cima: } \\
\text { indivíduo, população, comunidade, ecossistema, } \\
\text { bioma. Então agente sempre vai trabalhar nesse } \\
\text { âmbito e a ideia era que sempre que eles tivessem } \\
\text { uma visão de início, uma visão integrada dos } \\
\text { eventos. A medida que o curso progredisse eles iam } \\
\text { ficando cada vez mais se especializando em uma ou } \\
\text { outra coisa e acabariam não vendo as coisas de } \\
\text { maneira integrada, de maneira que... a fauna } \\
\text { depende da flora, por sua vez eles são } \\
\text { interdependentes e também estão em um contexto } \\
\text { ambiental que influencia e é influenciado por esses } \\
\text { elementos. Inicialmente era só esse o contexto! Com } \\
\text { o tempo é... agente buscou que a disciplina cobrisse } \\
\text { algumas lacunas de formação nessa linha da } \\
\text { formação do cientista ou do olhar científico. Porque } \\
\text { era uma coisa que era importante para nós e para as } \\
\text { outras disciplinas, seria interessante promover isso } \\
\text { para eles poderem dar continuidade a partir de um } \\
\text { patamar. Então a disciplina está como ela está hoje, } \\
\text { como no ano passado, então mudou muito pouco. } \\
\text { Ela tem essa intenção, é uma questão de } \\
\text { intencionalidade mesmo, de prover essa introdução } \\
\text { ao universo da cultura científica, vamos chamar } \\
\text { assim. Por conta disso a disciplina não tem um }\end{array}$ \\
\hline
\end{tabular}




\begin{tabular}{|c|}
\hline 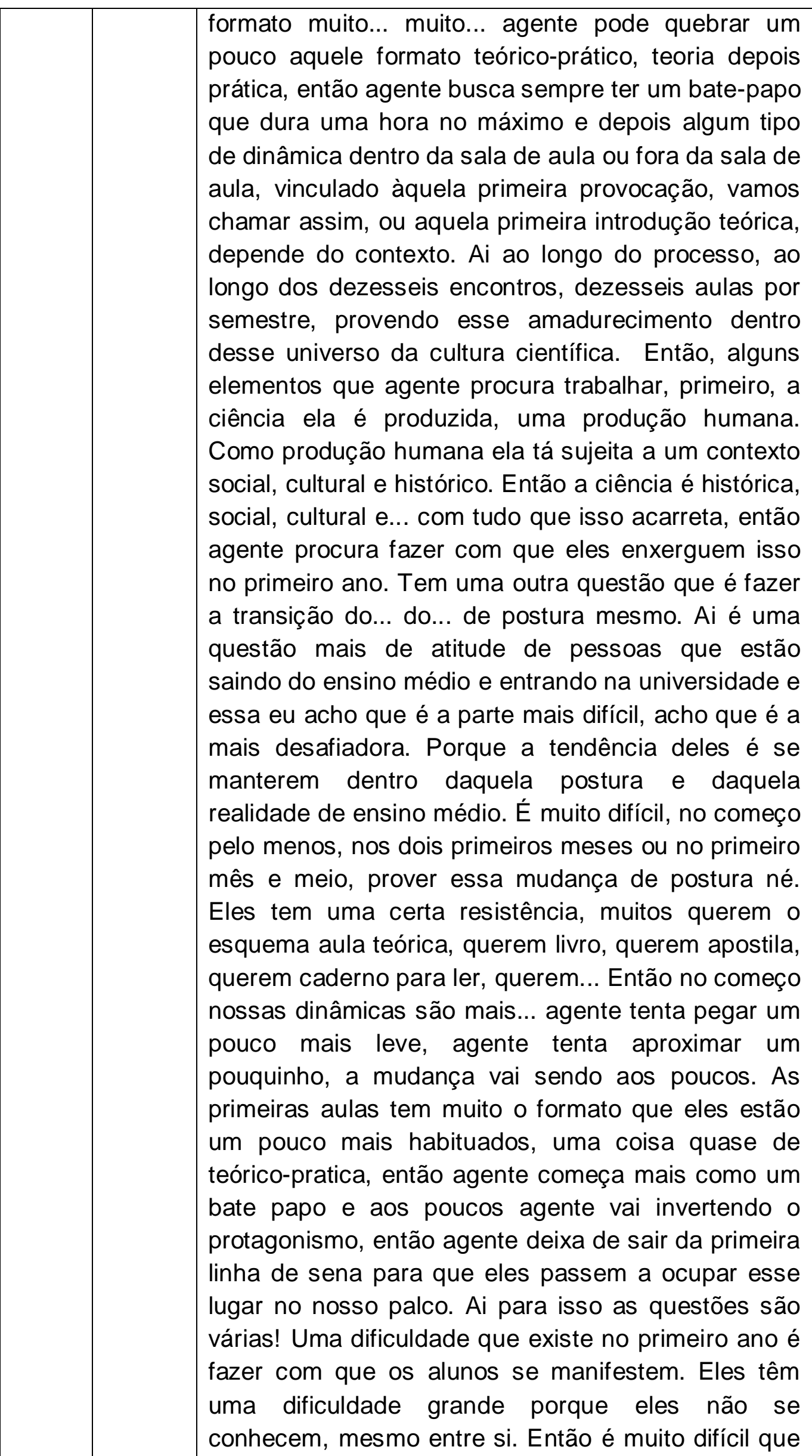 \\
\hline
\end{tabular}




\begin{tabular}{|l|l|}
\hline & $\begin{array}{l}\text { eles exponham individualmente seu ponto de vista ou } \\
\text { suas concepções. Então o que agente usa muito, } \\
\text { principalmente no começo, é o trabalho em grupo e a } \\
\text { formação de grupos para expressar opiniões. Ai eles } \\
\text { se escondem ou se... }\end{array}$ \\
\hline C3 & $\begin{array}{l}\text { Eu: Se sentem mais confortáveis! } \\
\text { C4 }\end{array}$ \\
$\begin{array}{l}\text { Paulo: É! Dentro da opinião do grupo. Então, não } \\
\text { acha que, penso assim, não sou eu, mas meu grupo } \\
\text { nesse contexto que agente tenta entrar com a } \\
\text { discussão de como a ciência é produzida, como } \\
\text { construção humana, cultural, histórica, etc, etc. E... } \\
\text { é... de uns três ou quatro anos para cá agente } \\
\text { promoveu uma mudança na disciplina, uma mudança } \\
\text { de... de eixo, porque antes estava num foco quase } \\
\text { que só ecológico, então agente dava um retrato do } \\
\text { presente, de como as coisas estavam. Então as } \\
\text { coisas de ambiente, fauna, flora o que eram as } \\
\text { funções biológicas... E a uns quatro anos agente } \\
\text { resolveu embutir o eixo evolutivo, que agente achou } \\
\text { que seria um ganho. Então a parte só ecológica eles } \\
\text { vão ter em todas as outras disciplinas que tem ai e } \\
\text { agente achou que faltava essa questão de ver fauna, } \\
\text { flora e ambiente presentes como resultado de um } \\
\text { processo. A partir dessa opção de conteúdo e de } \\
\text { linha metodológica também, muitas dessas questões } \\
\text { começam a ser trabalhadas de uma maneira um } \\
\text { pouco mais forte. Agente começa a trabalhar, por } \\
\text { exemplo, o significado de alguns conceitos e alguns } \\
\text { pré-conceitos que agente tem, então esse é o } \\
\text { primeiro grande desafio. Que, quando agente fala de } \\
\text { adaptação, quando agente fala de fatores bióticos e } \\
\text { abióticos, que são fatores limitantes e seleção natural } \\
\text { é... nesse fragmento agente vai ter que trabalhar isso } \\
\text { de maneira que os conceitos sejam mais ou menos } \\
\text { comuns. Então agente começou a perceber que, } \\
\text { quando agente falava do conceito de adaptação, um } \\
\text { tinha um conceito de adaptação mais evolutivo do } \\
\text { ponto de vista darwinista, outro, e que não é a } \\
\text { maioria, achava que adaptação era uma coisa muito } \\
\text { mais próxima do que os fisiologistas chamam de } \\
\text { aclimatação, entendeu, outros achavam que }\end{array}$ \\
\hline
\end{tabular}




\begin{tabular}{|c|c|c|}
\hline & & $\begin{array}{l}\text { adaptação é um fenômeno que independia... } \\
\text { independente do ambiente, a adaptação acontece, } \\
\text { viam a adaptação como uma... entre aspas uma } \\
\text { resposta a pressões ambientais dentro de um } \\
\text { contexto histórico ambiental. Então agente teve que... } \\
\text { e a partir disso, quer dizer, dessa primeira é... } \\
\text { tomada, levantamento das concepções prévias, ou } \\
\text { concepções alternativas que eles tinham, e ao } \\
\text { mesmo tempo das heterogeneidades das } \\
\text { concepções que eles tinham, agente começou a ver } \\
\text { essa questão. Então na verdade o que, que assim... } \\
\text { uns acham que a adaptação é isso, porque que uns } \\
\text { acham que adaptação é aquilo. Ai por exemplo, } \\
\text { umas das atividades que eles fizeram foi ler um texto } \\
\text { do Darwin, da "Origem das Espécies", quando ele } \\
\text { fala de adaptação. Eles leem, tem a produção de um } \\
\text { trabalhinho sobre isso e ai agente retoma isso numa } \\
\text { aula seguinte e fala olha: então hoje, quanto variou a } \\
\text { concepção de adaptação do Darwin e a concepção } \\
\text { sei lá, científico biológica. O contexto teve variação? } \\
\text { O que entrou de diferente, o que não entrou? Então } \\
\text { ai agente vai colocando essa perspectiva também } \\
\text { histórica e de mudança para os conceitos que eles } \\
\text { aprendem. Então eu acho que tem assim, algumas } \\
\text { coisas, são todas, eu vejo é... que eles tem assim... } \\
\text { agente de alguma forma tangencia, outras agente } \\
\text { ataca mais diretamente, mas é... tá nessa linha. }\end{array}$ \\
\hline C5 & $12: 43$ & $\begin{array}{l}\text { Eu: Essa... essa mudança que o senhor falou, dessa } \\
\text { disciplina nos últimos quatro anos, foi devida a } \\
\text { mudança da grade curricular ou não teve relação. }\end{array}$ \\
\hline C6 & $12: 52$ & $\begin{array}{l}\text { Paulo: Não! Não! Agente... na verdade o curso é } \\
\text { muito dinâmico, agente tá sempre repensando. Não é } \\
\text { um curso que agente tenha fechadinho e no ano } \\
\text { seguinte agente fala: é assim! Todo ano agente } \\
\text { muda alguma coisa. Só que ai essa grande mudança } \\
\text { veio dessa insatisfação que agente mesmo tinha de... } \\
\text { e os alunos também, quero deixar claro, dos rumos } \\
\text { do curso. Chegava no fim do curso agente fazia uma } \\
\text { avaliação e os alunos sempre pensavam: na verdade } \\
\text { foi legal porque eu adquiri essa visão integrada mas, } \\
\text { do ponto de vista dos conceitos, eu não aprendi } \\
\text { nenhum conceito novo. Eles sempre achavam que }\end{array}$ \\
\hline
\end{tabular}




\begin{tabular}{|c|c|c|}
\hline & & $\begin{array}{l}\text { não tinha aprendido nada novo porque na verdade } \\
\text { eles retomavam coisas que eles tinham visto no } \\
\text { colégio. O que em certa medida era verdade. Agente } \\
\text { no primeiro dia já falava para eles o curso não é } \\
\text { focado em conteúdo, o nosso foco não é o conteúdo. } \\
\text { Agente quer trabalhar com vocês a questão mais a } \\
\text { postura das atitudes frente à ciência, frente ao } \\
\text { conhecimento, frente a essas questões mais macro } \\
\text { do macro universo. E ai agente deixava claro: do } \\
\text { organismo, tecidos, órgãos, células vocês vão ver lá } \\
\text { na genética, não é aqui, agente não vai tocar nesse... } \\
\text { Quando agente fala diversidade agente não se } \\
\text { preocupa em abordar a diversidade genética, por } \\
\text { exemplo. Agente fala que ela existe, mas eles vão } \\
\text { trabalhar em outro momento. E também por conta de } \\
\text { quem faz o curso! Os professores, os cinco } \\
\text { professores que dão o curso, pelo menos três tem } \\
\text { um enfoque evolutivo nas suas próprias pesquisas } \\
\text { pessoais, então agente queria que fosse um pouco } \\
\text { mais... mais saliência né. }\end{array}$ \\
\hline C7 & 15:08 & $\begin{array}{l}\text { Eu: Os professores são: o senhor, o professor } \\
\text { Márcio... }\end{array}$ \\
\hline C8 & $15: 10$ & $\begin{array}{l}\text { Paulo: Márcio, a Vânia Pivello, também da } \\
\text { ecologia... }\end{array}$ \\
\hline C9 & $15: 13$ & Eu: Carlos Marques... \\
\hline C10 & $15: 15$ & Paulo: o Antônio Carlos Marques da zoo... \\
\hline C11 & $15: 16$ & Eu: e o Carlos Navas... \\
\hline C12 & $15: 19$ & Paulo: e o Carlos Navas da fisio. \\
\hline C13 & $15: 30$ & $\begin{array}{l}\text { Eu: É... uma outra pergunta então, já está meio que } \\
\text { respondida... se o senhor concorda que essas } \\
\text { abordagens, essas questões metacientíficas, devam } \\
\text { ocorrer em que momento... em que momento da } \\
\text { formação? }\end{array}$ \\
\hline C14 & $15: 41$ & $\begin{array}{l}\text { Paulo: Eu acho que desde o início né! Eu acho que... } \\
\text { eu acho que sim! Sempre tem... eu acho que existe } \\
\text { dentro da academia uma pré-concepção, do meu } \\
\text { ponto de vista equivocado, que o aluno não está } \\
\text { maduro ou ele vai estar, ele sempre vai estar, nunca }\end{array}$ \\
\hline
\end{tabular}




\begin{tabular}{|l|l|l|}
\hline & $\begin{array}{l}\text { é o momento que ele está e eu penso que é agora. } \\
\text { Agente tem muito pouco tempo, quer dizer, quatro } \\
\text { anos parece que é muito tempo, no caso do aluno } \\
\text { integral, para formar um profissional. Mas se você } \\
\text { pensar que cada disciplina capacita uma } \\
\text { determinada área, determinadas questões, vamos } \\
\text { chamar assim né, cada disciplina tem dezesseis } \\
\text { encontros para profissionalizar, de certa maneira, } \\
\text { esses indivíduos. Então não adianta ficar pensando } \\
\text { não vou trabalhar isso agora que depois ele vai ver. } \\
\text { Eu acho que é uma questão de já expor bem cedo } \\
\text { para que eles possam, como eu falei, já partir de } \\
\text { certo patamar. O que vai acontecer depois é que eles } \\
\text { vão amadurecer, vão... vão... pode ser que num } \\
\text { primeiro momento eles criem uma imagem nublada, } \\
\text { um pouco mais míope das questões mas, pelo } \\
\text { menos, eles estão enxergando alguma coisa né. } \\
\text { Acho que se trata é... é que o pessoal vê de uma } \\
\text { forma muito infantilizada... no sentido de achar aquilo } \\
\text { paternalisticamente, nunca estão preparados, agente } \\
\text { sempre vai ter que conduzir, preparar, bem a coisa } \\
\text { de docente, do condutor, no sentido negativo da } \\
\text { palavra. Eu acho que não! Tem que expor! Por } \\
\text { menos que... que compreendam já é um ganho. }\end{array}$ \\
\hline C16 & $\begin{array}{l}\text { Eu: Com certeza! Se o senhor conseguir lembrar... o } \\
\text { senhor já falou do trabalho que eles fazem } \\
\text { comparando as teoria atuais. Algum desses } \\
\text { aspectos, em algum momento específico do curso, } \\
\text { que o senhor tenha lembrando, alguma prática que } \\
\text { vocês elaboram durante o curso... trabalham também } \\
\text { aspectos mais amplos de forma explícita? }\end{array}$ \\
\hline $17: 07$ & $\begin{array}{l}\text { Paulo: Então, tem vários momentos que eu poderia, } \\
\text { talvez, destacar um pouquinho para você. Vou falar } \\
\text { alguns que são mais marcantes para mim ou que eu } \\
\text { me lembre mais, que vem de pronto. Um que é } \\
\text { uma... uma atividade que os alunos gostam muito, } \\
\text { que é feita logo no início, que é justamente essa } \\
\text { questão de eles verem como que os conceitos são } \\
\text { heterogênios na concepção deles. Então agente } \\
\text { pega o conceito de evolução, que supostamente é } \\
\text { um conceito... que é um conceito norteador da } \\
\text { biologia e que supostamente eles sabem porque está }\end{array}$ \\
\hline 179
\end{tabular}




\begin{tabular}{|c|c|c|}
\hline & & $\begin{array}{l}\text { no vestibular para biologia, evolução a... enfim. Ai } \\
\text { agente vai, expõe à classe as questões de sim e não, } \\
\text { onde eles têm individualmente que responder o } \\
\text { conhecimento dos outros né. Então, por exemplo, a } \\
\text { evolução ocorre... um exemplo de uma questão que } \\
\text { tinha lá... a seleção natural é o único fator que } \\
\text { promove a evolução, por exemplo. Então, sim ou } \\
\text { não! Ai eles pensam para si próprios, ai agente divide } \\
\text { a classe entre o sim daquele e os não daquele. } \\
\text { Assim, agente vai expondo uma sequência de seis } \\
\text { ou sete questões. Acho que são cinco perguntas, de } \\
\text { uma maneira que vai pulverizando. Até que chega } \\
\text { um momento que agente tem a classe todinha } \\
\text { dividida espacialmente, pelas respostas. Eles } \\
\text { começam a se enxergar, a classe todinha } \\
\text { pulverizada, em assuntos que inicialmente para eles } \\
\text { era uma coisa que era dada como conhecido e } \\
\text { aprendido. Ainda mais um conceito que é tão inicial } \\
\text { né. Outra questão que eu acho legal é a viagem de } \\
\text { campo, onde agente discute com eles a história da } \\
\text { elaboração de um projeto científico. Então eles vão } \\
\text { para lá, num primeiro momento que eles conhecem a } \\
\text { área e ai eles desenvolvem, bolam e desenvolvem } \\
\text { um projeto de investigação científica do começo ao } \\
\text { fim, desde a proposta até a execução, tomada de } \\
\text { dados e depois processamento de dados. A } \\
\text { divulgação desses dados em forma de um simpósio. } \\
\text { Então acho que esse é o momento que eles } \\
\text { experimentam de forma mais direta a coisa do fazer } \\
\text { ciência. Tem uma outra atividade que é uma } \\
\text { simulação de uma audiência pública que a atitude } \\
\text { que agente quer trabalhar e desenvolver é a } \\
\text { argumentação, a capacidade de argumentar e contra } \\
\text { argumentar diante das diferentes vozes, a voz da } \\
\text { política, a voz da sociedade a favor de determinado } \\
\text { processo, a voz dos especialistas, que são os } \\
\text { biólogos. Tem um outro que é um caso legal... }\end{array}$ \\
\hline C17 & $21: 20$ & Eu: Em cima de um tópico específico? \\
\hline C18 & $21: 22$ & $\begin{array}{l}\text { Paulo: Sim! Agente sempre parte de um caso real } \\
\text { que esteja em pauta na mídia naquele ano. }\end{array}$ \\
\hline C19 & $21: 28$ & Eu: E no ano passado, o senhor lembra? \\
\hline
\end{tabular}




\begin{tabular}{|c|c|c|}
\hline C20 & $21: 30$ & 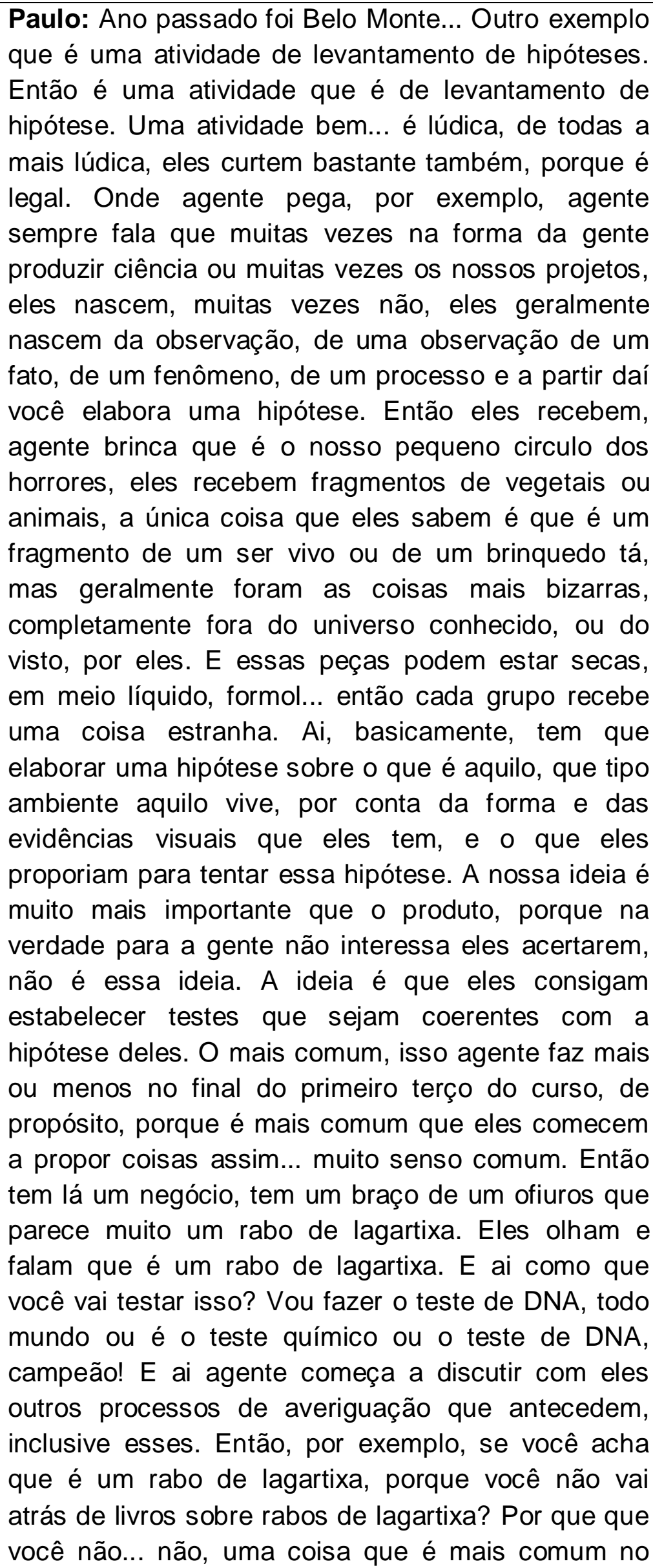 \\
\hline
\end{tabular}




\begin{tabular}{|l|l|l|}
\hline nosso meio, porque você não contata um especialista \\
em lagartixas e fala: isso é um pedaço de lagartixa? \\
Por que você não vai num museu, se você tá \\
trabalhando num museu ou numa universidade que \\
tem uma coleção de referência, por que você não vai \\
na coleção de referência e olha se as lagartixas tem \\
o rabo desse jeito, não é? Então eles começam a \\
propor uma coisa que vai muito no nível do micro \\
sem ante ir... até que ponto por exemplo um teste de \\
DNA vai te dar... vai ser informativo para te informar \\
sobre todas essas coisas que você quer saber \\
sobre... entendeu? Por que eles começam a levantar \\
pautas de onde veio, por que... como perdeu aquilo, \\
como ganhou aquilo... o que o teste de DNA... então \\
assim, dessas coisas o que vai te informar mais, ou \\
quais são as combinações de elementos que vão te \\
informar mais, então é basicamente para dar esse \\
choque!
\end{tabular}




\begin{tabular}{|c|}
\hline 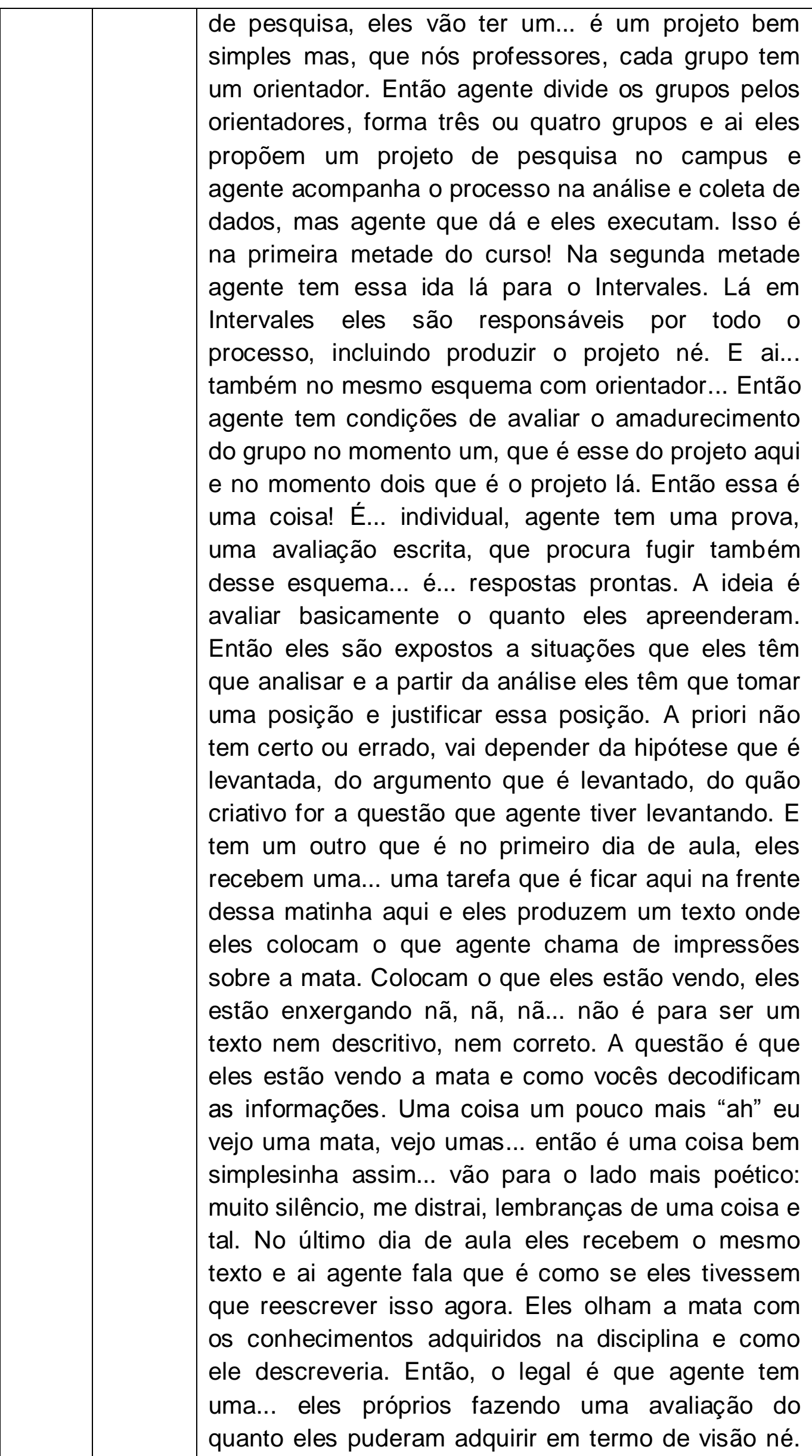 \\
\hline
\end{tabular}




\begin{tabular}{|l|l|l|}
\hline & & $\begin{array}{l}\text { E para agente também é legal porque tem essa } \\
\text { evolução nos dois tempos, é bem legal! }\end{array}$ \\
\hline C23 & $30: 10$ & $\begin{array}{l}\text { Eu: É legal! E a observação muda né! Que é um dos } \\
\text { elementos da Natureza da Ciência, que a observação } \\
\text { depende de "n" fatores. Basicamente é isso! }\end{array}$ \\
\hline
\end{tabular}

Transcrição da entrevista com o professor Dr. Carlos Ribeiro Vilela

\begin{tabular}{|c|c|c|}
\hline Turno & Tempo & Fala \\
\hline D1 & 00:00 & $\begin{array}{l}\text { Eu: Então primeiro, professor, queria que o senhor } \\
\text { discutisse brevemente sobre o chamado ensino } \\
\text { contextual de ciências. O que seria isso? Entre outros } \\
\text { pesquisadores na área de educação, um dos meus } \\
\text { referencias que é o Norman Lederman, propõe que o } \\
\text { ensino contextual seja feito por meio de abordagens, } \\
\text { em sala de aula, de questões metacientíficas. } \\
\text { Questões que trabalhem sobre a ciência. Não só } \\
\text { aprender os conceitos, mas também trabalhar como a } \\
\text { ciência se desenvolve, as questões sociais que } \\
\text { influenciam a ciência, as controvérsias científicas... } \\
\text { entre outros aspectos.... questões religiosas, } \\
\text { questões políticas, a definição de conceitos, a } \\
\text { diferença de conceitos de uma área para outra. } \\
\text { Certo? Então eu queria saber se o senhor concorda } \\
\text { que a abordagem dessas questões metacientíficas } \\
\text { seja importante para a formação do biólogo ou uma } \\
\text { pessoa que esteja em formação. }\end{array}$ \\
\hline D2 & $02: 49$ & $\begin{array}{l}\text { Carlos: Sem dúvida eu acho que... bom você acho } \\
\text { que assistiu as aulas }\end{array}$ \\
\hline D3 & 02:55 & Eu: Assisti algumas. \\
\hline D4 & 02:57 & $\begin{array}{l}\text { Carlos: Então. O principio norteador da nossa } \\
\text { disciplina é a construção do conhecimento científico } \\
\text { né, que é o projeto do Moore, Science as a Way of } \\
\text { Knowing, agente analisa a parte de genética é } \\
\text { literalmente aquele texto traduzido. Nós, quando } \\
\text { adotamos esse texto em } 1995 \text {, então já tem } 16 \text { anos, } \\
\text { foi uma época de mudança curricular, que... então, } \\
\text { nós tínhamos alunos desde o primeiro até o último } \\
\text { ano. Entraram em diferentes anos né! E ai nós }\end{array}$ \\
\hline
\end{tabular}




\begin{tabular}{|l|l|}
\hline & $\begin{array}{l}\text { éramos nove professores na disciplina. Eram cerca de } \\
250 \text { alunos matriculados. Então esse texto foi } \\
\text { trabalhado durante esses primeiros anos, por esses } \\
\text { professores e depois foi sendo reduzida... } \\
\text { Ai começou o curso de Biologia Molecular que a } \\
\text { nossa ideia é... que historicamente ele veio após a } \\
\text { Genética clássica, então ele ficaria posicionado } \\
\text { melhor depois do curso de genética básica. Então } \\
\text { esses professores fizeram parte dessa equipe né, no } \\
\text { currículo novo, pra fazer a continuidade... Se bem que } \\
\text { acabou... Como você separa a disciplina cada um } \\
\text { segue seu... e aquela ideia inicial de dar uma } \\
\text { continuidade não vingou. Mas agente continua } \\
\text { acreditando, que mais do que você dar a informação, } \\
\text { é você justamente mostrar os dramas da evolução da } \\
\text { ciência. Que... por mais que você ache que a ciência } \\
\text { tem que ser desvinculada de dogmas, as pessoas } \\
\text { sempre acabam culturalmente procurando esses } \\
\text { dogmas e sem perceber ficam dogmáticas. Então a } \\
\text { nossa ideia é essa, mostrar para os alunos a } \\
\text { evolução do conhecimento científico. Não sei bem se } \\
\text { é dentro dessa proposta, desse autor que você cita. } \\
\text { Eu: O autor, só para situar, não tem uma proposta de } \\
\text { métodos de ensino. O que ele propõe é que ensinar } \\
\text { alguns aspectos da Natureza da Ciência, alguns } \\
\text { aspectos que envolvam a ciência, sejam } \\
\text { interessantes para o ensino. Então, uma melhor } \\
\text { compreensão da ciência, para tornar um aluno e } \\
\text { futuro pesquisador, professor, mais capacitado e } \\
\text { interado do que está acontecendo. Então, ele elenca } \\
\text { alguns aspectos, que são numerosos, e há } \\
\text { controvérsias, que podem ser importantes ou não } \\
\text { para o ensino. Então ele elenca alguns que seriam } \\
\text { interessantes para serem utilizados no ensino, como: } \\
\text { que o aluno compreenda a diferença entre } \\
\text { observação e inferência, que o aluno compreenda... } \\
\text { que tenha ideia da diferença entre leis e teorias, que } \\
\text { elas... teorias não se transformam em leis, que não há } \\
\text { uma hierarquia entre essas formas de conhecimento, } \\
\text { que o aluno compreenda a influência sócio-cultural, } \\
\text { que... que faz parte da ciência, que a ciência não é } \\
\text { objetiva, que ela tá em desenvolvimento. }\end{array}$ \\
\hline $05: 18$
\end{tabular}




\begin{tabular}{|c|c|c|}
\hline & & $\begin{array}{l}\text { E, a nossa pesquisa, minha e da Maria Elice, foi } \\
\text { baseada... nós pensamos nesses alunos justamente } \\
\text { pelo livro e pelo método que vocês usam na } \\
\text { disciplina. O livro do Moore, que eu li também, e que } \\
\text { trás... }\end{array}$ \\
\hline D6 & $06: 51$ & $\begin{array}{l}\text { Carlos: Um resgate né, da evolução da genética } \\
\text { clássica, básica. }\end{array}$ \\
\hline D7 & 06:59 & Eu: É... e que é o conteúdo da disciplina. \\
\hline D8 & 07:04 & $\begin{array}{l}\text { Carlos: É! As vezes os alunos ficam um pouco } \\
\text { decepcionados com esse método, né. Porque eles } \\
\text { tem uma ânsia da novidade do conhecimento. E para } \\
\text { gente o que importa é a construção do conhecimento. } \\
\text { Mostrar como o conhecimento foi construído né, e os } \\
\text { dramas que vão surgindo a medida que o } \\
\text { conhecimento vai construindo. Que você tem } \\
\text { mudanças de paradigma né, durante a evolução do } \\
\text { conhecimento. Então todo esse enfoque é importante, } \\
\text { ele não é o fim, mas é um meio que agente usa para } \\
\text { ensinar genética. }\end{array}$ \\
\hline D9 & 07:47 & $\begin{array}{l}\text { Eu: } \mathrm{O} \text { senhor disse que os alunos ficam } \\
\text { decepcionados? Como assim? Algum momento? }\end{array}$ \\
\hline D10 & 07:54 & $\begin{array}{l}\text { Carlos: A ideia que você tem, como você tá tratando } \\
\text { conceitos já sedimentados, embora não, na nossa } \\
\text { opinião, adequados. Porque o vestibular, infelizmente, } \\
\text { ele desvirtua todo o ensino, tanto o ensino da } \\
\text { universidade quanto do ensino médio, fundamental, } \\
\text { né. Por que? Porque você tem que encontrar uma } \\
\text { maneira de selecionar pessoas, então essa multidão } \\
\text { que você tem, de } 125 \text { mil alunos que a FUVEST } \\
\text { seleciona para } 10 \text { mil vagas, você tem que ter algum } \\
\text { critério. Inevitavelmente por mais que você faça ã... } \\
\text { questões interdisciplinares, você acaba exigindo } \\
\text { conhecimento e esse conhecimento eles tem ideia } \\
\text { que já tá pronto. Aquela história das verdades } \\
\text { científicas que agente batalha desde o começo. } \\
\text { Porque se existe verdade científica ela se torna um } \\
\text { dogma, vira é uma religião. Então agente tem que } \\
\text { batalhar muito e é muito difícil para eles. Porque } \\
\text { quando eles fazem vestibular, o vestibular você tem } \\
\text { uma pergunta certa e uma pergunta errada. Quando }\end{array}$ \\
\hline
\end{tabular}




\begin{tabular}{|c|c|c|}
\hline & & $\begin{array}{l}\text { agente discute que é tudo relativo então é um pouco } \\
\text { de choque pros próprios alunos. Então eles levantam, } \\
\text { simplificadamente, então tudo que aprendemos está } \\
\text { errado. Não! Não é assim. Vamos verificar como é } \\
\text { que vocês aprenderam e vamos olhar por outro } \\
\text { ângulo. }\end{array}$ \\
\hline D11 & 09:28 & Eu: De forma mais crítica talvez, né. \\
\hline D12 & 09:30 & $\begin{array}{l}\text { Carlos: Então é muito difícil e eles... porque agente, } \\
\text { por exemplo, não tem gabaritos para as questões que } \\
\text { agente apresenta, entende. E eles tem essa ânsia, } \\
\text { essa necessidade, esse referencial de gabarito, de } \\
\text { verdade. Então agente deixa solto e eles ficam um } \\
\text { pouco perdidos. Nem todos conseguem compreender } \\
\text { o que agente quer passar para eles, né. É muito } \\
\text { pouco! Acho que seria necessário que mais } \\
\text { disciplinas, ao longo da formação do aluno, tivesse } \\
\text { esse mesmo enfoque, acho! Porque a maioria tá } \\
\text { preocupada em mostrar as novidades do } \\
\text { conhecimento, que é exponencial e é impossível você } \\
\text { passar para o aluno na nossa formação. }\end{array}$ \\
\hline D13 & $10: 21$ & $\begin{array}{l}\text { Eu: Só para... o senhor, com certeza tem mais } \\
\text { contato do que eu. Conversando com os professores } \\
\text { e olhando a ementa das disciplinas, só do primeiro } \\
\text { período, que é o meu foco... eu achei... Eu não me } \\
\text { formei aqui na USP e eu achei bastante interessante } \\
\text { essa preocupação em outras disciplinas também. Não } \\
\text { com o enfoque histórico talvez, mas com o enfoque } \\
\text { metacientífico, trazendo questões... aqui tem } \\
\text { Antropologia da Ciência também, dada pelo Rui, } \\
\text { Filosofia das Ciências Biológicas também pelo Rui, ou } \\
\text { o professor Paulo Sano com a disciplina Fauna, Flora } \\
\text { e Ambiente traz bastante coisa. Eu já achei bastante } \\
\text { coisa, talvez precisasse de mais... mas eu já achei, já, } \\
\text { já... }\end{array}$ \\
\hline D14 & $11: 26$ & $\begin{array}{l}\text { Carlos: É, os alunos tão fazendo uma reavaliação } \\
\text { desse currículo. Vai ter uma reunião essa semana } \\
\text { acho, teve uma semana passada. Porque eles } \\
\text { fizeram um levantamento né, uns questionários para } \\
\text { os professores e para os alunos. Nem todos } \\
\text { responderam. Eu inclusive não respondi porque } \\
\text { passou numa época imprópria de fim de semestre. }\end{array}$ \\
\hline
\end{tabular}




\begin{tabular}{|l|l|l|}
\hline | & $\begin{array}{l}\text { Então eles fizeram uma tabulação e acho que eles } \\
\text { devem ter dados interessantes. Porque eles } \\
\text { representam a parte interessada ai né, que são os } \\
\text { profissionais que estão sendo formados. Como eles } \\
\text { veem o currículo novo. Eu particularmente não sou } \\
\text { muito favorável a esse currículo. Desde o início né, eu } \\
\text { ã... tinha uma outra ideia curricular na época mas, } \\
\text { seguindo as normas do MEC, outras... outros pré- } \\
\text { requisitos, acabou sendo adotado e eu sinto que } \\
\text { ainda continua o que eu chamo de colcha de retalhos } \\
\text { curricular. Eu não consigo ver uma ligação tanto } \\
\text { horizontal quanto vertical da disciplina. Eu acho, } \\
\text { olha... vários temas que estão sendo contemplados } \\
\text { mas, não basta isso, você tem que ter uma integração } \\
\text { das coisas. }\end{array}$ \\
\hline D15 & $12: 47$ & \begin{tabular}{l} 
Eu: Ainda mais na biologia (risos) \\
\hline D16
\end{tabular} \\
\hline $12: 51$ & $\begin{array}{l}\text { Carlos: Então eu não vejo isso como um currículo } \\
\text { adequado. Aliás, eu não vejo nem muita diferença } \\
\text { entre o currículo que eu fiz aqui na universidade... eu } \\
\text { me formei em 1961 e o que tem hoje? Não consigo } \\
\text { ver diferença! Acrescentou mais disciplinas, mas eu } \\
\text { continuo achando que tá faltando integração. Eu não } \\
\text { consigo ver possibilidade dessa integração. Desde } \\
\text { dos... as reuniões para elaborar o próprio currículo } \\
\text { como a efetivação. Você veja, nós agora estamos } \\
\text { numa segunda fase, que é a fase que os primeiros } \\
\text { alunos do currículo novo, terminaram o ciclo básico e } \\
\text { estão fazendo agora o ciclo optativo e a maioria deles } \\
\text { tem que fazer disciplinas porque precisam dos } \\
\text { créditos, não porque eles estão interessados naquela } \\
\text { vertente, porque não tem opção. }\end{array}$ \\
\hline $13: 53$ & $\begin{array}{l}\text { Eu: Ok. Isso é péssimo mesmo. Eu passei por isso. } \\
\text { Carlos: Então é difícil... achar o currículo ideal e a } \\
\text { maneira de ensinar. A medida que eu vou passando } \\
\text { os anos eu cada vez estou mais convencido de que... } \\
\text { agente deveria usar sempre a metodologia } \\
\text { heurística... convencer todos os elementos da própria } \\
\text { equipe, mas eu acho que é... para mim é o melhor } \\
\text { caminho né, que é você dar chance ao aluno, dele } \\
\text { fazer a descoberta, que é um dos prazeres de você... }\end{array}$ \\
\hline $13: 58$
\end{tabular}




\begin{tabular}{|c|c|c|}
\hline & & $\begin{array}{l}\text { intelectuais, o prazer da descoberta. } \\
\text { O professor, para mim a função dele é um tutor, ele } \\
\text { só mostra o caminho para o aluno, embora o aluno } \\
\text { tenha aquela sede de querer que o professor informe } \\
\text { a ele. Hoje, com toda a disponibilidade da internet, } \\
\text { você tem tudo num apertar de botões. Quase todo o } \\
\text { conhecimento tá ali... você não precisa. Então você } \\
\text { precisa sim de uma orientação, como você seguir o } \\
\text { caminho e de alguém mostrar pra você que tem o } \\
\text { prazer da descoberta. Coisas que já são do } \\
\text { conhecimento da ciência. Não importa! Isso é } \\
\text { descoberta pra você. Cada um é um. }\end{array}$ \\
\hline D19 & 15:18 & Eu: Ensinar a pesquisar né! Ensinar a ir atrás. \\
\hline D20 & $15: 21$ & $\begin{array}{l}\text { Carlos: Traduzindo... não dar o peixe, mas ensinar o } \\
\text { aluno a pescar. Se você está dando oportunidade a } \\
\text { ele, o potencial durante a vida toda de ele se tornar } \\
\text { um bom cientista um bom professor, um cidadão em } \\
\text { si né. E eu realmente não consigo ver isso no nosso } \\
\text { currículo, infelizmente. }\end{array}$ \\
\hline D21 & $15: 41$ & Eu: Algum currículo que o senhor conheça? \\
\hline D22 & $15: 43$ & $\begin{array}{l}\text { Carlos: Não! Eu acho que todos eles, a maioria } \\
\text { deles, originalmente... eles são todos deturpados } \\
\text { devido ao vestibular. Eu acho que o vesti... claro ele } \\
\text { altera todo o currículo do ensino fundamental e da } \\
\text { própria universidade. Porque você joga aquele monte } \\
\text { de informação que não foi trabalhada } \\
\text { adequadamente, que você tem que retrabalhar aquilo. } \\
\text { É muito mais fácil você construir do nada do que fazer } \\
\text { uma reforma. O que agente faz é uma reforma da } \\
\text { cabeça das pessoas que entram na universidade. } \\
\text { Isso dá muito trabalho e tem pouco sucesso. }\end{array}$ \\
\hline D23 & $16: 30$ & $\begin{array}{l}\text { Eu: Vamos partir para a segunda questão. Essa } \\
\text { questão, mais de momentos e um pouco de currículo } \\
\text { que o senhor entrou, vamos focar um pouquinho na } \\
\text { disciplina agora. O senhor diria que essas questões } \\
\text { metacientíficas são trabalhadas ao longo da } \\
\text { disciplina. De maneira implícita ou explícita, o senhor } \\
\text { acredita? }\end{array}$ \\
\hline
\end{tabular}




\begin{tabular}{|l|l|l|}
\hline D24 17:04 & $\begin{array}{l}\text { Carlos: Eu acho que ambos! Não são mutuamente } \\
\text { exclusivos. }\end{array}$ \\
\hline D25 & $17: 11$ & $\begin{array}{l}\text { Eu: (risos) De algum momento ou alguma parte do } \\
\text { livro, ou algum período da disciplina, uma aula } \\
\text { específica, eu assisti a aula do Mariano Amabis, que } \\
\text { é a primeira que fala sobre método científico, então } \\
\text { seria bem específico, trabalham essas questões } \\
\text { sobre a ciência, sobre tudo que envolve a ciência? O } \\
\text { senhor se recorda? Ou algum momento do livro do } \\
\text { Moore que te chame atenção? }\end{array}$ \\
\hline D26 18:08 & $\begin{array}{l}\text { Carlos: Eu acho que isso tá implícito em toda obra. } \\
\text { Agente tem quinze temas e o enfoque dele é todo } \\
\text { nesse sentido, ao longo de toda obra. Agente apenas } \\
\text { acrescenta mais dois temas que ele não engloba } \\
\text { especificamente no caso da genética, que é a parte } \\
\text { de teste estatístico né, que eu acho que falta. Embora } \\
\text { eles tenham no currículo a disciplina de estatística } \\
\text { logo, paralela mesmo com essa nossa, eles tem uma } \\
\text { visão muito matemática da estatística. Agente teve } \\
\text { reunião com os professores que dão aula... Então eu } \\
\text { acho que, digerindo essa estatística que muitos têm } \\
\text { aversão, por uma pessoa que não é estatístico, que é } \\
\text { o meu caso, eu acho que facilita. } \\
\text { Eu, mais ou menos, transfiro as dificuldades que eu } \\
\text { tive quando fui aprender. Então eu acho que agente } \\
\text { ter acrescentado isso, encaixado isso, dentro do } \\
\text { sistema do Moore, com a mesma filosofia, foi um } \\
\text { avanço para o projeto. } \\
\text { E o outro é a parte de genética de populações que a } \\
\text { parte de herança quantitativa... não! É genética de } \\
\text { populações, desculpa! Que faz a ligação da genética } \\
\text { básica com a genética de populações. Então essa } \\
\text { parte também não foi contemplada, então agente } \\
\text { tenta encaixar isso dentro do contexto. } \\
\text { Embora, com a reforma curricular o projeto inicial } \\
\text { nosso ficou um pouco capenga, porque agente tinha } \\
\text { uma carga horária de oito horas por semana e ela foi } \\
\text { reduzida para quatro. Então tem disciplinas que } \\
\text { continuam com oito e que não teriam necessidade. } \\
\text { Foi uma pena! Esse curso agente estruturou para }\end{array}$ \\
\hline
\end{tabular}




\begin{tabular}{|l|l|l|}
\hline & & $\begin{array}{l}\text { uma carga de oito horas que você ficava um dia } \\
\text { inteiro com os alunos, não só meio período. Embora } \\
\text { fosse uma vez por semana eu acho que isso era } \\
\text { importante para fazer essa lavagem cerebral que eu } \\
\text { acho que é importante para quem passa pelo } \\
\text { vestibular. }\end{array}$ \\
\hline D27 & $19: 55$ & $\begin{array}{l}\text { Eu: É legal mesmo! Pensando naquilo é bem } \\
\text { interessante. }\end{array}$ \\
\hline D28 & $20: 00$ & $\begin{array}{l}\text { Carlos: Usar aquela ideia de ficar batalhando, } \\
\text { insistindo na mesma tecla né, de que as verdades } \\
\text { são temporárias, é difícil para as pessoas aceitarem. } \\
\text { Porque acho que é meio inerente do ser humano } \\
\text { você ter referenciais. Quando você diz que é relativo, } \\
\text { que é temporário, você fica sem referencial. Fica um } \\
\text { pouco perdido! }\end{array}$ \\
\hline D29 & $20: 26$ & $\begin{array}{l}\text { Eu: Tomar cuidado quando passar isso para não } \\
\text { achar que a ciência é qualquer coisa. Contra o } \\
\text { método como... alguns filósofos. Uma terceira } \\
\text { questão que eu tinha aqui. Durante as avaliações... o } \\
\text { que eu tive acesso do material da genética, foram } \\
\text { as... vocês deixaram na xerox... }\end{array}$ \\
\hline D32 & $21: 25$ & $\begin{array}{l}\text { Carlos: É uma atividade optativa. } \\
\text { Carlos: Sim! Isso é muito explorado durante o projeto } \\
\text { de pesquisa né. Que eles fazem um projeto de } \\
\text { pesquisa e fazem um simulado de manuscrito. } \\
\text { Então eu acho que, pra mim, a parte principal da } \\
\text { disciplina é a prática, mais do que a própria teoria. } \\
\text { Porque a prática vai dar a oportunidade a ele de } \\
\text { refletir, de divagar, de levantar hipótese, de propor } \\
\text { teste. Então eu acho que é a parte hã... vamos dizer } \\
\text { assim mais enriquecedora para ele. Você percebe } \\
\text { isso porque todos os alunos após se formarem, eles } \\
\text { quando retornam... porque agente tem um serviço de }\end{array}$ \\
\hline D31 & $21: 02$ & $\begin{array}{l}\text { Eu: Eu queria saber durante o processo de avaliação, } \\
\text { durante as provas, durante o projeto que eles têm na } \\
\text { aula prática... os professores se preocupam em } \\
\text { avaliar esse desenvolvimento dessa concepção de } \\
\text { aue não existe verdade ou não. É um critério de }\end{array}$ \\
\hline avão?
\end{tabular}




\begin{tabular}{|l|l|l|}
\hline | & & $\begin{array}{l}\text { orientação didática né, para ensino de genética que é } \\
\text { fundamental... eles dizem que o que ficou para eles } \\
\text { durante o curso foi o projeto de pesquisa tá. Então } \\
\text { você vê que todo o resto talvez tenha sido } \\
\text { incorporado inconscientemente, mas aquilo que } \\
\text { realmente na memória que eles vão lembrar é o } \\
\text { projeto, a realização do projeto. Então eu considero o } \\
\text { projeto a parte mais essencial da disciplina né. }\end{array}$ \\
$\begin{array}{l}\text { Talvez se agente pudesse só fazer projetos você } \\
\text { poderia usar a própria filosofia do Moore, mostrar a } \\
\text { construção do conhecimento, fazendo o próprio } \\
\text { projeto. Eu acho que seria muito mais interessante, } \\
\text { não? Mas na realidade você acaba seguindo esse } \\
\text { padrão de teoria e de prática como se fossem coisas } \\
\text { separadas. Talvez só a prática funcionasse melhor. }\end{array}$ \\
\hline D33 & $23: 21$ & $\begin{array}{l}\text { Eu: Interessante isso! Eu gostava muito das práticas } \\
\text { também. }\end{array}$ \\
\hline D34 & $23: 24$ & $\begin{array}{l}\text { Carlos: Você, a partir das práticas, se o professor } \\
\text { sabe explorar, ele tira todo esse avanço do } \\
\text { conhecimento com a própria aula prática. }\end{array}$ \\
\hline D38 & $24: 44$ & $\begin{array}{l}\text { Carlos: Então a avaliação é feita por média } \\
\text { ponderada de três notas. Eles têm duas notas e o } \\
\text { projeto. Então, a cada ano agente tem mudado o } \\
\text { peso do projeto em relação às provas. Porque por }\end{array}$ \\
\hline D36 & $23: 52$ & $\begin{array}{l}\text { Eu: Então o senhor percebe, ou percebeu, uma } \\
\text { mudança nos alunos... alguma coisa pontual talvez? } \\
\text { Carlos: É difícil porque cada turma é única, então é } \\
\text { difícil comparar anos diferentes. O que agente faz é o } \\
\text { seguinte, a própria equipe faz uma autocrítica no final } \\
\text { de cada ano e agente anota o que não funcionou e } \\
\text { agente, gradualmente, vamos mudando. Nesses vinte } \\
\text { e oito anos eu nunca repeti a mesma disciplina da } \\
\text { mesma maneira. Agente vai sempre tentando } \\
\text { encontrar caminhos para resolver problemas que não } \\
\text { nos satisfizeram durante a evolução da própria } \\
\text { disciplina. Então agente tem tentado mostrar pra eles } \\
\text { a importância do próprio projeto, mudando os pesos } \\
\text { né, durante a avaliação. Você tá falando de avaliação. }\end{array}$ \\
\hline Eu: É!
\end{tabular}




\begin{tabular}{|c|c|c|}
\hline & & $\begin{array}{l}\text { mais que agente faça provas de questionamento, de } \\
\text { mínimo possível de memória, de memorização de } \\
\text { conhecimento, apenas explorando os conceitos mais } \\
\text { básicos, importantes dentro da área, agente tem } \\
\text { procurado, proporcionalmente, aumentar o peso né, } \\
\text { do projeto em relação a essas avaliações da parte } \\
\text { teórica. } \\
\text { Agente já vai fazer uma nova mudança agora para } \\
\text { dois mil e doze, já tá quase cinquenta por cento da } \\
\text { avaliação, vai ser quarenta por cento. O problema } \\
\text { que agente vê nessa mudança é o seguinte: como a } \\
\text { parte prática é feita em grupos e a avaliação teórica é } \\
\text { individual, nós estamos vendo duas coisas ai. É difícil } \\
\text { para você dentro de um grupo, distribuir as funções } \\
\text { que cada elemento do grupo... é importante na } \\
\text { formação dele né, como aprender a trabalhar em } \\
\text { grupo, mas você avaliar individualmente dentro de um } \\
\text { grupo é muito difícil, então você acaba avaliando o } \\
\text { grupo como um todo. E ai o que agente tenta evitar é } \\
\text { você dar um peso maior para que um aluno se } \\
\text { aproveite do grupo para ter uma boa avaliação sem } \\
\text { ter feito nada. }\end{array}$ \\
\hline D39 & $26: 24$ & Eu: Isso acontece! \\
\hline D40 & $26: 27$ & $\begin{array}{l}\text { Carlos: É! Então por isso que agente tem evitado } \\
\text { colocar um peso maior na atividade do projeto em } \\
\text { relação à teórica. Numa relação custo benefício da } \\
\text { formação do aluno. Como trabalhar em grupos etc. O } \\
\text { problema é como avaliar isso, né! Você acaba } \\
\text { avaliando o grupo e, na realidade, as vezes, a } \\
\text { contribuição dos elementos do grupo não foi a mesma } \\
\text { para aquele resultado. }\end{array}$ \\
\hline D41 & $26: 59$ & $\begin{array}{l}\text { Eu: Isso é complicado mesmo! Basicamente é isso } \\
\text { professor. A última pergunta que eu tenho, não é nem } \\
\text { uma pergunta. Se o senhor quiser perguntar alguma } \\
\text { coisa sobre os meus objetivos, sobre o meu trabalho } \\
\text { ou comentar alguma coisa que o senhor ache } \\
\text { interessante, que tenha acontecido ou que acontece } \\
\text { na disciplina e que eu não perguntei aqui. }\end{array}$ \\
\hline D42 & $27: 20$ & $\begin{array}{l}\text { Carlos: Então, quais as disciplinas que você } \\
\text { analisou? }\end{array}$ \\
\hline
\end{tabular}




\begin{tabular}{|l|l|l|}
\hline D43 & $27: 24$ & Eu: Então! \\
\hline D44 & $27: 25$ & Carlos: Do currículo. \\
\hline D45 & $27: 26$ & $\begin{array}{l}\text { Eu: O meu foco não são as disciplinas, o meu foco } \\
\text { são os alunos. O que eu queria ver nas disciplinas? } \\
\text { Com a ementa das disciplinas, se elas traziam, só na } \\
\text { ementa, nem investigar se os professores aplicaram } \\
\text { ou não isso, alguns tópicos que pudessem trabalhar } \\
\text { questões desse tipo, de natureza da ciência, de } \\
\text { questões metacientíficas, seja lá qual for o nome que } \\
\text { queiram dar. E eu encontrei vários tópicos! A } \\
\text { disciplina de Genética eu já conhecia o livro do } \\
\text { Moore, a disciplina de Filosofia, Antropologia trazem } \\
\text { muito isso, a de Fauna, Flora e Ambiente, alguns } \\
\text { pontos daquela ementa, poderiam ser trabalhados ou } \\
\text { enaltecidos durante aquela aula, essas questões, que } \\
\text { a ciência não é verdade, questões sociais, etc. } \\
\text { Com essa proposta de fazer a entrevista, foi proposta } \\
\text { dada pelo professor Rui Murieta, durante a minha } \\
\text { qualificação ele falou: Faça uma entrevista com os } \\
\text { professores. São dados interessantes também, que } \\
\text { eles vão te dar outra fonte de dados para investigar } \\
\text { as possíveis mudanças nas concepções dos alunos. } \\
\text { Eu fiz a pesquisa com eles no início do primeiro } \\
\text { semestre e no final do primeiro semestre. Ai eu } \\
\text { comecei a fazer as entrevistas. Na genética fiz com o } \\
\text { professor Luis também, fiz com o professor Paulo } \\
\text { Sano de Fauna, Flora e Ambiente, com a professora } \\
\text { Mariana de Diversidade, professora Mariana Oliveira } \\
\text { da Botânica. E... o que eu estou vendo de vocês } \\
\text { professores é que há uma preocupação, coisas que } \\
\text { as vezes, não sei, eu acho que não teria essa } \\
\text { preocupação... pelo menos um início de preocupação } \\
\text { de trabalhar esse conceito mais amplo da ciência e } \\
\text { não só trabalhar, com os alunos, os conceitos } \\
\text { entendeu. E isso que eu estou achando bastante } \\
\text { interessante. } \\
\text { Geralmente abordagens semelhantes à que eu estou } \\
\text { fazendo na minha pesquisa de mestrado fazem o } \\
\text { seguinte: aplicam algum questionário, fazem alguma } \\
\text { entrevista, algum método de avaliação das } \\
\text { concepções dos alunos, praticam algum curso, }\end{array}$ \\
\hline
\end{tabular}




\begin{tabular}{|l|l|}
\hline & $\begin{array}{l}\text { geralmente de história da ciência, história da biologia, } \\
\text { física ou o que seja, durante um período limitado, uma } \\
\text { semana as vezes, e querem ver uma resposta logo no } \\
\text { final do curso. Julgando que uma abordagem explícita } \\
\text { desse conteúdo possa favorecer e tal. Mas há vários } \\
\text { problemas. Será que o que ele aprendeu aqui, que } \\
\text { ele está aqui logo depois do curso, daqui a duas } \\
\text { semanas um mês ele esteja, é... vários problemas. } \\
\text { E a minha intenção era não estar influenciando esses } \\
\text { alunos, ou talvez os professores, se eu estivesse em } \\
\text { todas as aulas. Algum professor, numa conversa } \\
\text { maior queria poder agradar... sei lá... um vínculo ali, } \\
\text { ele sabe que eu estou pesquisando, sabe o que eu } \\
\text { quero encontrar. E agora eu estou investigando as } \\
\text { disciplinas e vendo essa preocupação dos } \\
\text { professores e eu estou achando muito interessante. } \\
\text { Eu achei que eu pudesse não encontrar essa } \\
\text { preocupação tão clara dos professores, entendeu. }\end{array}$ \\
\hline
\end{tabular}

Transcrição da entrevista com o professor Dr. Rui Sergio Sereni Murrieta

\begin{tabular}{|c|c|c|}
\hline Turno & Tempo & Fala \\
\hline E1 & 00:00 & $\begin{array}{l}\text { Eu: Tudo que o senhor lembrar e tudo mais e falar } \\
\text { sobre eu queria que o senhor remetesse às } \\
\text { disciplinas, tanto a de Filosofia das Ciências } \\
\text { Biológicas que, acredito eu seja a que trabalhou mais } \\
\text { o que eu quero investigar e a de Antropologia, que eu } \\
\text { conheço menos na realidade. }\end{array}$ \\
\hline E2 & $00: 22$ & Rui: Se você quiser eu te passo $0 . .$. \\
\hline E3 & 00:24 & $\begin{array}{l}\text { Eu: Eu estou com a ementa aqui só. Eu já tinha já... } \\
\text { mas nas questões de Natureza da Ciência acho que } \\
\text { a disciplina de Filosofia talvez... }\end{array}$ \\
\hline E4 & $00: 36$ & $\begin{array}{l}\text { Rui: Sim, eu acho que agente discute em } \\
\text { Antropologia, mas Filosofia ataque de uma forma } \\
\text { mais persistente? }\end{array}$ \\
\hline E5 & $00: 46$ & Eu: Explícito também, talvez? \\
\hline E6 & $00: 47$ & $\begin{array}{l}\text { Rui: Sim! É uma discussão que é bem orientada para } \\
\text { isso. Principalmente a primeira parte... a segunda }\end{array}$ \\
\hline
\end{tabular}




\begin{tabular}{|c|c|c|}
\hline & & $\begin{array}{l}\text { parte também, mas a primeira parte onde você da } \\
\text { um... faz uma tomada geral do... cenário, } \\
\text { principalmente pré-moderno... e moderno, falando de } \\
\text { empirismo e racionalismo. Depois o... a... eu fazia } \\
\text { isso agora o... }\end{array}$ \\
\hline E7 & $01: 16$ & Eu: O Hamilton que tá com essa disciplina? \\
\hline E8 & $01: 17$ & $\begin{array}{l}\text { Rui: Ele tá na segunda metade. Que é exatamente } \\
\text { onde ele foca na Biologia, em aspectos éticos. Uma } \\
\text { das coisas que não existem, talvez no seu programa, } \\
\text { foi uma novidade dos últimos dois anos, que é o foco, } \\
\text { duas aulas que nós temos, sobre ética, que foi uma } \\
\text { demanda dos alunos. Os alunos tinham esse } \\
\text { problema na cabeça e achavam interessante ter, pelo } \\
\text { menos uma aula sobre ética e... ética na biologia } \\
\text { especificamente. }\end{array}$ \\
\hline E9 & 02:01 & $\begin{array}{l}\text { Eu: Entendi! Como a maioria dos outros professores } \\
\text { não trabalhavam diretamente sobre essas questões } \\
\text { metacientíficas no ensino, as minhas perguntas eram } \\
\text { geralmente de querer buscar deles é... e apresentar } \\
\text { um pouco para eles essas questões, as vezes e } \\
\text { tentar buscar se eles aplicavam, de certa forma, ou } \\
\text { de forma implíita ou explícita, nas aulas deles essa } \\
\text { discussão. Para o senhor já não... para você já é } \\
\text { outro argumento. O que você acha da inclusão } \\
\text { dessas discussões metacientíficas no ensino. }\end{array}$ \\
\hline E10 & $02: 49$ & $\begin{array}{l}\text { Rui: Eu acho essenciais. Um dos grandes problemas } \\
\text { da academia atualmente é que existe uma enorme } \\
\text { orientação para formar para técnica e especializada e } \\
\text { existe muito pouca discussão de caráter } \\
\text { epistemológico. De caráter filosófico, mas com foco } \\
\text { em aspectos epistemológicos! Isso é um problema } \\
\text { porque na verdade é... você só consegue formar } \\
\text { cientistas no momento em que o cientista sabe o seu } \\
\text { papel e que ele entende que a produção do } \\
\text { conhecimento, do conhecimento e não de } \\
\text { informação. Você pode falar de tudo e produzir } \\
\text { informação e isso qualquer técnico de laboratório faz. } \\
\text { Agora produção de conhecimento ela implica numa } \\
\text { produção mais profunda e maior, não só sobre o que } \\
\text { é ser um cientista, formação de um cientista, como } \\
\text { deve ser a formação de um cientista, ele entender }\end{array}$ \\
\hline
\end{tabular}




\begin{tabular}{|l|l|l|}
\hline que está trabalhando com o conhecimento, não só \\
com informação e também com a repercussão maior \\
do papel dele na sociedade e na história. Sem isso \\
você não forma cientistas, você forma técnicos \\
glorificados. Eles podem ter doutorado e tudo, mas \\
eles não se comportam e não praticam a ciência no \\
seu sentido mais amplo. Isso eu acho que é um \\
perigo que a gente já... perigo eu acho uma palavra \\
forte, mas um problema que a gente já identificou a \\
alguns anos que é a ideia de incluir no currículo \\
básico Filosofia das Ciências Biológicas com \\
professores voltados pros problemas da biologia ou \\
pelo menos de ciências que são tributárias da \\
biologia, tornou uma preocupação constante e isso \\
que foi o que deu impulso à criação da disciplina. E a \\
mesma coisa de Antropologia, porque a biologia ela \\
tá ocupando o papel que era das ciências sociais, de \\
fazer a cola interdisciplinar. Esse papel foi um papel \\
que todos esperavam que seria das ciências sociais \\
e políticas, mas não aconteceu. Ao contrário houve \\
um movimento de distanciamento das ciências \\
naturais e agora, esse papel que todo mundo achava \\
que se acomodaria nas grandes agências sociais, \\
simplesmente não aconteceu. E parece que, de uma \\
forma quase que espontânea, a biologia e nas suas \\
áreas mais fronteiriças abarcou essa tarefa. Então, \\
hoje em dia, o biólogo precisa ter essa formação. \\
Mesmo que ele não se torne um cientista, mas ele \\
precisa ter para se engajar num debate mais amplo. \\
Um dos problemas que agente percebeu na geração, \\
na sua geração principalmente, era a falta de \\
articulação tanto filosófica quanto no aspecto básico \\
de realmente é... conhecimentos do jargão, \\
engajamento do discurso, que era quase que \\
absoluta na geração de vocês. Você não conseguia, \\
por mais inteligente que fossem os alunos, mais \\
interessados que eles fossem que eles se \\
engajassem de uma forma minimamente sofisticada \\
no debate.
\end{tabular}




\begin{tabular}{|c|c|c|}
\hline & & USP? \\
\hline E12 & 07:24 & $\begin{array}{l}\text { Rui: Cinco anos! As duas começaram comigo. Na } \\
\text { verdade a disciplinas de Filosofia da Ciência } \\
\text { começou com a iniciativa do professor Gilberto Xavier } \\
\text { e eu fazia parte do time interunidades. Todo o debate } \\
\text { da disciplina precisava ser retirado das ciências } \\
\text { sociais, porque eles tinham um viés que não } \\
\text { contemplava a discussão interna da biologia. A crítica } \\
\text { era sempre externa e isso criava uma certa... um } \\
\text { certo distanciamento e uma certa... até uma certa } \\
\text { repulsa... }\end{array}$ \\
\hline E13 & 08:06 & Eu: ...dos alunos. \\
\hline E14 & 08:06 & $\begin{array}{l}\text { Rui: ... por conta disso, porque realmente não havia } \\
\text { nenhum ponto de intersessão. Ai nós trouxemos para } \\
\text { cá e direcionamos... eu insisti muito no aspecto da } \\
\text { metodologia da ciência, porque eu achava } \\
\text { escandaloso o fato de que a maioria dos alunos } \\
\text { tinham uma visão da ciência que era confusa da } \\
\text { prática científica... e dos aspectos, principalmente } \\
\text { metodológicos, que era confusa e, na verdade } \\
\text { completamente superficial. No fundo eles repetiam os } \\
\text { procedimentos técnicos sem saber os elementos } \\
\text { básicos da parte metodológica. Não é o método em si } \\
\text { na prática laboratorial, de campo, mas o debate } \\
\text { metodológico, o debate mais amplo dos elementos } \\
\text { conceituais, das unidades de análise... }\end{array}$ \\
\hline E15 & 09:04 & Eu: que levou ao desenvolvimento do método. \\
\hline E16 & 09:05 & $\begin{array}{l}\text { Rui: Exato! } \mathrm{E} \text { principalmente nessas áreas de } \\
\text { interação com outras disciplinas. Ai a coisa, } \\
\text { realmente, ficava muito complicada e você está } \\
\text { sentindo isso na pele. }\end{array}$ \\
\hline E17 & 09:20 & $\begin{array}{l}\text { Eu: (risos) Um pouquinho. Então vamos... eu queria, } \\
\text { agora, focar mais nessa questão dos aspectos da } \\
\text { natureza da Ciência que eu busquei investigar um } \\
\text { pouco, dos alunos, com base no Norman Lederman, } \\
\text { que é um dos especialistas na área, que ele descreve } \\
\text { sete aspectos da Natureza da Ciência né... do } \\
\text { trabalho científico e tudo mais, a serem trabalhados } \\
\text { no ensino. E esses aspectos seriam importantes para } \\
\text { serem trabalhados no ensino. Como eu não sei se o }\end{array}$ \\
\hline
\end{tabular}




\begin{tabular}{|l|l|l|}
\hline E18 & $10: 07$ & $\begin{array}{l}\text { senhor já viu. } \\
\text { Rui: Não eu, não... }\end{array}$ \\
\hline E19 & $10: 08$ & $\begin{array}{l}\text { Eu: ... eu queria que... passasse o olho, pelo menos, } \\
\text { tivesse um conhecimento para eu saber um pouco } \\
\text { mais sobre. }\end{array}$ \\
\hline $10: 18$ & $\begin{array}{l}\text { Rui: é são todos aqui, todos esses pontos são } \\
\text { abordados, de uma forma ou de outra, na... uma } \\
\text { aspecto que é absolutamente fundamental é o... da } \\
\text { observação e inferência obviamente e ai implica em } \\
\text { você inclusive entender o que é... entender } \\
\text { fundamentos lógicos que tem que fazer parte do } \\
\text { conhecimento científico, que as pessoas e } \\
\text { principalmente um aluno que chega do ensino } \\
\text { público, ou mesmo que tenha acesso às melhores } \\
\text { escolas, ele não consegue identificar as diferenças } \\
\text { básicas entre dedução e indução e quando consegue } \\
\text { são equivocados porque ele tá articulado a uma série } \\
\text { de deixas que ele usou para entender ou para } \\
\text { memorizar essas diferenças. Então... isso é um dos } \\
\text { problemas básicos que eu fiz questão de abordar na } \\
\text { filosofia. Porque para mim era muito estranho você } \\
\text { conversar com um aluno, já que tava na pós- } \\
\text { graduação e ele não saber a diferença entre isso e } \\
\text { não saber se ele...ele tinha uma prática ou ele tinha } \\
\text { uma reflexão indutiva ou dedutiva. Por mais que o } \\
\text { método na Biologia tenda a uma certa mistura ou } \\
\text { uma certa combinação, não existia essa } \\
\text { diferenciação básica, não existia um conhecimento } \\
\text { minimamente sofisticado sobre teste de hipóteses é... } \\
\text { no método hipotético-dedutivo. Existia uma visão } \\
\text { muito superficial sobre o que era indução. Isso } \\
\text { implica, em primeiro lugar, aspectos centrais, } \\
\text { fundamentais de lógica, que é um problema sério na } \\
\text { nossa educação ao distanciar filosofia da educação } \\
\text { básica, da educação média, da educação avançada } \\
\text { ou superior dos cientistas, você distancia também a } \\
\text { lógica, porque ela tem sido tradicionalmente... com o } \\
\text { sistema de um sistema maior do conhecimento } \\
\text { científico. } \\
\text { A distinção de leis e teorias a... o conceito de teoria, } \\
\text { principalmente é pensado e é utilizado de uma forma }\end{array}$ \\
\hline
\end{tabular}




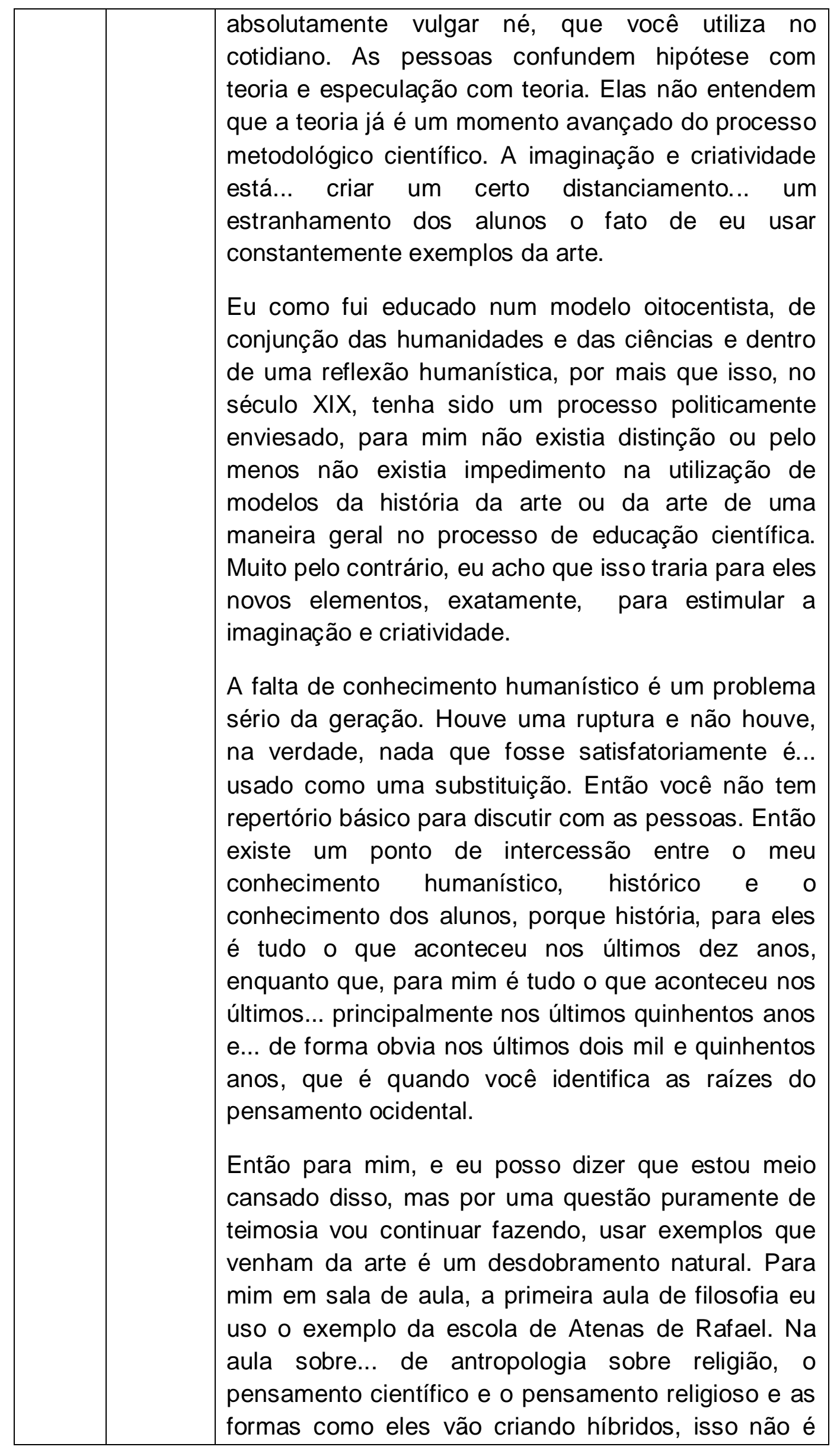




\begin{tabular}{|c|c|c|}
\hline & & $\begin{array}{l}\text { uma palavra boa, mas mestiços entre essas duas } \\
\text { formas de conhecimento e tentando, inclusive, criar } \\
\text { combinações que até certo ponto são absurdas para } \\
\text { mim, para qualquer cientista, e tem uma parte prática } \\
\text { científica que é a grande... o grande salto da ciência } \\
\text { se dá com a ruptura com a religião. Você cria } \\
\text { problemas para a ciência que são muito grandes. } \\
\text { Você não vai substituir a religião como todo mundo } \\
\text { achava no século XIX, como os grandes intelectuais } \\
\text { achavam, mas ela vai... o que faz o conhecimento } \\
\text { científico, no sentido do impacto que ele teve nos } \\
\text { últimos quinhentos anos e particularmente o impacto } \\
\text { que ele teve nos últimos duzentos anos é, } \\
\text { exatamente, o fato de ele ter... ele ter separado as } \\
\text { perguntas. Essa pergunta é filosófica, a razão do } \\
\text { ser... a existência de Deus, a existência de entidades } \\
\text { metafísicas... a compreensão desse sentimento, das } \\
\text { virtudes que vão buscar da filosofia, pelo menos no } \\
\text { seu sentido mais denso, mais profundo e a ciência } \\
\text { que vai trabalhar com aspectos causais que são mais } \\
\text { imanentes. Então se você con... contaminar não é } \\
\text { uma boa palavra, mas se você retorna a essa forma } \\
\text { de fazer conhecimento onde as duas coisas tão } \\
\text { interligadas, você não é justo nem para religião nem } \\
\text { com a ciência. Você diminui a ciência ao tentar fazer } \\
\text { das perguntas da religião as perguntas científicas e } \\
\text { você diminui a religião, ou pelo menos o pensamento } \\
\text { místico religioso ao tentar fazer ele responder as } \\
\text { perguntas da ciência. Então, na verdade, você... é... } \\
\text { mistifica isso e você perde o aspecto mais impactante } \\
\text { da religião que é o mistério. Se a religião perde o } \\
\text { mistério ela perde tudo. }\end{array}$ \\
\hline E21 & $18: 19$ & $\begin{array}{l}\text { Eu: Na... Algum de alguma das disciplinas, que... } \\
\text { alguma prática ou alguma coisa que o senhor } \\
\text { trabalhe especificamente, alguns pontos ou uma } \\
\text { preocupação. }\end{array}$ \\
\hline E22 & $18: 35$ & $\begin{array}{l}\text { Rui: Sim, nós fazemos vários debates e eles tem, } \\
\text { normalmente, alguns textos e no ano, não esse ano } \\
\text { que você fez, mas no ano anterior em Antropologia a } \\
\text { gente exibia filmes. }\end{array}$ \\
\hline E23 & $18: 49$ & Eu: No ano de $2010 ?$ O senhor lembra? \\
\hline
\end{tabular}




\begin{tabular}{|l|l|l|}
\hline E24 & 18:51 & $\begin{array}{l}\text { Rui: Não, em 2011. Esse ano já não teve. Porque a } \\
\text { ideia do cinema é a grande forma artística do século } \\
\text { XX e eu... É dif́cil você pensar no cinema } \\
\text { obviamente como todo o momento histórico que uma } \\
\text { forma de manifestação artística está sendo } \\
\text { explorada, experimentada, o que aconteceu no } \\
\text { século XX foi excepcional. Como eu não posso, na } \\
\text { Antropologia, dar grandes etnografias para eles } \\
\text { lerem, eu faço, nitidamente, eles fazerem uma } \\
\text { análise antropológica de grandes filmes. Com uma } \\
\text { narrativa ai vem o estímulo da criatividade, o } \\
\text { estímulo... o estranhamento intelectual... isso é algo, } \\
\text { por exemplo, alienígena aos alunos. Estranhamento } \\
\text { intelectual, para eles, é considerado uma forma... um } \\
\text { obstáculo... uma... um incômodo e eles na verdade } \\
\text { tende ser um processo intelectual obrigatório. Ao } \\
\text { desafiar algo, ao ser desafiado nas suas concepções } \\
\text { mais básicas ele vai buscar uma reflexão mais } \\
\text { profunda e... alternativas. Então a gente exibir esses } \\
\text { filmes, sempre volta para temas específicos do curso. } \\
\text { E normalmente escolhido por eles: idade, relações... } \\
\text { as relações entre mãe e filho, elementos importantes } \\
\text { da teoria da evolução humana. }\end{array}$ \\
\hline E25 & $\begin{array}{l}\text { Eu: Na Antropologia? } \\
\text { E26 }\end{array}$ \\
\hline $20: 34$ & $\begin{array}{l}\text { Rui: E na Filosofia, o debate ético, por exemplo, } \\
\text { quando eles criavam sobre o direito dos animais. E é } \\
\text { um debate que tem enorme apelo para eles porque é } \\
\text { um debate que abarca todos os campos da vida } \\
\text { deles. Eu pensar na relação que eles têm com os } \\
\text { animais de estimação e na sociabilidade que eles } \\
\text { criam, que nós criamos com os animais domésticos, } \\
\text { ao mesmo tempo pensar na enorme crueldade que } \\
\text { nós os tratamos, principalmente se pensarmos em } \\
\text { forma de... de... produção industrial em escala de } \\
\text { alimento, você é obrigado a enfrentar contradições e } \\
\text { paradoxos que são extremamente incômodos para } \\
\text { eles. É todo um problema da relação ética com os } \\
\text { animais de laboratório. O simples fato de você poder } \\
\text { dar um nome ao animal, que cria uma proximidade } \\
\text { afetiva, pode ter consequências enormes. Então é } \\
\text { um tema que tem enorme apelo para eles. A relação, } \\
\text { por exemplo, entre religião... dentro da... da... da }\end{array}$ \\
\hline
\end{tabular}




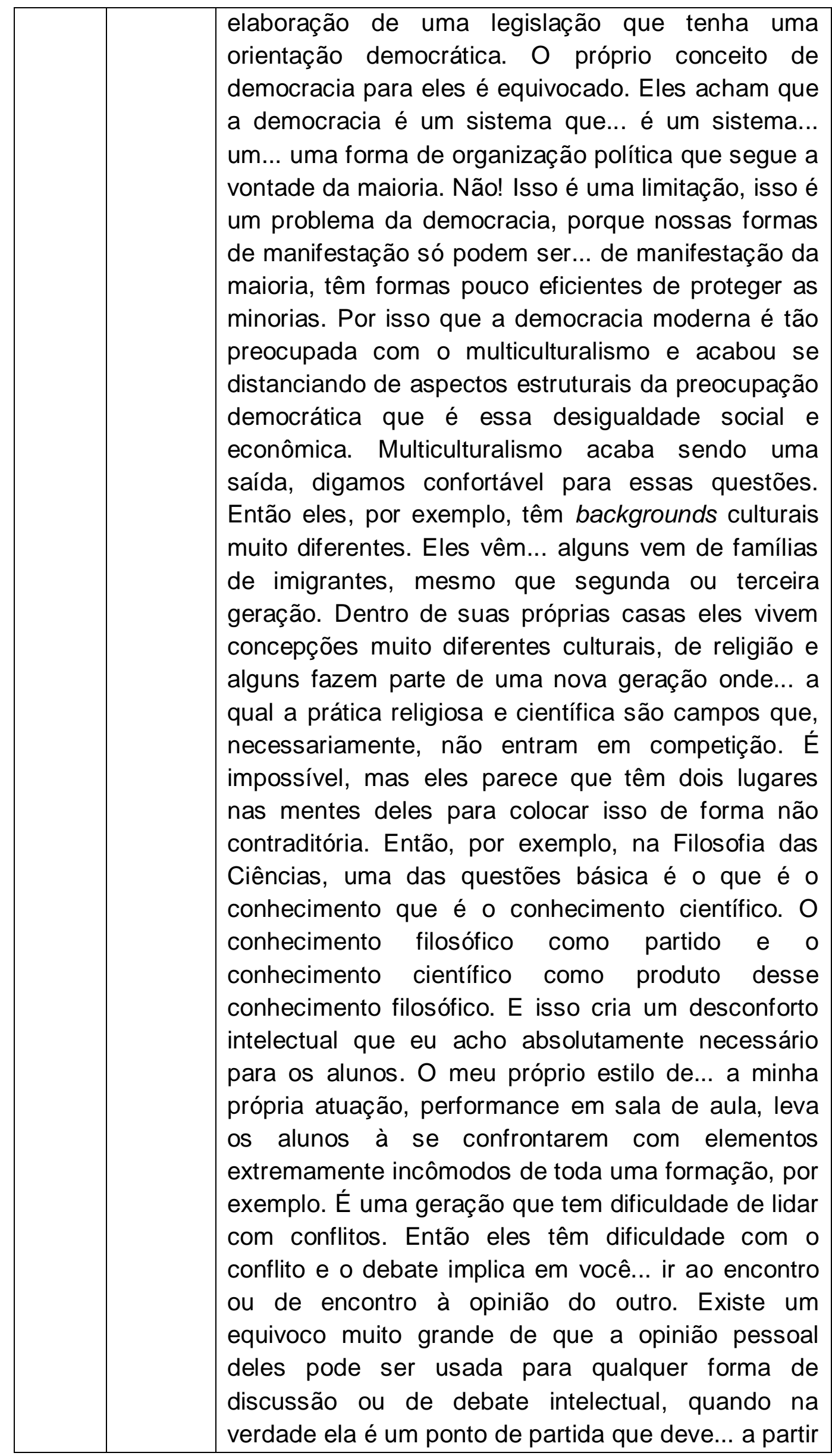




\begin{tabular}{|c|c|c|}
\hline & & $\begin{array}{l}\text { de um certo momento ser neutralizada ou, pelo } \\
\text { menos, ser suspensa, como diziam os gregos. }\end{array}$ \\
\hline E27 & $25: 12$ & $\begin{array}{l}\text { Eu: E nas avaliações como... como é trabalhado nas } \\
\text { avaliações das disciplinas e se o senhor cobra essa... } \\
\text { algum desenvolvimento nessa... }\end{array}$ \\
\hline E28 & $25: 26$ & Rui: Claro! \\
\hline E29 & $25: 27$ & Eu: Provavelmente. \\
\hline E30 & $25: 28$ & $\begin{array}{l}\text { Rui: Bom, eu acredito em leitura e escrita... eu } \\
\text { acredito em muita leitura e escrita. O problema maior, } \\
\text { eu acho, da geração de vocês... um dos grandes } \\
\text { problemas da geração de vocês é a perda de } \\
\text { parâmetros. Na minha geração, pode já não ser o } \\
\text { melhor parâmetro do mundo tinha... a de vocês foi } \\
\text { perdido e vocês vivem na ilusão que a opinião } \\
\text { pessoal de vocês e os parâmetros que vocês criam } \\
\text { no cotidiano de vocês são válidos ou satisfatórios. Eu } \\
\text { acho que não é nem uma coisa nem outra. Então, ao } \\
\text { confrontar as pessoas com uma multiplicidade de } \\
\text { ideias... dentro dessa perspectiva de que o } \\
\text { incomodo, o conflito, como parte inerente do } \\
\text { aprendizado, você os obriga a lidar com a própria } \\
\text { fluidez das ideias, das noções que eles alimentam e } \\
\text { que foram repassadas durante a formação primaria e } \\
\text { secundária deles e eles estão agora reproduzindo } \\
\text { isso numa prática que... precisa engajar formas mais } \\
\text { sofisticadas de reprodução. }\end{array}$ \\
\hline E31 & $26: 59$ & Eu: E algum... \\
\hline E32 & $27: 01$ & $\begin{array}{l}\text { Rui: Então assim... todos escrevem sobre... todos os } \\
\text { dias os grupos têm de escrever uma pergunta que } \\
\text { eles retiraram do texto, que eles acham que é } \\
\text { importante, eles têm que exemplificar a pergunta. } \\
\text { Isso é uma coisa também interessante. Eles } \\
\text { desconhecem a dialética como método de } \\
\text { aprendizado, porque a dialética que foi passada para } \\
\text { eles, o debate em sala de aula, é um debate } \\
\text { conformista, então é um debate confortável. No fundo } \\
\text { eles não estão sendo desafiados nas noções mais } \\
\text { elementares da vida deles, nessas noções de } \\
\text { pequenos burgueses. Quando você é desafiado } \\
\text { nesses elementos que no fundo fundamental o seu }\end{array}$ \\
\hline
\end{tabular}




\begin{tabular}{|c|c|c|}
\hline & & $\begin{array}{l}\text { cotidiano, a sua segurança ontológica, ai você cria o } \\
\text { incomodo. E ai, pelo menos para aqueles que são } \\
\text { mais talentosos, isso cria uma necessidade de } \\
\text { reflexão, que ai sim é filosófico. Então, para eles, eles } \\
\text { tendem... existe uma... eu acho que é um problema } \\
\text { desse novo movimento didático pedagógico, } \\
\text { pedagógico no Brasil que eles precisam se sentir } \\
\text { felizes, confortáveis. É uma doutrina completamente } \\
\text { pequeno burguesa. A partir do momento que ela } \\
\text { pega a reflexão do debate, esse debate precisa ser } \\
\text { confortável. E um debate que trabalha elementos } \\
\text { fundamentais que desafia as noções, os conceitos } \\
\text { fundamentais da sua vida nunca vai ser confortável. } \\
\text { Então eles não podem... eles querem que você os } \\
\text { entretenha, eles não querem ser incomodados, eles } \\
\text { não querem ser... eles querem estar em sala de aula } \\
\text { e fazer daquilo tudo uma forma de brincadeira. Isso é } \\
\text { uma noção absolutamente burguesa do mundo... } \\
\text { porque a nossa sociedade distanciou o sofrimento, a } \\
\text { dor, a reflexão densa, para conseguir criar uma } \\
\text { sociedade que se questiona pouco... e quando faz } \\
\text { isso faz em espaços seguros. }\end{array}$ \\
\hline E33 & $29: 26$ & $\begin{array}{l}\text { Eu: Você acha que é uma preocupação dos outros } \\
\text { colegas... }\end{array}$ \\
\hline E34 & 29:31 & $\begin{array}{l}\text { Rui: Não! Não. Não. Eles conseguem intuir isso, mas } \\
\text { não está claro na mente deles. }\end{array}$ \\
\hline E35 & $29: 42$ & Eu: A ponto dele cobrar também... \\
\hline E36 & $29: 43$ & $\begin{array}{l}\text { Rui: Isso. Os alunos acham, normalmente, que eu } \\
\text { sou sádico. A maneira como eles me abordam, isso } \\
\text { no começo, depois a coisa muda, mas eles me } \\
\text { abordam como se a maneira que eu interajo com eles } \\
\text { em sala de aula fosse um produto... um desejo } \\
\text { perverso. Eles só vão perceber que essa forma... } \\
\text { essa maneira agressiva que eu tenho de elaborar } \\
\text { sobre o conflito, com um desconforto intelectual, é } \\
\text { uma forma deles se questionarem. Ao se sentir, por } \\
\text { exemplo, incomodados às minhas noções de } \\
\text { hierarquia, de autoridade, eles vão perguntar } \\
\text { realmente se o que eles aprenderam, eles } \\
\text { estudaram, realmente, vai... reflete o mundo ou pelo } \\
\text { menos reflete um mundo que você pensa em almejar }\end{array}$ \\
\hline
\end{tabular}




\begin{tabular}{|l|l|l|}
\hline E37 & $30: 51$ & de forma satisfatória. \\
\hline E38 É isso? \\
\hline 30:52 & $\begin{array}{l}\text { Rui: Tem uma coisa aqui que é muito importante. Na } \\
\text { Antropologia, um dos temas interessantes, na } \\
\text { Filosofia de certa forma, damos também, é a } \\
\text { influência cultural sobre a ciência. O viés cultural que } \\
\text { fez parte, principalmente de uma preocupação } \\
\text { antropológica. Todo o alcance das noções morais } \\
\text { que são herdadas de uma visão cultural de mundo, } \\
\text { isso é uma grande contribuição da antropologia do } \\
\text { século XX. Mas eles, por exemplo, têm uma certa } \\
\text { visão, muitas vezes ingênua de achar que a visão } \\
\text { desconstrutivista que eles trazem da escola, que leva } \\
\text { a um certo linismo das coisas e a um relativismo, } \\
\text { absolutamente, selvagem ou, pelo menos, sem } \\
\text { fronteiras, é uma maneira satisfatória deles pensarem } \\
\text { o mundo. No fundo eles tão contra as regras por } \\
\text { definição, sem entender que as regras também } \\
\text { fazem parte do próprio processo, mesmo que } \\
\text { desconstruindo uma certa forma de pensar o mundo } \\
\text { que é originária do século XIX, eles acham que isso } \\
\text { vai levá-los a uma resposta satisfatória de como agir, } \\
\text { como praticar a disciplina e a formação que eles } \\
\text { esperam, colocar em prática. }\end{array}$ \\
\hline E39 & $32: 26$ & \begin{tabular}{l} 
Eu: É isso professor! \\
\hline
\end{tabular} \\
\hline
\end{tabular}




\section{ANEXO 5: Questionário VNOS-C}

Instruções:

Por favor, responda cada uma das seguintes questões na ordem em que aparecem no questionário. Inclua exemplos relevantes sempre que possível. Não há respostas "certas" ou "erradas" para as seguintes questões. Nós estamos interessados apenas em sua opinião sobre um conjunto de questões acerca da ciência.

1. Na sua visão, o que é ciência?

2. O que torna a ciência (ou uma disciplina científica como a física, a biologia etc.) diferente de outras formas de investigação (por exemplo, religião, filosofia)?

3. O que é um experimento?

4. O desenvolvimento do conhecimento científico requer experimentos?

a) Se sim, explique por que. Dê um exemplo para defender sua posição.

b) Se não, explique por que. Dê um exemplo para defender sua posição.

5. Livros-texto de ciência frequentemente representam o átomo como um núcleo central composto de prótons (partículas carregadas positivamente) e nêutrons (partículas neutras), com elétrons (partículas carregadas negativamente) orbitando ao redor daquele núcleo. Qual o grau de certeza que os cientistas têm acerca da estrutura do átomo? Que evidência específica, ou tipos de evidência, você pensa que os cientistas utilizaram para determinar com que um átomo se parece?

6. Você acha que há diferença entre uma teoria científica e uma lei científica?

a) Se sim, explique por que. Dê um exemplo para defender sua posição.

b) Se não, explique por que. Dê um exemplo para defender sua posição. 
7. Após os cientistas terem desenvolvido uma teoria científica (por exemplo, a teoria atômica, a teoria da evolução), a teoria pode transformar-se?

a) Se você acredita que as teorias científicas não mudam, explique por que. Defenda sua resposta com exemplos.

b) Se você acredita que as teorias científicas de fato mudam:

(b1) Explique por que as teorias mudam.

(b2) Explique por que nós nos preocupamos em aprender teorias científicas, considerando que as teorias que aprendemos poderão mudar. Defenda sua resposta com exemplos.

8. Livros-texto de ciências definem uma espécie como um grupo de organismos que compartilham características similares e podem cruzar uns com os outros produzindo filhos férteis. Qual o grau de certeza que os cientistas têm acerca de sua caracterização do que é uma espécie? Que evidência específica você pensa que os cientistas utilizaram para determinar o que é uma espécie?

9. Acredita-se que há cerca de 65 milhões de anos os dinossauros se extinguiram. Entre as hipóteses formuladas pelos cientistas para explicar a extinção, duas gozam de maior apoio. A primeira, formulada por um grupo de cientistas, sugere que um imenso meteorito atingiu a Terra há 65 milhões de anos e acarretou uma série de eventos que causou a extinção. A segunda hipótese, formulada por um outro grupo de cientistas, sugere que grandes e violentas erupções vulcânicas foram responsáveis pela extinção. Como essas conclusões diferentes são possíveis se os cientistas de ambos os grupos tiveram acesso e utilizaram o mesmo conjunto de dados para obter suas conclusões?

10. Os cientistas realizam experimentos/investigações científicas quando estão tentando encontrar respostas para as questões que eles propuseram. Os cientistas usam sua criatividade e imaginação durante suas investigações?

a) Se sim, então em que estágios das investigações você acredita que os cientistas utilizam sua imaginação e criatividade: projeto e planejamento; coleta de dados; após a coleta de dados? Por favor, explique por que os cientistas usam a imaginação e a criatividade. Forneça exemplos se for apropriado. 
b) Se você acredita que cientistas não usam a imaginação e a criatividade, por favor, explique por que. Forneça exemplos se for apropriado.

11. Algumas pessoas afirmam que a ciência é impregnada por valores sociais e culturais. Isto é, a ciência reflete os valores sociais e políticos, as suposições filosóficas e as normas intelectuais da cultura na qual ela é praticada. Outras pessoas afirmam que a ciência é universal. Isto é, a ciência transcende as fronteiras nacionais e culturais e não é afetada por valores sociais, políticos e filosóficos e pelas normas intelectuais da cultura na qual ela é praticada.

a) Se você acredita que a ciência reflete valores sociais e culturais, explique por que e como. Defenda sua resposta com exemplos.

b) Se você acredita que a ciência é universal, explique por que e como. Defenda sua resposta com exemplos. 


\section{ANEXO 6: Questionário VOSE}

\section{Questionário para levantamento dos pontos de vista sobre Ciências e Educação em Ciências}

\section{Instruções aos participantes:}

Cada pergunta do questionário começa com uma afirmação sobre a natureza da ciência ou educação científica. A maioria das afirmações adota um ponto de vista radical. Você pode concordar totalmente com ele, discordar totalmente, ou ter outras opiniões a respeito. Cada afirmação é seguida por diversas respostas. Por favor, primeiro, leia todas as respostas; em seguida, assinale a sua opinião (DT, DP, I, CP, CT) no lado direito de cada resposta de acordo com o seu conhecimento das atividades científicas, dos cientistas e do que deveria ser ensinado nos cursos de ciências. Não há uma resposta certa ou errada. Obrigado.

$$
\begin{gathered}
\mathrm{DT}=\text { Discordo totalmente } \\
\mathrm{DP}=\text { Discordo parcialmente } \\
\mathrm{I}=\text { Incerto ou nenhum comentário } \\
\mathrm{CP}=\text { Concordo parcialmente } \\
\mathrm{CT}=\text { Concordo totalmente }
\end{gathered}
$$

1. Quando surgem duas teorias diferentes para explicar o mesmo fenômeno (por exemplo, fósseis de dinossauros), os cientistas aceitam as duas teorias ao mesmo tempo?

A. Sim, porque os cientistas ainda não podem dizer

$\begin{array}{lllll}\text { DT } & \text { DP } & \text { I } & \text { CP } & \text { CT }\end{array}$

objetivamente qual é melhor, portanto, eles vão aceitar

ambas provisoriamente.

B. Sim, porque as duas teorias podem fornecer

DT DP I $\quad$ CP $\quad$ CT

explicações a partir de perspectivas diferentes, não há

certo ou errado.

C. Não, porque os cientistas tendem a aceitar a teoria $\quad$ DT $\quad$ DP $\quad$ I $\quad$ CP $\quad$ CT

com que estão mais familiarizados.

$\begin{array}{llllll}\text { D. Não, porque os cientistas tendem a aceitar as teorias } & \text { DT } & \text { DP } & \text { I } & \text { CP } & \text { CT }\end{array}$

mais simples e a evitar teorias complexas.

E. Não, o status acadêmico de cada teoria irá influenciar $\quad$ DT $\quad$ DP $\quad$ I $\quad$ CP $\quad$ CT

a aceitação da teoria pelos cientistas.

F. Não, os cientistas tendem a aceitar as novas teorias $\quad$ DT $\quad$ DP $\quad$ I $\quad$ CP $\quad$ CT

que se afastam menos do núcleo da teoria científica

contemporânea.

$\begin{array}{llllll}\text { G. Não, os cientistas usam a intuição para fazer } & \text { DT } & \text { DP } & \text { I } & \text { CP } & \text { CT }\end{array}$ 
julgamentos.

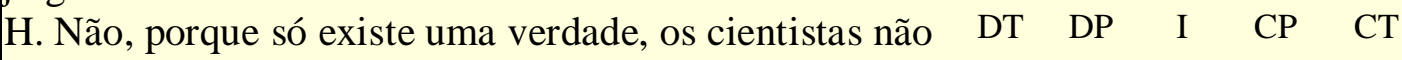

aceitarão qualquer teoria antes de distinguir qual é a

melhor.

2. Investigações científicas são influenciadas por valores socioculturais (por exemplo, tendências atuais, valores).

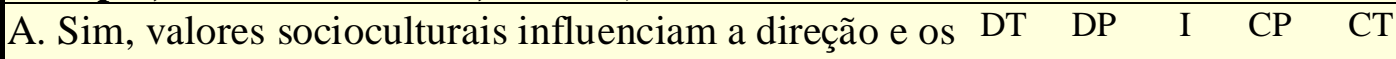

tópicos de investigação científica.

B. Sim, porque os cientistas que realizam investigações $\quad$ DT $\quad$ DP $\quad$ I $\quad$ CP $\quad$ CT

científicas são influenciados por valores socioculturais.

$\begin{array}{llllll}\text { C. Não, cientistas com boa formação permanecerão } & \text { DT } & \text { DP } & \text { I } & \text { CP } & \text { CT }\end{array}$

isentos de valores quando realizarem suas pesquisas.

D. Não, porque a ciência requer objetividade, o que é $\quad$ DT $\quad$ DP $\quad$ I $\quad$ CP $\quad$ CT

contrário à subjetividade dos valores socioculturais.

3. Quando os cientistas estão conduzindo uma investigação científica, eles usam sua imaginação?

A. Sim, a imaginação é a principal fonte de inovação.

B. Sim, os cientistas usam um pouco da sua imaginação

na investigação científica.

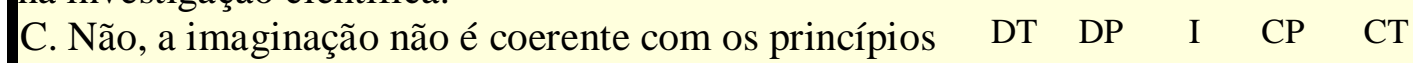

lógicos da ciência.

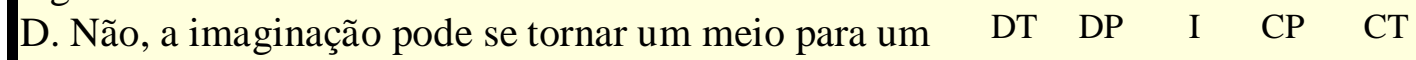

cientista provar seu ponto de vista a todo custo.

$\begin{array}{llllll}\text { E. Não, a imaginação não tem confiabilidade. } & \text { DT } & \text { DP } & \text { I } & \text { CP } & \text { CT }\end{array}$

4. Mesmo que as investigações científicas sejam realizadas corretamente, a teoria proposta ainda pode ser contestada no futuro.
A. A investigação científica enfrentará mudança
$\begin{array}{lllll}\text { DT } & \text { DP } & \text { I } & \text { CP } & \text { CT }\end{array}$
revolucionária, e a teoria antiga será substituída.
B. Avanços científicos não podem ser feitos em um curto DT $\quad$ DP $\quad$ I $\quad$ CP $\quad$ CT
espaço de tempo. Acontecem por meio de um processo
cumulativo, portanto, a velha teoria é preservada.
C. Com o acúmulo de dados de pesquisa e de
informação, a teoria irá evoluir de forma mais precisa e
completa, não sendo contestada.

5. A teoria científica (por exemplo, seleção natural, teoria atômica) é

"descoberta" ou "inventada" pelos cientistas a partir do mundo natural?

$\begin{array}{llllll}\text { A. Descoberta, porque a ideia estava lá o tempo todo } & \text { DT } & \text { DP } & \text { I } & \text { CP } & \text { CT }\end{array}$

para ser descoberta.

B. Descoberta, porque se baseia em dados experimentais. DT $\quad$ DP $\quad$ I $\quad$ CP $\quad$ CT

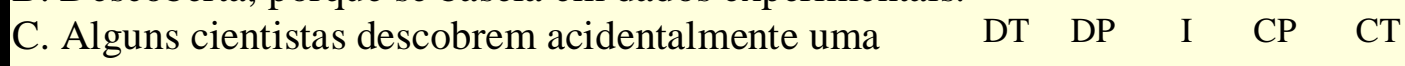

teoria, mas outros cientistas podem inventar uma teoria a

partir de fatos que conhecem.

D. Inventada, porque uma teoria é uma interpretação de $\quad$ DT $\quad$ DP $\quad$ I $\quad$ CP $\quad$ CT

dados experimentais, e dados experimentais são

descobertos pelos cientistas. 


\begin{tabular}{|c|c|c|c|c|c|}
\hline $\begin{array}{l}\text { E. Inventada, porque uma teoria é criada ou elaborada } \\
\text { pelos cientistas. } \\
\text { F. Inventada, porque uma teoria pode ser refutada. }\end{array}$ & DT & DP & I & $\mathrm{CP}$ & CT \\
\hline \multicolumn{6}{|c|}{$\begin{array}{l}\text { 6. Uma lei científica (por exemplo, lei gravitacional) é "descoberta" ou } \\
\text { "inventada" pelos cientistas a partir do mundo natural? }\end{array}$} \\
\hline $\begin{array}{l}\text { A. Descoberta, porque as leis científicas estão lá, na } \\
\text { natureza, e os cientistas apenas têm que encontrá-las. }\end{array}$ & DT & DP & I & $\mathrm{CP}$ & $\mathrm{CT}$ \\
\hline $\begin{array}{l}\text { B. Descoberta, porque as leis científicas são baseadas em } \\
\text { dados experimentais. }\end{array}$ & DT & DP & I & $\mathrm{CP}$ & CT \\
\hline $\begin{array}{l}\text { C. Alguns cientistas descobrem acidentalmente uma lei, } \\
\text { mas outros cientistas podem inventar uma lei a partir dos } \\
\text { fatos que conhecem. }\end{array}$ & DT & DP & I & $\mathrm{CP}$ & CT \\
\hline $\begin{array}{l}\text { D. Invenção, porque os cientistas inventam as leis } \\
\text { científicas para interpretar dados experimentais } \\
\text { descobertos. }\end{array}$ & DT & DP & I & $\mathrm{CP}$ & $\mathrm{CT}$ \\
\hline $\begin{array}{l}\text { E. Invenção, uma vez que não existem absolutos na } \\
\text { natureza, portanto, a lei é inventada pelos cientistas. }\end{array}$ & DT & DP & I & $\mathrm{CP}$ & $\mathrm{CT}$ \\
\hline
\end{tabular}

\begin{tabular}{|c|c|c|c|c|c|}
\hline \multicolumn{6}{|c|}{ 7. Em comparação com as leis, as teorias têm menos evidências para apoiá-las. } \\
\hline A. Sim, as teorias não são tão definidas como as leis. & DT & DP & I & $\mathrm{CP}$ & CT \\
\hline $\begin{array}{l}\text { B. Sim, se uma teoria resiste a muitos testes ela acabará } \\
\text { por se tornar uma lei; portanto, uma lei tem mais } \\
\text { evidências que a fundamentam. }\end{array}$ & DT & DP & I & $\mathrm{CP}$ & $\mathrm{CT}$ \\
\hline $\begin{array}{l}\text { C. Não exatamente; algumas teorias têm mais evidências } \\
\text { que as fundamentam do que algumas leis. }\end{array}$ & DT & DP & I & $\mathrm{CP}$ & CT \\
\hline $\begin{array}{l}\text { D. Não, teorias e leis são diferentes tipos de ideias. Elas } \\
\text { não podem ser comparadas. }\end{array}$ & DT & DP & I & $\mathrm{CP}$ & $\mathrm{CT}$ \\
\hline
\end{tabular}

8. As observações dos cientistas são influenciadas pelas crenças pessoais (por exemplo, experiências pessoais, as pressuposições); portanto, eles não podem fazer as mesmas observações para o mesmo experimento.

\begin{tabular}{|c|c|c|c|c|c|}
\hline $\begin{array}{l}\text { A. As observações serão diferentes, porque crenças } \\
\text { diferentes levam a diferentes expectativas que } \\
\text { influenciam a observação. }\end{array}$ & DT & DP & I & $\mathrm{CP}$ & $\mathrm{CT}$ \\
\hline $\begin{array}{l}\text { B. As observações serão as mesmas, porque os cientistas } \\
\text { treinados na mesma área defendem ideias semelhantes. }\end{array}$ & DT & DP & I & $\mathrm{CP}$ & $\mathrm{CT}$ \\
\hline $\begin{array}{l}\text { C. As observações serão as mesmas, porque através da } \\
\text { formação científica os cientistas podem abandonar os } \\
\text { valores pessoais para realizar observações objetivas. }\end{array}$ & DT & DP & I & $\mathrm{CP}$ & $\mathrm{CT}$ \\
\hline $\begin{array}{l}\text { D. As observações serão as mesmas, porque as } \\
\text { observações são exatamente o que nós vemos e nada } \\
\text { mais. Fatos são fatos. Interpretações podem ser diferentes } \\
\text { de uma pessoa para outra, mas as observações devem ser } \\
\text { as mesmas. }\end{array}$ & DT & DP & I & $\mathrm{CP}$ & $\mathrm{CT}$ \\
\hline $\begin{array}{l}\text { E. As observações serão as mesmas. Embora a } \\
\text { subjetividade não possa ser totalmente evitada na } \\
\text { observação, os cientistas utilizam métodos diferentes } \\
\text { para verificar os resultados e melhorar a objetividade. }\end{array}$ & DT & $\mathrm{DP}$ & I & $\mathrm{CP}$ & $\mathrm{CT}$ \\
\hline
\end{tabular}


9. A maioria dos cientistas segue o método científico universal, passo-a-passo, para fazer suas pesquisas (por exemplo, propor uma hipótese, planejar um experimento, coletar dados e tirar conclusões).

A. O método científico assegura resultados válidos,

$\begin{array}{lllll}\text { DT } & \text { DP } & \text { I } & \text { CP } & \text { CT }\end{array}$

claros, lógicos e exatos. Assim, a maioria dos cientistas

segue o método universal na pesquisa.

B. A maioria dos cientistas usa o método científico $\quad$ DT $\quad$ DP $\quad$ I $\quad$ CP $\quad$ CT

porque ele é um procedimento lógico.

C. O método científico é útil na maioria dos casos, mas $\quad$ DT $\quad$ DP $\quad$ I $\quad$ CP $\quad$ CT

ele não garante resultados; portanto, os cientistas

inventam novos métodos.

D. Não existe isso que é chamado o método científico. Os

cientistas usam qualquer método para obter resultados.

E. Não existe um método científico fixo; o conhecimento

científico poderia ser descoberto acidentalmente.

F. Não importa como os resultados são obtidos, os

cientistas usam o método científico para verificar isso.

\section{Estudantes do ensino médio devem aprender o procedimento do método} científico.

\begin{tabular}{|c|c|c|c|c|c|}
\hline $\begin{array}{l}\text { A. Sim, assim os alunos têm orientações para trabalhar } \\
\text { com ele. }\end{array}$ & DT & DP & I & $\mathrm{CP}$ & $\overline{\mathrm{CT}}$ \\
\hline $\begin{array}{l}\text { Sim, porque os alunos ainda são incapazes de elaborar } \\
\text { étodos mais adequados. }\end{array}$ & DT & DP & I & $\mathrm{CP}$ & $\mathrm{CT}$ \\
\hline aprender o que os cientistas fazem. & DT & DP & I & $\mathrm{CP}$ & $\mathrm{CT}$ \\
\hline hor método & DT & DP & & CP & CT \\
\hline prenderem um modo & DT & DP & I & $\mathrm{CP}$ & $\mathrm{CT}$ \\
\hline ajudar os alunos a compreender a & DT & DP & 1 & $\mathrm{CP}$ & $\mathrm{CT}$ \\
\hline $\begin{array}{l}\text { G. Não, nós não devemos ensinar apenas um método } \\
\text { científico. Os alunos devem ter espaço para pensar e } \\
\text { desenvolver os seus próprios métodos. }\end{array}$ & DT & DP & I & $\mathrm{C}$ & $\mathrm{CT}$ \\
\hline 1800 & DT & DI & I & $\mathrm{CP}$ & $\mathrm{CT}$ \\
\hline . Não, os professores e os alunos deverão debater & DT & DP & I & $\mathrm{CP}$ & $\mathrm{CT}$ \\
\hline
\end{tabular}

diferentes métodos de investigação em conjunto.

11. Em salas de aula de ciências do ensino médio, quando os alunos estão

observando o mesmo evento, o professor deve esperar que os alunos cheguem aos mesmos resultados.

\begin{tabular}{llllllll}
\hline $\begin{array}{l}\text { A. Sim, o professor deve orientar os alunos a realizar } \\
\text { observações objetivas para se obter resultados idênticos. }\end{array}$ & DT & DP & I & CP & CT \\
$\begin{array}{l}\text { B. Sim, se os alunos tomarem cuidado, eles devem } \\
\text { chegar a resultados iguais. }\end{array}$ & DT & DP & I & CP & CT \\
$\begin{array}{l}\text { C. Sim, dados experimentais não serão diferentes de } \\
\text { pessoa para pessoa; assim, não importa quem faz a } \\
\text { observação, o resultado será sempre o mesmo. }\end{array}$ & DT & DP & I & CP & CT \\
\hline
\end{tabular}




\begin{tabular}{|c|c|c|c|c|c|}
\hline $\begin{array}{l}\text { D. Não, a observação será afetada por preconceitos dos } \\
\text { alunos. } \\
\text { E. Não, o professor deve discutir com os alunos como a } \\
\text { observação pode ser afetada por preconceitos. }\end{array}$ & DT & DP & I & $\mathrm{CP}$ & $\mathrm{CT}$ \\
\hline \multicolumn{6}{|c|}{ 12. Os estudantes devem entender que o conhecimento científico pode mudar. } \\
\hline A. Sim, assim que perceberem a real natureza da ciência. & DT & DP & I & $\mathrm{CP}$ & $\mathrm{CT}$ \\
\hline $\begin{array}{l}\text { B. Sim, assim que perceberem a razão pela qual a ciência } \\
\text { avança. }\end{array}$ & DT & DP & I & $\mathrm{CP}$ & $\mathrm{CT}$ \\
\hline $\begin{array}{l}\text { C. Não, isso vai diminuir o interesse dos alunos na } \\
\text { aprendizagem da ciência. }\end{array}$ & DT & DP & I & $\mathrm{CP}$ & $\mathrm{CT}$ \\
\hline $\begin{array}{l}\text { D. Não, isso vai diminuir a aceitação que os alunos tem } \\
\text { da ciências. }\end{array}$ & DT & DP & I & $\mathrm{CP}$ & CT \\
\hline $\begin{array}{l}\text { E. Não, os estudantes só precisam aprender sobre os } \\
\text { fundamentos constantes do conhecimento científico. }\end{array}$ & DT & DP & I & $\mathrm{CP}$ & $\mathrm{CT}$ \\
\hline \multicolumn{6}{|c|}{$\begin{array}{l}\text { 13. O curso de ciências no ensino médio deve investigar as definiçõoes e as } \\
\text { relações entre hipótese, teoria e lei. }\end{array}$} \\
\hline $\begin{array}{l}\text { A. Sim, porque elas representam a estrutura do } \\
\text { conhecimento científico. }\end{array}$ & DT & DP & I & $\mathrm{CP}$ & CT \\
\hline $\begin{array}{l}\text { B. Sim, porque elas são os fundamentos da pesquisa } \\
\text { científica. }\end{array}$ & DT & DP & I & $\mathrm{CP}$ & CT \\
\hline $\begin{array}{l}\text { C. Não, sabendo que a definição e as relações entre estes } \\
\text { termos não ajudam muito na aprendizagem do } \\
\text { conhecimento científico. }\end{array}$ & DT & DP & I & $\mathrm{CP}$ & $\mathrm{CT}$ \\
\hline $\begin{array}{l}\text { D. Não, porque hipótese, teoria e lei não possuem seus } \\
\text { significados definidos. }\end{array}$ & DT & DP & I & $\mathrm{CP}$ & $\mathrm{CT}$ \\
\hline
\end{tabular}

Por favor, leia atentamente a seguinte história sobre dois cientistas antes de responder às duas últimas questões.

É o ano de 2016. A e B são professores em um centro de biotecnologia, e eles estão pesquisando a seleção e transferência de genes. Se o projeto tiver êxito, os seres humanos estarão livres de limitações congênitas. Além da total prevenção de doenças hereditárias, as pessoas serão livres para escolher e transferir seus genes. Os seres humanos nunca voltarão a ter deficiências congênitas hereditárias. A pesquisa já está na última etapa, mas o público em geral se opõe a ela, e até mesmo a própria instituição tem a intenção de cortar o orçamento.

Na verdade, A já está começando a questionar a continuação da investigação. A é um cristão devoto, acreditando que Deus irá abrir as portas para todos. Assim, mesmo que as pessoas nasçam com diversas doenças e deficiências, a diversidade e a imprevisibilidade da humanidade são características que criaram a história. A não acredita que o desenvolvimento científico deve alterar a essência do ser humano. Portanto, quando os valores socioculturais e crenças da ciência entram em conflito, a escolha deve ser feita 
com base nos valores socioculturais, porque os valores finais da ciência recaem sobre as pessoas.

Entretanto, $\mathbf{B}$ não pensa desta maneira. $\mathbf{B}$ acredita que a natureza da ciência é absolutamente objetiva, e que os valores socioculturais, assim como a preferência do público, sempre mudando com o meio social, são uma representação muito subjetiva de valores. Em outras palavras, a pesquisa que é rejeitada pelos valores socioculturais de hoje pode se tornar uma aspiração no futuro. Portanto, é insensato abandonar o caráter objetivo da ciência apenas por um valor subjetivo. B e A começam uma discussão sobre este assunto.

Finalmente, A escolhe se retirar da pesquisa, mas $\mathbf{B}$ opta por continuar a desenvolvê-la. Desde que abandonou as bem desenvolvidas técnicas de pesquisa, A mudou seu interesse de pesquisa, passando a estudar seleção genética e transferência gênica em plantas, em uma tentativa de escolher um tema aceito pelos valores socioculturais dominantes. A teve um eventual êxito com a transferência de genes que atuam contra o câncer, do Taxus mairei para o centeio, criando um centeio anticancerígeno. Olhando para trás, A não lamenta sua saída do projeto e acredita que, embora a natureza da ciência possa ser objetiva, a manifestação dos valores deve eventualmente voltar à essência fundamental de "seres humanos". B, persistindo em continuar o projeto original, teve sucesso em pesquisas com animais vivos e continuou a fazer pesquisas em seres humanos. B não se arrepende da escolha, quer e até trabalha mais no projeto por causa da crença de que essa história não termina aqui. Toda a natureza e valor da pesquisa serão revelados no futuro. Ficará na história, ao contrário dos valores socioculturais contemporâneos.

14. Da perspectiva do ensino de ciências, o que os estudantes de ensino médio podem aprender com estes dois cientistas?

$\begin{array}{llllll}\text { A. A - Cientistas devem ter consciência quanto à pesquisa que } & \text { DT } & \text { DP } & \text { I } & \text { CP } & \text { CT }\end{array}$

estão fazendo.

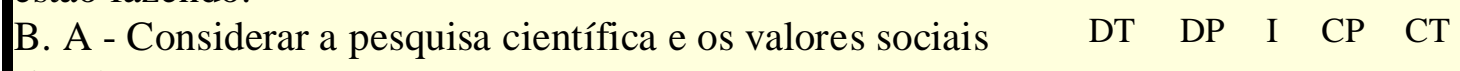

simultaneamente.

C. A - A investigação científica não pode ser totalmente $\quad$ DT $\quad$ DP $\quad$ I $\quad$ CP $\quad$ CT

separada dos valores socioculturais.

D. A - Respeitar a diversidade das pessoas.

E. B - A investigação científica deve ser totalmente

DT DP $\quad$ I $\quad$ CP $\quad$ CT

independente de crenças pessoais.

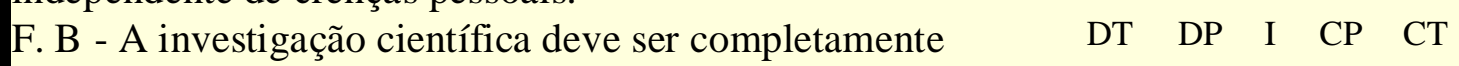

independente de valores sociais subjetivos.

G. Nenhum deles é um bom exemplo para se aprender, porque $\quad$ DT $\quad$ DP $\quad$ I $\quad$ CP $\quad$ CT

os cursos de ciências não devem envolver o valor das

escolhas.

15. Do ponto de vista da natureza da ciência, qual forma de pensar, entre os pesquisadores A e B, você concorda?

\begin{tabular}{lllllll}
\hline A. A - Cientistas devem ter consciência ao fazer a pesquisa. & DT & DP & I & CP & CT
\end{tabular}


B. A - Considerar a investigação científica e os valores

$\begin{array}{ccccc}\text { DT } & \text { DP } & \text { I } & \text { CP } & \text { CT } \\ \text { DT } & \text { DP } & \text { I } & \text { CP } & \text { CT } \\ & & & & \\ \text { DT } & \text { DP } & \text { I } & \text { CP } & \text { CT } \\ \text { DT } & \text { DP } & \text { I } & \text { CP } & \text { CT } \\ \text { DT } & \text { DP } & \text { I } & \text { CP } & \text { CT } \\ \text { DT } & \text { DP } & \text { I } & \text { CP } & \text { CT } \\ \text { DT } & \text { DP } & \text { I } & \text { CP } & \text { CT } \\ & & & & \\ \text { DT } & \text { DP } & \text { I } & \text { CP } & \text { CT } \\ & & & & \end{array}$




\section{Anexo 7: Transcrição das respostas dos alunos - questionário VNOS-C}

\section{Aluno 1 - Primeira etapa}

1.1.6 - a) Teoria científica difere de Lei Científica por não ter sido comprovada de modo plausível ou aceito pelos cientistas. Por exemplo, a Lei de Mendel foi considerada uma certeza.

1.1.7 - b) b1) As teorias mudam pois os métodos de investigação podem se tornar mais avançados e mostrar erros em tais teorias. b2) Nós aprendemos as teorias, pois delas podemos discordar, procurando outras respostas e colaborando com o aperfeiçoamento da ciência.

1.1.9 - Uma mesma evidência pode levar a diferentes conclusões pois a interpretação de um fato não é única, depende do ponto de vista e como cada cientista analisa.

1.1.10 - a) Os cientistas usam sua criatividade para imaginar situações para saber como coletar dados e como organizá-los.

1.1.11 - b) A ciência é universal na medida em que analisa fenômenos que são naturais e comuns a todas as culturas, por exemplo, um terremoto é o mesmo em todo a planeta. Mesmo que cada cultura o interprete de um modo, os cientistas são unânimes quanto à sua origem.

\section{Aluno 1 - Segunda etapa}

1.2.6 - Sim. Para mim, uma lei científica é considerada aceita, enquanto a teoria não foi aceita ou foi refutada. Existe, porém, leis que ainda são tratadas como teorias, apesar da aceitação pelos cientistas, como a Teoria da Evolução. As Leis de Kepler, voltando ao inicio, são ideias consideradas verdadeiras.

1.2.7 - b) As teorias mudam pois o modo de pensar é algo dinâmico e novas tecnologias possibilitam novas pesquisas, levando a conclusões que podem modificar uma teoria, sem refutá-la. b2) É importante aprender teorias para que aprendamos a questioná-las, propondo novos paradigmas e colaborando com o desenvolvimento da ciência. Um exemplo foi o desenvolvimento da genética, quando novos estudiosos passaram a propor novas teorias e a complementar a ideia mendeliana.

1.2.9 - As informações estão sujeitas a análise de um ser humano. Como sempre, o homem pode não conseguir olhar objetivamente para um fato pois 
há uma bagagem de conhecimento e vivência em cada um. Infelizmente, isso pode levar a diferentes conclusões a partir de um mesmo fato.

1.2.10 - a) Os cientistas utilizam a criatividade em todas as etapas de investigação científica, pois novos modelos mais eficientes podem surgir.

1.2.11 - b) A ciência não está impregnada de valores culturais pois as conclusões de um cientista válidas para todo o planeta, pois mesmo que a cultura de um pais não aceite essas conclusões, um cientista profissional deste mesmo país irá testá-la e ,se forem verdadeiras, aceitá-las.

\section{Aluno 2 - Primeira etapa}

2.1.6 - Sim, pois a teoria não foi totalmente comprovada, enquanto a lei científica foi. Entretanto, devido à constante evolução das ideias muitas vezes uma lei científica pode tornar-se ultrapassada ou incompleta, tornando-se, assim, uma teoria.

2.1.7 - b1) As teorias mudam porque o homem muda e novas ideias surgem a cada minuto. b2) as teorias muitas vezes são a base para uma série de desenvolvimentos científicos. Assim, ao tornarem-se antiquadas ou ultrapassadas, sempre haverá algo descoberto que ainda poderá ser utilizado ou complementado. Por exemplo o Darwinismo que depois de muito tempo foi complementado com a genética, gerando a hereditariedade.

2.1.9 - As conclusões diferem-se devido às diferenças do pensamento humano, pois os mesmos dados para pessoas de diferentes filosofias e mentalidades levam a divergências de resultados.

2.1.10 - Sim, pois é a imaginação que interpreta de diferentes modos um mesmo fato, permitindo divergências e complementações no projeto e planejamento e após a coleta de dados, na conclusão.

2.1.11 - A ciência reflete valores sociais e culturais, pois o homem encontra-se impregnado destes, tornando-se, assim, impossível dissociá-los do seu método de pensar, realizar experimentos e observar o mundo. Pode-se tomar como exemplo, nas ciências humanas o socialismo de Marx e Engels e o capitalismo, duas filosofias monoméricas antagônicas que tiveram por base classe sociais também antagônicas.

\section{Aluno 2 - Segunda etapa}


2.2.6 - Sim, enquanto uma lei descreve um padrão considerado pontual (lei da gravidade, por exemplo) uma teoria descreve alguns padrões que são considerados universais, envolvidos numa grossa malha de leis.

2.2.7 - b) As teorias mudam por que o mundo e o homem também mudam. Elas são, na verdade, "verdades conjecturais". b1) Kuhn descreve as revoluções científicas como o acúmulo de problemas sobre um paradigma que não consegue explicá-los, necessitando, assim, de um novo que explique tanto os fatos antigos como os novos problemas. Esse processo é cíclico. b2) Aprendemos as teorias conjecturais pó que sem elas não conseguiríamos progredir na ciência, uma vez que seria difícil mudar algo que você não conhece (baseando-se nas revoluções de Kuhn) e, além disso, o fato delas serem "ultrapassadas" não significa que serão inutilizadas.

2.2.9 - A mesma informação pode ser interpretada de diferentes modos, uma vez que a pesquisa é realizada por seres humanos com diferentes metodologias de observação e visões de mundo.

2.2.10 - a) Sim, pois a inferência de fatos assim como a sua especulação é necessária em muitas áreas como a sistemática e paleontologia, nas quais é necessária inferir a história de indivíduos muitas vezes apenas com fragmentos (após a coleta de dados).

2.2.11 - a) Sim, pois os fatos passam por um filtro para serem interpretados: a mente humana e essa não é, de modo algum, padronizada. Ela é totalmente moldada de acordo com a realidade única de cada indivíduo, gerando diferentes visões de mundo. Pode-se citar as diferenças entre a medicina ocidental e a oriental, a mistificação da ciência como algo "superior" em diversos Estados, assim como seu uso para fins políticos e manipulação.

\section{Aluno 3 - Primeira etapa}

3.1.6 - a) Uma teoria científica parece basear-se em hipóteses, que podem explicar fenômenos, porém sem sua real comprovação. Já uma lei científica parece que já há sua comprovação, ou seja, dado um certo $A$, a consequência será sempre B.

3.1.7 - b1) As teorias podem sofrer alterações à medida em que novas evidências vão sendo descobertas, sendo a partir da tecnologia ou de fósseis (ou qualquer outro meio). b2) Aprendemos as teorias mais recentes e elaboradas de forma que já começamos a estudar de um certo ponto do qual poderemos fazer novas contribuições, ao invés de iniciarmos alguma pesquisa já previamente realizadas.

3.1.9 - As evidências da época dos dinossauros foram interpretadas de duas maneiras distintas, de modo que ambas sejam plausíveis, embora nenhuma 
seja uma verdade completa, de forma que mesmo as evidências apontando em uma direção, a outra não poderá ser "desmentida".

3.1.10 - a) Os cientistas podem usar sua criatividade para elaborar uma hipótese plausível, depois de estudos e experimentos e a partir dos dados coletados. Pode-se usar no modo de coleta dos dados ou para realizar experimentos de dados, mas nunca alterando evidências.

3.1.11 - b) A ciência por ser fruto do conhecimento humano está sujeita à influências históricas e culturais. Por exemplo quando acreditavam que a Terra era quadrada e os monstros dos seus mares, havia certas dúvidas, podendo ser desvendadas após a exploração e o desenvolvimento da cartografia. Porém a partir do momento em que esse conhecimento se baseia apenas nas coletas de dados, experimentos, estudos e comprovações materiais ou plausíveis, esta se torna universal, colaborando para o universo científico.

\section{Aluno 3 - Segunda etapa}

3.2.6 - Uma teoria é menos certeira que uma lei. A leis se provam reais ou aceitas pela comunidade científica como real, podendo ser aplicadas para outros conhecimentos. O grau de certeza de uma teoria, apesar de se apoiar sobre inúmeros conhecimentos pode ser alto, mas pode ser substituído por outra que se prove melhor.

3.2.7 - b1) As teorias mudam porque novos conhecimentos são adquiridos, bem como a tecnologia para fazer novas observações e conhecimento. b2) Apenas com uma base já construída por outros é que podemos sair de algum ponto que não do zero e ter a possibilidade de evoluir, avançar além do que já foi alcançado.

3.2.9 - A formulação de diferentes hipóteses pode ocorrer para cientistas com uma base de formação diferente, bem como um nível de imaginação dispare. Além disso, podem considerar qualitativamente diferentes evidências, ou seja, dar mais valor a uma do que outra.

3.2.10 - a) Utilizam da imaginação porque nem tudo é observável e para poderem encadear uma sequência de fatos que envolvam uma série de evidências, é necessário um pouco de criatividade. Das partes para a execução de um projeto, o projeto em si é o que exige imaginação, pois a coleta e verificação dos dados já são algo concreto que funcionam (falam) por si só.

3.2.11 - a) A ciência sempre está num contexto histórico-cultural, sendo impossível desvinculá-la de valores humanos. Apesar de existirem cientistas que vivam além do seu tempo (Copérnico, Galileu, Da Vinci) desenvolvimento de suas pesquisas não pode se desenvolver pela pressão social e às vezes falta dos instrumentos necessários. É verdade que pode ocorrer o 
desenvolvimento de uma ciência universal (verdades que se provem reais), porém nem por isso precisa deixar de ter um contexto certo para que se desenvolvam plenamente ou possam ser entendidas.

\section{Aluno 4 - Primeira etapa}

4.1.6 - a) Sim, há diferenças entre a teoria e lei cientifica uma vez que a teoria não foi comprovada e a lei é tida como "verdade universal", como a teoria das estruturas do átomo, que mudam com o tempo e a lei da inércia, que foi comprovada.

4.1.7 - Sim, as teorias científicas podem se transformar, uma vez que as novas pesquisas podem vir a complementa-las ou, até mesmo, derruba-las, nós nos preocupamos em aprender essas teorias justamente para realizar experimentos baseados nelas para podermos complementar a ciência (como foi o caso da "recente" descoberta de que Plutão não é um planeta e a descoberta de um novo planeta).

4.1.9 - Quando uma pesquisa é realizada, diferentes análises do mesmo material podem acarretar na formulação de diferentes teorias em relação ao mesmo fato (e ambas podem ser plausíveis).

4.1.10 - Sim, os cientistas utilizam a criatividade e a imaginação para a formulação de teorias durante as suas investigações após a coleta de dados, uma vez que todos os "fatos" já foram pesquisados e falta descobrir o que aconteceu (como é o caso da teoria do Big Bang e da extinção dos dinossauros).

4.1.11 - De certa maneira, a ciência valores sociais e culturais uma vez que pesquisas (como as de células-tronco) podem ser atrapalhadas devido à aplicação de valores morais e religiosos nas leis que influenciam ou regem a ciência e sua prática.

\section{Aluno 4 - Segunda etapa}

4.2.6 - Sim, uma teoria ainda não foi comprovada e precisa de experimentos para ser testada, já uma lei se aplica à todos os casos e foi comprovado.

4.2.7 - Sim, as teorias podem mudar conforme os experimentos realizados provem que essas são verdadeiras ou falsas (se forem falsas, é necessário formular teorias novas). Nós nos preocupamos em aprender essas teorias para podermos, no futuro, complementá-las e contribuir com o conhecimento científico. 
4.2.9 - Análises diferentes de evidências iguais podem gerar teorias diferentes uma vez que cada grupo pode ter se focado em um aspecto diferente (que pode não ter sido percebido pelo outro grupo); dessa maneira, nascem teorias que divergem provenientes de um mesmo material.

4.2.10 - Sim, criatividade e imaginação são necessárias durante investigações científicas, pois todos os dados nunca irão reproduzir um cenário preciso e idêntico ao real; ambas são utilizadas após a coleta de dados podendo, dessa maneira "fechar" o caso com descrição do acontecimento (como, por exemplo no caso dos dinossauros em que os mesmo dados geram cenários diferentes).

4.2.11 - Em certos momentos, como em períodos históricos, a ciência reflete tais valores devido aos grupos que detém o poder na época (como na Idade Média em que a igreja o controlava de acordo com a bíblia) já em algumas horas ela é universal (como algumas vezes é, hoje, em pesquisas de astronomia).

\section{Aluno 5 - Primeira etapa)}

5.1.6 - a) As leis científicas regem o funcionamento de um ciência, possibilitando a criação de teorias científicas, por exemplo a lei da gravitação universal dos corpos, que possibilitou diversas teorias no mundo da física.

5.1.7 - b1) As teorias mudam pois existe a constante descoberta de fatos que podem contradizer o conhecimento estabelecido. b2) Para entender o mundo em que vivemos e um dia encontrar todas as respostas para nossos problemas científicos, é a evolução da ciência. Apenas através da mutação das teorias científicas que hoje podemos usufruir de diversas tecnologias, como a eletricidade, etc.

5.1.9 - Conclusões diferentes são formuladas quando os dados são insuficientes para se comprovar definitivamente uma teoria.

5.1.10 - a) A criatividade e imaginação são essenciais nas etapas em que a exatidão é obrigatória, como coleta de dados.

5.1.11 - b) A ciência, na minha opinião, trabalha com fatos, sem que haja a possibilidade de relativização.

\section{Aluno 5 - Segunda etapa}

5.2.6 - a) Sim, basicamente, teorias são afirmações acerca de um fenômeno, para sua explicação, que podem se mostrarem falsas sem desestruturar todo um segmento do conhecimento científico, ao contrário das leis, que são 
afirmações entendidas como universais e obrigatórias e sua contestação implica numa alteração de todo um ramo do conhecimento científico, isto é, um quebra de paradigma, como ocorreu como ocorreu com a proposição da Relatividade de Einstein.

5.2.7 - b1) As teorias mudam pois precisam se adaptar com as descobertas científicas que implicam em sua replicação. b2) Para o aperfeiçoamento do saber, a mudança de uma teoria é uma evolução para a ciência e para entendermos o funcionamento do mundo.

5.2.9 - Diferentes conclusões são possíveis pois os dados disponíveis não são suficientes para rejeitar uma delas (ou comprovar outra).

5.2.10 - a) Os cientistas utilizam sua imaginação e criatividade após a coleta dos dados, para a formulação de teoria, o projeto e a coleta de dados devem ser o mais objetivo possível para não haver equívocos na produção da teoria. A imaginação e a criatividade são necessárias na criação de teorias pois as mesmas não são fatos concretos, são obra do pensamento humano.

5.2.11 - a) Acredito que o objetivo da ciência é a universalidade, entretanto não é isso que ocorre, a ciência é feita por seres humanos e, dependendo dos valores culturais, nosso modo de pensar é diferente.

\section{Aluno 6 - Primeira etapa}

6.1.6 - a) Sim, elas se diferenciam em seus pesos, suas comprovações, ou seja, uma lei científica é muito mais aceita que uma teoria científica. Na física podemos separar as leis de Newton das teorias das cordas.

6.1.7 - b1) As teorias mudam a partir do momento em que novos conhecimentos são adquiridos, com isso, as teorias são aprimoradas. b2) Muitas teorias científicas são a base para adquirir e melhorar novos conhecimentos, ou seja, sem essa base não é possível uma evolução da ciência.

6.1.9 - Isso é possível, pois os dois grupos de cientistas não tem uma precisão muito grande dos fatos tendo uma diferença de tempo muito grande entre os fatos é possível qualquer uma das hipóteses.

6.1.10 - a) Sim, principalmente no projeto e planejamento. A imaginação e criatividade facilita o desenvolvimento das teorias científicas como em exemplo as teorias de Darwin.

6.1.11 - a) A ciência reflete valores sociais e culturais porque ela é muito pouco acessível, sem contar em países onde ela é totalmente abolida pela religião. 


\section{Aluno 6 - Segunda etapa}

6.2.6 - a) Sim, pois a teoria científica não é de consenso universal enquanto as leis científicas estão inseridas no senso comum.

6.2.7 - b1) As teorias sempre mudam porque o desenvolver da ciência cabe em aperfeiçoar cada teoria, modificando-a. b2) As teorias científicas são apresentadas para serem questionadas e para ser aperfeiçoada.

6.2.9 - Isso é possível pois muitas vezes, as informações encontradas por serem muito antigas são passíveis de múltiplas interpretações sendo que muitas vezes uma interpretação é uma consequência da outra.

6.2.10 - a) Sim a imaginação e criatividade são usadas em todos os estágios das investigações pois muitas vezes nem tudo que é estudado é passível de uso dos sentidos e é nesse momento que há o uso da imaginação e da criatividade. Um exemplo seria a idealização da estrutura do DNA de Watson e Crieg.

6.2.11 - a) A ciência busca um lado universal, sem influências, porém grande parte dela é afetada pelos sistemas sociais e valores culturais pois muitas vezes ela é projetada com intuito e olhar de uma única cultura. Um exemplo seria estudos que são proibidos em determinada região, mais permitidos em outra.

\section{Aluno 7 - Primeira etapa}

7.1.6 - Sim, lei científica penso que é uma ordem a cumprir, ou seja, não pode ser mudado já teoria científica podem ser mudadas, um exemplo de lei científica é a lei de Mendel que todos têm que cumprir!!

7.1.7 - Sim, elas podem mudar porque não é uma certeza, mais sim uma maneira de tentar explicar os fatos. b) Porque precisamos obter conhecimento.

7.1.9 - Penso que cada grupo teve opiniões diferentes, ou seja, a sua, teorias dependem do ponto de vista de cada um.

7.1.10 - Sim, os cientistas usam sua imaginação e criatividade porque penso que é uma maneira de explicar quando não conseguem encontrar algumas respostas dos seus experimentos.

7.1.11 - Acredito que a ciência é universal porque todo mundo precisa obter conhecimento. Um bom exemplo disso é que quando nos formamos temos muita mais chance de arranjar um bom emprego do que a pessoa que não é formada. Então a ciência é também uma maneira de aprender. 


\section{Aluno 7 - Segunda etapa}

7.2.6 - Sim, a teoria abrange o universo como, por exemplo, a teoria celular, já as leis são mais específicas, como a lei de Newton, que é mais utilizada na física!...

7.2.7 - Elas mudam, porque em ciência nunca teremos certeza de estarmos certos, nossas teorias são para falsear nossos argumentos e as teorias mudam até que outros cientistas tenham a capacidade de refutar a ideia da teoria préexistente.

7.2.9 - Talvez, eles tiveram conclusões diferentes porque cada um usa, sua imaginação para poder explicar dados da natureza.

7.2.10 - Os cientistas utilizam sua criatividade e imaginação para poderem explicar as suas hipóteses que depois podem ou não ser refutada. Um bom exemplo disso é Morgan que utilizava sua criatividade e imaginação para explicar a mosca da banana.

7.2.11 - Penso que a ciência é universal, porque todos nós estamos preocupados com a nossa saúde penso que se não existe ciência, não saberemos como diagnosticar as doenças e provavelmente não saberíamos a cura, a ciência tem feito várias descobertas no mundo científico que acredito que tais descobertas beneficia toda a humanidade. Um bom exemplo são as células tronco que tem ajudado gente em todo mundo!

\section{Aluno 8 - Primeira etapa}

8.1.6 - Há diferença, pois uma teoria tem como base uma observação resultando em uma hipótese, já uma lei tem evidências que sustentam, comprovam a hipótese.

8.1.7 - b1) As teorias mudam uma vez que a forma como são vistas mudam e surgem novas interpretações. b2) As teorias mudam exatamente porque as aprendemos, possibilitando o surgimento de novos pontos de vista e opiniões. Pode-se usar como exemplo, a teoria dos átomos, diversos modelos forma imaginados por diferentes cientistas até chegar ao modelo atual.

8.1.9 - As conclusões diferentes são possíveis pelas diferentes formas de se interpretar dados, o que resulta em opiniões divergentes.

8.1.10 - Os cientistas usam a criatividade e imaginação em todos os estágios de investigação, pois é assim que pode chegar a hipóteses e teorias. 
8.1.11 - A ciência reflete valores sociais e culturais, é a partir desses valores que parte das perguntas que a ciência tenta responder surgem, como a origem da vida. Além de limitar certas pesquisas, como no caso das células-tronco.

\section{Aluno 8 - Segunda etapa}

8.2.6 - Sim, Leis científicas são como paradigmas, portanto que influenciam outras teorias.

8.2.7 - Sim, as teorias mudam, pois eventualmente surgem novos pontos de vista e interpretações sobre o assunto. Conhecer as teorias científicas é o que permite que surjam novas interpretações que eventualmente podem mudá-la.

8.2.9 - As conclusões diferentes são possíveis, pois a interpretação dos dados é variável e não é possível retroceder no tempo para verificar o que ocorreu.

8.2.10 - Sim, após a coleta de dados, no memento de elaboração de hipóteses e de que formas testá-las, como reproduzir determinado evento.

8.2.11 - A ciência é desenvolvida por pessoas, cada um com suas interpretações sobre diversos assuntos e eventos, que por sua vez são influenciados por valores. Por exemplo, a Biologia possui o paradigma da Evolução, ao pesquisar sobre determinado organismo, recorre-se a Teoria da Evolução para explicar como ele pode ter adquirido certos mecanismos.

\section{Aluno 9 - Primeira etapa}

9.1.6 - Teoria é uma hipótese que ainda não se tem certeza, já lei é algo imutável e de que se tem certeza. Como exemplo podemos citar a lei de Newton sobre ação e reação - observável no dia-a-dia - e a teoria do surgimento da vida - algo que aconteceu a muito tempo que não se tem total conhecimento.

9.1.7 - As teorias científicas podem mudar conforme se descobre uma hipótese não aplicável, ou alguma outra aplicável que complemente a teoria, já que a teoria é incerta e em constante processo de comprovação. É importante aprendermos teorias para entendermos linhas de raciocínio e o que se tem do conhecimento até então.

9.1.9 - Algo que aconteceu há muito tempo com muitas evidências, mas sem certezas.

9.1.10 - Sim, utilizam sua criatividade ao juntar as evidências para se formar uma linha de raciocínio. 
9.1.11 - Eu acredito que a ciência reflita valores sociais quanto ao que se pesquisa e a forma da mesma, porém é universal nos fatos descobertos.

\section{Aluno 9 - Segunda etapa}

9.2.6 - Sim. Leis, em geral, em teorias e exemplos matemáticos e experimentos. Já teoria são independentes de experimentos, podem ser deduções e induções.

9.2.7 - As teorias podem mudar, por que surgem novas teorias mais abrangentes e tão ou mais plausíveis que são mais aceitas pela comunidade científica. Podem surgir outras que não são excluídas, porém são menos aceitas pela comunidade científica. Preocupamos-nos em aprender teorias científicas para aprender várias linhas de pensamento sobre o mesmo assunto, já que não temos certeza de nenhuma. Por exemplo, a teoria de que a vida na terra e a que ela surgiu em outro lugar do cosmos.

9.2.9 - Pois os interpretaram e os conectaram de formas diferentes.

9.2.10 - Sim, os cientistas utilizam imaginação na hora de interpretar e ligar as evidências.

9.2.11 - Sim. Por exemplo, há mais pesquisas e investimento em áreas de interesse humano e isso reflete um valor cultural/político.

\section{Aluno 10 - Primeira etapa}

10.1.6 - Sim, porque a teoria, como diz o nome, é uma suposição. A lei científica pode ser provada experimentalmente. Exemplos: lei dos cossenos e a teoria de Bronsted-Lowry.

10.1.7 - b1) As teorias mudam porque novas coisas são descobertas e estudadas. b2) Teorias científicas atuais apesar de mudarem, são a base para as teorias do futuro. Darwin defendia a seleção natural e a variabilidade em uma espécie, porém não sabia explicar essa variabilidade. Com o desenvolvimento da genética o Darwinismo evoluiu, e o Neodarwinismo explica a variabilidade genética.

10.1.9 - Os dados utilizados pelos cientistas podem, por exemplo indicar que houve abalos físicos na Terra, morte de muitos dinossauros ao mesmo tempo, carbonização de animais e vegetais, etc. Daí, os cientistas formulam uma explicação científica que englobe ao máximo todos os dados estudados. 
10.1.10 - Sim, durante o projeto e planejamento e após a coleta de dados. Como dito na questão anterior, a criação de situações e hipóteses que englobem os dados coletados requer um pouco de imaginação.

10.1.11 - A ciência, como todo o resto do mundo, não é imparcial. Ela é feita pelos homens que possuem diferentes características e formações individuais, que farão parte da construção de suas hipóteses e teorias.

\section{Aluno 10 - Segunda etapa}

10.2.6 - Sim. Uma teoria é feita em cima de uma base teórica previamente acumulada e pode ser derrubada. A lei é algo que é verificado constantemente, e pode ser reformulada.

10.2.7 - Sim. b1) Novas descobertas não feitas. b) Porque é somente a partir da teoria pronta que poderemos entender a própria. O próprio modelo atômico é um exemplo.

10.2.9 - a) As evidências encontradas possibilitam o direcionamento para esses dois lados.

10.2.10 - Sim, após a coleta de dados. Na organização dos dados e posterior proposta de discussão dos resultados. Lei de Mendel.

10.2.11 - a) Porque toda ciência é feita por homens, e nós nunca somos completamente coniventes ou imparciais. Nossos valores culturais e de aprendizado sempre irão interferir em nossas reflexões.

\section{Aluno 11 - Primeira etapa}

11.1.6 - a) Sim, porque o primeiro é uma suposição enquanto a segunda já foi testada.

11.1.7 - b1) Porque novos fatos são experimentados e quanto maior o número de pesquisas, mais precisa se torna a teoria científica alvo. Alguns experimentos podem contradizer outros anteriores. b2) $\mathrm{O}$ nosso entendimento de mundo pode partir de um conhecimento adquirido e conforme teorias mudam, fica mais fácil interpretá-las pelo que já aprendemos. Exemplo: A teoria da evolução de Lamarck.

11.1.9 - Um conjunto de dados pode ser interpretado de formas diferentes.

11.1.10 - a) Após a coleta de dados.

11.1.11 - a) Porque a ciência exige interpretações de dados. 


\section{Aluno 11 - Segunda etapa}

11.2.6 - a) Porque Lei tem confiabilidade maior que teoria.

11.2.7 - b1) Porque os estudos não param. b2) Precisamos aprender 0 raciocínio que levou os cientistas às conclusões para podermos desenvolver nossos projetos futuramente a partir dos estudos anteriores, que servirão de base.

\subsection{9 - Imaginação.}

\subsubsection{0 - projeto e planejamento}

11.2.11 - a) Porque a ciência necessita de investimento e os cientistas podem escolher problemas a abordar que os beneficiem de alguma forma.

\section{Aluno 12 - Primeira etapa}

12.1.6 - Sim. Uma teoria ainda não passou por fase de experimentação, diferentemente da lei, que é comprovada. As leis de Newton, por exemplo, foram testadas e constituem assim verdades.

12.1.7 - Sim, a teoria pode transformar-se. As teorias podem transformar-se pois o conhecimento humano ainda é pequeno se comparado ao que se é capaz de observar no universo, em que não há verdade absoluta. Desse modo, sempre em busca dessa verdade, a busca pela verdade nos faz querer entender teorias, mesmo que elas mudem.

12.1.9 - Essas duas hipóteses geram o mesmo material de estudo, como vem do fogo e lava, não podendo assim, dar certeza do que ocorreu com os dinossauros.

12.1.10 - É totalmente necessário que cientistas se utilizem da imaginação durante suas investigações, pois para a formulação de novas teorias, tem que tomar rumos diferentes das já tomadas anteriormente.

12.1.11 - A ciência é universal, pois independente dos valores culturais, ela continua a avançar, sem modificar drasticamente valores culturais.

\section{Aluno 12 - Segunda etapa}

12.2.6 - Sim. Pois uma teoria científica não foi comprovada através de experimentos para se tornar uma evidência científica.

12.2.7 - Sim. Pois, como no exemplo, não havia estudos nem tecnologia suficiente para afirmar a teoria (de evolução), que sofreu várias mudanças até 
o momento. b) Preocupamos em compreender as teorias para que possamos ver se há caminho para que se torne uma lei, seja procurando falhas ou indo mais a fundo no assunto.

12.2.9 - Porque possivelmente os dados abrem possibilidade às conclusões diferentes.

12.2.10 - Sim. Mas utilizam a criatividade com critério, se baseando em conceitos científicos já testados e que são adaptáveis às investigações.

12.2.11 - A ciência é universal, pois as leis que regem a natureza é a mesma. Apenas é praticada de diferentes formas nos países, pois sofre influência de valores sociais, mas estes não a regulam.

\section{Aluno 13 - Primeira etapa}

13.1.6 - Sim, porque uma teoria científica ainda não foi concretamente provada nem aceita por outros cientistas.

13.1.7 - Sim, tudo, até as leis mais absolutas, podem mudar. b) As teorias mudam porque nosso conhecimento aumenta e com isso a possibilidade de conhecer a verdade sobre as coisas que considerávamos certas. É importante aprende-las mesmo assim para conhecermos as bases da informação e desenvolvimento sempre mais.

13.1.9 - A partir de um mesmo dado é possível chegar a conclusões diferentes de acordo com o que é sua especialidade, se um teólogo retrógrado se utilizar dos dados precursores das atuais teorias, ele pode dizer que a extinção foi causada pela chuva. Isso se evidencia por se tratar de um período tão distante.

13.1.10 - Sim, imaginação é peça chave no projeto e planejamento já que é necessário ter algo para buscar para que se consiga provar se está correto ou não e porque. Depois, somente dados embasados corretamente podem ser utilizados.

13.1.11 - Acredito que a ciência seja universal mas que a maioria dos cientistas, não. As pessoas são influenciadas mas as descobertas comprovadas não podem ser negadas, de forma que umas completam as outras, tornando a ciência uma peça única e universal.

\section{Aluno 13 - Segunda etapa}

13.2.6 - a) Sim, uma teoria é algo mais abrangente, mas menos específico e uma lei é algo muito mais concreto e fácil de se comprovar. 
13.2.7 - Sim, as teorias mudam ou podem mudar. A tecnologia é um grande aliado da ciência e o seu avanço nos ajuda a descobrir coisas novas, de forma que uma teoria só é correta até provarem o contrário. Preocupamos-nos em aprendê-las porque a partir da base chegamos ao cume, logo, precisamos saber "o que" procurar para conseguirmos testá-las.

13.2.9 - A análise dos dados (qualquer que sejam eles) nos permite enxergar melhor o que se passou, mas jamais contar uma história 100\% certa, logo, munidos do mesmo material, cientistas chegaram a duas conclusões plausíveis mas que não são exclusivas. Logo, analise de dados pode sim ser ambíguo.

13.2.10 - Sim. Os cientistas utilizam criatividade em todos os estágios já que é preciso decidir como será a coleta de dados e depois, como explicar os resultados. Por exemplo, se queremos saber se uma característica é genética ou não, precisamos também escolher uma maneira de obtê-la e/ou explicá-la para o caso de não ser genético.

13.2.11 - Sim é afetado por valores próprios. Por exemplo, porque não temos clones humanos ainda? Porque a maioria dos países ainda não trabalha $\mathrm{c} /$ células-tronco? Porque a "célula artificial" está gerando polêmica? Porque o mundo está impregnado de falsos valores morais que podem ou não ser também regionais.

\section{Aluno 14 - Primeira etapa}

14.1.6 - Uma lei provavelmente é aceita de forma quase unânime pela comunidade científica, enquanto uma teoria ainda necessita de mais experimentação.

14.1.7 - As teorias mudam pois dependem de experimentação. Ainda assim é valido estuda-las para compreender alguns processos que são abordados por ela.

14.1.9 - As conclusões diferentes são possíveis uma vez que nenhum dos formuladores das hipóteses estava presente quando ocorriam os fatos. Deste modo, diferentes explicações para os vestígios geram diferentes hipóteses.

14.1.10 - Eles usam a criatividade no projeto e planejamento. Após levantar uma hipótese, buscam evidências que procuram prová-la.

14.1.11 - A ciência reflete os valores culturais e científicos da época, pois já foi utilizada para "provar" a teoria geocêntrica, por exemplo, quando os pesquisadores estavam inseridos em um contexto dominante da Igreja Católica. 
14.2.6 - Sim, as leis geralmente se aplicam a um número maior de eventos, foram mais testadas.

14.2.7 - As teorias mudam pois com o passar do tempo obtemos cada vez mais precisão nos resultados. Mesmo assim ainda é válido aprender as teorias pois elas explicam, mesmo que parcialmente, fenômenos.

14.2.9 - As conclusões diferem, pois cada autor considera um conjunto de fatores como fundamental para corroborar sua hipótese.

14.2.10 - Usam a criatividade para o projeto e planejamento de suas investigações, uma vez que ele pode estar lidando com algo que ele não conhece bem. Por exemplo: um pesquisador não conhece bem todos os passos de uma via metabólica, mas analisando produtos finais, pode imaginar como usam seus precedentes.

14.2.11 - A ciência reflete valores sociais e culturais. Em países onde a religião é presente, ainda, muito fortemente na política, existem barreiras como, por exemplo, o uso ou não de células-tronco.

\section{Aluno 15 - Primeira etapa}

15.1.6 - a) Sim. Acho que há diferença, pois a lei científica é uma teoria que conseguiu ser comprovada através de experimentos, como leis da física de refração e reflexão por exemplo.

15.1.7 - b1) Sim, podem se transformar. As teorias mudam com o tempo graças ao aperfeiçoamento de técnicas e experimentos, comprovando ou anulando certas teorias. b2) Nos preocupamos em aprender as teorias, pois queremos entender certos fenômenos por ela explicados e procuramos a verdade acerca delas. Um exemplo é a teoria do surgimento do universo.

15.1.9 - A formulação de duas hipóteses diferentes decorre também das diferentes crenças entre os dois grupos de cientistas, que interpretaram os dados de forma diferente.

15.1.10 - a) Acredito que eles usem criatividade e imaginação no início da elaboração das questões, durante o resto do trabalho se apoiam em dados e experimentos.

15.1.11 - b) Acredito que a ciência deveria ser algo universal, todos os países em todo mundo devem ter acesso aos mesmos dados e conhecimentos, comprovados por experiências formando verdades quase absolutas.

\section{Aluno 15 - Segunda etapa}


15.2.6 - Sim, lei científica já foi uma teoria. Após a realização de diversos experimentos foram criados limites para a explicação da teoria moldando-a em uma lei científica. Um exemplo é a lei de Mendel, que não é validado para qualquer cruzamento.

15.2.7 - b1) As teorias mudam na medida em que experimentos mostram que elas não se aplicam a certas situações. Para exemplificar isso a teoria é modificada. b2) Aprendemos as teorias justamente para podermos acompanhar o desenvolvimento do conhecimento científico ao longo do tempo.

15.2.9 - As hipóteses são criadas a partir do pensamento do homem, levando em conta muitas vezes opiniões próprias. Testes de hipóteses dão força a uma ou outra hipótese.

15.2.10 - a) Eles usam a imaginação e criatividade pautadas em conhecimentos adquiridos por eles, no estágio investigativo após à coleta dos dados, a fim de explicar o que foi observado.

15.2.11 - b) A ciência começou refletindo valores culturais, mas hoje ela se tornou praticamente universal. A produção do conhecimento científico torna-se padrão em todo o mundo, pautada na matemática. Artigos publicados por cientistas brasileiros são reconhecidos e utilizados por cientistas de várias partes do mundo.

\section{Aluno 16 - Primeira etapa}

16.1.6 - Sim, há diferença, a teoria científica não é uma certeza absoluta, como a teoria da evolução que sempre algo novo é descoberto e pode mudar essa teoria, já a lei científica é um fato provado a partir de experimentos que não pode ser refeita.

16.1.7 - Sim, pois com o aparecimento de novos fatos, novas provas que podem mudar essa teoria, mesmo assim devemos aprendê-las para termos 0 conhecimento necessário e por no momento ser a verdade como também para analisarmos o porque mudou e o pensamento anterior.

16.1.9 - É provável que os dois grupos de cientistas tenham usado diferentes dados para poderem chegar à conclusões diferentes.

16.1.10 - Os cientistas utilizam criatividade e imaginação no projeto, para que eles possam formular sua teoria ou lei, indo mais a fundo em coisas que outras pessoas não pensaram.

16.1.11 - Quando a ciência nasceu, ela era baseada em valores sociais, políticos e religiosos, mas agora ela é universal, sendo a mesma para todos. 


\section{Aluno 16 - Segunda etapa}

16.2.6 - Sim, a teoria é um estudo que não pode ser provado, que pode mudar a qualquer hora se aparecer uma teoria mais provável, já a lei científica é baseada em fatos reais e muito difícil de ser mudada.

16.2.7 - A teoria pode mudar pelo fato delas não serem verdade baseada em fatos comprovados e sim, a partir de um estudo, elas serem formuladas de forma que seja parecida com o que realmente aconteceu, mas sem certezas. Nós estudamos essas teorias pois elas são importantes, apesar de estarem erradas ou poderem mudar, pois é com elas que podemos estudar e talvez provar uma teoria, como as teorias da evolução de Lamarck e Darwin.

16.2.9 - Como o mesmo conjunto de dados não pode ser provado, pois ocorreu há muito tempo, as conclusões tiradas sobre eles podem ser variadas, foi o que ocorreu nesse caso.

16.2.10 - Os cientistas usam a imaginação na hora de formular um projeto apenas, depois o resto se baseia nos fatos estudados.

16.2.11 - A ciência é universal, pois nela não são colocados sentimentos nem religiões, é tudo baseado num estudo e em fatos, não havendo diferença se for estudada em qualquer lugar ou religião.

\section{Aluno 17 - Primeira etapa}

17.1.6 - Não. Teorias científicas são enunciados elaborados a partir de hipóteses comprovadas por experimentos tal como são as leis. Entretanto, leis científicas podem ser refutadas tanto por apresentação de novos fatos como por outros experimentos (entenda-se lei $=$ teoria).

17.1.7 - Toda teoria científica é passível de mudança. Seja pela apresentação de um novo fato que desacredite a teoria ou por um experimento que a contradiga. Mesmo assim é necessário deter o conhecimento acerca das teorias atuais, tanto porque elas são a maior certeza que temos no momento do mundo que nos cerca como porque poderemos nós mesmos reformulá-las de maneira mais adequada se preciso. Um exemplo é a teoria do meteoro que aniquilou os dinossauros que teria caído na península de Yucatán. É perfeitamente possível que alguém, por meio de testes ou estudos fósseis, demonstre que o meteoro seria incapaz de fazer tal coisa, e acabe desenvolvendo a teoria de uma severa era glacial por meio de outros experimentos e fatos. 
17.1.9 - A interpretação dos dados, bem como os experimentos realizados, pode variar para os diferentes cientistas que os utilizam, principalmente se os dados são ambíguos e podem significar mais de uma informação. Não descartando ainda a possibilidade de ambos os eventos terem ocorrido.

\section{Aluno 17 - Segunda etapa}

17.2.6 - Sim, uma teoria deriva de uma série de testes realizados sobre uma hipótese que não foi refutada. Já uma lei é mais ampla, costuma explicar mais elementos que uma teoria e, por essa razão, uma lei pode surgir de um conjunto de teorias.

17.2.7 - Sim uma teoria pode transformar-se. Com o passar do tempo, descobre-se o limite da capacidade de dedução (ou previsão) de uma teoria, devido a descoberta de novos fatores, do desenvolvimento de tecnologias mais precisas, até que a lei necessite ser sobreposta por outra. A importância de se aprender as teorias atuais é não só compreender o mundo neste dado instante com o conhecimento cada vez mais para aumentar aquela compreensão, mesmo que derrubando antigas teorias para inserir novas. Um exemplo seria o surgimento da teoria evolucionista, que apareceu bem antes de Darwin, e antes de estar refinada "por completo" ainda sim foi um importante passo para quebrar o paradigma essencialista.

17.2.9 - Como o estudo foi feito a partir de evidências indiretas, é possível supor que haja mais de uma interpretação dessas evidências. Isto é, um mesmo conjunto de dados pode sugerir duas ou mais explicações.

17.2.10 - Sim, com certeza. Acredito que em todos os estágios de investigação o cientista utiliza de sua imaginação, embora uns, como o projeto e planejamento, abram mais margem a isso do que outros, como a coleta de dados.

17.2.11 - Sim, ela reflete. Porque quem faz a ciência são os homens, e estes estão sujeitos às inclinações sociais e culturais de suas épocas. $O$ modo como reflete pode ser desde direcionamento de pesquisa, estudos nucleares em países em constante estado de guerra, até a completa moldagem de uma teoria, como Hitler que acreditava na eugenia e realizava testes nesse sentido. 
Anexo 8: Tabulação das respostas dos alunos - questionário VOSE

ALUNO 18.1

\begin{tabular}{|l|l|}
\hline & Resposta \\
\hline 2A & CP \\
\hline 2B & CP \\
\hline 2C & I \\
\hline 2D & CP \\
\hline 3A & CP \\
\hline 3B & CT \\
\hline 3C & DP \\
\hline 3D & DP \\
\hline 3E & I \\
\hline 4A & I \\
\hline 4B & DP \\
\hline 4C & I \\
\hline 7A & CT \\
\hline 7B & CP \\
\hline 7C & CP \\
\hline 7D & I \\
\hline 8A & CP \\
\hline 8C & CP \\
\hline 15D & CT \\
\hline 15E & I \\
\hline 15H & CT \\
\hline 15I & CT \\
\hline
\end{tabular}

ALUNO 18.2

\begin{tabular}{|l|l|}
\hline & Resposta \\
\hline 2A & CT \\
\hline 2B & CT \\
\hline 2C & DT \\
\hline 2D & DP \\
\hline 3A & CP \\
\hline 3B & CT \\
\hline 3C & DP \\
\hline 3D & I \\
\hline 3E & DP \\
\hline 4A & CT \\
\hline 4B & CP \\
\hline 4C & CP \\
\hline 7A & DP \\
\hline 7B & CP \\
\hline 7C & CP \\
\hline
\end{tabular}

\begin{tabular}{|l|l|}
\hline $7 D$ & I \\
\hline $8 \mathrm{~A}$ & CP \\
\hline $8 \mathrm{C}$ & DT \\
\hline $15 \mathrm{D}$ & CT \\
\hline $15 \mathrm{E}$ & CP \\
\hline $15 \mathrm{H}$ & CT \\
\hline $15 \mathrm{I}$ & $\mathrm{CT}$ \\
\hline
\end{tabular}

ALUNO 19.1

\begin{tabular}{|l|l|}
\hline & Resposta \\
\hline 2A & CP \\
\hline 2B & CP \\
\hline 2C & I \\
\hline 2D & I \\
\hline 3A & CP \\
\hline 3B & CP \\
\hline 3C & DT \\
\hline 3D & CP \\
\hline 3E & I \\
\hline 4A & I \\
\hline 4B & DP \\
\hline 4C & DP \\
\hline 7A & DP \\
\hline 7B & CP \\
\hline 7C & CP \\
\hline 7D & DP \\
\hline 8A & CP \\
\hline 8C & CP \\
\hline 15D & CT \\
\hline 15E & I \\
\hline 15H & CP \\
\hline 15I & CP \\
\hline & \\
\hline
\end{tabular}

ALUNO 19.2

\begin{tabular}{|l|l|}
\hline & Resposta \\
\hline 2A & CP \\
\hline 2B & I \\
\hline 2C & DT \\
\hline 2D & DT \\
\hline 3A & DP \\
\hline 3B & I \\
\hline
\end{tabular}




\begin{tabular}{|l|l|}
\hline $3 C$ & I \\
\hline $3 D$ & CP \\
\hline $3 E$ & CP \\
\hline $4 A$ & I \\
\hline $4 B$ & DP \\
\hline $4 C$ & I \\
\hline $7 A$ & CP \\
\hline $7 B$ & I \\
\hline $7 C$ & DP \\
\hline $7 D$ & CP \\
\hline $8 A$ & CP \\
\hline $8 C$ & I \\
\hline $15 D$ & CP \\
\hline $15 E$ & I \\
\hline $15 H$ & CP \\
\hline $15 I$ & CP \\
\hline
\end{tabular}

\begin{tabular}{|l|l|}
\hline $2 C$ & $C P$ \\
\hline $2 D$ & $C P$ \\
\hline $3 A$ & $C P$ \\
\hline $3 B$ & $C P$ \\
\hline $3 C$ & DP \\
\hline $3 D$ & DP \\
\hline $3 E$ & DT \\
\hline $4 A$ & $C P$ \\
\hline $4 B$ & $C P$ \\
\hline $4 C$ & $C P$ \\
\hline $8 A$ & $C P$ \\
\hline $8 C$ & $C P$ \\
\hline $15 D$ & $C T$ \\
\hline $15 E$ & $C P$ \\
\hline $15 H$ & $C T$ \\
\hline $15 I$ & $C P$ \\
\hline
\end{tabular}

ALUNO 20.1

ALUNO 21.1

\begin{tabular}{|l|l|}
\hline & Resposta \\
\hline 2A & CP \\
\hline 2B & CP \\
\hline 2C & DT \\
\hline 2D & DP \\
\hline 3A & CP \\
\hline 3B & CP \\
\hline 3C & DP \\
\hline 3D & CP \\
\hline 3E & DP \\
\hline 4A & DP \\
\hline 4B & DP \\
\hline 4C & DP \\
\hline 7A & CP \\
\hline 7B & CP \\
\hline 7C & DP \\
\hline 7D & DP \\
\hline 8A & CP \\
\hline 8C & DP \\
\hline 15D & CT \\
\hline 15E & DP \\
\hline 15H & CP \\
\hline 15I & CP \\
\hline & \\
\hline
\end{tabular}

\begin{tabular}{|l|l|}
\hline & Resposta \\
\hline 2A & CT \\
\hline 2B & CT \\
\hline 2C & DP \\
\hline 2D & CP \\
\hline 3A & CP \\
\hline 3B & CT \\
\hline 3C & DP \\
\hline 3D & DT \\
\hline 3E & CP \\
\hline 4A & I \\
\hline 4B & DT \\
\hline 4C & CT \\
\hline 7A & CT \\
\hline 7B & CP \\
\hline 7C & I \\
\hline 7D & DP \\
\hline 8A & DT \\
\hline 8C & DP \\
\hline 15D & CT \\
\hline 15E & DP \\
\hline 15H & CP \\
\hline 15I & CT \\
\hline
\end{tabular}

ALUNO 20.2

\begin{tabular}{|l|l|}
\hline & Resposta \\
\hline 2A & CT \\
\hline 2B & CT \\
\hline
\end{tabular}

ALUNO 21.2

\begin{tabular}{|l|l|}
\hline & Resposta \\
\hline $2 \mathrm{~A}$ & CT \\
\hline
\end{tabular}




\begin{tabular}{|l|l|}
\hline 2B & CT \\
\hline 2C & DP \\
\hline 2D & DP \\
\hline 3A & CT \\
\hline 3B & CT \\
\hline 3C & DP \\
\hline 3D & DT \\
\hline 3E & DP \\
\hline 4A & CP \\
\hline 4B & CP \\
\hline 4C & DP \\
\hline 7A & CT \\
\hline 7B & CT \\
\hline 7C & DP \\
\hline 7D & DP \\
\hline 8A & DP \\
\hline 8C & DP \\
\hline 15D & I \\
\hline 15E & I \\
\hline 15G & I \\
\hline 15H & I \\
\hline 15I & I \\
\hline
\end{tabular}

\begin{tabular}{|l|l|}
\hline 2A & CT \\
\hline 2B & CT \\
\hline 2C & DT \\
\hline 2D & DP \\
\hline 3A & CP \\
\hline 3B & CT \\
\hline 3C & DT \\
\hline 3D & DT \\
\hline 3E & DT \\
\hline 4A & CP \\
\hline 4B & DP \\
\hline 4C & DP \\
\hline 7A & DT \\
\hline 7B & I \\
\hline 7C & I \\
\hline 7D & CT \\
\hline 8A & I \\
\hline 8C & I \\
\hline 15D & CT \\
\hline 15E & DT \\
\hline 15H & CP \\
\hline 15I & CP \\
\hline
\end{tabular}

\section{ALUNO 22.1}

\section{ALUNO 23.1}

\begin{tabular}{|l|l|}
\hline & Resposta \\
\hline $2 A$ & CT \\
\hline $2 B$ & CT \\
\hline $2 C$ & CP \\
\hline $2 D$ & CP \\
\hline $3 A$ & CP \\
\hline $3 B$ & CP \\
\hline $3 C$ & DP \\
\hline $3 D$ & DP \\
\hline $3 E$ & CP \\
\hline $4 A$ & CP \\
\hline $4 B$ & CP \\
\hline $4 C$ & DP \\
\hline $8 A$ & I \\
\hline $8 C$ & CP \\
\hline $15 D$ & CT \\
\hline $15 E$ & DT \\
\hline $15 H$ & CP \\
\hline $15 I$ & CP \\
\hline
\end{tabular}

ALUNO 22.2

\begin{tabular}{|l|l|}
\hline & Resposta \\
\hline 2A & CT \\
\hline 2B & CT \\
\hline 2C & DP \\
\hline 2D & CP \\
\hline 3A & DP \\
\hline 3B & CT \\
\hline 3C & DP \\
\hline 3D & DT \\
\hline 3E & CP \\
\hline 4A & CP \\
\hline 4B & DT \\
\hline 4C & DP \\
\hline 7A & CP \\
\hline 7B & CP \\
\hline 7C & DT \\
\hline 7D & CP \\
\hline 8A & DT \\
\hline 8C & DP \\
\hline 15D & CT \\
\hline 15E & DP \\
\hline 15H & CT \\
\hline 15I & DP \\
\hline
\end{tabular}


ALUNO 23.2

\begin{tabular}{|l|l|}
\hline & Resposta \\
\hline 2A & CT \\
\hline 2B & CT \\
\hline 2C & DT \\
\hline 2D & CP \\
\hline 3A & CT \\
\hline 3B & CT \\
\hline 3C & DP \\
\hline 3D & DT \\
\hline 3E & DP \\
\hline 4A & CP \\
\hline 4B & DT \\
\hline 4C & DT \\
\hline 7A & DP \\
\hline 7B & DP \\
\hline 7C & DP \\
\hline 7D & CP \\
\hline 8A & DP \\
\hline 8C & CP \\
\hline 15D & CT \\
\hline 15E & DT \\
\hline 15H & CP \\
\hline 15I & CT \\
\hline
\end{tabular}

ALUNO 24.1

\begin{tabular}{|l|l|}
\hline & Resposta \\
\hline 2A & CP \\
\hline 2B & CP \\
\hline 2C & DT \\
\hline 2D & DP \\
\hline 3A & I \\
\hline 3B & CP \\
\hline 3C & DT \\
\hline 3D & DP \\
\hline 3E & I \\
\hline 4A & CP \\
\hline 4B & DP \\
\hline 4C & DP \\
\hline 7A & DT \\
\hline 7B & CT \\
\hline 7C & DP \\
\hline 7D & I \\
\hline 8A & CP \\
\hline 8C & DT \\
\hline
\end{tabular}

\begin{tabular}{|l|l|}
\hline $15 \mathrm{D}$ & $\mathrm{CT}$ \\
\hline $15 \mathrm{E}$ & $\mathrm{DP}$ \\
\hline $15 \mathrm{H}$ & $\mathrm{CP}$ \\
\hline $15 \mathrm{I}$ & $\mathrm{CP}$ \\
\hline
\end{tabular}

ALUNO 24.2

\begin{tabular}{|l|l|}
\hline & Resposta \\
\hline 2A & CT \\
\hline 2B & CT \\
\hline 2C & DT \\
\hline 2D & DT \\
\hline 3A & CP \\
\hline 3B & CT \\
\hline 3C & DP \\
\hline 3D & DT \\
\hline 3E & DP \\
\hline 4A & CT \\
\hline 4B & DT \\
\hline 4C & CP \\
\hline 7A & CT \\
\hline 7B & CP \\
\hline 7C & DP \\
\hline 7D & I \\
\hline 8A & CP \\
\hline 8C & DT \\
\hline 15D & CT \\
\hline 15E & CP \\
\hline 15H & CP \\
\hline 15I & CP \\
\hline
\end{tabular}

ALUNO 25.1

\begin{tabular}{|l|l|}
\hline & Resposta \\
\hline 2A & CT \\
\hline 2B & CP \\
\hline 2C & I \\
\hline 2D & CP \\
\hline 3A & CP \\
\hline 3B & CP \\
\hline 3C & I \\
\hline 3D & I \\
\hline 3E & DT \\
\hline 4A & I \\
\hline 4B & DT \\
\hline 4C & CP \\
\hline 7A & CT \\
\hline 7B & CT \\
\hline
\end{tabular}




\begin{tabular}{|l|l|}
\hline $7 C$ & $C P$ \\
\hline $7 D$ & DT \\
\hline $8 A$ & $C P$ \\
\hline $8 C$ & $C P$ \\
\hline $15 D$ & $C T$ \\
\hline $15 E$ & $C P$ \\
\hline $15 H$ & $C P$ \\
\hline $15 I$ & $C P$ \\
\hline
\end{tabular}

ALUNO 25.2

\begin{tabular}{|l|l|}
\hline & Resposta \\
\hline 2A & CT \\
\hline 2B & CP \\
\hline 2C & CP \\
\hline 2D & I \\
\hline 3A & CP \\
\hline 3B & CP \\
\hline 3C & DT \\
\hline 3D & DT \\
\hline 3E & DT \\
\hline 4A & CT \\
\hline 4B & CP \\
\hline 4C & CP \\
\hline 7A & CP \\
\hline 7B & CP \\
\hline 7C & CT \\
\hline 7D & DT \\
\hline 8A & I \\
\hline 8C & CP \\
\hline 15D & CP \\
\hline 15E & DP \\
\hline 15H & DP \\
\hline 15I & CT \\
\hline
\end{tabular}

ALUNO 26.1

\begin{tabular}{|l|l|}
\hline & Resposta \\
\hline 2A & CP \\
\hline 2B & DP \\
\hline 2C & DP \\
\hline 2D & DP \\
\hline 3A & CP \\
\hline 3B & CT \\
\hline 3C & DT \\
\hline 3D & CP \\
\hline 3E & DP \\
\hline 4A & CP \\
\hline
\end{tabular}

\begin{tabular}{|l|l|}
\hline 4B & CP \\
\hline 4C & CP \\
\hline 7A & CP \\
\hline 7B & CP \\
\hline 7C & CP \\
\hline 7D & DT \\
\hline $8 A$ & DP \\
\hline $8 C$ & DT \\
\hline $15 D$ & CT \\
\hline $15 E$ & DP \\
\hline $15 H$ & CP \\
\hline $15 I$ & CP \\
\hline
\end{tabular}

ALUNO 26.2

\begin{tabular}{|l|l|}
\hline & Resposta \\
\hline 2A & CT \\
\hline 2B & CP \\
\hline 2C & DT \\
\hline 2D & DP \\
\hline 3A & CT \\
\hline 3B & CP \\
\hline 3C & DP \\
\hline 3D & DP \\
\hline 3E & DP \\
\hline 4A & CP \\
\hline 4B & CP \\
\hline 4C & CP \\
\hline 7A & CP \\
\hline 7B & DP \\
\hline 7C & CP \\
\hline 7D & I \\
\hline 8A & CP \\
\hline 8C & DT \\
\hline 15D & CP \\
\hline 15E & DP \\
\hline 15H & CP \\
\hline 15I & CT \\
\hline & \\
\hline
\end{tabular}

ALUNO 27.1

\begin{tabular}{|l|l|}
\hline & Resposta \\
\hline 2A & DT \\
\hline 2B & DP \\
\hline 2C & DT \\
\hline 2D & DP \\
\hline 3A & CP \\
\hline 3B & CP \\
\hline
\end{tabular}




\begin{tabular}{|l|l|}
\hline $3 C$ & DP \\
\hline $3 D$ & DP \\
\hline $3 E$ & DP \\
\hline $4 A$ & CP \\
\hline $4 B$ & DP \\
\hline $4 C$ & CP \\
\hline $7 A$ & $C P$ \\
\hline $7 B$ & $C T$ \\
\hline $7 C$ & DT \\
\hline $7 D$ & DT \\
\hline $8 A$ & DP \\
\hline $8 C$ & CP \\
\hline $15 D$ & CP \\
\hline $15 E$ & DP \\
\hline $15 H$ & $C P$ \\
\hline $15 I$ & CP \\
\hline
\end{tabular}

ALUNO 27.2

\begin{tabular}{|l|l|}
\hline & Resposta \\
\hline 2A & CT \\
\hline 2B & CP \\
\hline 2C & DT \\
\hline 2D & DP \\
\hline 3A & CP \\
\hline 3B & CP \\
\hline 3C & DT \\
\hline 3D & DP \\
\hline 3E & DT \\
\hline 4A & DT \\
\hline 4B & DP \\
\hline 4C & CP \\
\hline 7A & CP \\
\hline 7B & CP \\
\hline 7C & DP \\
\hline 7D & CP \\
\hline 8A & DT \\
\hline 8C & CP \\
\hline 15D & CT \\
\hline 15E & DT \\
\hline 15H & CP \\
\hline 15I & CP \\
\hline
\end{tabular}

ALUNO 28.1

\begin{tabular}{|l|l|}
\hline & Resposta \\
\hline 2A & CP \\
\hline 2B & CP \\
\hline
\end{tabular}

\begin{tabular}{|l|l|}
\hline 2C & CP \\
\hline 2D & I \\
\hline 3A & CP \\
\hline $3 B$ & CP \\
\hline 3C & CP \\
\hline 3D & I \\
\hline $3 E$ & I \\
\hline 4A & CP \\
\hline $4 B$ & CP \\
\hline 4C & CP \\
\hline 7A & CT \\
\hline 7B & CT \\
\hline 7C & I \\
\hline 7D & DP \\
\hline 8A & CP \\
\hline 8C & CT \\
\hline 15D & CT \\
\hline 15E & DP \\
\hline 15H & CP \\
\hline 15I & I \\
\hline
\end{tabular}

ALUNO 28.2

\begin{tabular}{|l|l|}
\hline & Resposta \\
\hline 2A & I \\
\hline 2B & I \\
\hline 2C & CP \\
\hline 2D & CT \\
\hline 3A & CP \\
\hline 3B & CT \\
\hline 3C & DP \\
\hline 3D & I \\
\hline 3E & I \\
\hline 4A & CP \\
\hline 4B & CP \\
\hline 4C & CP \\
\hline 7A & CP \\
\hline 7B & CP \\
\hline 7C & CP \\
\hline 7D & I \\
\hline 8A & CP \\
\hline 8C & CP \\
\hline 15D & CT \\
\hline 15E & CP \\
\hline 15H & CP \\
\hline 15I & DP \\
\hline & \\
\hline
\end{tabular}


ALUNO 29.1

\begin{tabular}{|l|l|}
\hline & Resposta \\
\hline 2A & CT \\
\hline 2B & CT \\
\hline 2C & DT \\
\hline 2D & CP \\
\hline 3A & CP \\
\hline 3B & CT \\
\hline 3C & DT \\
\hline 3D & DT \\
\hline 3E & DT \\
\hline 4A & CP \\
\hline 4B & DT \\
\hline 4C & DP \\
\hline 7A & CP \\
\hline 7B & DT \\
\hline 7C & CT \\
\hline 7D & CP \\
\hline 8A & CP \\
\hline 8C & DP \\
\hline 15D & CT \\
\hline 15E & DP \\
\hline 15H & I \\
\hline 15I & CT \\
\hline
\end{tabular}

ALUNO 29.2

\begin{tabular}{|l|l|}
\hline & Resposta \\
\hline 2A & CT \\
\hline 2B & CT \\
\hline 2C & DT \\
\hline 2D & DT \\
\hline 3A & CP \\
\hline 3B & CT \\
\hline 3C & DT \\
\hline 3D & I \\
\hline 3E & DT \\
\hline 4A & CP \\
\hline 4B & CP \\
\hline 4C & CP \\
\hline 7A & CT \\
\hline 7B & I \\
\hline 7C & DT \\
\hline 7D & I \\
\hline 8A & DT \\
\hline 8C & DT \\
\hline
\end{tabular}

\begin{tabular}{|l|l|}
\hline $15 \mathrm{D}$ & CT \\
\hline $15 \mathrm{E}$ & DT \\
\hline $15 \mathrm{H}$ & $\mathrm{I}$ \\
\hline $15 \mathrm{I}$ & CT \\
\hline
\end{tabular}

ALUNO 30.1

\begin{tabular}{|l|l|}
\hline & Resposta \\
\hline 2A & CP \\
\hline 2B & CP \\
\hline 2C & DP \\
\hline 2D & DT \\
\hline 3A & CP \\
\hline 3B & CT \\
\hline 3C & DT \\
\hline 3D & CT \\
\hline 3E & I \\
\hline 4A & CT \\
\hline 4B & CT \\
\hline 4C & CP \\
\hline 7A & CT \\
\hline 7B & CT \\
\hline 7C & I \\
\hline 7D & DT \\
\hline 8A & CP \\
\hline 8C & CP \\
\hline 15D & CT \\
\hline 15E & DP \\
\hline 15H & I \\
\hline 15I & CT \\
\hline
\end{tabular}

ALUNO 30.2

\begin{tabular}{|l|l|}
\hline & Resposta \\
\hline 2A & CP \\
\hline 2B & I \\
\hline 2C & CP \\
\hline 2D & CP \\
\hline 3A & CP \\
\hline 3B & CT \\
\hline 3C & DT \\
\hline 3D & CP \\
\hline 3E & DT \\
\hline 4A & CP \\
\hline 4B & CP \\
\hline 4C & CP \\
\hline 7A & CP \\
\hline 7B & CT \\
\hline
\end{tabular}




\begin{tabular}{|l|l|}
\hline $7 C$ & $C T$ \\
\hline $7 D$ & DT \\
\hline $8 \mathrm{~A}$ & DP \\
\hline $8 \mathrm{C}$ & CP \\
\hline $15 \mathrm{D}$ & $\mathrm{CT}$ \\
\hline $15 \mathrm{E}$ & $\mathrm{I}$ \\
\hline $15 \mathrm{H}$ & $\mathrm{CP}$ \\
\hline $15 \mathrm{I}$ & $\mathrm{CT}$ \\
\hline
\end{tabular}

ALUNO 31.1

\begin{tabular}{|l|l|}
\hline & Resposta \\
\hline 2A & CP \\
\hline 2B & CP \\
\hline 2C & I \\
\hline 2D & CP \\
\hline 3A & CP \\
\hline 3B & CP \\
\hline 3C & I \\
\hline 3D & DP \\
\hline 3E & I \\
\hline 4A & DT \\
\hline 4B & CP \\
\hline 4C & DT \\
\hline 7A & DP \\
\hline 7B & I \\
\hline 7C & I \\
\hline 7D & DP \\
\hline 8A & DP \\
\hline 8C & DP \\
\hline 15D & CT \\
\hline 15E & DT \\
\hline 15H & CP \\
\hline 15I & CP \\
\hline
\end{tabular}

ALUNO 31.2

\begin{tabular}{|l|l|}
\hline & Resposta \\
\hline 2A & CP \\
\hline 2B & CP \\
\hline 2C & DT \\
\hline 2D & CP \\
\hline 3A & DP \\
\hline 3B & CP \\
\hline 3C & DP \\
\hline 3D & I \\
\hline 3E & CP \\
\hline 4A & DT \\
\hline
\end{tabular}

\begin{tabular}{|l|l|}
\hline 4B & CT \\
\hline 4C & DT \\
\hline 7A & DT \\
\hline 7B & DT \\
\hline 7C & I \\
\hline 7D & CT \\
\hline 8A & DT \\
\hline 8C & CP \\
\hline 15D & CT \\
\hline 15E & DT \\
\hline 15H & I \\
\hline 15I & I \\
\hline
\end{tabular}

ALUNO 32.1

\begin{tabular}{|l|l|}
\hline & Resposta \\
\hline 2A & CP \\
\hline 2B & CT \\
\hline 2C & DT \\
\hline 2D & DT \\
\hline 3A & CP \\
\hline 3B & CP \\
\hline 3C & DT \\
\hline 3D & DP \\
\hline 3E & DT \\
\hline 4A & DT \\
\hline 4B & CT \\
\hline 4C & DT \\
\hline 7A & DT \\
\hline 7B & DT \\
\hline 7C & CT \\
\hline 7D & DT \\
\hline 8A & DP \\
\hline 8C & DT \\
\hline 15D & CT \\
\hline 15E & DT \\
\hline 15H & CP \\
\hline 15I & CT \\
\hline
\end{tabular}

ALUNO 32.2

\begin{tabular}{|l|l|}
\hline & Resposta \\
\hline 2A & CT \\
\hline 2B & CT \\
\hline 2C & DT \\
\hline 2D & DT \\
\hline 3A & CP \\
\hline 3B & CT \\
\hline
\end{tabular}




\begin{tabular}{|l|l|}
\hline $3 C$ & DT \\
\hline $3 D$ & CP \\
\hline $3 E$ & CP \\
\hline $4 A$ & DP \\
\hline $4 B$ & CP \\
\hline $4 C$ & CP \\
\hline $7 A$ & DT \\
\hline $7 B$ & DT \\
\hline $7 C$ & $C T$ \\
\hline $7 D$ & DP \\
\hline $8 A$ & DP \\
\hline $8 C$ & CP \\
\hline $15 D$ & $C T$ \\
\hline $15 E$ & DP \\
\hline $15 H$ & $C T$ \\
\hline $15 I$ & $C T$ \\
\hline
\end{tabular}

ALUNO 33.1

\begin{tabular}{|l|l|}
\hline & Resposta \\
\hline 2A & CT \\
\hline 2B & CT \\
\hline 2C & DP \\
\hline 2D & DP \\
\hline 3A & DT \\
\hline 3B & CP \\
\hline 3C & DP \\
\hline 3D & DP \\
\hline 3E & DP \\
\hline 4A & CP \\
\hline 4B & CP \\
\hline 4C & CP \\
\hline 7A & I \\
\hline 7B & CP \\
\hline 7C & I \\
\hline 7D & I \\
\hline 8A & DP \\
\hline 8C & DP \\
\hline 15D & CP \\
\hline 15E & DP \\
\hline 15H & DP \\
\hline 15I & DP \\
\hline
\end{tabular}

ALUNO 33.2

\begin{tabular}{|l|l|}
\hline & Resposta \\
\hline 2A & CT \\
\hline 2B & CT \\
\hline
\end{tabular}

\begin{tabular}{|l|l|}
\hline 2C & DP \\
\hline 2D & CP \\
\hline 3A & CP \\
\hline 3B & CT \\
\hline 3C & DT \\
\hline 3D & CP \\
\hline 3E & DP \\
\hline 4A & CP \\
\hline 4B & DP \\
\hline 4C & DP \\
\hline 7A & DT \\
\hline 7B & CP \\
\hline 7C & CP \\
\hline 7D & DT \\
\hline 8A & CP \\
\hline 8C & DP \\
\hline 15D & CT \\
\hline 15E & CT \\
\hline 15H & DP \\
\hline 15I & DP \\
\hline
\end{tabular}

ALUNO 34.1

\begin{tabular}{|l|l|}
\hline & Resposta \\
\hline 2A & DP \\
\hline 2B & DT \\
\hline 2C & CP \\
\hline 2D & CT \\
\hline 3A & CT \\
\hline 3B & CP \\
\hline 3C & DT \\
\hline 3D & DT \\
\hline 3E & DT \\
\hline 4A & DP \\
\hline 4B & CP \\
\hline 4C & DP \\
\hline 7A & DT \\
\hline 7B & DT \\
\hline 7C & CP \\
\hline 7D & CP \\
\hline 8A & CP \\
\hline 8C & CP \\
\hline 15D & CT \\
\hline 15E & DP \\
\hline 15H & CP \\
\hline 15I & CP \\
\hline
\end{tabular}


ALUNO 34.2

\begin{tabular}{|l|l|}
\hline & Resposta \\
\hline 2A & DP \\
\hline 2B & DT \\
\hline 2C & CT \\
\hline 2D & CT \\
\hline 3A & DP \\
\hline 3B & DP \\
\hline 3C & CP \\
\hline 3D & I \\
\hline 3E & CP \\
\hline 4A & I \\
\hline 4B & DP \\
\hline 4C & CP \\
\hline 7A & DP \\
\hline 7B & CT \\
\hline 7C & DP \\
\hline 7D & I \\
\hline 8A & DT \\
\hline 8C & CP \\
\hline 15D & CT \\
\hline 15E & CT \\
\hline 15H & DP \\
\hline 15I & I \\
\hline
\end{tabular}

ALUNO 35.1

\begin{tabular}{|l|l|}
\hline & Resposta \\
\hline 2A & I \\
\hline 2B & I \\
\hline 2C & I \\
\hline 2D & I \\
\hline 3A & DP \\
\hline 3B & I \\
\hline 3C & I \\
\hline 3D & CP \\
\hline 3E & CP \\
\hline 4A & CP \\
\hline 4B & CP \\
\hline 4C & DP \\
\hline 7A & CT \\
\hline 7B & I \\
\hline 7C & DP \\
\hline 7D & DT \\
\hline 8A & DT \\
\hline 8C & CP \\
\hline
\end{tabular}

\begin{tabular}{|l|l|}
\hline $15 \mathrm{D}$ & I \\
\hline $15 \mathrm{E}$ & DP \\
\hline $15 \mathrm{H}$ & CP \\
\hline $15 \mathrm{I}$ & CP \\
\hline
\end{tabular}

ALUNO 35.2

\begin{tabular}{|l|l|}
\hline & Resposta \\
\hline 2A & CP \\
\hline 2B & CP \\
\hline 2C & DP \\
\hline 2D & CP \\
\hline 3A & DP \\
\hline 3B & CP \\
\hline 3C & DP \\
\hline 3D & CP \\
\hline 3E & DP \\
\hline 4A & CP \\
\hline 4B & DP \\
\hline 4C & CT \\
\hline 7A & CP \\
\hline 7B & CT \\
\hline 7C & I \\
\hline 7D & DP \\
\hline 8A & CT \\
\hline 8C & DP \\
\hline 15D & CP \\
\hline 15E & CP \\
\hline 15H & CP \\
\hline 15I & CT \\
\hline
\end{tabular}

ALUNO 36.1

\begin{tabular}{|l|l|}
\hline & Resposta \\
\hline 2A & CT \\
\hline 2B & CP \\
\hline 2C & DP \\
\hline 2D & DT \\
\hline 3A & DT \\
\hline 3B & CT \\
\hline 3C & DP \\
\hline 3D & DT \\
\hline 3E & I \\
\hline 4A & CP \\
\hline 4B & DP \\
\hline 4C & CP \\
\hline 7A & DT \\
\hline 7B & CP \\
\hline
\end{tabular}




\begin{tabular}{|l|l|}
\hline $7 C$ & CT \\
\hline $7 D$ & I \\
\hline $8 \mathrm{~A}$ & CT \\
\hline $8 \mathrm{C}$ & I \\
\hline $15 \mathrm{D}$ & CT \\
\hline $15 \mathrm{E}$ & DT \\
\hline $15 \mathrm{H}$ & DP \\
\hline $15 \mathrm{I}$ & DP \\
\hline
\end{tabular}

ALUNO 36.2

\begin{tabular}{|l|l|}
\hline & Resposta \\
\hline 2A & CT \\
\hline 2B & CP \\
\hline 2C & DP \\
\hline 2D & DT \\
\hline 3A & I \\
\hline 3B & CP \\
\hline 3C & DP \\
\hline 3D & DT \\
\hline 3E & DP \\
\hline 4A & I \\
\hline 4B & I \\
\hline 4C & I \\
\hline 7A & DT \\
\hline 7B & DP \\
\hline 7C & CP \\
\hline 7D & CT \\
\hline 8A & CP \\
\hline 8C & DP \\
\hline 15D & CT \\
\hline 15E & DP \\
\hline 15H & DT \\
\hline 15I & DP \\
\hline
\end{tabular}

ALUNO 37.1

\begin{tabular}{|l|l|}
\hline & Resposta \\
\hline 2A & CP \\
\hline 2B & CP \\
\hline 2C & DT \\
\hline 2D & DP \\
\hline 3A & I \\
\hline 3B & CP \\
\hline 3C & DP \\
\hline 3D & I \\
\hline 3E & DP \\
\hline 4A & CP \\
\hline
\end{tabular}

\begin{tabular}{|l|l|}
\hline 4B & DP \\
\hline 4C & I \\
\hline 7A & CP \\
\hline 7B & CP \\
\hline 7C & DP \\
\hline 7D & DP \\
\hline $8 A$ & I \\
\hline $8 C$ & CP \\
\hline $15 D$ & CT \\
\hline $15 E$ & DP \\
\hline $15 H$ & CP \\
\hline $15 I$ & I \\
\hline
\end{tabular}

ALUNO 37.2

\begin{tabular}{|l|l|}
\hline & Resposta \\
\hline 2A & CP \\
\hline 2B & CT \\
\hline 2C & DT \\
\hline 2D & DP \\
\hline 3A & CP \\
\hline 3B & CT \\
\hline 3C & DT \\
\hline 3D & I \\
\hline 3E & DP \\
\hline 4A & CT \\
\hline 4B & DT \\
\hline 4C & DP \\
\hline 7A & I \\
\hline 7B & I \\
\hline 7C & I \\
\hline 7D & I \\
\hline 8A & DP \\
\hline 8C & CP \\
\hline 15D & CT \\
\hline 15E & I \\
\hline 15H & CP \\
\hline 15I & CT \\
\hline & \\
\hline
\end{tabular}

ALUNO 38.1

\begin{tabular}{|l|l|}
\hline & Resposta \\
\hline 2A & DT \\
\hline 2B & DP \\
\hline 2C & CP \\
\hline 2D & CT \\
\hline 3A & CT \\
\hline 3B & CT \\
\hline
\end{tabular}




\begin{tabular}{|l|l|}
\hline $3 C$ & $D T$ \\
\hline $3 D$ & DP \\
\hline $3 E$ & DP \\
\hline $4 A$ & CP \\
\hline $4 B$ & DT \\
\hline $4 C$ & DP \\
\hline $7 A$ & CP \\
\hline $7 B$ & CP \\
\hline $7 C$ & I \\
\hline $7 D$ & DP \\
\hline $8 A$ & CT \\
\hline $8 C$ & DP \\
\hline $15 D$ & CT \\
\hline $15 E$ & I \\
\hline $15 H$ & CP \\
\hline $15 I$ & DP \\
\hline
\end{tabular}

ALUNO 38.2

\begin{tabular}{|l|l|}
\hline & Resposta \\
\hline 2A & DP \\
\hline 2B & DP \\
\hline 2C & CP \\
\hline 2D & CP \\
\hline 3A & CT \\
\hline 3B & CP \\
\hline 3C & DT \\
\hline 3D & CT \\
\hline 3E & DT \\
\hline 4A & CP \\
\hline 4B & DT \\
\hline 4C & DP \\
\hline 7A & DP \\
\hline 7B & DP \\
\hline 7C & CP \\
\hline 7D & CT \\
\hline 8A & CP \\
\hline 8C & DP \\
\hline 15D & CT \\
\hline 15E & DP \\
\hline 15H & CP \\
\hline 15I & DT \\
\hline
\end{tabular}

ALUNO 39.1

\begin{tabular}{|l|l|}
\hline & Resposta \\
\hline 2A & CP \\
\hline 2B & CT \\
\hline
\end{tabular}

\begin{tabular}{|l|l|}
\hline 2C & DP \\
\hline 2D & CP \\
\hline 3A & I \\
\hline 3B & CP \\
\hline 3C & CP \\
\hline 3D & DP \\
\hline 3E & I \\
\hline 4A & DT \\
\hline 4B & CP \\
\hline 4C & DP \\
\hline 7A & CT \\
\hline 7B & DP \\
\hline 7C & DP \\
\hline 7D & DP \\
\hline 8A & CP \\
\hline 8C & I \\
\hline 15D & CP \\
\hline 15E & DP \\
\hline 15H & I \\
\hline 15I & CT \\
\hline
\end{tabular}

ALUNO 39.2

\begin{tabular}{|l|l|}
\hline & Resposta \\
\hline 2A & CP \\
\hline 2B & CT \\
\hline 2C & DP \\
\hline 2D & CP \\
\hline 3A & DP \\
\hline 3B & CT \\
\hline 3C & DP \\
\hline 3D & I \\
\hline 3E & DP \\
\hline 4A & I \\
\hline 4B & DP \\
\hline 4C & CP \\
\hline 7A & CP \\
\hline 7B & I \\
\hline 7C & CP \\
\hline 7D & I \\
\hline 8A & CP \\
\hline 8C & CP \\
\hline 15D & CP \\
\hline 15E & CP \\
\hline 15H & CP \\
\hline 15I & CT \\
\hline
\end{tabular}


ALUNO 40.1

\begin{tabular}{|l|l|}
\hline & Resposta \\
\hline 2A & CP \\
\hline 2B & CP \\
\hline 2C & DP \\
\hline 2D & DP \\
\hline 3A & DP \\
\hline 3B & CP \\
\hline 3C & DP \\
\hline 3D & CP \\
\hline 3E & DT \\
\hline 4A & CP \\
\hline 4B & DP \\
\hline 4C & DT \\
\hline 7A & CP \\
\hline 7B & DP \\
\hline 7C & DP \\
\hline 7D & DT \\
\hline 8A & DT \\
\hline 8C & DT \\
\hline 15D & DP \\
\hline 15E & DP \\
\hline 15H & DP \\
\hline 15I & DP \\
\hline
\end{tabular}

ALUNO 40.2

\begin{tabular}{|l|l|}
\hline & Resposta \\
\hline 2A & CT \\
\hline 2B & CT \\
\hline 2C & DT \\
\hline 2D & DT \\
\hline 3A & CP \\
\hline 3B & CT \\
\hline 3C & DT \\
\hline 3D & DP \\
\hline 3E & DT \\
\hline 4A & CP \\
\hline 4B & CP \\
\hline 4C & CP \\
\hline 7A & CT \\
\hline 7B & CP \\
\hline 7C & I \\
\hline 7D & I \\
\hline 8A & DT \\
\hline 8C & CP \\
\hline
\end{tabular}

\begin{tabular}{|l|l|}
\hline $15 \mathrm{D}$ & $\mathrm{CT}$ \\
\hline $15 \mathrm{E}$ & $\mathrm{DT}$ \\
\hline $15 \mathrm{H}$ & $\mathrm{CP}$ \\
\hline $15 \mathrm{I}$ & $\mathrm{CP}$ \\
\hline
\end{tabular}

ALUNO 41.1

\begin{tabular}{|l|l|}
\hline & Resposta \\
\hline 2A & CT \\
\hline 2B & CT \\
\hline 2C & I \\
\hline 2D & I \\
\hline 3A & CP \\
\hline 3B & CT \\
\hline 3C & DT \\
\hline 3D & I \\
\hline 3E & DP \\
\hline 4A & DP \\
\hline 4B & DP \\
\hline 4C & CP \\
\hline 7A & CP \\
\hline 7B & CT \\
\hline 7C & I \\
\hline 7D & I \\
\hline 8A & CP \\
\hline 8C & I \\
\hline 15D & CT \\
\hline 15E & DP \\
\hline 15H & CP \\
\hline 15I & CP \\
\hline & \\
\hline
\end{tabular}

ALUNO 41.2

\begin{tabular}{|l|l|}
\hline & Resposta \\
\hline 2A & CT \\
\hline 2B & CP \\
\hline 2C & DP \\
\hline 2D & DP \\
\hline 3A & CP \\
\hline 3B & CT \\
\hline 3C & DT \\
\hline 3D & DP \\
\hline 3E & DT \\
\hline 4A & CP \\
\hline 4B & DP \\
\hline 4C & DP \\
\hline 7A & CP \\
\hline 7B & CT \\
\hline
\end{tabular}




\begin{tabular}{|l|l|}
\hline $7 C$ & DT \\
\hline $7 D$ & I \\
\hline $8 \mathrm{~A}$ & DP \\
\hline $8 \mathrm{C}$ & CP \\
\hline $15 \mathrm{D}$ & CT \\
\hline $15 \mathrm{E}$ & CP \\
\hline $15 \mathrm{H}$ & CT \\
\hline $15 \mathrm{I}$ & CT \\
\hline
\end{tabular}

\begin{tabular}{|l|l|}
\hline $4 B$ & $D P$ \\
\hline $4 C$ & $C P$ \\
\hline $8 A$ & DP \\
\hline $8 C$ & $C P$ \\
\hline $15 D$ & $C T$ \\
\hline $15 E$ & $C T$ \\
\hline $15 H$ & $C P$ \\
\hline $15 I$ & $C P$ \\
\hline
\end{tabular}

ALUNO 42.1

ALUNO 43.1

\begin{tabular}{|l|l|}
\hline & Resposta \\
\hline 2A & DP \\
\hline 2B & DT \\
\hline 2C & CP \\
\hline 2D & CT \\
\hline 3A & CT \\
\hline 3B & CT \\
\hline 3C & DP \\
\hline 3D & DP \\
\hline 3E & DT \\
\hline 4A & I \\
\hline 4B & DT \\
\hline 4C & I \\
\hline 7A & I \\
\hline 7B & I \\
\hline 7C & CP \\
\hline 7D & DT \\
\hline 8A & DP \\
\hline 8C & CP \\
\hline 15D & CP \\
\hline 15E & CP \\
\hline 15H & DP \\
\hline 15I & DP \\
\hline
\end{tabular}

\begin{tabular}{|l|l|}
\hline & Resposta \\
\hline 2A & CP \\
\hline 2B & CP \\
\hline 2C & DP \\
\hline 2D & DT \\
\hline 3A & CP \\
\hline 3B & CT \\
\hline 3C & DT \\
\hline 3D & CP \\
\hline 3E & DT \\
\hline 4A & CP \\
\hline 4B & DP \\
\hline 4C & CP \\
\hline 7A & CP \\
\hline 7B & CT \\
\hline 7C & DP \\
\hline 7D & DT \\
\hline 8A & CP \\
\hline 8C & CP \\
\hline 15D & CT \\
\hline 15E & DT \\
\hline 15H & CT \\
\hline 15I & CT \\
\hline
\end{tabular}

ALUNO 42.2

ALUNO 43.2

\begin{tabular}{|l|l|}
\hline & Resposta \\
\hline 2A & CP \\
\hline 2B & DP \\
\hline 2C & DP \\
\hline 2D & DP \\
\hline 3A & DP \\
\hline 3B & CP \\
\hline 3C & DP \\
\hline 3D & DP \\
\hline 3E & DP \\
\hline 4A & I \\
\hline
\end{tabular}

\begin{tabular}{|l|l|}
\hline & Resposta \\
\hline 2A & CP \\
\hline 2B & CP \\
\hline 2C & CP \\
\hline 2D & CP \\
\hline 3A & DP \\
\hline 3B & CT \\
\hline 3C & DT \\
\hline 3D & DP \\
\hline 3E & DT \\
\hline 4A & DP \\
\hline
\end{tabular}




\begin{tabular}{|l|l|}
\hline 4B & DP \\
\hline 4C & CP \\
\hline 7A & CP \\
\hline 7B & CT \\
\hline 7C & CP \\
\hline 7D & DT \\
\hline $8 A$ & CP \\
\hline $8 C$ & CP \\
\hline $15 D$ & CT \\
\hline $15 E$ & DT \\
\hline $15 H$ & CT \\
\hline $15 I$ & CT \\
\hline
\end{tabular}

ALUNO 44.1

\begin{tabular}{|l|l|}
\hline & Resposta \\
\hline 2A & CP \\
\hline 2B & CP \\
\hline 2C & DT \\
\hline 2D & DT \\
\hline 3A & CT \\
\hline 3B & CP \\
\hline 3C & DT \\
\hline 3D & DP \\
\hline 3E & DT \\
\hline 4A & DP \\
\hline 4B & DP \\
\hline 4C & CP \\
\hline 7A & DP \\
\hline 7B & CT \\
\hline 7C & I \\
\hline 7D & DT \\
\hline 8A & CP \\
\hline 8C & DT \\
\hline 15D & CP \\
\hline 15E & DP \\
\hline 15H & CT \\
\hline 15I & CT \\
\hline & \\
\hline
\end{tabular}

ALUNO 44.2

\begin{tabular}{|l|l|}
\hline & Resposta \\
\hline 2A & CT \\
\hline 2B & DP \\
\hline 2C & DT \\
\hline 2D & DT \\
\hline 3A & I \\
\hline 3B & CP \\
\hline
\end{tabular}

\begin{tabular}{|l|l|}
\hline $3 C$ & DT \\
\hline $3 D$ & CP \\
\hline $3 E$ & DT \\
\hline $4 A$ & I \\
\hline $4 B$ & DT \\
\hline $4 C$ & DP \\
\hline $7 A$ & CP \\
\hline $7 B$ & CP \\
\hline $7 C$ & CP \\
\hline $7 D$ & DT \\
\hline $8 A$ & DP \\
\hline $8 C$ & DT \\
\hline $15 D$ & CT \\
\hline $15 E$ & DT \\
\hline $15 H$ & CT \\
\hline $15 I$ & CT \\
\hline
\end{tabular}

ALUNO 45.1

\begin{tabular}{|l|l|}
\hline & Resposta \\
\hline 2A & CT \\
\hline 2B & CP \\
\hline 2C & DT \\
\hline 2D & DP \\
\hline 3A & DP \\
\hline 3B & CP \\
\hline 3C & DT \\
\hline 3D & DP \\
\hline 3E & DP \\
\hline 4A & CP \\
\hline 4B & DT \\
\hline 4C & DT \\
\hline 7A & CT \\
\hline 7B & CT \\
\hline 7C & I \\
\hline 7D & CP \\
\hline 8A & CP \\
\hline 8C & CP \\
\hline 15D & CT \\
\hline 15E & CP \\
\hline 15H & CP \\
\hline 15I & CT \\
\hline
\end{tabular}

ALUNO 45.2

\begin{tabular}{|l|l|}
\hline & Resposta \\
\hline 2A & CP \\
\hline 2B & CP \\
\hline
\end{tabular}




\begin{tabular}{|l|l|}
\hline 2C & DT \\
\hline 2D & CP \\
\hline 3A & CP \\
\hline 3B & CT \\
\hline 3C & DT \\
\hline 3D & DP \\
\hline 3E & DP \\
\hline 4A & CP \\
\hline 4B & CP \\
\hline 4C & DP \\
\hline 7A & CT \\
\hline 7B & CT \\
\hline
\end{tabular}

\begin{tabular}{|l|l|}
\hline $7 C$ & CP \\
\hline $7 D$ & DP \\
\hline $8 A$ & CP \\
\hline $8 C$ & CP \\
\hline $15 D$ & CT \\
\hline $15 E$ & DP \\
\hline $15 G$ & CP \\
\hline $15 H$ & CT \\
\hline $15 I$ & CT \\
\hline
\end{tabular}

